Fecha de recepción: abril 2021 Fecha de aprobación: mayo 2021 Fecha publicación: junio 2021

\section{Tesis de Doctorado en Diseño recomendada para su publicación. De lo Oculto a lo Legible Diseño de la Estética de los Concept cars. General Motors en Estados Unidos entre 1945 y $1965^{\star}$}

Claudia Marcela Sanchez ${ }^{(1)}$

\begin{abstract}
Resumen: De lo Oculto a lo Legible en el Diseño de la Estética de los Concept Cars GM en Estados Unidos entre 1945 y 1965 es una investigación de enfoque cualitativo que estudia la praxis de los diseñadores desde la caracterización de su hacer, pensar y producto para hacer legible cómo se produce el diseño de la estética del objeto y reflexionar la agencia de los diseñadores con relación a su contexto de operación. Enmarcada en la línea temática de Forma y Materialidad esta tesis combina material empírico y fenómenos como operaciones, ideas, personas, contextos, ideologías que describen diferentes puntos de entrada a la concepción de la estética del objeto para develar su multidimensionalidad. El anclaje de esta investigación es la praxis para el diseño de la estética del objeto en un estudio de caso cuyo recorte espacio temporal ofrece la posibilidad de deconstrucción no sólo de factores para las operaciones - productos, también la naturaleza relacional y performativa de este acto intencional de diseño desde la perspectiva institucional. Los Concept cars en su manifestación material en la serie de modelos entre 1945 y 1965 ofrecen heterogeneidades y continuidades que sirven para contrastar la adecuación entre la concepción de sus narrativas y el mensaje de la imagen del automóvil en su expresión de ficción y valor de identidad. Consideramos que los hallazgos de esta investigación son relevantes para reflexionar en las competencias del diseñador para fusionar en una expresión llamada forma una serie de contenidos que constituyen mensajes que conectan con la sensibilidad de las personas y con ello se advierte la responsabilidad social del acto de diseño de la estética del objeto.
\end{abstract}

Palabras clave: diseño - estética - relacional - performativo - praxis - diseñador.

[Resúmenes en inglés y portugués en las páginas 292-293]

(1) Claudia Sanchez, industrial designer, master's degree in education, professor with a doctorate in Design. I am a specialist in project management for the design and development of products, services, and systems with more than 20 years of experience in the conception and implementation of solutions for the corporate and academic fields.

* Versión resumida para difusión. La tesis doctoral completa está publicada en el sitio web de la Universidad de Palermo https://www.palermo.edu/dyc/doctorado_diseno/tesisdoc toral_sanchez.html 


\section{Introducción}

De lo Oculto a lo Legible en el Diseño de la Estética de los Concept Cars GM en Estados Unidos entre 1945 y 1965 es una investigación de enfoque cualitativo que estudia la praxis de los diseñadores desde la caracterización de su hacer, pensar y producto para hacer legible cómo se produce el diseño de la estética del objeto y reflexionar la agencia de los diseñadores con relación a su contexto de operación.

Enmarcada en la línea temática de Forma y Materialidad esta tesis combina material empírico y fenómenos como operaciones, ideas, personas, contextos, ideologías que describen diferentes puntos de entrada a la concepción de la estética del objeto para develar su multidimensionalidad. Al poner en relación las condiciones sociohistóricas de formación de las concepciones estéticas de la práctica como guía para la estructuración formal y el resultado obtenido en el cuerpo del automóvil se procura develar la sinergia que debe coexistir en los elementos compositivos del mensaje para la experiencia estética; la correspondencia entre la intención y lo concretado. Por último, promover la comprensión del rol del diseñador en un entorno que es condicionante y a la vez fuente de representaciones para la dimensión estética.

El anclaje de esta investigación es la praxis para el diseño de la estética del objeto en un estudio de caso cuyo recorte espacio temporal ofrece la posibilidad de deconstrucción no sólo de factores para las operaciones - productos, también la naturaleza relacional y performativa de este acto intencional de diseño desde la perspectiva institucional.

Estados Unidos entre 1945 y 1965, experimentó un momento de Segunda Posguerra Mundial en que celebraba su victoria con una situación económica y tecnológica que favoreció la aceleración de cambio políticos, sociales, de infraestructura y de dimensiones estéticas bajo el enfoque de un orgullo de nación que comandó la adhesión del individuo a la ideología del American Way Life como planteo disruptivo para marcar su diferencia con preceptos europeos y para promover los valores de democracia, libertad, progreso, supremacía americana que opone a cualquier manifestación de tipo comunista. La industria del automóvil contribuiría para alcanzar la promesa de un buen nivel de vida sustentado en el gusto por la vida material y con ello una sociedad orientada al consumo.

Se parte de 1945 momento de culminación de la guerra, como punto de inicio a una serie de transformaciones que ponen foco en el primer renglón económico e industrial de la nación: el automotriz. El automóvil representa un recurso de generación de empleo, el objeto aspiracional y de compensación de la clase trabajadora que se traduce en un medio de incentivo de la sociedad de consumo para la consolidación del capitalismo y para la sociedad en un medio de proyección social, de experimentación de la infraestructura de nación, de vida familiar y social.

Así que Estado y corporaciones se unen para promover nuevas dimensiones de atractivo a este objeto y la estética es del diseño de su apariencia es para la General Motors la vía para ganar visibilidad, aumentar sus ventas y marcar la vanguardia frente a su principal rival Ford que con respecto al Streamline como formas estéticas avaladas en las que se desenvolvieron los brillos y líneas del Art Decó mantiene su foco en el costo y facilidad de manufactura. 
Los años 50s son reconocidos como el periodo de oro de Estados Unidos como centro de innovación estética y tecnológica gracias a las corporaciones presentes, pero es la General Motors que en su programa Concept cars marca una nueva dirección en el diseño de la estética del automóvil; esta expresión alude a un automóvil concepto que propone una interpretación futurista en tanto vehículo y en tanto apariencia.

Se trata de una experiencia liderada por los diseñadores para el desarrollo paralelo a la línea comercial para la exploración de nuevas narrativas estéticas que aludan no a representaciones presentes sino imaginadas pero que se conecten con los valores de ideología institucionales, de Estado y de una concepción propia de los diseñadores de la General Motors que surge de una construcción estrecha con el contexto social y de la finalidad comercial.

Dentro de la época se reconoce la presencia de quienes representaban el funcionalismo como modelo de pensamiento formal, del surgimiento del racionalismo funcionalista en Europa con centro en la Hochshule fur Gelstaltum de la ciudad de Ulm y con quienes conviven en Estados Unidos como producto de la diáspora de la Bauhaus. Si bien se menciona que en el sector automotriz se adhiere al punto de vista ideológico, la Deitscher Werkbund apostó por la fusión entre el arte y la máquina promoviendo la industrialización con discusiones como la que versa entre belleza y función o las posibilidades de materialización sin detrimento de la naturaleza artística, esta visión fue más orientada al objeto de la vida cotidiana. Atravesados por el pragmatismo, en su orientación de acciones por la finalidad. También constituyó una mentalidad de realización de nuevas posibilidades y de resolver los problemas mientras se construye la experiencia. El pensar y hacer avanzaron en estrecha relación con el contexto; sujeto y contexto se configuran mutuamente.

Para los ejecutivos de la General Motors seguir lo que denominan viejas líneas de pensamiento es jugar sobre seguro cuando observan que a ese punto modelos de marcas como Chrysler, Ford y de la General Motors tienen apariencias similares con dominancia de líneas orgánicas, pero con ausencia de un carácter propio, distintivo que pueda conectar con los diferentes grupos de consumo que están promoviéndose. La participación de artistas, modelistas, empíricos y diseñadores formados en escuelas como Pratt Institute va a enriquecería la construcción progresiva del artefacto industrial con un sello propio estadounidense que se distinga del carácter estético del europeo; otras escalas y proporciones, profusión en los detalles, ficción y valor de identidad son algunas de sus concepciones.

Nos centramos en la praxis de los Concept cars de la General Motors por tratarse de una experiencia que transita desde la intencionalidad, la idea a su manifestación material en una serie de operaciones progresivas que se correlacionan con multiplicidad de factores. Una práctica que no es un ejercicio de libre imaginación, sino que requiere de una articulación compleja de significados y de la producción de una fusión que se traducirá en un mensaje para la conexión con los sujetos.

Los Concept cars en su manifestación material en la serie de modelos entre 1945 y 1965 ofrecen heterogeneidades y continuidades que sirven para contrastar la adecuación entre la concepción de sus narrativas y el mensaje de la imagen del automóvil en su expresión de ficción y valor de identidad. Para la sociedad estadounidense no sólo una manifestación material de un utilitario, también se trató de efectos inmateriales que aún prevalecen como parte de su patrimonio cultural. 
Con la puesta en diálogo esta práctica con saberes de las Humanidades indagamos esta construcción humana reconociendo lo espacio temporal; los acontecimientos, circunstancias, ideología, imaginarios, otros valores que van a alimentar la formación del pensamiento estético y también condicionarlo por el intercambio en doble vía: lo que capta el diseñador y devuelve como mensaje en la apariencia del producto; lo que el colectivo humano le retorna como respuesta de juicio del gusto o la mediación que el diseñador hace entre la finalidad institucional, lo que las personas encuentran para conectar con su sensibilidad y la voz del diseñador.

El escenario de la investigación liderada por las disciplinas formales en su perspectiva de valoración de las cualidades del objeto o desde el enfoque al receptor abrió para nosotros la oportunidad de una investigación desde el diseño que no estudia al Concept car o automóvil concepto como objeto constituido sino como acto de asimilación progresiva a partir del foco praxis como unidad de análisis central de esta redescripción que según Juan Samaja es el producto de la investigación científica al fragmentar un objeto de estudio en componentes esenciales para caracterizarlos desde fundamentos teóricos para develar sus atributos relevantes y sus relaciones. Nos comprometimos con el desarrollo de marco integrado de saberes complementarios que facultará suficiente cobertura conceptual para el estudio de las diferentes dimensiones de las variables.

Optamos por un enfoque cualitativo porque sus diferentes atributos de investigación nos permitieron ahondar en la naturaleza particular del fenómeno con métodos como el exploratorio, el descriptivo, la interpretación rigurosa guiada por los instrumentos conceptuales para develar causalidades y relaciones estructurales que den cuenta de la estructura interna de esta praxis, hallando que el diseño de la estética es de tipo relacional y performativo en tanto operaciones como en las narrativas que construye soportadas en la metáfora por su valor de expresión simbólica y que faculta tanto representaciones figurativas como de ficción. Esta concepción estética de los Concept cars es la representación de aquello que se conoce (referente) y de otra que excede lo presente, da cuenta de un carácter propio y es evocador para promover la fantasía (autorreferente).

Con la caracterización de este pensar, hacer y producto, pudimos develar una etapa de conceptualización previa a la figuración que se nutre de la estructuración de información que circula en el entorno en sus diferentes representaciones y que dispuesta de manera sistemática muestra dimensiones sociológico - discursivas (de contenidos ideológicos y condicionantes institucionales), referencial - expresivas (referentes, patrones, estereotipos de sociedad y de la cultura material), y de la experiencia estética (entre leyes compositivas y el mensaje de fantasía) que nutren la producción imaginativa para otorgar un sentido a la estructura formal procurando la conexión con la sociedad que la apreciará, en este caso en su concreción material automóvil.

$\mathrm{Al}$ seguir de manera diacrónica el fenómeno, pudo develarse la importancia de tomar del pasado para proyectar lo que aún no existe (el componente ficcional), en el presente. Este caso mostró una hibridación de lo precedente con referentes de otras categorías para producir conceptos de ficción que cobraran sentido en el presente. Con el estudio sincrónico pudieron explicarse las relaciones de diseño - contexto para configurarse mutuamente: pensamiento proyectual y lo que el diseño luego ofrece al contexto para facilitar su asociación. 
Con relación a la utilización del conocimiento, este trabajo aporta nociones y hallazgos que nutren el debate teórico y también sirve como una referencia del conocimiento que ha legado un equipo de diseñadores con desafíos equiparables a los de la realidad actual: la concepción formal en su dimensión estética, sus ejes inmaterial y material con relación a los modos de su experimentación en contexto.

Consideramos que los hallazgos de esta investigación son relevantes para reflexionar en las competencias del diseñador para fusionar en una expresión llamada forma una serie de contenidos que constituyen mensajes que conectan con la sensibilidad de las personas y con ello se advierte la responsabilidad social del acto de diseño de la estética del objeto. En el plano cognitivo del proyecto, los aportes de este trabajo ofrecen instrumentos conceptuales y pragmáticos al diseñador para que asuma la complejidad de la producción de información frente a la imposibilidad de abarcar la totalidad de lo que está afuera, para aplicar unos principios que le otorgan criterio de agenciamiento reflexivo, intencional y consciente que reconoce que los resultados de sus operaciones pueden presentar fricciones internas, comportar inadecuación entre lo concebido y lo que expresa la imagen del objeto, como también la autonomía del receptor para hacer su propia interpretación a partir de un gusto particular.

A continuación, se describe la síntesis de los capítulos de la presente tesis:

El Capítulo I Estado de la Cuestión, Problema, Metodología y Marco Teórico. Inicia dando cuenta de las perspectivas de investigación con relación a la práctica del diseño de las cualidades estéticas del objeto, las concepciones de la Estética en el diseño encontrando que la liderada por las ciencias formales se enfocan en identificar y formalizar el tipo de reglas que asisten la composición formal y su parametrización; las leyes perceptuales con relación a configuraciones de la apariencia de objetos ya surgidos de la práctica del diseño. El análisis de valores como 'función estética' que aborda la apariencia externa del objeto como medio de comunicación para el receptor en conexión con patrones previamente asimilados para identificar patrones de preferencia. Luego, la desarrollada por ciencias fácticas en el campo de las ciencias sociales y humanas que refieren a las condiciones y contextos en que el objeto ya constituido y no en su acto de creación desde la concepción estética. Con relación al caso Concept cars predominan las catalogaciones historiográficas no articuladas a la disciplina del Diseño.

En el marco teórico se traza una plataforma conceptual que abre la posibilidad de atribuir una serie de cualidades empíricas para hacer legible las condiciones de la experiencia de formación del conocimiento que el diseñador adquiere con la práctica para lograr su objeto de acción en correlación con su contexto de operación para configurarse mutuamente. En tanto fundamentos teóricos desplegados el propósito es hacer legible la estructura interna de funcionamiento de esa praxis en sus modos particulares de experiencia.

En el apartado de metodología se da cuenta del diseño de la investigación, su enfoque y el sistema de matrices de datos desplegadas para la construcción y análisis de datos.

El Capítulo 2 Pensamiento Estético analiza en la multidimensionalidad de factores, circunstancias, contextos y objetos la formación del pensamiento estético en la praxis General Motors de los Concept cars para caracterizar la estructura de formación del pensamiento estético como conjunto de concepciones que guía el actuar proyectual para estructurar la apariencia del Concept car como objeto estético. 
El Capítulo 3 Acto de Diseño de la Estética del Objeto se caracteriza el conjunto de operaciones relacionales y performativas (esquematismo y diseño conceptual) que el diseñador ejecuta para la construcción progresiva de una estructura de contenidos que determina la esencia o carácter y las cualidades formales de la estética del Concept car. Deconstruye las operaciones retóricas de metáfora, adjetivación, narrativas con las que el diseñador desarrolla el carácter estético de la estructura formal del automóvil.

El Capítulo 4 Objeto Estético constata que el Concept car como objeto estético es multidimensional en su concepción y composición, así que se realiza una descriptiva de análisis cruzado de lo recogido en los capítulos previos de Pensamiento y Acto. Hace legible que se trata del producto del pensar - actuar y la intencionalidad del diseño; la estructuración de una información diversa que se organiza como narrativa autorreferente con mensaje metafórico, valores de representación de identidad, mensaje de ficción y un conjunto de cualidades formales con sentido estético. Como salida de las operaciones relacionales y performativas, se trata de una estructura sinérgica de contenidos. Se trata de una manifestación material una imagen autorreferente, valores de representación de identidad y de belleza funcional para la conexión con el sujeto.

\section{CAPÍTULO 1: ESTADO DE LA CUESTIÓN, PROBLEMA, METODOLOGÍA Y MARCO TEÓRICO}

\section{Estado de la Cuestión, Problema, Metodología y Marco Teórico}

\subsection{Estado de la Cuestión}

Tomando como punto de partida la práctica del diseño con relación a la producción (ideación-determinación) de las cualidades estéticas del objeto y las concepciones de la Estética en el diseño se encuentran dos perspectivas de investigación.

1. La liderada por las ciencias formales en disciplinas como la Psicología perceptiva, la Ingeniería de producto, el Marketing que se interesan por identificar y formalizar el tipo de reglas que asisten la composición formal y su parametrización; las leyes perceptuales con relación a configuraciones de la apariencia de objetos ya surgidos de la práctica del diseño. También el análisis de valores como 'función estética' que aborda la apariencia externa del objeto como medio de comunicación para el receptor en conexión con patrones previamente asimilados para identificar patrones de preferencia.

2. La desarrollada por ciencias fácticas en el campo de las ciencias sociales y humanas que refieren a las condiciones y contextos en que el objeto ha sido diseñado en una cierta época. Principalmente presente en el segundo aspecto: Concept cars 
De esas perspectivas de investigación, se encuentra una mayor participación de las ciencias formales y con tres enfoques predominantes:

- Estética del diseño. En el que el concepto de la estética se integra como un conjunto de cualidades de la superficie exterior del objeto en tanto mensaje con significado.

- Experiencia Estética. Para identificar cualidades atractivas para el receptor y la comprensión de procesos de percepción con respuesta emocional. En sus abordajes se encuentran: la mirada objetivista que se centra en la composición formal de objetos sometidos a testeo y la subjetivista, que privilegia la indagación de patrones y memorias que constituyen la preferencia de los individuos.

- Propiedades estéticas del diseño del objeto. Con dos ejes: el primero se enfoca en el enlace de leyes compositivas con relación a modos perceptivos para la experiencia estética. El segundo a la identificación de valores simbólicos y otros de significado.

\subsubsection{Estética en el Diseño}

Folkmann (2013); Friberg (2013) aproximan la Estética como plataforma conceptual para la producción de significado en la forma del objeto en vínculo con procesos de percepción y consumo. La estética del objeto es tratada como un aspecto estratégico para analizar cómo el diseño opera en tanto acto de comunicación y distribución de significados, símbolos y valores de orden contextual. Se indagó en diferentes expresiones materiales y sus efectos inmateriales como experiencia estética para la comprensión de creación de significados. Se releva la escasa investigación de la estética con propósitos de delimitar un concepto de diseño estético con relación a la teoría y un sistema de referencia de su historia, en consecuencia, señalan que la práctica de los diseñadores se ve limitada a las propiedades del aspecto físico o lo que peyorativamente algunos asocian con 'estilistas de maquillaje' del producto.

Pokropek (2015) en su investigación en morfología arquitectónica y de objetos, aproxima la Estética como un mecanismo de producción de la forma a través de la combinación de narrativas y contenidos simbólicos con asociación a la memoria filogenética y ontogenéti$\mathrm{ca}$, los cuales se disponen intencionalmente para la experiencia estética y su consiguiente respuesta emocional. En su estudio, el mensaje de la forma del objeto debiera ser polisémico y autorreferente. Refiere a la forma como una estructura lógica de estructuras rítmicas y categorías que se visualizan en la sintaxis para ser interpretadas semánticamente con relación a las prácticas sociales que las producen y consumen.

Patrick y Hagtvedt (2011) estudiaron la Estética desde la doctrina filosófica y vinculan la noción de belleza para analizar las cualidades formales del objeto y articularlas a la respuesta del observador en el marco del consumo, catalogando las emociones y conductas que determinadas apariencias promueven en las personas. Se concluyó que la ornamentación y la carga simbólica justifican la apariencia del objeto, con la existencia de excepciones según el contexto y naturaleza de los productos.

Folkman (2013) desde una perspectiva más cultural, la estética del entorno es conceptuada como un fenómeno de estetización de la vida cotidiana, el cual consiste en la distribución de significados históricos y culturales y mensajes expresivos en la composición formal de 
mobiliario y luminarias de uso residencial. En su planteo de producción de material significante en conexión con el contexto, la Estética es una plataforma para la innovación en las cualidades de la apariencia del objeto y para la experiencia con el mismo. Un estímulo a la imaginación del receptor y del diseñador. En este trabajo la producción estética del objeto dista de la del objeto del arte en lo que concierne a la construcción de significados que están condicionados no sólo por la categoría funcional, los aspectos canónicos de belleza, los símbolos de valor cultural. También a otros referidos al entorno de experiencia cotidiana en el que las personas poseen sus propias necesidades, expectativas, modos de interpretación y de experiencia estética, definida ésta como percepción sensible del sujeto al valor intrínseco del objeto: su mensaje y las cualidades de su superficie material.

Drugh, Metz y Weyand (2011) analizaron las cualidades visuales de la apariencia como aspecto crítico para la diferenciación y éxito del producto en el mercado. Los aspectos comunicativos de naturaleza simbólica son identificados relacionados como aspectos de intercambio con valor de persuasión para el marketing con foco en patrones y aspectos del consumo.

Eisenman (2013) indagó las limitantes entre estética y tecnología en el marco de su factibilidad. Desde el enfoque de la estética de lo diseñado como factor de éxito en el mercado, este análisis del carácter simbólico de los atributos formales de los productos lo interpreta como un medio de comunicación para facilitar la interacción y conexión emocional con los consumidores. Tanto estética como tecnología cumplen su función en la transformación del producto para avanzar hacia la innovación. Sobre la tendencia de consumo, el autor identificó que las personas aprecian en el aspecto visual de la forma, significados compartidos por la dinámica social y el contexto al que pertenecen, como también se sienten atraídos por aspectos físicos novedosos, representados en valores de apariencias, funciones, materiales, significados e interacciones desconocidos.

A partir de ello, la comunicación de la forma se aborda en un nivel multidimensional en correspondencia con la aptitud de las personas para interpretar los significados contenidos en el aspecto físico y cruzarlos con sus propias expectativas. Este trabajo abre los interrogantes ¿Qué deben saber los diseñadores acerca del sentido estético del diseño? ¿Cómo los diseñadores lidian con la distancia entre su propuesta y las expectativas de las personas para conectar con ella?

Hustwit (2010) adelantó un análisis sobre la producción de significado y representación de valores de identidad como valor poético del diseño, en el que el componente cognitivo del observador reconoce (o no) esos valores, y un componente afectivo vincula memorias que inciden en la respuesta emocional del receptor. La composición de contenidos de valor simbólico va a estar asociada, además, a una composición figurativa en función de la interacción práctica. Este valor poético eleva la noción de mercancía atribuida a los objetos por la incidencia que este tiene en la conducta y emociones de las personas. En línea con Norman (2004) en su análisis de la producción de diseño con valor poético se asocia la configuración formal del objeto con un balance de tres componentes: 1. Emocional para la interpretación del mundo. 2. De entendimiento de la relación entre lo afectivo y lo conductual con respecto a la producción artificial. 3. Una composición figurativa que atiende a la función práctica. 
Döring (2010) estudió la relación de la estética del objeto como medio de experiencia. En su abordaje el sujeto otorga un valor emocional a las cualidades percibidas, las cuales son intrínsecas del objeto y acuñadas como 'cualidades emocionales'.

\subsubsection{Experiencia Estética}

Leder y otros (2004); Hekkert (2006); Jagtap y Jagtap (2015) desarrollaron estudios que se enfocan en la articulación de la apariencia externa del objeto y los procesos perceptivos, con sistematización de las etapas que van de lo sensorial, a lo cognitivo y a la reacción emocional para identificar cualidades de preferencia, encontraron como destacadas: la novedad, la de familiaridad y la de contraste.

Crilly, Moultrie y Clarkson (2004) con una implicación de conexión emocional del sujeto a cualidades de la apariencia como apariencia, unidad formal, líneas orgánicas y asociación con valores semánticos que evocan significación contextual, en su planteo el juicio de placer sensual (sentidos y sensibilidad) está condicionado por la interpretación del mensaje expresado por la forma. Su noción de objeto estético se trata de una composición de atractivo sensual; una codificación intencional de significado estético que llama la atención para que se establezca un diálogo entre el sujeto y la forma del objeto. Preguntándose ¿por qué nos gustan ciertos objetos? observaron tres categorías para aludir a la estética del objeto: la primera, orientada al análisis de principios de diseño formal, la segunda, a valores apreciables en la apariencia inteligible (semánticas, simbólicas, referenciales). Refieren la interacción estética - semántica al sentido de identidad que las personas otorgan al aspecto visual del objeto. El valor simbólico percibido por los sujetos relativo a la representación de factores sociales como estatus o distinción social en relación con el gusto ${ }^{1}$ por la estética del objeto.

Hekkert (2006) desde la Psicología evolutiva vincula la percepción sensorial con relación a la experiencia estética para estudiar el por qué se experimentan ciertas cosas como gratificantes a los sentidos. Esta investigación empírica se fundamentó teóricamente en el modelo de 'esquema estético' desarrollado por Leder y otros (2004). Descrito como ciclo iterativo, recorre en la apariencia del objeto, una percepción sensorial, luego cognitiva para el reconocimiento de significados de valor simbólico y patrones, posteriormente una respuesta emocional frente a cualidades específicas como son: novedad, detalle, unidad en la variedad, carácter y efecto máximo en una composición denominada limpia, es decir, una forma que puede ser visualmente recorrida sin mayor interrupción y con bajo esfuerzo cognitivo. En este trabajo, la experiencia estética es un episodio de emoción como respuesta al ciclo.

Con relación a la experiencia estética, ésta presenta tres categorías diferentes que actúan como un conjunto inseparable en la percepción humana:

1. Unidad de placer sensual (algunos principios del gusto son uniformes y no por ello las reacciones ante ellos).

2. La interpretación significativa (el sujeto acude a memoria, interpretación y asociaciones de experiencias significativas previas) 
3. La implicación emocional (supone la evaluación de un evento en términos positivos o no, para dar lugar a sentimientos de placer o displacer). Acá la experiencia con el producto difiere de la clásica noción de experiencia estética del objeto de arte, de contemplación desinteresada, (especialmente las visuales), argumentando que la finalidad del objeto y los significados atribuidos a ellos, (los dados por el diseño más como señales indicativas y los añadidos por interacciones prácticas del sujeto con el objeto), complejizan la percepción en el sentido que hay un interés cognitivo de comprensión para cumplir una meta con su utilidad y no un mero goce estético.

Hekkert (2007) en otro estudio, la noción de adaptación desarrollado desde la perspectiva biológica como condición de supervivencia en que el sistema visual es el principal recurso para la asimilación de patrones organizacionales de información, funciones y apariencias del entorno (Goldstein's 2002) ${ }^{2}$, esta investigación examina la influencia de patrones previamente asimilados y su incidencia en la respuesta emocional a apariencias preconfiguradas. Desde pares polares: satisfacción - satisfacción, agrado - desagrado, deseo - rechazo, haciendo lo propio con las propiedades de la apariencia: contraste - unidad, novedad - iconicidad los hallazgos del testeo como juicios de apreciación positiva se trasladan a como intencionalidad estética para los diseñadores. Con este modelo y la descripción de la experiencia estética como un ciclo iterativo se validó lo que gusta o no. La vacancia está en la indagar en la práctica de diseño cómo se producen esos contenidos con relación al contexto de formación y apreciación.

Otra visión es la de un intercambio de realidad objetiva, la representada por la morfología del objeto en su condición utilitaria y la respuesta subjetiva del individuo, quien añade y otorga un valor estético no sólo por las cualidades de apariencia si no por la adición de significados en su interacción cotidiana.

Jane Forsey (2013) se propone una formular una filosofía estética para el diseño, indaga cómo se relaciona el diseño con los modos de experiencia de las personas con los objetos de uso cotidiano. Plantea que 'bello es el producto de la forma de nuestros juicios estéticos' en el sentido que atribuye plena autonomía al sujeto para la apreciación de belleza.

Blijlevens y otros (2017) desde una investigación empírica rastrean la respuesta emocional de las personas frente a la dimensión semántica de los productos. Este trabajo procuró el desarrollo de bases conceptuales para el testeo del diseño en tanto producción de representaciones, ratificando el carácter emocional de la experiencia estética. Los autores convocan al diseño en la producción de medios de valoración de su producto creativo, con límites que exceden la geometría, el color o cualidades sensoriales del material.

Pero y ¿qué hay con lo feo?, los diseñadores requieren conocer los contravalores de belleza, implantados en el contexto en el que operan. Las investigaciones de las perspectivas descritas suelen segregar las configuraciones rechazadas sin que se ahonde en el por qué entran en esta apreciación. Los diseñadores debieran atender este grupo para comprender a qué valoraciones están vinculados con relación a su composición no sólo morfológica, también al mensaje simbólico que desde allí se expresa y en su posible desconexión. 


\subsubsection{Propiedades Estéticas del Diseño del Objeto}

Wu Tyan-Yu, Tsao Chueh-Yung y Sie Cian-Yu (2017) trabajaron las propiedades estéticas: unidad formal y organicidad de líneas aplicadas a diferentes tipologías de automóviles de segmento medio (nicho de mercado de clase media) para constatar las reacciones de las personas a estos patrones. Mediante el cruce de fundamentos de la Estética como armonía o unidad formal con principios de Psicología sobre valoraciones cognitivas subconscientes asociadas a las emociones, el estudio empírico consistió en someter configuraciones con armonía y otros de no armonía formal, otros patrones con contraste de formas rectilíneas vs curvilíneas encontrando que las personas reaccionan con mayor interés y positivamente frente a figuraciones armónicas y de línea orgánica, aclarando que su acercamiento a la emoción sólo constituye una manifestación exterior de agrado o desagrado sin que se hayan explicado las conexiones internas que el sujeto o lo que hay detrás de la forma para dar cuenta de esta conexión.

Mayer y Landwehr (2017) adelantaron un estudio de rostros humanos con relación a respuestas de preferencia con el propósito de obtener una lista de cualidades de figuración que pudieran deslizarse a la composición formal del objeto. Allí concluyeron que no sólo simetría, proporción y un conjunto armónico es ratificado, también una imagen que es promedio, fácilmente reconocible para el entorno produce una respuesta positiva. Los autores denominaron tipología prototípica para revelar la importancia de una estética local y rasgos de familiaridad como punto de apreciación estética. Refiriendo a la tipicidad del diseño juega un papel sustancial en la evaluación subjetiva de una apariencia objetual estrechamente vinculada a un gusto ya asimilado.

Scott (2016) destacó la importancia del Diseño como ventaja competitiva en su aportación del valor diferenciador, en el sentido de que la apariencia del producto es el punto de partida para ofrecer a los consumidores una experiencia única con el producto. Su trabajo abordó la forma como un conjunto de atributos que deben favorecer interacciones destacadas, así los directivos de las compañías entienden que los diseñadores no sólo se ocupan del ornamento de los productos sino de la resonancia entre persona y objeto. Afirmó que para el 2015 en el Design Management Institute el índice de valor del diseño con relación al crecimiento de compañías como Apple, Disney, Nike e IBM alcanzaron un valor de $215 \%$. Jagtap y Jagtap (2015) adelantaron una investigación que busca encontrar parámetros para el proceso de desarrollo estético del automóvil hallando tres fundamentos:

- Sintaxis de la forma: Estructura y contenido visual.

- Funcionalidad de la forma: Representación formal de la función.

- Formato de diseño: patrones y cánones característicos del diseñador y de la marca.

Como hallazgos clave:

1. Que los diseñadores, consciente e inconscientemente se enfocan en un patrón estilístico y descomponen en fragmentos el producto para atender de manera jerárquica su composición, por ej.: en un automóvil, el frontal, las puertas, las ruedas deben ser tratadas primero, de manera independiente y luego, como conjunto, creando además un concepto que satisfaga sus intenciones y las del consumidor. 
2. Procuran el desarrollo de un concepto que reúna el mensaje del diseñador y el de la marca, un sello característico del entorno de diseño del automóvil.

3. Los diseñadores acuden como inspiración para la concepción estética a pares polares: similar - diferente, histórico (precedente) para producir detalles nuevos y a referentes de la naturaleza con artefactos. Exaltaron el valor una evolución formal que se asimila a la genética; una mezcla continuada de unos rasgos que dan identidad a modelos, series y marcas pero que para la siguiente generación aportan nuevos rasgos de apariencia y desempeño. Y esto como una eficaz relación entre lineamientos de diseño y el talento, experiencia, educación formal y la imaginación que operan en el diseñador para producir bocetos a mano como expresión de sus ideas las cuales se irán refinando en un proceso interactivo e iterativo.

4. Se destacan las habilidades comunicativas respaldadas en un conocimiento sobre valores de marca, la construcción de un mensaje para los consumidores, factores externos de orden ideológico, y de la cultura material.

5. Un asunto central del diseño es: la relación forma - materia la cual parte de una conceptualización y la modelación en función de la sintaxis propia del automóvil e indican que el frente hace las veces del rostro del auto, el cuerpo o los detalles tienen diferentes niveles de representación asimilables a la identidad humana.

El material es tratado como un medio de estímulo visual, de mensaje tecnológico y de carácter de identidad. Los autores adhieren al postulado de Vilém Flusser (2002), que parte de la interpretación de diseño como acto intencionado dotado de pensamiento, de ideas que se unen a la técnica para producir mundos alternativos en donde las formas aparecen. Con su noción de que la apariencia del material es la forma, aluden también a la dualidad de ilusión - realidad en donde la forma como fenómeno construido, toma presencia con la materia que es su representación.

Las propiedades sensibles que se presentan permiten al sujeto experimentar un goce y realizar una especie de creación al revés, en lugar de sacar el objeto de la nada. El binomio forma - materia está estrechamente vinculado al proceso de diseño y su valor radica en la concepción de la primera. Sus hallazgos concluyen que el diseñador abstrae e interpreta elementos pasados para prospectar formas futuras que se traducen en esquemas visuales con baja producción discursiva de nivel semántico en el acto creativo para potenciar la representación en la forma.

Jagtap y Jagtap (2015) señalaron la vacancia de la investigación del diseño alrededor de: estética y creatividad, novedad y diferencia como creación estética, en consecuencia, la dificultad para dar cuenta argumentada de: ¿Qué es un producto estético?, ¿Cómo opera el proceso de diseño estético para los diseñadores?, ¿Cuáles son las estrategias en términos de la definición de estilos para asegurar la aceptación del consumidor?

Abidin, Warrell, y Liem (2011) investigaron la significancia de las características visuales de la forma y su contenido representacional con relación a la intencionalidad de conectar con las personas y de producir innovación en la composición formal. En su abordaje de perspectiva constructivista, reconocen la relación de cultura y diseño para comprender los lenguajes y mensajes de contenidos simbólicos y patrones que son incorporados a la forma en combinación con rasgos de innovación. 
Para constatar el acierto de la propuesta formal y de los elementos que son valorados como cualidades estéticas, observan cada etapa del proceso perceptual y las diferentes respuestas asociadas:

1. Sensación: reacción a estímulos externos con foco en la percepción visual como punto de entrada, para identificar el orden de interés y encuentran que lo nuevo o desconocido prima sobre el reconocimiento de rasgos previamente asimilados.

2. Organización perceptual: vinculada a la fácil asociación, implica memoria de imágenes.

3. Identificación y reconocimiento: como acto racional involucra significados y conceptos.

En línea con el planteo de Dewey, los autores mencionan que debe incrementarse el mensaje simbólico y detalles de novedad y contraste a la composición para obtener interés y una activación de mecanismos sensibles y no sólo cognitivos.

La experiencia estética con el producto es subjetiva, con enlace a contenidos socio culturales; el desafío del diseñador es incorporar parte de ellos al mensaje formal. Destacan como cualidades: lo familiar, la iconicidad, la repetición de patrones con variaciones que no distorsionen la comprensión de la categoría funcional.

Los autores concluyeron que uno de los atributos clave que distingue a los productos innovadores, está ligado a su mensaje estético el cual es interpretado como una conjunción de significantes y cualidades que pasan de lo sensorial, a lo cognitivo y a lo afectivo como valor significativo con el cual se identifican las personas.

El segundo aspecto corresponde a los Concept cars como objeto de estudio de la producción y el producto del diseño con valor e intencionalidad estéticos en un episodio histórico.

\subsubsection{Concept Cars de General Motors en Estados Unidos}

Los investigadores de este grupo de automóviles de la General Motors coincidieron en que pese el carácter experimental y disruptivo de los Concept cars, constituyen una producción y producto autónomos (que poseen sus leyes internas) y autorreferente en tanto representa un nuevo paradigma (pensar, actuar del diseño y estética del automóvil).

De los antecedentes encontrados, se destaca el estudio de Gartman (1994), que con su mirada sociológico - histórica se ocupó principalmente de la recopilación y organización de hechos significativos con relación al evento de diseño estético de los automóviles entre 1930 's y 1960's. Preguntándose cómo las tensiones económico - políticas y sociales involucran a los diseñadores a cargo de las propiedades estéticas de la apariencia del automóvil, y quienes, debieron agenciar la información externa e interna para el diseño formal con intencionalidad de conexión emocional con las personas. Su trabajo aporta insumos de análisis de contexto para comprender factores externos que atraviesan la concepción del valor y la función estéticos de la forma.

Otros trabajos de línea más descriptiva y de catalogación, ofrecen características de las propiedades conceptuales, contextuales y de figuración relativa al diseño formal de los Concept cars y la estética como un factor de impulso de la innovación con enlace a la tecnología, mientras que el diseño es visto, como gestión estratégica de los intereses institucionales y como acto de comunicación. 
Los autores coinciden en que el diseño estético de los Concept cars puede interpretarse como un acto de comunicación, una ideología respecto a su visión futurista, su fuerza simbólica, y formas disruptivas con respecto a los arquetipos vigentes en la época. En tanto práctica socio cultural el desarrollo del concepto fue nutrido por la reacción y de las personas al exponer el automóvil en una escena intencional para la retroalimentación. Por otra parte, el proceso creativo que incluyó producción semántica de metáforas, adjetivación y narrativas fue conectado externa e internamente por los diseñadores que a través de la mediación de prototipos establecen un intercambio de significados, características en el aspecto físico y en las narrativas de su puesta en escena como fue el caso del auto espectáculo Motorama.

Gartman (1994), desde una perspectiva histórico - sociológica investigó la estética del automóvil partiendo de reconocer que el éste es uno de los objetos con mayor penetración en la vida social y cultural de las personas en el entorno estadounidense (en el sentido de que es el objeto con mayor contacto en la vida cotidiana, un modo de hábitat en el que se crean memorias y adhieren significados, así como un medio de proyección del estatus social). También identificó al automóvil como el producto más privilegiado de la sociedad de consumo en su esfuerzo por su desarrollo y apreciación estéticos.

Su análisis se centró en la relación entre el desarrollo de las cualidades estéticas de los autos y las tensiones presentes en la sociedad norteamericana en el marco del incremento de la producción en masa y la conformación de valores de identidad social estadounidense. Aunque su lectura del objeto se hace desde afuera y la describen como manifestación de una apariencia atractiva, reconoció la estética del diseño como un medio de construcción de significados expresados y transformación de la vida cotidiana, la identidad institucional, social y personal, la expresión de un sentir estilístico que movilizó física y psíquicamente a las personas.

Concluyó que el diseño estadounidense copió, interpretó y recreó la estética en función de su ideología y realidad local. La idea de estética no se fundamentó en pretensiones de competir con los alemanes o con la tradición artística italiana o con el manejo estético de elitismo francés o la sofisticación inglesa. Su rival fue la Ford y su paradigma ortogonal, austero subordinado por la búsqueda de bajo costo y funcionalidad. Su pensamiento estético del streamlining ${ }^{3}$ es aerodinámico en el sentido metafórico de expansión del progreso, democratización de la economía, y un mensaje de dinámica, libertad y velocidad de crecimiento social, además de observar la conexión con formas orgánicas que ya había recorrido Raymond Loewy en los 1930's. Acuña la expresión aero aesthetics para referir a una formación de estructuras relacionales de cualidades estéticas vinculadas a la tradición del gusto y la noción de belleza, pero con un marco hegemónico denominado institución mercado que le impuso tensiones subjetivas - objetivas a los diseñadores y una perspectiva diferente de la composición estética en tanto construcción de sentido para los intereses corporativos de conexión con las personas con propósitos comerciales.

Describió los factores externos que atravesaron la composición de las propiedades estéticas en el contexto de génesis y apreciación del automóvil, y destacó, la agencia de los diseñadores para crear sinergia entre el mensaje y el aspecto físico del cuerpo del automóvil. También indicó que la presión de los diseñadores fue la articulación con lo institucional y la reacción de las personas. 
Rees (2000), realizó una catalogación de los Concept cars en sus diferentes expresiones en el mundo atribuyendo a la General Motors de Estados Unidos el origen de este legado del diseño con el Buick Y - Job en 1939. Resaltó además que los años 50’s fueron los años dorados de la era del automóvil y Estados Unidos fue el centro de la exploración del diseño y la innovación en la apariencia, formatos, expresión simbólica y conexión con la vida social y cultural con las personas, además del mensaje de nación frente a sus desafíos tecnológicos, económicos y políticos hechos explícitos en los diferentes modelos y en su promoción. Contrastó la perspectiva estadounidense con la europea que conservó la línea de expresión artística, elitismo y sofisticación en las líneas de los cuerpos de los automóviles con la democratización del consumo en Estados Unidos y una valoración estética más orientada a su valor simbólico; a la anticipación del futuro con lo que se pudo concretar en el presente. La expresión de abundancia y progreso atribuyendo personalidad y escala a los autos para poner el sello americano.

Autos más grandes, más largos y pesados. Con intención de alta resonancia emocional y vinculación a la puesta en escena con expresiones de la moda, artes escénicas, las relaciones sociales y la construcción de nación después de la segunda Guerra Mundial. El autor relató la asociación del momento tecnológico: era aeroespacial, aprendizaje tecnológico de producción de armas de guerra, otorgó insumos para la exploración de superficies, materiales, brillos y alto contraste en los detalles.

Describió que el pensamiento estético se caracterizó por la extravagancia, la visión futurista y la fuerza en el mensaje que los autos presentaban. Su apariencia contenía rasgos de representación, referencia y conceptos de novedad, iconicidad y diferencia. Precisando que su primer objetivo, no fue el convertirles en modelos comerciales, sino, un medio de interacción y retroalimentación a partir de las respuestas de las personas alrededor de la fantasía y la escenificación como posibilidades de innovación. Para Rees, los Concept cars fueron un ejercicio de exploración imaginativa, de construcción de un estilo tanto de línea estética sino de innovación con sello estadounidense, que trascendió a la vida social y a otras fronteras.

La conceptualización del carácter de la apariencia combinó las posibilidades tecnológicas de: funcionalidad y materialización en el aspecto físico. De esa manera, los Concept cars enlazan la exploración estética a la innovación tecnológica y a la movilización simbólica de imaginarios sociales.

El autor describe el legado de diseño de los Concept cars también conocidos como Dream cars, como un acto de comunicación y la expresión explícita de una conceptualización disruptiva que adquirió una identidad en tanto práctica y como producto.

Y describió el carácter estético de la forma de los Concept cars, con líneas curvadas, orgánicas como el inicio de un patrón de preferencia sobre formas rectilíneas con valor simbólico, que prevalece hasta la actualidad.

Temple (2015) realizó una investigación que describió como exploración arqueológica sobre el fenómeno de diseño de los Concept cars y el auto espectáculo itinerante denominado Motorama de la General Motors entre 1941 y 1961. Su propósito principal fue relevar el valor de significancia cultural para la historia del automóvil estadounidense que tuvo la apuesta institucional que la General Motors hizo al integrar el diseño como medio estratégico entre el pensamiento institucional y las personas para ubicar al auto como punto de articulación de pensamiento futurista, de innovación y de su interpretación estética. 
Expuso que Motorama y los Concept cars representan más que un medio de impulso de negocios, una institución cultural, de creación de comunidad, que ha trascendido en la historia dando lugar al tratamiento de estos automóviles como piezas de colección que continúan siendo exhibidas en los más importantes museos de arte del mundo y rodando en exhibiciones en las que es evidente la emoción de las personas que le otorgan sentido. Para Temple, el styling evolucionó de un estilo a un proceso de determinación del carácter de las propiedades formales de los automóviles, que va más allá de la figuración de la forma como aspecto físico. Se trata de la forma como conjunto total o form en inglés; una construcción de estructuras conceptuales que combinan valores de identidad, la capacidad de conceptualización de la forma como anticipación del futuro expresada en la imagen física del automóvil.

Los Concept cars y Motorama reúnen un acto de comunicación y expresión que procuró promover y percibir la emoción a través del automóvil como medio de articulación y por la estimulación de fantasía que comportó su puesta en escena. Su indagación por el desarrollo del diseño se enfocó en el objeto como obra singular y concluyó que ésta se caracterizó por: una propuesta de innovación disruptiva y el trabajo interdisciplinar.

Con respecto a forma - función el autor destacó el liderazgo distintivo de Earl y su equipo de diseño para determinar el carácter y las propiedades del aspecto físico en trabajo colaborativo con los ingenieros, pero no el conocimiento proyectual allí producido.

Estética - materialización refiere al rol de innovación que promovió la línea orgánica y el uso de contraste apoyado en las propiedades sensoriales (en el sentido de estímulo visual y táctil) de los materiales para la manufactura.

El intercambio de información sujeto - objeto destacó la agencia del diseñador Earl en la gestión de la información externa e interna para estructurar los conceptos y la figuración. Relevó la producción narrativa, el uso de la metáfora y la fuerza simbólica de su expresión. La exploración de la expresión a través de los prototipos como medios de retroalimentación y refinamiento para la concreción. Aunque el objetivo primario de los Concept cars no fue su evolución a modelos comerciales, su valor radicó en la percepción de innovación estética disruptiva como factor estratégico de competitividad.

El autor describió el pensamiento estético styling liderado por Earl como una posición ideológica que procuró fusionar arte y máquina con visión futurista. En los Concept cars la estética constituye una plataforma de conceptualización en contexto con fuerte producción metafórica, adjetivación del carácter (personalidad) proyectado en cada modelo y la representación de valores de identidad para la conexión de la institución (marca) con la sociedad objetivo (mercado).

Y concluye, mencionando que, la General Motors lideró el proyecto de diseño conceptual, el cual prevalece en la actualidad y constituye una de las operaciones del acto creativo más determinantes del carácter de la apariencia, la innovación y su enlace a la experiencia placentera como asunto nuclear del proyecto. 


\subsection{Problema de Investigación}

La expresión: 'diseño de la estética del objeto' tiene varias acepciones: 1 . Como práctica de diseño para determinar las cualidades formal-estéticas del objeto. 2. Como producto surgido del proceso: conjunto de cualidades estéticas de la forma del objeto. 3. Como campo de comprensión filosófica de la estética con foco en la comprensión de la noción belleza en relación con aspectos emocionalmente atractivos en la apariencia del objeto.

En la práctica del diseño del objeto la estética suele ubicarse como "función estética intencional" (Genette, 1999, p. 2) dirigida a procurar unas cualidades en el objeto para ser percibidas y experimentadas estéticamente. Esto supone para el diseñador reconocer que unas composiciones promueven más que otras una experiencia placentera que no depende solamente de atender a leyes compositivas de figuración; deberá procurar una formación y articulación de significados que provienen de su audiencia receptora. ¿cómo se produce esa apariencia atractiva para la función estética? Muchas prácticas se limitan a la observación de referentes para sus mutaciones, variaciones. Si bien, la imitación es una acción legítima, el diseñador construye el mensaje en conexión con valores de contexto que no siempre coinciden con los patrones de los referentes.

Por lo tanto, la estética del objeto comporta dimensiones de atractivo sensorial, cognitivo y contextual y muchos diseñadores no han desarrollado la habilidad de interpretación de otro tipo de información que circula en las representaciones e imaginarios de la sociedad y que pueda ser codificada estéticamente en la estructura formal.

Por otra parte, se reconoce una insuficiencia de investigaciones específicas con posibles combinaciones de material empírico y fenómenos (procesos, objetos, contextos, personas) y el papel del contexto sociohistórico como condicionante del pensar-actuar de los diseñadores; por lo tanto se desconoce 'desde dónde,' 'con quién' 'para quien se diseña' 'qué condiciona y conforma el carácter estético de lo diseñado' 'qué referencia el objeto diseñado' para dar cuenta de cómo al interior de la experiencia se constituye una estructura particular que guía las diferentes acciones del diseñador.

Desde las perspectivas de enfoque conocidas como investigación para el diseño: desde lo valorativo o desde lo fáctico, su exploración no suele articularse a la indagación de cómo están producidas las concepciones estéticas de los diseñadores, dada su baja participación en la investigación científica y en la capitalización de hallazgos de las disciplinas exógenas a la disciplina. Esto hace que esta instancia clave del conocimiento proyectual y que ha dado lugar a las propiedades de objetos constituidos, permanezca oculto. Por lo tanto, las ideas, estructuras, conceptos, operaciones resultan difíciles de describir por su no visibilidad para el contexto de comprensión.

Se reconoce que la baja participación de investigación sobre el diseño que toma por objeto de estudio la práctica de diseño indagando por la formación del pensamiento estético del diseñador; las circunstancias, factores, tradiciones de contexto desde las que conceptualiza, idea y figura las propiedades formales para su atractivo emocional. En ese sentido, el diseño de la estética del objeto se aproxima como un modo de producción de la imaginación sin que se hagan explícitas la información de sus abstracciones y cómo esta es recreada en nuevas propuestas. 
En ese mismo ámbito de investigación se desconoce, además, la consistencia entre las intenciones conscientes del diseñador (lo deseable del objeto) respecto de las cualidades obtenidas, tampoco el grado de correspondencia entre la concepción del carácter estético (anticipación de cualidades que otorgan un mensaje en función del contexto para la figuración de la superficie material del objeto) y lo que el objeto surgido en su apariencia, comunica versus lo que se percibe de esa apariencia.

Entonces, la práctica del diseño reclama integrar conocimiento de su producción - producto y de otros saberes para reflexionar en el cómo se concibe, configura y concreta el sentido estético de la estructura formal y no sólo en la especificidad de las cualidades visualmente perceptibles. Se requiere la indagación acerca de los fundamentos que asisten la intencionalidad estética y el grado de adecuación que alcanza el acto de diseño, como también el cuestionamiento acerca de la habilidad proyectual para detectar las desviaciones o pérdidas de la unidad formal concebida y de la percibida.

A partir de lo expuesto anteriormente, identificamos como problema de investigación la necesidad de hacer legible en la praxis ${ }^{4}$ del diseño, factores, circunstancias que forman el pensar y el hacer para reflexionar su producto estético y la agencia de los diseñadores con relación a su campo de operación, el cual reconocemos, como un complejo de factores modeladores, condicionantes, de contribución dinámicos para la práctica de diseño.

Esto precisa identificar un caso de estudio para la caracterización factores, de los elementos componentes en sus atributos esenciales y las relaciones que guardan entre sí.

Para operacionalizar el problema se opta estudiar la praxis de los diseñadores de los Concept cars de la General Motors en Estados Unidos entre 1945 y 1965 el cual será examinado en su estructura interna de funcionamiento, tomando tres instancias de análisis: 1. Pensamiento estético. 2. Acto de diseño conceptual de la estética del objeto. 3. Objeto estético: cuerpo exterior del automóvil.

Como recorte de estudio, esta investigación excluye factores tecno - materiales o indagaciones vinculadas al desempeño técnico funcional o de las funciones prácticas como condicionantes de la forma. También se excluyen comparativas con otros contextos geográficos dada la naturaleza particular, compleja y multidimensional de esta experiencia y el reconocimiento de Estados Unidos en el recorte temporal como el centro punto de origen de esta exploración hacia nuevas dimensiones estéticas en correlación con el contexto y las instituciones inmediatas para la praxis de los diseñadores.

\subsubsection{Preguntas, Hipótesis y objetivos}

A partir de la definición del problema se derivan las siguientes preguntas de investigación: ¿Cómo puede describirse la praxis del diseño de la estética de los Concept cars con relación al contexto de operación de los diseñadores General Motors en Estados Unidos entre 1945 y 1965 ?

Hipótesis Central: La praxis del diseño de la estética de los Concept cars de los diseñadores General Motors en Estados Unidos entre 1945 y 1965 puede describirse como un pensar y hacer intencionales y condicionados por las circunstancias socio históricas y determinaciones institucionales que el diseñador agencia en su multidimensionalidad desde operaciones relacionales y performativas para concebir un carácter estético que es referente 
y autorreferente expresado como mensaje metafórico y de ficción en la apariencia del cuerpo del automóvil Concept car.

Objetivo principal: Hacer legible el conocimiento de la praxis del diseño de la estética de los Concept cars mediante la caracterización conceptual de las operaciones - productos con relación al contexto de operación de los diseñadores de los Concept cars de la General Motors entre 1945 y 1965.

De la pregunta principal, su hipótesis y objetivo se derivan otros de tipo auxiliar:

Pregunta auxiliar 1: ¿Qué caracteriza la concepción de la estética del objeto en la praxis de los diseñadores de los Concept cars?

Hipótesis auxiliar 1: La concepción de la estética del objeto en la praxis de los diseñadores de los Concept cars se caracteriza por su naturaleza relacional y performativa para la intencionalidad del diseño GM para la construcción de un mensaje de ficción y valor identitario a ser manifestado en la imagen del automóvil.

Objetivo auxiliar 1: Caracterizar conceptualmente el pensamiento estético de los diseñadores con relación a las circunstancias de su formación considerando la ideología, objetos, personas e ideas institucionales del contexto sociohistórico.

Pregunta auxiliar 2: ¿Qué caracteriza el acto de diseño de la estética de los Concept cars? Hipótesis auxiliar 2: El acto de diseño se caracteriza por un conjunto de operaciones condicionadas, relacionales y performativas para estructurar narrativamente el carácter estético de la estructura formal del automóvil.

Objetivo auxiliar 2: Develar el carácter de las operaciones - productos con relación a su intencionalidad estética para el diseño formal del objeto.

Pregunta auxiliar 3: ¿Qué distingue al Concept car como objeto estético con relación a lo que expresa su imagen externa?

Hipótesis auxiliar 3: Lo que distingue al Concept car como objeto estético son sus cualidades de expresión autorreferente y referente en una apariencia que exhibe profusión en sus detalles, mensaje metafórico y de ficción en correspondencia con su concepción estética. Objetivo 3: Develar el carácter estético de la estructura formal y constatar la sinergia de sus contenidos con relación a lo que expresa la imagen del cuerpo del automóvil en la serie de los Concept cars.

\subsection{Metodología}

\subsubsection{Enfoque}

Inscrita en la línea temática de Forma y Materialidad, esta tesis de enfoque cualitativo combina diferentes perspectivas de indagación en el estudio de caso único Concept cars de la General Motors en Estados Unidos entre 1945 y 1965. Con centro en el fenómeno del diseño de la estética del cuerpo del automóvil procura hacer explícito un conocimiento adquirido en su experiencia proyectual desde la deconstrucción interpretativa de sus contenidos verbales, gráficos y materiales para la confrontación relacional y crítica con instrumentos teóricos. 
Optamos por el enfoque cualitativo porque sus diferentes atributos de investigación permitieron abordar la naturaleza particular del fenómeno y que describimos a continuación:

1. Esta investigación exploratoria examinó desde diferentes ángulos la producción y el producto del diseño de la estética del objeto que ha sido poco abordado; con variables desconocidas, con ausencia de un marco teórico integrado para su estudio, con antecedentes de investigación que se han centrado en la relación estética - diseño como medición de respuestas perceptivas frente a propiedades de la apariencia y no de cómo se produce el diseño de la estética del objeto. Fue preciso explorar la naturaleza de ciertas circunstancias, personas, contextos, objetos, relaciones, procesos en el contexto socio histórico del fenómeno para develar sus significados y vínculos con la formación del pensamiento estético; su razón de ser, concepciones, carácter e intenciones que guiaron el actuar de los diseñadores para componer y concretar la estética del Concept car.

Dentro del método exploratorio, la colección de datos implicó una visita de la investigadora al Heritage Center de la General Motors en la ciudad de Detroit Michigan, junio 14 al 24 de 2019 (ver apéndice 1 de postulación de la investigación y solicitud de acceso a la colección privada) en donde la selección del material empírico tuvo como criterios:

- Serie Concept cars General Motors por su valor distintivo de diseño de la estética como factor estratégico de marca.

- Recorte socio histórico como período de significancia para la profesionalización del Diseño Industrial, la institucionalización del diseño conceptual para la anticipación del carácter y cualidades estéticas de la forma. Un momento sociohistórico de aceleración de transformaciones en la ideología, los valores de nación para la adhesión de los individuos, abiertos a nuevos horizontes de tecnología, de estética y estilos de vida.

- Influencia del contexto desde el enfoque pragmático: situación de contenidos, circunstancias, ideologías y paradigmas particulares para el intercambio con el diseñador y la comprensión de formación de su pensamiento y actuar proyectual.

- Existencia de material original en representaciones verbales, gráficas, materiales como expresión explícita o tácita de la construcción de sentido estético para la concepción formal de los Concept cars.

- Contenidos de significancia para desocultar ideas, significados, concepciones y configuraciones que permiten ser contrastados y correlacionados con la teoría para su conceptualización y no sólo su descripción: narrativas escritas, visuales, en material videográfico; registro fotográfico y escaneo de recortes de periódico, magazines, piezas publicitarias, comunicados internos y externos, análisis y conversaciones con expertos.

- Como práctica se trata de una experiencia de los diseñadores en correlación con instituciones inmediatas y con un contexto espacio temporal localizado.

- Su manifestación material en la serie de modelos entre 1945 y 1965 ofrece heterogeneidad y continuidades en las imágenes susceptibles de ser comprendidas para interrogar sus cualidades como objeto estético del diseño y contrastarles con los instrumentos conceptuales para identificar consistencia, correspondencia, fricciones o resultados no esperados en la práctica. 
- Se trata de un contexto espacio temporal en el que el diseñador industrial se enfrenta a un aumento de complejidad de variables derivadas de las lógicas de producción en masa, la estética como factor de desempeño en el mercado de consumo, la necesidad de trascender la percepción de 'estilista de la forma' en el sentido de 'maquillaje' y no de profesional capaz de identificar un problema y estructurar su agencia para resolverlo trascendiendo un estilo y los existentes, valores hegemónicos y condicionantes racionalistas.

2. Como investigación descriptiva que se centra en situaciones que ocurrieron en el mundo real, facilitó describir cómo las personas vieron y experimentaron el sentido estético al explorar variedad de diversos significados, contextos y objetos en el material empírico.

3. Este estudio de caso único ofrece una complejidad en tanto representa un episodio histórico multidimensional para la producción del Diseño Industrial que implicó un recorte de la realidad para la deconstrucción de eventos, condiciones, factores que den cuenta de la situación histórica y las circunstancias de formación de sus ideologías, simbolismos en sus imaginarios. Fue necesario combinar diferentes perspectivas de estudio con multiplicidad de saberes desde teorías como la Estética, la Sociología de la cultura, la Psicología perceptual, la Semántica de Producto, Lingüística y Diseño. Y con ello hubo que desarrollar nuevos conceptos o perspectivas teóricas desde la deconstrucción de los datos y su descripción explicativa desde instrumentos teóricos.

4. En tanto tesis interpretativa que acude a un análisis comparativo busca las relaciones clave del fenómeno: al identificar el origen pragmático de la praxis de estudio focalizamos la correlación del diseñador con el contexto: sus intercambios y condicionantes.

5. Por otro lado, es explicativa en tanto intentó develar causalidades y relaciones estructurales para la concepción estética: diseñador y su campo intelectual, alteridad y experiencia estética, imaginarios, simbolismos, arquetipos y estereotipos como entradas al esquematismo de realidad que ejecuta el diseñador para comprender ideas, patrones y valoraciones precedentes.

6. A partir de una síntesis, con análisis crítico y correlacional se procedió a explicar el fenómeno desde instrumentos conceptuales que dieran cuenta del conocimiento que logró hacerse legible. Como tesis explicativa se comprometió con explicar el sentido estético del diseño formal del objeto, los valores de relación que suponen una construcción que hace un recorte de la realidad en reconocimiento de valores de alteridad, de la conjunción de sensibilidad y entendimiento para producir una fusión referente y autorreferente que suma objetividad y subjetividad. Un trabajo explicativo que, sin pretensiones de validez universal en las unidades significativas que expone desde saberes de la teoría, apunta a la plausibilidad del desocultamiento del conocimiento mediante una narrativa histórica que da cuenta sistemática de una construcción progresiva del pensamiento y actuar proyectual con representaciones como expresión explícita de su manifestación. 
7. Como tesis interpretativa de contenidos verbales y visuales abordó representaciones lingüísticas y no lingüísticas procurando inferir su significación simbólica, su correspondencia a construcciones mentales: ideológicas, fundacionales que pudieran cruzarse con instrumentos conceptuales y del bagaje del diseñador para obtener una comprensión holística bajo el rigor de la investigación.

\subsubsection{Estudio de Caso Único con Enfoque Histórico}

Desde el enfoque histórico: se trató de un análisis inmerso en un contexto sociohistórico en el que se acudió a una mirada sincrónica para observar cómo el fenómeno tiene una correspondencia temporal a él, posee rasgos de construcción única y de correspondencia a sus circunstancias. También con una mirada diacrónica se buscó la relación de las circunstancias del contexto para la evolución del hecho en un período de transición tanto para la sociedad estadounidense como de cambios estructurales para el diseño Industrial, su concepción estética y su aplicación en el primer sector industrial, de inserción social y cultural en los marcos de producción en masa y consumo de la Segunda Posguerra Mundial. Su relevancia radica en que al comprender de manera holística y detallada las causalidades con sus vínculos y los cómo de esta praxis se posibilita constatar su carácter de autorreferencia (construcción única que da cuenta de sus propias leyes de estructuración) y de referencia (en la conexión con la sociedad y la cultura de su génesis y aplicación) como un 'aprender del pasado para ir hacia el futuro'.

Desde el marco de enfoque cualitativo el caso único es apto para un estudio desde múltiples saberes, ángulos para su comprensión holística y para el análisis cruzado de teoría y práctica. Como caso histórico, el tratamiento de los contenidos implicó una exploración del fenómeno en las personas y sus ideas, objetos diseñados, los rasgos característicos del contexto sociohistórico y su relación con la formación del pensamiento estético, el acto de diseño y los objetos concretados buscando su intención, esencia y cualidades estéticas en conexión con la indagación de un problema que atañe al diseño contemporáneo.

Desde el método histórico se trató de una deconstrucción narrativa que describe eventos, instituciones, concepciones, arquetipos, estereotipos, fundamentos e intenciones con lo que los diseñadores ubicaron en qué punto estaban y hacia dónde se dirigían; ello implicó una caracterización de la ideología y factores promotores de su concepción estética. En tanto narrativa histórica supuso exponer las unidades significativas del fenómeno desde su descripción, conceptualización y explicación de su esencia particular como también de las relaciones de interdependencia para la construcción de un sentido de los eventos, decisiones, pensamiento proyectual y de las manifestaciones de sus concreciones; esto soportado en análisis de contenidos visuales, verbales, físicos en escritos, imágenes, material físico, prototipos.

Como complemento a ello se procedió a estudiar otros trabajos de análisis histórico, los cuales aportaron datos posibles de ser interpretados como evidencia histórica ${ }^{5}$ para contrastar con la deconstrucción e inferencia de factores particulares, generalidades que facilitaran la comprensión y constatación de los hallazgos y de las hipótesis.

Inscrito en un enfoque postfenomenológico, (combinación de fenomenología y pragmatismo), se observaron las condiciones de la experiencia de los diseñadores en correlación 
con el contexto para develar cómo se configuran mutuamente y derivar de allí las operaciones que otorgan la esencia estética del objeto. Luego sus representaciones verbales, gráficas, escritas y materiales se analizaron como correlatos o construcciones procurando inferir su significancia a la luz de la teoría con el desarrollo de un marco integrado de términos clave desde la Estética, la Sociología antropológica, la Psicología perceptual, Semántica del producto (con foco en expresiones de la retórica) y del Diseño Industrial. Sí bien un estudio de caso en un episodio histórico aporta datos que son considerados en la investigación, típicamente inexactos por la no pretensión de otorgarles un valor de validez universal, de lo que se trata es de conceptualizar los fundamentos que pueden ser extrapolables al pensamiento y actuar proyectual de los diseñadores de la estética del objeto en la actualidad.

\subsubsection{Métodos}

\subsubsection{Análisis de Contenidos: Verbal y Visual}

Se analizaron los contenidos de narrativas y los contenidos visuales para estudiar las representaciones mentales, gráficas y de objetos materiales del fenómeno de la praxis como también de las expresiones del contexto socio cultural en el que se produjo su experiencia de diseño. A través de su descripción y comparativa con las estructuras sociales y de sentido estético se posibilitaron inferencias con relación a estereotipos, arquetipos, estilo, preferencias de gusto como también rasgos que dan cuenta de la ideología y práctica estética como referencia social.

El análisis de contenidos aplicó pensamientos: divergente y convergente ${ }^{6}$ para interpretar el significado del lenguaje expresado tomando las palabras clave designadas como subunidades de análisis en sí (concentradas en la matriz de datos), según su conveniencia a la luz de nociones del marco teórico, que mediante su repetición, ocurrencia y pertinencia al aspecto analizado aportan al contraste con otras evidencias históricas y los instrumentos teóricos que soportan la argumentación. Se remarca que el investigador intentó ir más allá de la lingüística capturando la construcción de sentido como convergencia de los rasgos que caracterizan la situación, las relaciones de codependencia, adecuación y coherencia entre la intención y entre pensar - actuar del diseñador para finalmente confrontar con el objeto estético concretado.

Acorde con Woodward (2007) el análisis visual es de corte interpretativo, de naturaleza hermenéutica, que aborda imágenes y objetos como representaciones visuales a ser confrontados con los aspectos de indagación y los fundamentos conceptuales. A través de él pueden inferirse estructuras y relaciones sociales, patrones de gusto, expresiones sensibles de las personas en sus interacciones con otras y con su entorno. Aplicado a la forma del cuerpo del Concept car incluyó la observación de configuraciones formales como patrones de estilo, imágenes como representaciones de personas, contextos por sus rasgos distintivos de identidad y o carácter, también en el objeto o cosa material utilitaria visualizable en dos y tres dimensiones y que en su expresión permite explorar, describir, comparar y explicar, relaciones de su composición, contexto de génesis y apreciación, ade- 
más de detalles particulares. Para la población de la muestra, se trataron las imágenes de perspectivas, de lateral, frente, trasero y otros detalles.

\subsubsection{Fuentes y Colección de Datos}

Para este estudio de caso se accedió a fuente primarias, como los documentos originales del Heritage Center General Motors, en los archivos de su colección privada de diseño: comunicaciones internas, periódicos, comunicaciones institucionales privadas y públicas, artículos, declaraciones de entrevistas, narrativas, fotografías, documentales, muestras físicas (los prototipos de los Concept cars), piezas publicitarias como carteles y catálogos de modelos, objetos e imágenes. Como fuentes secundarias, hacen parte de esta investigación libros, otras investigaciones, artículos de autores reconocidos en el campo de interés. La originalidad de los datos creados en el tiempo de formación del fenómeno es confirmada por el Heritage Center de la General Motors como proveedor principal y autores reconocidos, como también publicaciones indexadas.

Samaja (2004) menciona que el acto de describir de manera científica una realidad como objeto de estudio es "un acto de redescripción y por lo mismo es ya una forma de modificar nuestro conocimiento previo" (p.149.). En términos de una descripción en el marco de la investigación científica, se precisa de procurar un marco integrado de conceptos explicitando el modelo teórico para que las descripciones se correspondan con el modelo. Esto supone poner al Diseño en diálogo con diferentes saberes de la Estética ${ }^{7}$ la Sociología de la cultura $^{8}$, Semántica del producto $^{9}$, la Psicología perceptual ${ }^{10}$, la Historia de Estados Unidos en la Segunda Posguerra Mundial ${ }^{11}$ y la Lingüística ${ }^{12}$.

Entonces, se realizó una búsqueda bibliográfica multidisciplinar intensiva de la Estética, Humanidades, Diseño, Psicología Perceptual, Semántica del Producto y Lingüística, para producir un marco integrado de términos a ser aplicados como instrumentos conceptuales tanto para el análisis como para la descripción explicativa del fenómeno. Esto implicó la ejecución de relevamientos y sistematización de archivos en diferentes repositorios institucionales como el Centro de Archivo histórico de la General Motors, el Centro de Investigación automotriz de Estados Unidos, la Biblioteca Universidad de Palermo, la Biblioteca FADU - UBA, Schreiner University, MIT Press y Academia. Adicionalmente la adquisición de ejemplares de textos de autores consagrados.

\subsubsection{Tratamiento de Datos}

Los datos colectados fueron procesados como análisis de contenidos verbales y visuales bajo las preguntas de investigación y las matrices de datos que guiaron el análisis correlacional, bajo la secuencia de:

1. Compilación de datos.

2. Organización por las categorías o indicadores establecidos en las matrices y segregación de datos no compatibles o irrelevantes.

3. Comparaciones e interpretación apoyado en el cruce de teoría y dato empírico.

4. Identificación de continuidades, particularidades, generalidades o compatibilidades con la teoría del Diseño industrial. 
5. Síntesis: Se produjeron diferentes tablas de síntesis, mapeos, esquemas (ver apéndices 4 a 7$)$.

6. Ejecución del escrito según capítulos determinados por el investigador en coherencia con la secuencia cronológica y proyectual de la praxis estudiada: pensar, actuar y producto desde una narrativa histórica que conceptualiza para hacer explícito el conocimiento que yace oculto e ilustra las evidencias empíricas que aportó el caso. (Ver apéndice 3 Tabla de Información colectada en GM Heritage Center).

\subsubsection{Población y Muestra}

Establecida la población como la praxis de los diseñadores de la General Motors para la serie Concept cars entre 1945 y 1965 en Estados Unidos.

La muestra procedió al estudio de modelos Concept car concebidos y concretados durante ese período, procurando contrastarles para encontrar particularidades, generalidades, conexiones para la constatación de las hipótesis.

\subsubsection{Diseño de la Investigación}

Esta investigación cualitativa que trata de la praxis de los diseñadores de los Concept cars de la General Motors en Estados Unidos entre 1945 y 1965 procura una caracterización conceptual de sus operaciones - productos y sus relaciones para reflexionar la agencia del diseño de la estética de su objeto: cuerpo del automóvil.

Juan Samaja (2004) señala que el principal presupuesto de toda investigación científica es que el objeto de estudio sea inteligible, esto es que sea posible describirlo identificando y caracterizando sus elementos componentes clave indagando en las relaciones que guardan entre sí. "El acto de describirla 'científicamente' es en realidad un acto de redescripción y por lo mismo es una forma de modificar nuestro conocimiento previo" (p. 149).

Esta caracterización estructura una serie de discursos descriptivos apoyados en fundamentos teóricos que facultan poner de manifiesto aspectos clave de la unidad de análisis central. Así las diferentes descripciones identifican y dan referencia a las diferentes dimensiones de las variables con que se orienta la búsqueda de los atributos y relaciones que luego darán cuenta de las hipótesis anticipadas.

Tratándose de una praxis compleja, en la que partimos de aceptar que el objeto estético es creado en el acto y por medio de las acciones de diseño, es condicionada por las circunstancias sociohistóricas del contexto y las determinaciones institucionales. Con los fundamentos teóricos de las Humanidades es posible indagar: desde dónde se diseña, para quién se diseña, en función de que valores ideológicos, estereotipos, imaginarios en el campo para comprender en la unidad de la experiencia espacio temporal cómo se desarrolla esa práctica de los diseñadores.

Para dar cuenta de la descriptiva de los elementos componentes del fenómeno y sus relaciones a través de los datos, adherimos a la propuesta del mismo Samaja quien indica que toda investigación determina un "sistema de matrices de datos". Dada la necesidad de fragmentar el objeto de estudio en unidades de análisis que en sí mismas constituyen un 'universo' y que a la vez, hacen parte de uno mayor dan lugar a sucesiones de configuraciones. Esas matrices de datos poseen un carácter según su relación: 
1. Matriz central de datos o del anclaje de la investigación, refiere a la Unidad de Análisis (UA) en que se focaliza el estudio. En nuestro caso la praxis de diseño de la estética de los Concept cars de los diseñadores de la General Motors de Estados Unidos entre 1945 y 1965. 2. Matriz de Nivel Subunitario una o más matrices constituidas por las variables de la (UA) del nivel de anclaje. En nuestro caso, son coordinadas y no subordinadas entre sí. No se pretende examinarlas como secuencia lineal o de prerrequisitos, sino de sus relaciones de interdependencia. Para nuestra UA identificamos tres: 1. Pensamiento estético. 2. Acto de diseño: operaciones - productos del diseñador. 3. Objeto estético: cuerpo exterior del automóvil Concept car.

3. Matriz de Nivel Supraunitario que corresponde a los contextos identificados de la (UA) y de sus variables; para esta praxis se identifica como Estados Unidos entre 1945 y 1965 y la institución inmediata, General Motors en el programa Concept cars.

Según el mismo Samaja, el dato posee una estructura cuatripartita y cuyos elementos compositivos referiremos apoyados en Ynoub (2015):

1. Unidad de análisis (UA): constituye el elemento central o foco de estudio.

2. Variables (V): constituyen las características, aspectos o propiedades que se han seleccionado para examinar la (UA). Estas poseen unas dimensiones como aspectos parciales de las variables. Sus valores en conjunto dan cuenta del valor de la variable.

3. Valores $(\mathrm{R})$ : constituyen aspectos particulares de las variables. Con relación a este análisis cualitativo, se procura una caracterización rigurosa y exhaustiva.

4. Indicadores (I): alude al procedimiento (s) que se aplica a alguna dimensión de la variable para establecer en ella qué valor de ella le corresponde a la (UA).

Para nuestro caso de estudio la unidad de análisis de anclaje (UA) praxis de los diseñadores de los Concept cars de la General Motors en Estados Unidos entre 1945 y 1965, con sus variables (V): 1. Pensamiento estético. 2. Acto de diseño de la estética del Concept car. 3. Objeto estético: cuerpo exterior del automóvil Concept car.

\subsection{Marco Teórico}

El propósito de este apartado es aproximar una caracterización del diseño estético del objeto para estructurar una plataforma conceptual que permita sustentar el análisis del pensamiento objeto de la praxis de estudio en su relación dialógica con su contexto pragmático y con ello develar fundamentos que hagan legible el conocimiento del Diseño para la producción de sentido estético en función de la interacción sensible del sujeto con el objeto.

La fenomenología como línea de pensamiento creada por el alemán Edmund Husserl (1983), que además nutre a la hermenéutica, se ocupa de observar fenómenos lo que aparece, lo que se brinda a la experiencia para describir de esos fenómenos visuales y constructivos, su esencia, la cual puede ser interpretada como la captación perceptual, empírica de cualidades de su apariencia y de los significados atribuibles por la lógica y el 
conocimiento: 'son las esencias las que se revelan a la conciencia' no se trata solamente de descripciones sensoriales y elementos psicológicos y empíricos de la realidad para reducirlos a unidades lógicas o estructuras, con lo cual descarta subjetividades venidas de las emociones y el modo en que las personas se relacionan con los objetos y con su entorno. Sí bien su orientación tiene una actitud lógica y metodológica de conocimiento, la fenomenología evoluciona en la observación de las condiciones de la experiencia en relación con lo que se experimenta en la dicotomía sujeto - objeto. Abordaje que nos permite crear el marco para indagar sobre la producción de una información como estética que se torna en una apariencia y aparecer para ser experimentada por el sujeto. Y describir diferentes categorías de formación de un pensamiento en acción en unas determinadas condiciones de experiencia para la praxis de los diseñadores en función del par sujeto - objeto.

La posición objetivista de Husserl limita la exploración del objeto como material empírico en tanto lo asume como unidad de estudio más desde la lógica. Por su parte, Merleau Ponty [1945] (2015) migra a lo corporal para acceder a la experiencia, abre la posibilidad de atribuir una serie de cualidades empíricas para hacer legible las interacciones que estas posibilitan a las personas y que las hacen distintivas de otras; así las propiedades formales para la captación sensible tienen un sentido y modo de experimentación diferente a otras que les otorgan los raciocinios lógicos, por ejemplo: un desempeño estructural frente a esfuerzos físicos. Luego, Verbeek, (2005) observa el papel de la configuración de condiciones de la experiencia mediada por la cultura material, indicando que los artefactos median en la objetividad y subjetividad de los seres humanos, su interés se centra más en los efectos de una 'estética material' es decir el impacto del objeto en la experiencia estética de las personas con su entorno material; con la primera se reconoce una aproximación lógica objetiva y con la segunda, se reconoce la construcción dada por la experiencia, donde el sujeto pone una sensibilidad además de conciencia en lo que experimenta y en el cómo lo experimenta. Uno de los aportes relevantes de esta perspectiva es que las personas y las cosas se configuran entre sí no sólo por su relación dialógica sino porque las personas añaden significados a los objetos mientras los experimentan (Verbeek, 2005; Sudjic, 2009; Norman, 2004; Folkman, 2013).

En su versión contemporánea: la postfenomenología integra fenomenología y pragmatismo; uno de sus principales exponentes Don Ihde (1990) anuncia su indagación de la relación del sujeto con el artefacto tecnológico en el marco del pragmatismo cuestionando el postulado de Husserl que califica de "relato objetivista ingenuo" (p. 97) en el sentido de que al limitar el estudio de la experiencia y lo experimentado a una mirada de raciocinio lógico que permite sólo una caracterización física, material del objeto, se ignora una correlación experimental previa y la naturaleza humana, sensible y subjetiva como complemento a la dicotomía central de la fenomenología: sujeto - objeto.

Entendiendo que, en el postulado inicial de la fenomenología de Husserl, sus nociones clave de noesis o acto psíquico, intencional, individual de pensar al objeto o acto de correlacionar y noema como el contenido de lo pensado o correlato, juntos hacen a la intencionalidad, ésta es entendida como un enlace entre un propósito de un sujeto consciente y el conocimiento que éste adquiere con la experiencia para lograr su objeto de acción. En el análisis desde la postfenomenología, se añade un componente reflexivo que no se fundamenta en lo determinado como entidades fijas, sino que, en una perspectiva pragmática, 
el individuo sortea ambigüedades, factores desconocidos o inesperados o modos particulares de experiencia. Entonces la noesis añade a lo psíquico y lo perceptual, el componente empírico y reflexivo, al noema la flexibilidad de variación en función de las condiciones de la experiencia.

Ihde sustenta la combinación de fenomenología con el pragmatismo en la línea de John Dewey (2005) donde la experiencia supone una participación interna del sujeto y no sólo mental para que el 'yo' pueda producir una relación con las condiciones del contexto y fluir en él y más aún, resalta la dependencia del contexto y una multidimensionalidad y variabilidad de circunstancias, condiciones que generan lo que llama la correlación existencial entre sujeto - objeto para configurarse mutuamente. Como entidades flexibles y cambiantes son entidades hermenéuticas en el sentido de que son interpretables como relaciones de alteridad y relaciones de fondo (Ihde, 2012).

Nuestra proposición es que el diseño de la estética del objeto constituye en sí mismo, un fenómeno 'algo que se revela por sí mismo y aparece bajo su propia luz', 'posee una estructura interna de funcionamiento que resulta de una correlación entre subjetividad y objetividad como de conocimiento antecedente o normado y otro que se construye con la experiencia entre sujeto - objeto en un contexto'.

Con este encuadre es posible caracterizarle observando la correlación experiencial del sujeto diseñador que además de actuar como intérprete posee una conciencia y subjetividad que guían su pensamiento intencional para configurar los contenidos que hacen al objeto y el modo de experimentarlo. En tanto estrategia de estudio del fenómeno implica analizarlo, encontrar sus particularidades y generalidades, desocultar su esencia en sus unidades significativas, las que construyen sentido para hacerlo comprensible.

En una primera instancia partiremos de postular el diseño de la estética del objeto como un pensamiento en acción performativo y relacional para la producción de una información cuyos contenidos estructuran un mensaje evocador, de novedad y contraste que es expresado en las cualidades de la manifestación material del objeto para que éste se capte desde la sensibilidad de las personas.

\subsubsection{Noción de la Estética en Relación con el Diseño}

El término 'Estética' del griego "aistetiké" de aisthesis: sensación, sensibilidad se asocia a la representación sensible de la experiencia humana con la obra. Diferentes autores, y algunas ideas en común permiten la siguiente interpretación: una intersección de apariencias sensuales y conceptos impregnados de significados del pasado y del presente que transfigurados por la imaginación ofrecen nuevas apariencias para la contemplación sensible y placentera de las personas de sí mismas y de su mundo (Lemcke, 1945; Bubner,1989; Genette, 1999; Zátonyi, 2011, 2002; Folkmann, 2013).

Marta Zátonyi (2002) la describe como "la esencia humana expresada sensiblemente" (p. 16) y abre diferentes posibilidades para la exploración de la Estética: en su obra Aportes a la Estética (2016) la refiere diciendo: "El mundo de las ideas es su lugar, pero pertenece por igual a la empiria de la materia, ya transfigurada por la forma. Entreteje lo general con lo particular, lo universal con lo eventual" (p. 9). Nada de lo humano le es ajeno y se abre solidariamente a múltiples saberes para ser complementada. 
Con foco en la estética, el Diseño suma a la razón y los sentidos, la sensibilidad. Esta capacidad de sentir emoción (afecto) ${ }^{13}$ desde una valoración personal de la realidad, de sus representaciones y de sus apariencias, suma el componente de subjetividad que le es propio a los individuos no sólo para percibir, también expresarse en su entorno. Esta subjetividad opera en el diseñador quien se posa entre la de los sujetos y su campo objetivo de operación para interpretar, articular y producir una mediación que además de narrar contenidos de su contexto de formación, provee rasgos de su propia ficción.

El fenómeno estético : "lo que aparece", "lo que se brinda a la experiencia" implica una dimensión ontológica y ética por su efecto en la sensibilidad, emociones de las personas, la configuración visual y material no sólo de los objetos en su dimensión utilitaria también como configuración del entorno que da cuenta de las raíces socio culturales e históricas en que esta se crea, la proyección de preferencias, deseos e imagen de los sujetos y la voz del creador en el mensaje de la materia figurada.

En el mismo marco de la postfenomenología, la Estética empareja el componente de subjetivización con el mundo objetivo en que opera el diseñador y plantea una relación activa del sujeto receptor con la información de apariencia del objeto; esto es particularmente relevante por cuanto la creación estética trata de la creación simbólica intencionada para que el receptor experimente forma y contenido. Al dar lugar a la interpretación, se promueve un espacio activación de curiosidad, de imaginación y puesta en juego de memorias propias para que conecten con lo que allí aparece y el receptor complete los contenidos. El diseñador requiere ver la dimensión ontológica de su entorno: determinaciones sociales, valoraciones y representaciones materializadas que reflejan la subjetividad de las personas para tomar de allí voces que se van a hibridar con su propia narrativa.

Zátonyi (2002), señala que debe distinguirse también que sujeto y objeto como fenómeno articulado existen de manera independiente, diferenciada; el sujeto necesita trascender, generar conciencia. El sujeto es el cognoscente, el objeto es lo conocido. Un objeto es algo pensado con sentido, de lo contrario desaparece de la atención del sujeto, pero es el objeto el que vitaliza la experiencia estética, la percepción sensible y la captura de conceptos que hacen también al contenido del objeto.

Adherimos a la noción de experiencia estética de Seel (2010) como una experiencia "que no sólo constituye una entrada a lo real, sino también un paso hacia sus confines (...) en donde las representaciones estéticas son sensibles, no son percepciones, pues no refieren a un presente actual sino a un presente ausente" (p. 111).

Para pensar el rol creativo del diseñador, en este fenómeno articulado hay además una relación jerárquica e intencionada. Hay un sujeto empírico que sigue lo existente y un sujeto trascendental o transformador que enfrenta las tensiones entre continuidad y discontinuidad; entre una verdad universalmente adoptada versus nuevas experiencias que se salen del esquema y son apreciadas de irracionales o descontextualizadas. Ello supone un balance entre lo objetivo y lo subjetivo para que la articulación de raíces, ideologías, patrones y valores migren a una construcción singular y autorreferente que se convierte en una intersección atractiva y de resonancia emocional para las personas y el diseñador. Para la Modernidad, el hito de la Estética se vuelca hacia la subjetividad en el sentido del sentir, pensar y percibir del receptor y el pensar, sentir, hacer del creador que se expresa a través de la obra, juntos en un papel activo frente a la creación y a la apreciación generan 
una mirada de la Estética que pone mayor foco en la resonancia emocional respecto de la discusión sobre la obra (Oliveras, 2005). Zátonyi (2002) añade que Estética y Diseño en su creación satisfacen necesidades que viajan al mundo sensible de las personas, pero también a contar historias que hablan de las ideologías, las relaciones sociales, la conexión de los individuos con su entorno; por lo tanto, no se trata de un goce estético solamente sino de la expresión o testimonio de la trayectoria humana. En lo que respecta a la creación plástica una bella expresión se traduce en lo que resuena en las personas, luego puede observarse que su concepto y los atributos de su composición, son adecuados (Bubner,1989). La belleza provee sensación gratificante sin que su fundamento sea el entendimiento de su estructura en el receptor. Parafraseando la noción de Santo Tomás de Aquino Belleza es lo que hace un objeto sea bueno para observar. La belleza es el resplandor de las cosas bien informadas que satisfacen ricamente nuestro deseo cognitivo. Es lo que da placer a la vista, sugiriendo alegría inmediata sin razonamiento intermedio frente a la imagen, o nos gusta a primera vista o no nos gusta.

Lobach (1973), afirma que el diseño industrial es un proceso de adaptación estética del hombre llevado a una escala industrial, con compromiso en su adaptación a necesidades físicas y psíquicas del usuario, el diseñador tiene a su cargo la definición de funciones comunicativo - simbólicas en el objeto. Acuñando el término estética de valor alude a un conjunto de valores formales que dan cuenta de la conexión con lo normado y preferido socialmente, valoración que es posible por la estética empírica en la que devela un modo de co-creación entre el diseñador y los sujetos para captar de ellos sus respuestas y apetencias. Por último, combina el componente objetivo, de leyes compositivas y el subjetivo del diseñador que con sus habilidades artísticas otorga una dimensión plástica a su composición. Por su parte, Gillo Dorfles, en su libro El diseño industrial y su estética (1968) expone que: "el diseño industrial como una disciplina en desarrollo (...) íntimamente vinculada a la elevación física y mental del nivel de vida, el desarrollo de la producción y el acceso a una existencia más humanizada" (p. 5), genera una especie de forma artística, la cual contiene sorpresa, novedad (sin ella no captura atención y pierde su valor estético), rasgos aspiracionales y de refuerzo del gusto, alcanzando una esteticidad, que comporta una dimensión de significado antropológico. Con un carácter antropológico de la dimensión estética el asunto de belleza ha sido desplazado por el que se ocupa de la conexión sensible con la forma, tomando como aspecto clave la posibilidad de una proyección sensible del sujeto en la imagen contemplada, una suerte de identificación ya sea de una conciencia presente o idealizada pero que, en todo caso para la creación, suponen la representación de significados que activen el vínculo y con ello una orientación más subjetivista e interaccionista con las personas que de imitación de referentes.

Desde una mirada más sociológica - antropológica Bourdieu (2010) y Sudjic (2009) tienden pistas para ver la estética del objeto como una producción de significados y rasgos de representación de valores de identidad e ideología que exceden la noción de mercancía del objeto y le convierten en una mediación para la conexión intersubjetiva del sujeto para su proyección social, entonces las cualidades estéticas en sus propiedades comunicativas representan aspectos del capital simbólico de la sociedad. En su naturaleza dinámica gusto y juicio de apreciación hacen un fenómeno que cambia en el tiempo. Rams (2009) ofrece una concepción del diseño como expresión de verdad interior y cruzamientos entre lo 
socio cultural y tecnológico para producir un significado intencional en la configuración formal, que lejos de ser arbitraria es portadora de imagen y de esencia del entorno; un contenido simbólico que debe ser fácilmente comprensible.

Para el diseño de la estética del objeto, se trata de su forma y contenido o mensaje que fusiona ideas, representaciones y patrones precedentes para crear una expresión nueva. Una mediación para la experiencia estética con un sujeto intérprete, imaginativo con sus propios prejuicios quien está localizado espacio temporalmente y con un bagaje particular acerca sus propias representaciones y preferencias, acordes a la categoría funcional y a sus propias idealizaciones. El diseñador trama esas imágenes, ideas de información externa e interna, real e imaginada que deben intersectarse en una apariencia y aparecer de conexión cercana y fascinante.

La Estética con relación al diseño entonces, puede aproximarse como una plataforma conceptual que le sitúa en su expresión sensible, en la concepción de las condiciones de mediación y de la experiencia sujeto - objeto como un par que se configura mutuamente con relación al contexto. La Estética marca una naturaleza relacional de la intención y producción del diseño subjetivo - objetivo para que se capte la esencia intrínseca o mensaje comunicado en la forma y no sólo las cualidades de su imagen externa, esto compromete al diseñador a ser el primer sujeto de experiencia estética para luego poder comunicarla.

\subsubsection{Hacia una Idea del Pensamiento Estético del Diseño}

Una primera idea de pensamiento como acción interiorizada de Jean Piaget lo vincula a la formación de esquemas que como asimilaciones de las representaciones de la realidad son también elaboraciones particulares, constituyen la percepción de un fenómeno del mundo que rodea la experiencia y una consiguiente asimilación interior. Con la intervención del ego Piaget remarca el carácter único de formación de pensamiento bajo los sesgues individuales y la imposibilidad que una misma realidad o concepción sea asimilada de manera idéntica por dos o más personas. Sin embargo, al diseñador no le basta con ello, requiere relacionarse con otros pensamientos (previos y presentes) para producir un nuevo esquema, de lo contrario resulta ajeno a otros y se estanca.

Zátonyi (2002) asimila esa noción de 'pensamiento egocéntrico' acuñado por Piaget como una acción práctica de recorte que da lugar a un pensamiento empírico unilateral; solo valiéndose de otras ideas elaboradas, del mundo y sus componentes de conocimiento puede traducirse en un pensamiento operativo o en acción para tornarse en una expresión con sentido.

Para Breyer (2007) en el marco del Diseño, el pensamiento se trata de una construcción mental que reúne tanto concepciones (del conocimiento formal) como del resultado de abstracciones de la realidad y de la imaginación. Mientras que Bruner (1988) distingue un 'pensamiento formal' basado en el pensamiento lógico, que suele ser más explícito y uno 'narrativo' que se alimenta de una percepción e interpretación subjetiva del entorno, del bagaje adquirido con las experiencias que de orden más tácito hasta que no se exterioriza intencionalmente como relato. Con ambos se combina tanto lo objetivo como lo subjetivo, también lo ya comprobado con lo que también es imaginado y modelado de manera singular. 
Cornelius Castoriadis (1999) ofrece en su pensamiento, bases clave para reflexionar una mirada ontológica del diseñador cuando pone en juego la estrecha relación de la capacidad imaginativa de los individuos y su acción social transformadora. Vinculando teoría y práctica como binomio inseparable para comprender el fenómeno histórico-social lo asimila como una creación humana que va construyendo un conocimiento en continuo que dota al individuo reflexivo de una conciencia para transitar hacia la autonomía y no sólo hacia la reproducción de los imaginarios. Los imaginarios y la imaginación son nociones centrales en su postulado: con los primeros refiere: "Decimos imaginario cuando queremos hablar de algo 'inventado' ya se trate de un invento 'absoluto' (...) o de un deslizamiento, desplazamiento de sentido, en el que unos símbolos ya disponibles están investidos con otras significaciones que las suyas normales o canónicas" (p. 139), interpretables como significaciones y representaciones simbólicas que se instalan en la sociedad. La sociedad constituye un orden simbólico a través de las instituciones y de los individuos que puede ser inconsciente y no controlado pues le es imposible a los individuos captar de una vez y para siempre todo o prever sus consecuencias, por ello la esencia del Ser es indeterminada y caótica como lo son sus creaciones. En referencia a la imaginación como la habilidad que permite al sujeto abstraer parte de los encadenamientos simbólicos de su entorno y de significaciones que a través de una creación se torna en una manifestación exterior, física dada a los sentidos y por la imaginación un mensaje simbólico con sentido de conexión voluntaria que sólo es posible a través del lenguaje. Para Castoriadis la historia no existe sino en y por diferentes tipos de lenguaje que son transformativos en función de la génesis de sentido que las personas otorgan a su existencia.

Con el encuadre postfenomenológico y de la Estética que son extrapolables al pensar del diseño podemos interpretar que el pensamiento estético se inscribe más en un pensamiento dialéctico 'arte de la conversación entre dos', esos dos como ya se ha mencionado son un par activo que se complementa pero también pone en tensión su propia internalización; en el plano de la apreciación estética, la retroalimentación sobre la apariencia, apoyada en el gusto aporta al diseñador una nueva entrada para un nuevo esquema de forma y contenido. Sí se tratará solo de un pensamiento desde el positivismo, se trata de un orden impuesto y mensurable desde de la composición en sí más que de la experiencia sensible y subjetiva. Con un pensamiento dialéctico el diseño de la estética del objeto reconoce la alteridad y pone en interacción su mensaje y con ella un ciclo de iteración o ciclo que se renueva en cuanto más se expone. Poner lo dicho y recoger lo que el otro tiene que decir sobre ello, nutre su creación. El pensamiento requiere del lenguaje porque con éste la representación interna es exteriorizada: significaciones, símbolos pueden ser contados e interpretados por otros. En tanto estética del objeto combina contenidos y una materia organizada que a menos que otro la lea se reduce a una entidad física ignorada. Así que debe dotarse de relato y de códigos reconocibles para su conexión.

\subsubsection{Dimensión Comunicativa del Diseño de la Estética}

Esta dimensión refiere a la comunicación del mensaje y cualidades estéticas otorgados a la estructura de información del objeto: conexión de conceptos de su categoría funcional y su apariencia atractiva. 
Grant Kester (2004) aborda la naturaleza comunicativa de la producción estética haciendo énfasis en que no es en sí la narrativa concretada sino la intención de resonancia que ésta produce en las personas, su asunto central. En línea con Habermas enfatiza en que la habilidad del creativo para estructurar una composición que sigue reglas implica también, reconocer una vulnerabilidad intrasubjetiva del receptor para resistirse al mensaje o para dejar que se moldee su subjetividad; en ese sentido un contenido o relato no sólo refiere a una herramienta para comunicar conceptos ya formados sino para llegar a la sensibilidad. Esto precisa situar el mensaje en la condición específica del que lo recibe e interpreta; entonces la comunicación pertenece a un contexto tanto de formación como de interpretación donde el contexto tiene una fuerte implicación en la apreciación de los significados que circulan entre el mensaje y quien los capta. El diseñador que conoce adopta un rol constructivo crítico de los imaginarios y significados para producir sus contenidos. Tratándose del mensaje estético, se compromete con una estructura conceptual que otorga carácter sensible al binomio belleza -utilidad y a un relato simbólico que procure mover la imaginación.

Para ahondar en sus claves, acudiremos a la Hermenéutica. Según Wolfgang Iser (2005) la hermenéutica como el arte de la interpretación, esta acción comunicativa y estética es vista como un "proceso de traducción en que se transforma algo en otra cosa" (p. 29). Como estética, se trata de un movimiento entre la polaridad sujeto - objeto donde el significado estético se posa en el medio para desatar un acto interpretativo; el sujeto llena los espacios que la obra genera como espacios intencionales de una lectura para la construcción de sentido.

La dimensión comunicativa de la obra debe habilitar la condición humana de ficción; para Iser la ficción literaria es la construcción de otras posibilidades de realidad, allí se hable de lo que pudiera o debiera existir, también alude a una verdad o mensaje tácito que el lector debe descubrir y señala que el texto debe ser polisémico, multirreferencial, no para complejizarlo sino para despertar el interés y mover la fantasía. En esta interacción, el texto es una interfase provocadora que delinea un rol activo del receptor con un pensamiento imaginativo, un juicio y un medio para lograr placer. La sensibilidad complementa el entendimiento y estimula la búsqueda de la esencia del mensaje, aunque esté sólo se insinué, también con la subjetividad, el intérprete inicia su lectura con la preconstrucción de un sentido potencial que luego intentar constatar mediante asociaciones.

Un proceso recursivo en el que el sujeto procura la equivalencia con memorias propias, rasgos, significaciones con las que se pueda identificar. Por último, en su distinción de dos polos para la interpretación, el artístico es atribuido a un creador que estructura la narrativa y el estético, otorgado al lector quien en últimas efectúa su apreciación.

Entre el sujeto - apariencia del objeto circulan contenidos de conocimiento antecedente, de la voz del diseñador y de ficción para que se convierta en una expresión singular con esencia interior que espera a ser vivificada por su receptor.

La enunciación de 'interfase provocadora' provista por Iser constituye un instrumento conceptual de enlace con la teoría del Diseño de uno de sus exponentes: Gui Bonsiepe ${ }^{14}$ (1993) quien, en su entendimiento del diseño industrial como el desarrollo de una interfaz, plantea un esquema ontológico del diseño, el cual está conformado por tres componentes que se relacionan interdependientemente entre sí: 1 . El sujeto agente social y usuario 
como alguien que ejecuta una tarea. 2. La tarea a realizar. 3. El artefacto que además de ser un utilitario es un modo de extensión humana para la ejecución de la actividad. En su noción la interfaz más que un objeto una articulación de interacción de los tres componentes. El diseñador no centra su atención en la composición de un objeto aislado sino un medio que debe articularse eficiente y significativamente al sujeto y su hacer. En clave estética, esta interfase es una articulación de información, para la interacción del sujeto con el contenido funcional y de las cualidades de carácter sensible que el diseñador concibe y concreta para mediar la experiencia estética de los individuos y extender la percepción de lo útil del objeto a una resonancia emocional de su belleza funcional expresión acuñada por Harley Earl en su comunicado "Harley Earl to Inter-organization letters only, Styling Division, Field where designers operate. Concept car Le Sabre Project. 16 January 1953, New York General Motors Corporation, New York City".

\subsubsection{Información como Forma}

El término "información" del latín informatio está conformado por el prefijo in: hacia dentro, y el sufijo formatio: acción de dar forma. Como expresión performativa enuncia la configuración de una estructura que inicia afuera y que transita hacia dentro, una colección de datos externos que bajo un proceso que pasa por discriminación, asociación, articulación, organización y síntesis, el diseñador traduce en un contenido no sólo comprensible por su referencia al contexto en su significado estético sino como enunciación con carácter de referencia singular.

En el marco de comunicación, el significado está asociado a una construcción socio cultural de enunciación de algo con palabras que un colectivo interpreta como tal, de manera consensuada, también a un concepto que evoca un conjunto de rasgos con los que un fenómeno o entidad pueden ser comprendidos. Identificamos cinco características aplicables al diseño: 1. El significado es un espacio estructurado. 2. Una trama de sentido intencionalmente construido. 3. Un conjunto de rasgos que delimitan un espacio de comprensión e identificación. 4. Una mediación que guía la agencia de un individuo. 5. Un recurso de interacción dialógica que pone rasgos para el entendimiento sin que ello limite una autonomía para nuevas rutas de interpretación (Krippendorf, 2006). Y añadimos: un espacio de articulación de significados previos relativos al juicio estético con otros correlacionados y novedosos para la experiencia estética.

La información para dar forma estética requiere además de otros significados que parten de comparaciones relacionales y críticas de referentes: contraste y novedad. Acorde con Coates (2003) toma del término: revitalización de la estética ${ }^{15}$, el contraste y novedad como propiedades clave para la experiencia estética. El contraste es un modo de incongruencia o discontinuidad de patrones, se da por la presencia de oposición entre elementos cercanos. Su valoración es asociada a la dinamización de la percepción y a un modo de sorpresa. Su opuesto, la regularidad presenta una sucesión de los mismos elementos en sus figuraciones, escalas, proporciones y que se asocian más a la necesidad de guiar al receptor en su accionar más que en promover sus emociones. El diseñador entonces juega con variantes de figura, tamaño, color, dirección, textura, posición o dirección en función de captar la atención y emoción de las personas. 
Con referencia a la novedad se parte de conocer la idea que se tiene de algo, un estereotipo o esquema mental que hace que las personas en su ojo y cerebro estén predispuestas a una determinada información para a partir de allí, poder producir una innovación semántica (o figurativa): un concepto subjetivo que desliza el sentido o el campo de aplicación de destino y no necesariamente su significado de origen. La novedad implica relacionar estructuras de significados enraizadas en la cadena de interpretación y valoración para generar modelos mentales que no existen, por lo tanto, son inesperados y tienen cierto grado de incertidumbre o indeterminabilidad. Asociada a la sorpresa, la novedad requiere cierto grado de enlace a referentes que pueden ser conceptuales o simbólicos para evitar ser rechazados. Con relación al juicio estético una misma apariencia armoniosa y bien resuelta configurativamente, es bella para alguien con más información de diversidad estética que para otra que la juzga de fea por no adecuarse o correlacionarse con patrones incorporados. Es decir, las propiedades se vinculan al prejuicio, pero también pueden crear nuevos. Un recurso de su expresión son las metáforas tanto verbales como visuales, en su fuerza expresiva, su sentido es dado de manera inconsciente y por lo tanto proporciona una comodidad perceptiva, que para la Psicología se trata de un sentimiento adimensional en el que la determinabilidad y la indeterminabilidad coexisten sin desafío de explicación. Lakoff y Johnson en su trabajo Metaphors We Live By (1980) afirman que estas constituyen una forma de integración conceptual que impregna la vida cotidiana y conforma un esquema mental con que las personas van acumulando imágenes, significados con la posibilidad de que estos sean transfigurados por la imaginación. Como innovación semántica tienen la propiedad de evocar una cosa por otra con su valor simbólico; una abstracción de un dominio de origen con cambio al dominio de destino. Con estas figuras retóricas el diseñador posee un recurso de estimulación directa y por lo tanto un relevamiento de lo sensible sobre el entendimiento.

\subsubsection{Forma y Contenido}

El acto de creación estética suele partir de ideas difusas, de conceptos ausentes, de información ajena e inconexa que espera tomar 'otra forma, otro contenido' mientras se construye. Se trata de fusión entre lo externo al diseñador y lo interno como bagaje desde su experiencia personal; un ciclo que se renueva con la experiencia y el intercambio entre lo proyectado y lo que retorna como retroalimentación.

La forma como estructura sinérgica de elementos, existe en cuanto es contenido (esencia) que toma forma en una materia organizada que se vitaliza por lo que expresa y conecta con el sujeto. En un sentido hegeliano 'la materia debe tomar forma y la forma ser materializada' porque a través de la forma materializada, surge la apariencia y es esta la que exterioriza la esencia o contenido de la creación: el mensaje expresado (Zátonyi, 2002). El diseñador agencia la información en una estrecha relación con su campo intelectual, procurando una producción retórica y de figuración en una estructura abstracta que contiene elementos de significación, simbólicos y de la plástica como fusión de los datos del contexto fenomenológico y de sus propias ideas para la producción de un mensaje autorreferente; con lo cual su propuesta estética adquiere un carácter de singularidad y de balance entre familiaridad y novedad. 
El contenido va a ser tratado desde tres dimensiones: 1. Idea estética. 2. Hibridación. 3. Complejidad. 4. Ética estética.

1. En tanto idea estética es una representación de la síntesis ocasionada por la imaginación donde sensibilidad y entendimiento operan de manera inconsciente, una expresión subjetiva del diseñador que anticipa el carácter distintivo del mensaje a proyectar en la forma total (puede referirse a la realidad exterior y al mismo tiempo a la realidad interior del diseñador, un fenómeno a representar, rasgos del carácter personal migran a la historia que se va a contar); orienta la narrativa o esencia interior, posee rasgos de ficción es decir la anticipación de algo que no existe, un grado de novedad. En palabras de Zátonyi (2002) “(...) el tema no puede carecer de lo empíricamente no existente, de la ficción (la creación de otra realidad). Y nunca puede ser tan ficticio el tema que alguna parte suya no tenga un anclaje en el suelo de la realidad objetiva" (p. 249). La idea transita entre una abstracción mental, una imagen y o un concepto; sugiere una línea delgada entre lo invisible - latente y lo visible - legible.

2. Con la hibridación se sugiere una mezcla de diferentes contenidos que pueden ser heterogéneos pero compatibles para dar lugar a uno nuevo que es autorreferente (da cuenta de su singularidad) y referente (conserva raíces de origen: patrones, significados). Con la hibridación lo relacional para estructurar la información: 'dar forma' se pone de manifiesto, y el diseñador requiere poner en balance lo objetivo con lo subjetivo, lo ficticio con los anclajes que conectan con las personas y las estructuras funcionales. El acierto de la hibridación radica en su adecuación entre de lo que dice y su aptitud para conectar de manera sensible. El diseño de la estética es un acto de creación condicionado y nutrido por múltiples datos de información y de diferentes voces.

Para el diseñador esa hibridación supone abstraer representaciones que están afuera e internalizarlas para estudiar en profundidad ideas, patrones precedentes que puedan ser fusionados para producir algo nuevo.

3. La complejidad está ligada no sólo a la multiplicidad de datos y sus variaciones, también a la imposibilidad de considerar todas las representaciones de la realidad que además es cambiante y condiciona la experiencia estética. Esta condición cambiante, establece un campo de complejidad para el acto de diseño. Edgar Morin en su trabajo de Introducción al pensamiento complejo (1990) dice que la complejidad es un "tejido (complexus: lo que está tejido en conjunto) de constituyentes heterogéneos inseparablemente asociados y que presenta la paradoja de lo uno y lo múltiple" (Morin, en Aman, 2015, p. 55). Su definición sugiere una idea de cohesión, de amarre; sin embargo, con ella no es posible no deja claro cómo encarar la imposibilidad abarcativa de la información. Por su parte, García Rolando (2013), entiende que "un sistema complejo es una representación de un corte (...) de la realidad conceptualizado como una totalidad organizada" con esta noción, entendemos que se requiere una abstracción en lo heterogéneo de la realidad para tomar algunos aspectos particulares que puedan ser sintetizados e integrados como referencias y conceptos a ser confrontados (con otros saberes, puntos de vista, arquetipos o estereotipos, bagaje propio e imaginación) y formar una unidad fundamental con sentido. A ese proceso de 
observación e interpretación que combina lo cognitivo con lo sensible; lo objetivo y lo subjetivo para ser llevado a una matriz de síntesis, la denominamos esquematismo. Su resultado es una síntesis de una multiplicidad de datos que precisa ser homogéneos para su comprensión y que entonces son agrupados como categorías y llevados a conceptos.

4. Así que el diseñador, quien se mueve entre lo que ve y no ve en función de la concepción estética, se pregunta: ¿y cuál recorte de lo que hay ahí afuera? Una primera respuesta obedece a parámetros entre lo objetivo o normado y a los subjetivo que reside como información interior, habilidades proyectuales y una propia intuición. Otra, y que se considera relevante para este trabajo es la que reclama de este individuo sociohistórica y culturalmente construido una posición ética frente a esa realidad física, mental y sensible en la que opera y de la cual abstrae una información que internaliza para luego devolverla como fusión y anticipación de algo nuevo como mediación y como modo de experiencia. Para explicarlo, acuñaremos una expresión ética para la estética partiendo de que "ética" del griego ethos: carácter que se forja en la intersubjetividad ${ }^{16}$; equivale en el marco de nuestro fenómeno, un conjunto de predisposiciones que van a forjar el carácter de un mensaje que reconoce la alteridad para que su experimentación sensible ofrezca una intersección entre las valoraciones de otro y lo que el diseñador intenta expresar. Con la ética estética procuramos resaltar que esta concepción que el diseñador hace está en función de otro, de unos precedentes que han sido asimilados y que marcan una serie de valoraciones que el diseñador debe conocer y comprender para tejer una trama que refiere y que ofrece un excedente de singularidad. Esto nos resulta relevante porque con la interfaz estética como mediación de la experiencia humana el diseño tiene una repercusión sensorial, mental, física y emocional en las personas (Norman 2004; Folkmann, 2013; Zátonyi, 2002).

En síntesis, la idea estética equivale a una representación de la imaginación en la que el diseñador expresa su propia voz, con la hibridación incorpora referentes de algo que existe o que aún no existe facultando la ficción y la metáfora, con la complejidad, el diseñador entiende las limitaciones de abordaje y la necesidad del intercambio y la correlación; luego con la ética estética, su concepción estética desliza lo intrasubjetivo a lo intersubjetivo que reconoce a otro con el que se produce la co-creación.

\subsubsection{Carácter Performativo del Diseño}

La performatividad envuelve acción y expresión de naturaleza subjetiva y evocadora para quien la recibe, pero un ejercicio de integración de valores de realidad presente y pasada para ser transformados en un nuevo mensaje.

El término performatividad, es inicialmente acuñado por el filósofo estadounidense John Austin hacia 1962 para designar expresiones que en sí mismas son una acción. Como tal permite producir una o más realidades a través de una enunciación evocadora, subjetiva, para que el receptor le otorgue sentido (Barthes, 1994).

Las expresiones performativas no son ejercicios libres, desvinculadas de la realidad o de su memoria. Repiten rasgos de tradición o convenciones sociales para que se les otorgue valor, tienen rasgos de repetición, pero incorporan singularidades para que se aprecien como 
otro o nuevo acontecimiento. Ya sea como palabras o expresiones, es el contexto quien les faculta como promotoras de nuevas realidades (Derrida, 1989).

La expresión diseño es en sí performativa; como sustantivo es manifestación del resultado de un proceso mental o concretado materialmente, aludiendo a la acción es un proceso transformativo que transita desde lo mental a lo material para ordenar la experiencia, para articularse con el mundo de los sujetos y desplazarlos hacia nuevas realidades.

El lenguaje en su dimensión performativa es un acto que produce efectos en la constitución del sentido que los sujetos dan a los fenómenos que perciben en su cotidianidad y aquellos que también constituyen sus patrones de identidad y preferencia. Esta dimensión performativa puede trasladarse como un aspecto central en el diseño de la estética del objeto y la resonancia emocional como el efecto que se produce en las personas a través del mensaje simbólico, metafórico, expresado en las cualidades de su manifestación material pero también de lo que ellas ya han incorporado antes. Las expresiones performativas no son ejercicios libres desvinculados de la realidad o de la memoria, requieren repetir rasgos de tradición o convención sociales para que se les otorgue valor (Derrida, 1989).

Tratándose de un acto de creación que no es totalmente libre ejerce la autonomía para la construcción de su ficción y valor identitario. Son referentes porque se corresponde a una estructura normada socialmente que le otorga sentido y le avala. Como expresión y manifestación que toca a la memoria filo y ontogenética reclama una posición ética de posicionarse frente a una verdad determinada, unas raíces o modelo normados para reproducirlos como una forma de subordinación dialéctica o plantearse ofrecer una propuesta que además de reconocible propone la simbolización de otras realidades. Entonces la expresión estética es un modo de lenguaje de realidad simbólica, cuya lectura se experimenta a través de los sentidos, la imaginación y la sensibilidad a partir de su contacto empírico, para luego tener un saber sobre esa realidad.

Transitando de las ideas a la acción de concretarlas produce efectos inmateriales y materiales. Para el caso del diseño, produce expresiones enunciativas y provocadoras para la experiencia subjetiva y sensible que se vehiculizan en la imagen del objeto. El sentido estético del diseño está conectado con la intersubjetividad del individuo y su voluntad para captar no sólo la forma visible y palpable, sino también su contenido latente e invisible, ello implica poner en juego los sentidos, la sensibilidad y el entendimiento. Con los dos primeros hay una estimulación que remite a las emociones, con el segundo, un reconocimiento de patrones, representaciones, arquetipos asimilados para su identificación y apreciación. Para el diseñador implica captar información de la realidad física, mental en la que circulan imágenes, ideas, preferencias asociadas a valores de identidad, significados o prácticas aprendidas. Esos datos captados deben organizarse en una estructura de contenidos que también sean autorreferentes al tratarse de un acto único ejecutado en circunstancias particulares, constituye su propio carácter y estructura de concepciones de una nueva realidad.

1.4.6.1. Lo que muestra la Imagen

Hemos dicho que con la performatividad la estética del objeto es una expresión enunciativa y evocadora. Esa expresión es la representación de un tipo particular de creación articulada de elementos portadores de sentido y cualidades que pueden ser percibidos como 
imagen. La imagen es el punto de inicio para la conexión, una constitución o soporte que puede ser percibido para su comprensión, también para su goce porque muestra atributos en su superficie que refiere a las relaciones internas de estructura y a la multiplicidad de lo que muestra. Para el caso del objeto se inscribe en una imagen material sin que ello anule su condición de imagen mental en tanto ofrece rasgos que animan la curiosidad y fantasía del observador.

La imagen tiene una doble condición posible de expresión: de presentación cuando su referencia figurativa comporta una codificación asociable a un significado, por ej.: la categoría funcional automóvil con una figuración arquetípica reconocible. Y es representación en cuanto a la designación de elementos que no pertenecen al mismo tiempo al significado en cuestión, por ej.: automóvil, sino que remite a otra cosa; es decir se desliza a la simbolización de naturaleza metafórica con intensidad evocadora que en todo caso posee rasgos de presentación para que sea de fácil comprensión. Seel (2004), menciona que un objeto se identifica en una imagen como semejante a otro sí puede ser analizado usando los mismos predicados clasificatorios. Su validez como representación en tanto signo que refiere en menor o mayor grado a semejanza con los elementos o cualidades plásticas que se distinguen en él: figuras, proporción, detalles distintivos que permitan su relacionamiento.

La imagen puede referir a algo que es o no es porque son abarcables no solo con la mirada del ojo, también de la mente. El objeto presente en el mundo siempre refiere a algo; su superficie es un medio de diálogo y una fuente de correspondencias a partir de sus atributos apreciables ya sea en proporción concisa, de saturación, de semejanza. La imagen como sistema es una unidad de carácter sensible que permite su apreciación en cuanto a su aparecer en conexión con lo social y cultural para que se le otorgue sentido y ahí, radica su valor de fantasía (Seel, 2004).

Además del sentido que las personas otorgan a la imagen como portadora de un mensaje y de unas cualidades de presentación y representación, la imagen posee una naturaleza fenomenológica porque es un aparecer ante el sujeto en un espacio tiempo determinado; un fenómeno que al mostrar mueve los sentidos, la cognición y otros procesos en cuanto evoca otras imágenes de valoración sensible.

Entonces lo que muestra la imagen no sólo tiene que ver con la figura exterior y la materialización que la hace tangible; muestra un tipo particular de estructura esencial interna y de su presentación.

\subsubsection{Carácter Relacional del Diseño}

El sentido de la estética del objeto es el diálogo con el sujeto desde su sensibilidad e imaginación más que con el entendimiento. Un juego donde la imagen del objeto (expresión performativa) activa el interés y la libertad del receptor para encontrar una forma de representación que armoniza consigo mismo (a). En su pensar - actuar del diseño para la estética del objeto comporta un intercambio entre el diseñador y el contexto en el que ejecuta un encuadre de la realidad, el cual alimentará su producción imaginativa y faculta una expresión performativa que posee valores compartidos con los individuos. Esto implica para el diseñador, articular lo sociológico-discursivo (identificación de sujeto con 
discurso ideológico y convenciones sociales), lo referencial-expresivo (referentes y representaciones que modelan fantasías y preferencias) y la experiencia estética (interacción placentera - subjetiva del sujeto con el objeto para otorgarle su propio sentido).

Adicionalmente, el diseño para la estética del objeto implica encadenamientos de significado de la información obtenida que le lleven de datos difusos e ideas inconexas a un sentido estético. Una confrontación de sistema de referencias y la construcción de nuevas o fusionadas. En tanto la información producida, la forma es una estructura sinérgica de contenidos es una trama de relación de interdependencia de elementos que poseen una esencia individual pero que conectan como unidad armónica. Como experiencia estética: una relación dinámica de un sujeto con la intención de ver y percibir algo como estético y un objeto con ciertas cualidades estéticamente codificadas (Genette, 1999). El mensaje estético no puede darse sí no es fundado en una relación codificada susceptible de ser interpretada y comprendida; como articulación de significados previos, conceptos diseñados e intención de aprehensión por alguien contextualmente localizado.

Desde una mirada sociológico - antropológica, Bourdieu (2010) y Sudjic (2009) tienden pistas para ver la estética del objeto como una producción de significados y rasgos de representación de valores de identidad e ideología que exceden la noción de mercancía del objeto y le convierten en una mediación para la conexión intersubjetiva del sujeto para su proyección social, entonces las cualidades estéticas en sus propiedades comunicativas representan aspectos del capital simbólico de la sociedad. En su naturaleza dinámica gusto y juicio de apreciación hacen un fenómeno que cambia en el tiempo. Rams (2009) ofrece una concepción del diseño como expresión de verdad interior y cruzamientos entre lo socio cultural y tecnológico para producir un significado intencional en la configuración formal, que lejos de ser arbitraria es portadora de imagen y de esencia del entorno; un contenido simbólico que debe ser fácilmente comprensible.

\subsubsection{Dicotomías: Pares Estructurales}

Con la noción de complejidad, aludimos al desafío ético del diseñador para hacer un recorte de la realidad y sustraer de allí datos precedentes que puestos en relación con los internalizados por el diseñador entran a la proyección imaginativa para anticipar algo nuevo, no en el sentido original sino como fusión singular de lo referente y una construcción única - singular. Producir la forma en su concepción estética implica, además, reconocer y poner en balance una serie de pares polares o dicotomías ${ }^{17}$ que yacen en la naturaleza misma del fenómeno y que en tanto opuestos son complementarios y estructurantes, por ej.: teoría - práctica, sujeto - objeto, subjetividad - objetividad.

El diseñador los identifica como tensiones y los lleva a un análisis relacional que es crítico, algunas de las relevantes: individuo - colectivo: una tensión entre el valor de lo interno, singular y subjetivo que distingue al sujeto de otros versus su necesidad de pertenecer y adaptarse al medio social y lo instituido. La internalización y la externalización; ligado al proceso de aprehender la realidad en orden de deconstruirla supone cortes que luego sean expresados con adecuación y cualidades atractivas; realidad - ficción: entre lo que se conoce y lo que no existe aún pero se imagina y desea; repetición - novedad la condición de familiaridad y referencia versus un excedente de novedad como factor de contraste y 
de creación de nuevas posibilidades; continuidad - discontinuidad sugiere la tensión entre la subordinación dialéctica y una propuesta de experiencias que transforman la realidad o entre lo intencional - incidental lo intencional como esos espacios en blanco que intencionalmente se insinúan para ser llenados con la imaginación y sensibilidad del otro y la incidental como un espacio de desviación, 'horizonte de posibilidades'(Jauss, 1967) o 'distancia estética' como desfase entre lo que el creador ofrece a la experiencia y lo experimentado por su receptor.

Luego con la indeterminabilidad, se constituye una cualidad estética y no una falta en la estructura conceptual ni figurativa; alude a una intención de mensaje metafórico, simbólico evocativo y no de representación rígida que estanca la creación plástica de la apariencia. Entre unidad - detalle una oposición que en balance faculta el recorrido libre e ininterrumpido del ojo de una totalidad armónica y un descubrimiento fascinante en el detalle que además ofrece al diseñador, la oportunidad de un carácter único a su expresión. Y entre lo bello - feo la persona conoce el amor y el odio, el agrado y la indiferencia, la admiración y el desprecio, la existencia humana se mueve dentro de estas sensaciones polares y entre ellas se percibe la realidad. El dominio de lo bello va desde lo atractivo hasta lo sublime pasando por lo feo siendo este la búsqueda de perfección y del punto más elevado de los sentimientos la conexión con el Espíritu (Krause, 1995).

Consideramos además que, en el manejo de estas dicotomías los contenidos de la forma alcanzan un plano extracomunicativo más multidimensional que la manifestación de cualidades en una materia organizada. Lo que hace al individuo es su interior, su experiencia singular: su subjetividad, lo que está fuera de su entorno. La forma de conectarlos es la significación que se torna afectiva y ahí la fuerza expresiva de lo metafórico, el valor simbólico de la imagen mueve de lo consciente a lo inconsciente, lo que puede aparecer arbitrario a algo con lo que los sujetos se identifican.

El diseñador trabaja por una articulación permanente y dinámica que va del todo a lo particular y viceversa; no hay un orden lineal, tampoco determinaciones impuestas porque su acto de co-creación se da con la alteridad (Folkmann, 2013; Zátonyi, 2002; Sudjic; 2009).

\subsubsection{Forma y Experiencia Estética}

Sujeto y objeto como dicotomía establecen una relación dialógica en la que circula información y como resultado, una respuesta en el individuo. El objeto en tanto mediación para la experiencia estética posee unas cualidades de enunciación que promueven una resonancia emocional, por su parte, el sujeto está dotado de voluntad, memoria, imaginación y sensibilidad para experimentar lo que allí le acontece como apariencia atractiva. La experiencia estética con relación al objeto ha sido más estudiada desde la Psicología perceptual para comprender las respuestas de los sujetos a las apariencias, los diseñadores requieren este complemento de perspectiva positivista al componente subjetivo que se ha venido describiendo:

Crilly, Moultrie y Clarkson (2004), hablan de una interacción estético - semántica en la que las personas otorgan a la apariencia formal del objeto una valoración simbólica que no es neutra porque las personas ponen en juego su memoria, intelecto y plano afectivo. Sin embargo, encuentran que la adecuación y coherencia del mensaje expresado, en tanto 
se corresponde a la categoría funcional del objeto (algo asimilado y que construye expectativas preconcepciones de figuración) y la representación de contenidos simbólicos que conectan valores sociales, más asociados al imaginario de estatus social - marca y unos patrones de la cultura material.

Hekkert (2006), argumentó desde el marco teórico de la Psicología evolutiva, que la experiencia con el producto difiere de la clásica noción de experiencia estética del objeto de arte, de contemplación desinteresada, (especialmente las visuales), argumentando que, la finalidad del objeto y los significados atribuidos a ellos, (los dados por el diseño, y los agregados por interacciones prácticas del sujeto con el objeto), complejizan la percepción. Entonces caracterizada desde la percepción, la experiencia estética está atravesada por tres categorías diferentes que actúan como un conjunto inseparable en la percepción humana: 1. Unidad de placer sensual (algunos principios del gusto son uniformes y no por ello, las reacciones ante ellos), 2. la interpretación significativa (el sujeto acude a memoria, interpretación y asociaciones de experiencias significativas previas) y 3. la implicación emocional (supone la evaluación de un evento en términos positivos o no, para dar lugar a sentimientos de placer o displacer).

Desde la noción de adaptación desarrollado desde la perspectiva biológica como condición humana en que el sistema visual es el principal recurso para la asimilación de patrones organizacionales de información, funciones y apariencias soportan su supervivencia en el entorno, Hekkert vincula este principio a la intencionalidad estética para potenciar el estímulo visual mediante el uso de las catalogaciones de tipologías y detalles de preferencia por parte de los diseñadores. Además, en sus trabajos caracterizó pares polares en las respuestas emocionales: agrado - desagrado, deseo - rechazo, interés - apatía y en las propiedades de la apariencia como el contraste - unidad, la novedad - iconicidad que en tanto balance favorecen juicios de apreciación positiva.

Desde el enfoque pragmático, se ha relevado la conexión con el contexto para la experiencia humana, como fenómeno social el gusto es una variable clave del diseño de la estética del objeto para entenderla como condición móvil e influenciable en la apreciación de las personas y de oportunidad de novedad y contraste.

\subsubsection{Gusto}

Para Kant, la experiencia estética es el libre juego de entendimiento e imaginación donde el juicio del gusto se traduce en un placer o desagrado y por ello, está en el plano subjetivo. El gusto reúne un orden compositivo asimilado en el que yacen esquemas de orden filogenético y ontogenético haciendo que la persona contemple con una predisposición a la adecuación de esa apariencia que se le presenta para luego, encontrarla como armónica o como una ruptura que le lleva a la repulsión.

Para comprender la formación del gusto, Pierre Bourdieu (2010) desde su trabajo en la Sociología antropológica, lo aborda como un fenómeno temporal de acuerdo y "una función de signo social” (p. 68). Allí la práctica estética es una forma de distinción social; es decir que la preferencia de una determinada composición está influenciada por su valor simbólico con relación a la proyección de posición y/o pertenencia de un individuo a un determinado grupo social; sí bien es un aval colectivo y temporal de un determinado 
género, éste es visto por Bourdieu en su naturaleza dialéctica como mensaje que circula y que va configurando lo que él llama campos de capital simbólico.

Entonces el gusto se forma colectiva e individualmente y no necesariamente de manera autónoma, el diseño en sus diferentes expresiones lo modela en tanto más pulsos emite y con los cuales el sujeto se siente representado en la apariencia del objeto y experimenta goce en el aparecer del objeto. Como se mencionó antes, el individuo requiere una adherencia y reconocimiento en el mundo objetivo para constituir y afianzar su identidad. El gusto vinculado al estilo y siendo este el modo de hablar y escribir (en un sentido lingüístico en la retórica) ambos van deslizándose hacia un sistema de los elementos formales de la creación artística que actúa según conceptos formales y coincidentes o parecidos para dar cohesión y refieren a una constancia y a una pertenencia. También a un conjunto de cualidades con que otros le identifican y experimentan agrado. Por último y en el sentido kantiano: el gusto, una representación: "no como pensamiento sino como sentimiento interno" (Aramayo y Mas, 2016, p. 227). Con el juicio del gusto la atención se pone en la expresión y o ausencia de belleza.

\subsubsection{Belleza}

El término belleza es uno de las más ambiguos en su definición con una casi imposibilidad de acuerdo; acude al juicio estético, el cual es visto como un acto de interpretación y construcción de sentido (desde la interioridad del yo), del objeto con su apariencia atrayente y que con sus atributos físicos evoca representaciones reguladas por códigos intencionales; la belleza se convierte en una ficción, una representación mental cargada de subjetividades particulares que exceden la materialidad armónica configurada originalmente y una expresión de leyes universales.

Adoptaremos una noción que procura conciliar tanto propiedades como la condición subjetiva de su valoración: un conjunto de cualidades que aparecen al sujeto para satisfacer su sensibilidad y entendimiento por la adecuación de sus representaciones.

Uno de los tópicos centrales en la doctrina estética y uno de los más problemáticos es el relativo al término belleza. $\mathrm{Al}$ recorrer los diferentes autores se encuentran tres posiciones:

1. Objetivista, liderada por Platón quien le asocia con un tipo de propiedad que cualquier objeto puede poseer y produce placer a su receptor, pasa por lo intrínseco y lo externo de la forma; por algo creado y recreado, por una suerte de normas para su composición; luego la Psicología perceptual desde la Gestalt determina sus leyes de composición como proporción, balance, simetría, armonía y otras relacionadas con mayor detalle.

2. Subjetivista donde "la belleza está en quien la percibe" es una valoración y representación que el sujeto se hace con la apariencia y su bagaje, disposición y contexto socio cultural predominan sobre sus leyes. El "buen gusto" que es relativo y no se somete a discusión de validez.

3. Interaccionista: faculta la relación: sujeto - objeto como una circulación de información que es interpretada; un mensaje dotado de indeterminabilidad así estructurado intencionalmente. 
4. La valoración de la belleza pasa por la confrontación de dicotomías como: valor intrínseco - extrínseco; sentimiento - discernimiento; lo presentado - lo representado; realidad - ficción; particular - universal.

Un abordaje vinculable a expresiones del diseño es el de Popper (1970), uno de los primeros estetas que aborda la belleza indicando que esta posee tres grados de intensidad: 1 . evocativa 2. vívida 3. profunda. Establece que la belleza se asocia a la armónica organización con novedad que procura la intuición pura.

En tanto organización, la belleza puede ser intrínseca si refiere a los fundamentos de simetría, balance, patrones que captan el interés natural de las personas. Es extrínseca en tanto el esqueleto estructural del trabajo que encarna o concreta la expresión formal, posee rasgos de interés social como gusto, estilo, moda y novedad. Como belleza intrínseca - extrínseca posee elementos desde patrones y aportes de variedad y novedad que el creador imprime. Y sí la belleza se asocia con el objeto estético, entonces se trata de aquella composición que posee un atractivo sensual (para los sentidos y la sensibilidad), una codificación intencional de significado estético que es vinculada a una condición fenomenológica, una relación dialógica entre: objeto - sujeto que posee el interés y la capacidad de captar de manera sensible más que con su entendimiento.

También posee tres niveles de variación: 1. Contraste (con relación a tendencias); 2. Gradación e historia (concepto de composición y nivel de disrupción); 3. Variación (con respecto a la unidad en sí, juego de contrastes que captan la atención).

Aplicados estos fundamentos al objeto, este cuenta una historia en su unidad total, proyecta su fuerza expresiva e intención de distinción a través de sus elementos compositivos y detalles contrastantes que captan la atención, pero no disonantes para el conjunto. La organización de esos recursos con el aporte de variaciones y novedades es lo que lleva a la percepción de belleza. Lo que se encuentra bello o feo se mediatiza por los sentidos, que poco a poco se torna información en la que la sensación y la intuición conllevan una representación interna del objeto que se presenta bello en su apariencia de unidad en la variedad, multiplicidad, orden. "es posible que haya precedido la actividad intelectiva, conceptual, así como puede seguir comprobando y comparando, pero lo bello es independiente de toda actividad del entendimiento" (Lemcke, 1945, p. 36).

A la luz de Krause (1983) la belleza se puede determinar objetivamente desde:

1. Categoría fundamental de la belleza es la unidad, como homogeneidad y continuidad. Entendida como unicidad de las partes que la integran entra a constituir una esencia formal con identidad de una categoría reconocible ente la multiplicidad de objetos a los que corresponde (categoría funcional en el caso del objeto) y una esencia única.

2. Categoría de sustantividad la cual se describe como el paquete de atributos que configura y define la apariencia del objeto, se presenta como una propiedad que se basta a sí misma (autorreferencia para nuestro caso de estudio). En el binomio belleza - utilidad, este principio plantea la apreciación de la cualidad estética por sí misma sin juicios ni comparativas.

3. Categoría de todeidad (Ganzheit) lo bello es un todo. Su conjunto constituye la unidad finita; hay límite magnitud, fuerza de atracción y medida de profusión con relación 
a otros. La creación tiene intencionalidad de distinción. Sin embargo, la percepción de desproporción por asociación a similares puede producir rechazo.

4. Categoría de perceptibilidad conformada por la sustantividad y la todeidad de lo bello, es decir la unidad contenida en la medida en el conjunto de sus atributos y en todo caso expuesta al ojo particular del observador, su perceptibilidad pasará del sentido al sentimiento.

5. Categoría de belleza llena, es decir, tiene esencia y contenido desde una perspectiva multidimensional dado que posee: cualidad y género, diversidad, variedad interior, oposición, cantidad y número. Un conjunto de elementos organizados bajo una estructura interactuando incluso, desde su oposición para lograr balance.

6. Categoría de pluralidad la esencia de la belleza se contiene en cualidad y en forma, aquella que contiene: diversidad o variedad en su composición que puede en tanto se capta como unidad armónica posee una esencia de fusión.

\section{CAPÍTULO 2: PENSAMIENTO ESTÉTICO}

\section{Pensamiento Estético}

Con la pregunta ¿Qué caracteriza la formación del pensamiento estético de los diseñadores de la praxis de los Concept cars? y bajo la hipótesis de que formación del pensamiento estético en la praxis de los diseñadores de la General Motors se caracteriza por una construcción relacional con el contexto, las ideas institucionales y fundamentos de composición formal para concebir el carácter estético de los Concept cars.

Este capítulo analiza en la multidimensionalidad de factores, circunstancias, contextos y objetos la formación del pensamiento estético en la praxis General Motors de los Concept cars para caracterizar la estructura de formación del pensamiento estético como conjunto de concepciones que guía el actuar proyectual para estructurar la apariencia del Concept car como objeto estético.

Por tratarse de una operación del actuar proyectual el esquematismo ejecutado para la formación del pensamiento será detallado en el siguiente capítulo y descritos en éste, las concepciones de allí derivadas.

\subsection{Interpretación de Pensamiento}

Se definirán algunos términos de base que precisan ser reflexionados para realizar las inferencias que, por su significancia, aparición y vínculo con la reflexión de la estética del diseño formal del caso, soporten la validez de esta caracterización:

¿Qué es un pensamiento? Una construcción mental en la que se reúnen ideas, conceptos de la realidad y otros elaborados desde procesos intelectuales y de abstracciones de la imaginación. El pensamiento está asociado al conjunto de concepciones propias de un 
individuo o de una colectividad, que guía su actuar. Acorde a Gastón Breyer (2007) “(...) el pensamiento como contenido sustantivo del pensar, y también como el acto, el verbo, el proceso, la operación mental. Contenido y acto fundan al humano" (p. 84).

Con su planteo Husserl (2007) remarca la intencionalidad del pensar y le otorga sentido al acto humano: "El pensamiento es un acto intencional que apunta a un objeto" (p. 85). Por esto y desde la perspectiva fenomenológica, se consideran las condiciones de la experiencia y se indaga por los fenómenos que se manifiestan en el ámbito de formación del pensamiento, posicionando a éste como propone Husserl como un conjunto de representaciones de lo aprendido, una concepción temporal, que dotan de conciencia y capacidad reflexiva a los individuos para la toma de decisiones y para el actuar sistemático e intencional. Reintroducimos los términos griegos de noesis y noema; el primero como el acto de pensar al objeto, puede ser explorado como modo de pensar en un espacio de creación del sujeto donde abstrae elementos de la realidad, los sintetiza y reflexiona para la producción imaginativa. El segundo, noema, refiere al contenido de información producida, al objeto como salida del acto de pensar concretado como proposición lingüística, figura y otras propiedades formales.

Como experiencia fenoménica, la formación del pensamiento estético GM en la praxis de los diseñadores Concept cars, es un acto de pensar el objeto: estética del automóvil. En tanto contenido, ese objeto se construye en el pensamiento; una construcción inteligible que se convierte en expresión perceptible: estructura narrativa y de figuración para la estética del objeto.

Con el propósito de comprender la multidimensionalidad que conforma el pensamiento estético en el fenómeno Concept cars, se observará desde diferentes orientaciones filosóficas. Con Castoriadis se guía una mirada ontológica del diseñador en su potencialidad transformadora y de promover la constitución de lo nuevo, poniendo en juego parte del transcurrir de su historia individual mientras hace parte de una colectiva se conecta con el contexto a través del par imaginario - simbolismo. El primero como el sentido que circula y el simbolismo como su expresión, que faculta la comprensión de la realidad. Como representación, imaginario - simbolismo no es de libre constitución, no ejerce pleno control, aunque condiciona los actos sociales y la apreciación individual del entorno, es susceptible de transformarse.

Con Bourdieu (2013) se aborda la sociedad como un grupo de personas que viven en un mismo territorio físico y comparten un sentido de identidad, ideología, prácticas y creencias donde se marca el Habitus "sistema de disposiciones duraderas y transferibles, estructuras estructuradas predispuestas a funcionar como estructuras estructurantes, es decir como principios organizadores de prácticas y de representaciones que pueden estar objetivamente adaptadas a su fin sin suponer la búsqueda consciente de fines ni el dominio expreso de las operaciones necesarias para alcanzarlos, objetivamente "regladas" y "regulares sin ser en nada el producto de la obediencia a las reglas y, siendo todo esto, colectivamente orquestadas sin ser el producto de la acción organizada por un director de orquesta" (p. 14).

Se considera a esta visión fundamental para organizar el conocimiento y la elaboración de estos principios y modos de exteriorización del sentido social, para generar la posibilidad en el diseñador de ir más allá de la homogenización; y para captar el deseo de expresión 
individual como el de estatus social a través de las prácticas estéticas o el interés por la novedad.

Por otra parte, extraigo de Simondon (2016) la idea de que el pensamiento simboliza un paradigma en el sentido de tratarse de una unidad con cualidades de formación localizadas espacio temporalmente, una correlación entre el dominio del sujeto y del dominio del objeto, ambos conforman una estructura polar; sus tensiones se complementan y dan balance a la estructura con la que se intercambian significaciones y símbolos como estereotipos sociales o formas de expresión de la cultura material.

Condiciones para que un pensamiento reflexivo puede considerarse como concreto:

1. De animación y contenido susceptible de análisis. El sujeto: un diseñador inmerso en un contexto socio histórico, su objeto la información que capta, interpreta y transforma en otra productora de un nuevo sentido para la estética del diseño del automóvil. "El individuo y su accionar no pueden ser considerados como una nada o un absoluto sino como término de relación real" (Simondon, 2016, p. 27).

2. La validez para esa reflexión, la cual es soportada en el mantenimiento de una integridad en la relación del marco conceptual y la que reside en el contexto de investigación como la dinámica viviente del episodio histórico, con sus circunstancias y entorno ideológico particulares.

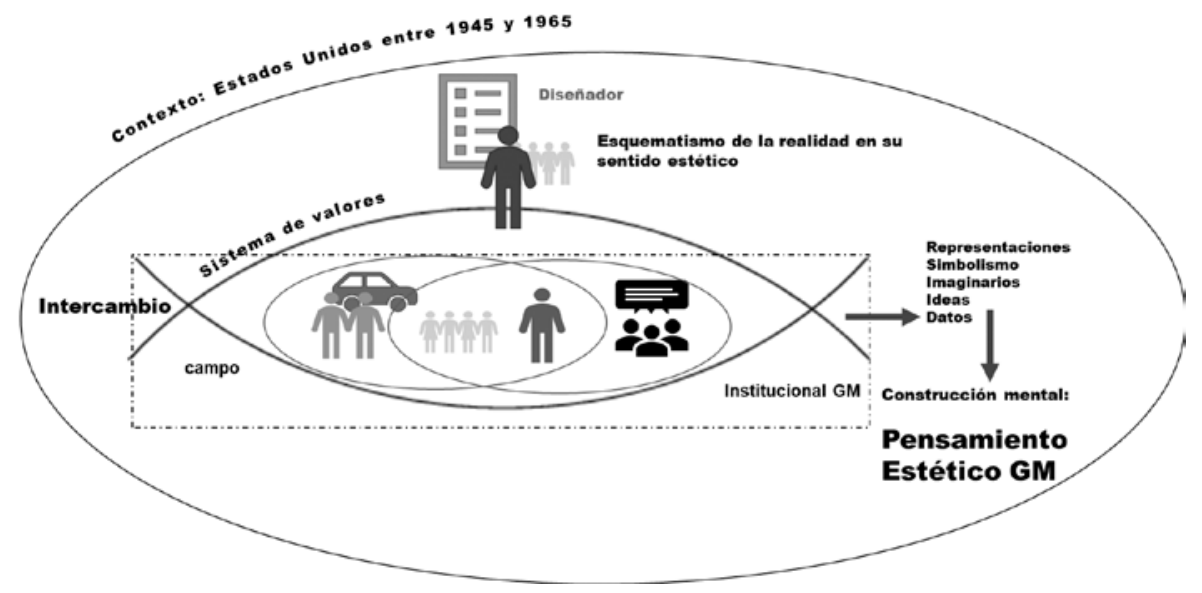

Esquema 1. Esquema de Componentes de Formación del Pensamiento Estético del Diseño. Fuente: elaboración propia. 


\subsection{Campo de Formación}

Para responder a la pregunta ¿cuáles son los contenidos más significativos del campo para la formación del pensamiento estético GM, Estados Unidos entre 1945 y 1965?, se toma la noción de campo de Bourdieu (2010) como sistema de posiciones y sus relaciones objetivas, con una estructura y capital (simbólico, cultural, social) acumulado que orienta las estrategias de los actores, y que asume también una existencia temporal de posiciones y sus relaciones objetivas en las que los agentes establecen una dialéctica de adhesión, conservación o transformación.

La Segunda posguerra mundial en la sociedad estadounidense caracterizada por la libertad, oportunidad de progreso, el gusto por la abundancia y exuberancia, el artificio y entretenimiento, se vinculan a la expresión de Sueño Americano acuñada en 1931 por James Truslow Adams, como una "vida [hecha] mejor y más rica y plena para todos, con oportunidad para cada uno de acuerdo con la capacidad o el logro, independientemente de la clase social o las circunstancias de nacimiento"18.

El filósofo francés Louis Althusser (1971) en su observación sobre cómo se constituye el ser institucional y su acción en los individuos argumenta que un individuo se define por su función social, como sujeto único, un individuo instituido que tiene ideas que son acciones materiales insertadas en prácticas materiales gobernadas por rituales materiales que son definidos por el aparato ideológico material del cual derivan las ideas para el sujeto. Interpretando la perspectiva de Althusser, el campo del individuo es el aparato ideológico, el espacio de prácticas, rituales y un entorno material; concreto, dinámico y hegemónico.

La tensión que emerge allí es la de autonomía - adecuación pues, el sujeto dotado de imaginación interpreta el intercambio significativo con el aparato ideológico, las imágenes y circunstancias. Luego, procurará su transformación consciente e intencional en otra más deseable. $\mathrm{Al}$ respecto, la capacidad reflexiva del individuo se puede definir como el proceso de aprendizaje acerca de quiénes somos, cómo creamos nuestra identidad y cómo el individuo sortea subjetiva y objetivamente su intercambio imaginario con el contexto (Giddens, 1991); lleva al diseñador a plantearse una intersección entre su propia experiencia y la información externa, es decir la creación como novedad y no sólo de representación de la realidad.

Castoriadis ya había mencionado esa habilidad imaginaria y transformadora del diseñador en tanto creador de un contenido que se hace imagen apreciable; por su parte, Adorno (1980) [1970] discute que el arte está inevitablemente ligado a la realidad y representa valores sociales o de estatus social (estatus quo); sin embargo, su creador debiera resistir ese ser, absorberlo y rehacerlo. Su aproximación de fantasía en el acto creativo y de expresión del arte, yace en un modo de resistencia a la representación de la sociedad y más bien una "aparición" en tanto manifestación de algo que existe, existió y está por existir. La aparición es para el autor, una realidad inaprensible en la que se presenta (aparece) algo que no existe; reconociendo la belleza en la indeterminación de las cosas, su capacidad de sorprender. Una clara invitación a la novedad desde el acto estético del diseño.

Nietzsche [1872] (2010), sostiene que el origen de placer que ofrece una expresión estética no está en su determinabilidad, como potencial de dominación o reflejo de lo normado 
institucionalmente; reside en su indeterminabilidad, el mensaje de imposibilidad de dominar lo real. Se trata de crear un orden de ideas y orden sensible que movilice la fantasía del sujeto y le faculte el escape imaginario a su libre contemplación estética. Así el pensamiento estético en su carácter performativo se constituye un puente de conexión de las personas con su mundo sensible; un juego de intercambio de doble vía y no lo que norma o instituye, procurando controlar todos los contenidos o sus interpretaciones.

El diseñador, como sujeto inmerso en ese aparato, internaliza un set de ideas institucionales de índole hegemónico, representaciones, habitus, patrones que condicionan su pensar $\mathrm{y}$ actuar. Con su habilidad transformadora los retorna, a la práctica material en expresiones performativas con adecuación a los rituales instituidos y compromiso de fantasía y novedad.

\subsubsection{Campo y Diseño Estético: Influencia Recíproca}

Con relación a la búsqueda de transformación en el espacio temporal de transición, Susan Langer (1996) en la publicación del Simposio de Diseño sobre ¿Quién diseña a Estados Unidos? recalca el papel de los diseñadores en el modelado de una "nueva visión de la realidad que exprese una nueva forma de sentir hacia el mundo (...) alguna forma del mundo hacia la cual nos dirigimos" (p. 15). Su propuesta se orienta a la necesidad de comprensión de las leyes del entorno y su relación con las metas del diseño para producir formas plásticas, con belleza estética, que creen nuevos entornos visuales y de significación para las personas. Con relación a Estados Unidos de los 60s, buscar un balance frente a las exigencias de artificio con líneas orgánicas y naturales, por ejemplo. Su argumento es que el entorno afecta a sus habitantes y al diseño de manera recíproca. De esa influencia cruzada, se nutre la producción plástica del diseño, que luego consiste en la expresión de ideas sobre la realidad subjetiva y que pueda ser sentida, referida a sentimiento de emoción y no sólo a una estimulación sensorial.

Langer afirma que: "la forma es estructura, es articulación, un todo que resulta de la relación de factores mutuamente dependientes. Es el modo en que se reúne el conjunto, o el todo" (op cit. p. 24). Así, la estructura interna de la forma es particular y se corresponde a los imaginarios del entorno sin que ello limite una suerte de indeterminabilidad para estimular la imaginación.

La forma plástica del objeto estimula memorias y fantasías en el individuo que hacen ver la experiencia estética como un modo de resonancia emocional cuando la expresión visible de lo invisible pueda ser captada. Producirla implica proyectar un pulso de ficción y del sentido de realidad a través de las imágenes. Una circulación de información entre sujeto y objeto con juego de subjetividad - objetividad, determinabilidad - indeterminabilidad que llegue al sentimiento, al intelecto, la percepción y la imaginación. La calidad estética de esa forma se refleja en la presentación objetiva del sentimiento a la percepción directa del espectador y de los significantes que soportan su identidad.

Las actitudes sociales y los objetos como portadores de contenidos significantes de la cultura soportan la construcción discursiva del diseño y la construcción semántica del sentido estético. Los diseñadores deben comprender que una nueva época cultural es siempre un nuevo sentir hacia el mundo, mientras éste se forma. El diseño contribuye en la mo- 
dificación de la escena y en la representación de los símbolos que circulan en la sociedad. Acudir a referentes y tomar de ellos rasgos para ser incorporados en nuevas expresiones, facilita un vínculo con la familiaridad y una conexión emocional con las nuevas propuestas. "No es necesario despejar los viejos símbolos para poder reemplazarlos por los nuevos; la vitalidad de los nuevos, una vez que se ha manifestado en una forma expresiva verdadera, ha de suplantar a los viejos" (Langer, 1966, p. 38).

Sin embargo, lograr este balance genera tensiones y contradicciones para quien crea bajo ideales tradicionales y la incertidumbre de lo que se construye. Entonces, la responsabilidad del diseño en la creación de la escena con su contribución plástica en el entorno, Langer la puntualiza diciendo: "Así como el lenguaje es la matriz del pensamiento, el arte lo es del sentimiento" (1966, p. 39).

\subsubsection{Simbolismo e Imaginarios del Campo}

En las décadas de los años 50s y 60s en el campo de estudio, se suceden una serie de eventos y se produce una información que construye un set particular de concepciones que guían el pensar y el actuar individual y colectivo. Para los 50s un período de Segunda Posguerra Mundial mayor apertura a la transformación y al modo de apreciar la calidad de vida, abundancia, expansión, libertad aparente, se vuelcan a la vida material, simbolismo - imaginarios, novedad y fantasía influencian al colectivo. El deseo por el auto de lujo (Personal luxury car) y un sentimiento de sentirse único en la masa, invade a la clase media, el poder ruge en los motores. En los 60s con la consolidación de la red federal vial con 65,983 km de costa a costa, el escape, la libertad de viaje y de modos de relacionarse socialmente instala en los jóvenes una ideología de escape más que de arraigo, de disfrute del entorno con extraños, los habitantes urbanos están más a la espera del modelo anual, estimulando la obsolescencia programada, la que perciben como renovación constante de su cultura material; práctica y rituales estadounidenses.

El sociólogo francés Bourdieu (2010) y el filósofo alemán Jürgen Habermas (1981) concuerdan en que hay una relación dinámica entre los individuos y su contexto sociocultural; allí se produce un intercambio significativo, de ideas, imágenes, valores y habitus los cuales, dotan individual y colectivamente a las personas para su aprehensión del entorno. La sociedad y las instituciones constituyen su propia red simbólica y no con plena libertad; ésta se teje arrastrando historia y material de la realidad presente; entendida como un encadenamiento de significantes de las representaciones que circulan a través de las personas, los actos y los objetos materiales, esta red de realidad y fantasía penetra y condiciona a los individuos y a su actuar social.

Según Castoriadis: "La sociedad constituye cada vez su orden simbólico en un sentido, totalmente otro del que el individuo puede hacer. Pero esta constitución no es «libre». Debe también tomar su materia en «lo que ya se encuentra ahí»" (Castoriadis 1999, p. 193). Y añade: "Nada de lo que pertenece propiamente al simbolismo impone indefectiblemente la dominación de un simbolismo autonomizado de las instituciones sobre la vida social; nada, en el simbolismo institucional mismo, excluye su uso lúcido por la sociedad" (Castoriadis, 1999, p. 201). 
Las personas hacen uso inmediato de los simbolismos que circulan y por ello pueden dejarse dominar por ellos o resistirse mediante una posición reflexiva desde sus propios intereses. Por ejemplo: el título de propiedad del automóvil constituye un símbolo de derecho sobre su tenencia y un símbolo de estatus social o de logro por el trabajo, quizás un buen manejo de la economía personal. O una forma de práctica estética que simboliza una identidad con un grupo social con preferencias y capacidad adquisitiva particulares. Un componente fundamental del símbolo es el imaginario. Se lo puede definir como: algo inventado ya se trate de un invento absoluto (...) o de un deslizamiento, desplazamiento de sentido, en el que unos símbolos ya disponibles son investidos con otras significaciones que las suyas 'normales' o 'canónicas'.

El imaginario usa lo simbólico para expresarse, para manifestarse ya sea como representaciones directas o de otra cosa, pero es por la imaginación que un sentido puede ser desplazado a otro. Anticipar algo que no existe requiere de imágenes que evoquen símbolos reconocibles para su conexión, así que ambos se complementan. El símbolo es la expresión del imaginario, a través de el en sus representaciones, los individuos ponen en juego comprensión y fantasía.

El símbolo supone como significante de representación real, contenidos de significado reconocible en el contexto; su amarre a raíces sociohistóricas también posee rasgos de imaginario (s) que conectan con la capacidad imaginativa de las personas para captar algo que no siempre está presente. Para soportar su actividad creativa, que, por ahora, se enmarca en evocar en una imagen la representación de una cosa, el diseñador debiera procurar un conocimiento de los contenidos del contexto imaginario-simbólico y así producir nuevos deslizamientos de concepto que pudiesen ser atractivos en rasgos extra comunicativos que excedan el concepto canónico del automóvil y le potencien como expresión sensible de las aspiraciones sociales.

La General Motors está estrechamente vinculada a los intereses y planes de gobierno, así que está implicada en sus aparatos ideológicos mientras construye los propios. Lo que atañe al equipo GM de diseñadores es una articulación de esos tejidos imaginario-simbólicos de la realidad, con las raíces y apetencias sociales y su propia construcción de sentido. "La psique crea un flujo incesante e incontrolable de representaciones, deseos y afectos/ intenciones" (Castoriadis, 1999, p. 180).

En el marco de la estética del automóvil, el diseñador procura subjetivizar el mundo objetivo de lo instituyente. Para ello debe transitar por una trama multidimensional de ideas, las cuales debe intercambiar y fusionar con otros en un proceso de co-creación. La concepción del carácter de la apariencia del automóvil debe ser concertada con actores institucionales y del colectivo que busca además del aspecto, ciertos rasgos de la identidad de su cultura ${ }^{19}$ y de conexión sociológico-afectiva.

\subsubsection{Imaginario Social: Lo Instituido y lo Instituyente}

Con una postura que releva la esencia cambiante y de poder transformador del individuo, su capacidad reflexiva e imaginativa y no sólo de adhesión y modelamiento por lo normado en el contexto, Castoriadis en su obra La Institución Imaginaria de la Sociedad (1999c) trabaja en el cómo se instituye y transforma la sociedad. Resiste a las ideas absolutas del 
'Ser' como entidad absoluta, o sustancia inalterable, plena, total y estática; por el contrario, reconoce en la habilidad psíquica de la imaginación humana en combinación con teoría y práctica, una habilidad de permanente transformación que opera tanto individual como colectivamente.

$\mathrm{Al}$ acto de imaginación colectiva que ejerce una cierta autonomía (de autos sí mismo; nomos ley es autónomo aquel que se otorga a sí mismo sus propias leyes), lo identificamos como imaginario social instituyente, se distingue de lo instituido porque éste se ha normalizado desde las instituciones. Para el acto creativo más que un ejercicio de mímesis o de representación lo más cercano posible a la realidad, dentro de normas establecidas, supone introducir una propuesta novedosa, disruptiva y hasta radical de cambio. En ese sentido la General Motors adhiere al gobierno representando valores de lo instituido ideológicamente, pero ejerce su autonomía para constituir sus propios imaginarios, imitar referentes y deslizar su sentido con nuevas simbolizaciones.

A la noción de autonomía se la vincula la de imaginación en la que se encuentra como una herramienta para el actuar lúcido, consciente e intencional para la combinación de representaciones existentes y la creación de otras novedosas que como accionar social, generen nuevas realidades. El pensamiento estético como mensaje es una intervención social que procura esa conexión emocional, no sólo por el reconocimiento de lo instalado sino por el movimiento de sus fantasías.

\subsection{Dicotomía: Sujeto - Objeto}

En tanto la intención de la estética del automóvil es la conexión sociológico-afectiva con los sujetos, resulta apropiado abordarla desde el postulado de Husserl (2011) en donde lo experimentado por el sujeto con el objeto está supeditado a la cualidad y materialidad que ofrecen un aspecto y contenido conceptual bajo el cual el individuo dispuesto y habilitado tiene una vivencia. Esa vivencia es una experiencia que comporta percepción de representaciones de la fantasía y la imagen, actos de pensar y sentimientos emergentes en un momento determinado. Sujeto - objeto tienen una disposición de intercambio. Con la esencia intencional del objeto ${ }^{20}$ : un todo con materia y cualidad posee esencia de significado, el diseño de la estética del automóvil como acto intencional, debe resolver el carácter de la cualidad de la materia organizada como concepto y aspecto y del cómo éste es dado para la experiencia del sujeto.

\subsection{Ideología del Campo: Fantasía, Identificación y Goce}

Al conjunto de ideas acogidas por un colectivo humano se le denomina ideología. Ésta es la relación imaginaria entre los individuos y las condiciones reales de su existencia (Althusser, 1971). En ella reconoce una cierta determinación del individuo por lo instituido en su mentalidad y cómo se relaciona luego. El teórico cultural Slavoj Žižek en su obra El sublime objeto de la ideología (1989) asocia la ideología a una discursiva hegemónica que tiene un carácter performativo que recurre a la fantasía, la identificación y el goce. 
Con la fantasía como ilusión generalizada del deseo, constituye un argumento imaginario que soporta la realidad y encubre o disipa cualquier división social o antagonismo; la identificación es un proceso en el que los individuos adhieren al imaginario y se afianza la ideología; el goce que opera en el plano subjetivo facilitará la creencia en la ideología instituida como conjunto de símbolos reconocibles de identidad. La ideología es a la vez una integración simbólica, de carácter imaginario, cuyo límite es la experiencia cotidiana en tanto la modela o es internalizada por las personas a través de su fuerza persuasiva; en su dialéctica cargada de tradición y de transformaciones en su trama de significantes constituye: "cosas que no significan nada, de repente significan algo, pero en un terreno muy diferente" (p. 88). Que puede ser interpretado como una transferencia en el sentido de un significante o concepción creada por otro (individuo, momento, contexto) instalada en otros, posee elementos del pasado y luce como una anticipación al futuro a la que Žižek enmarca en una ilusión/percepción subjetiva de un proceso objetivo que tiene lugar en la llamada realidad, para transformar su escena, aunque sea sólo de manera imaginaria hasta que ya es parte del estado de cosas de la historia personal.

En su estudio Gartman (1994) remarca que, a través de la esteticidad del diseño del automóvil, se procura disipar las fisuras sociales que vino creando el fenómeno fordista y las lógicas de producción aunadas al incentivo del consumo en un ciclo de distracción de condiciones de inequidad para la clase trabajadora estadounidense quien, ya aprecia el mundo material y el orgullo patrio.

En la ideología como aspecto de la mediación humana no existe una creencia común, lo que hay es la creencia en que los demás creen y que produce en los individuos una división entre la realidad social en que se mueven y su propio sueño ideológico. En ese sentido, el poder significante de la ideología ejerce "fantasías de control" (Žižek, 1989 p. 78). Su mirada destaca el potencial semántico de los discursos que circulan y cómo sus significados penetran la sociedad, procurando su adhesión y toma de acción a una "fantasía inconsciente” (p. 61) con sensación de identificación y agrado. En el sentido estético, una fantasía de persuasión que se disfruta a través de las figuras que crea.

La ideología ejerce una influencia en el pensar y actuar individual - colectivo con respecto a la adhesión de figuras ilusorias o de fantasía para su agrado. De esa manera, podemos conectar con la "práctica estética" definida por Bourdieu (2010) como una forma de distinción social que se nutre de las experiencias: social, cultural y económica que estructuran las preferencias del individuo. El hecho estético como un acto dialéctico caracterizado por una conciencia liberadora de sentimientos, impulsadora de imaginación, es mediado por el objeto como expansión de la propia existencia. Una comunicación entre diseñadores y la sociedad que intenta una resonancia emocional.

\subsection{Utopía Estadounidense de la Segunda Posguerra Mundial}

Para 1945, luego del final de la II Guerra Mundial, un aire de nueva mentalidad y de consolidación de la utopía del sueño americano (American Dream Life) libres, convencidos de que "Dios Bendice a América" (God Bless America ${ }^{21}$ ). La democratización de lo diseñado (asequible a la clase trabajadora), favorece el fortalecimiento económico. El deseo de an- 
ticipación del futuro y el gusto por lo material están en pie. Un momento para incentivar la expansión del consumo del automóvil, el renglón más importante de la economía local; este objeto considerado el más significativo de la Modernidad, de la cultura de masificación de la producción, de proyección de estatus social, tiene el contacto más frecuente en la vida cotidiana y cultural de la sociedad estadounidense (Gartman, 1994; Ballard, 1996; Temple, 2015; Silvestre, 2016). Simboliza para el adolescente: punto de partida hacia la libertad, la vida social, el cortejo y la vida amorosa. "La importancia del automóvil deriva de la centralidad del objeto en la transformación de la vida urbana" (Giucci, 2007, p. 16). América es el territorio del pensar pragmático en que la convicción idílica de ideales de justicia, abundancia, rectitud, riqueza, libertad, instituye su sociedad. La convicción de creerse el centro del mundo, de la realización posible de todo lo soñado, le mueve a la materialización inmediata; los estadounidenses lo saben, lo creen y lo realizan. Los 50s el éxtasis del poder, el poder del poder, Jean Baudrillard (1986) en su libro titulado América, con la expresión 'utopía realizada' la define como "la versión original de la modernidad y Europa como la versión doblada y subtitulada” (p. 86).

El lugar donde se convierte en operativo lo ideal, el imaginario que otros cultivan pero que los americanos, concretan. Los americanos han creado su propio imaginario y lo realizan en infraestructura para un estilo de vida materialista. Un entorno de objetos concebidos para embellecer la vida cotidiana e incentivar el placer por la exageración y la abundancia como sinónimo de bienestar. De allí que la utopía adopta una forma discursiva que involucra los imaginarios como concreción de ideas propuestas manteniendo la conexión entre la realidad presente y los eventos pasados para la resignificación de experiencias, y el automóvil, simboliza su utopía.

Su idea de sentirse centro del mundo y suprema potencia, modelo absoluto no es falsa; América se lo cree y finalmente otros acaban creyéndolo y envidiándoles. Esta elevada estima, va a proyectarse a su obra material, al entorno visual, material y social. Lo hiper en el sentido de representación de su grandeza, de valor extraordinario va a ser trasladado a su pensamiento estético: escala y proporción hablan de ello; helados, hamburguesas, casas y autos son más grandes en América. "(...) el surrealismo sólo es extravagancia estética (...) el exceso correspondiente al espíritu y las facultades mentales pasan a las cosas” (Baudrillard 1986, p. 119).

¿Cómo entender la alusión de América como la utopía realizada de Baudrillard? Paul Ricoeur (1977) en su trabajo Ideología y Utopía refiere la utopía como "que se dirige a la realidad; trata de alterar la realidad. La intención de la utopía es seguramente modificar las cosas establecidas" (p. 306); un rol de transformación y resignificación de imaginarios previos, que se apoya en las narrativas que produce y en las acciones que se van concretando en el presente; juega con opuestos de la austeridad a la abundancia; del dolor a la felicidad, de la incertidumbre a todo lo que es posible en América, "una utopía está siempre en proceso de realizarse” (p. 292). Los europeos que poblaron Estados Unidos y que fueron más allá del exilio y de la ruptura geográfica, a la creación de un mundo ideal, a la exteriorización de ideales de la cultura europea que se tornaron imposibles, pueden ser concretados en estilo de vida americano, saben que ahora es tiempo de posguerra, tiempo de materializarlo. El pragmatismo americano persiste en el propósito y en la acción, "sin precedentes de modelos" (Baudrillard, 1986, p. 110). 


\subsection{Pragmatismo: del Pensamiento a la Acción}

Para entender la significancia del pragmatismo como sello americano, debemos remitirnos a John Dewey (2005) quien representa la tradición pragmática. En su perspectiva ha tenido una gran influencia en el pensamiento y la sociedad estadounidense en general. La idea de pensar está estrechamente relacionada con la acción: Hagámoslo (Let's do it!). La acción humana es la fuente de reflexión, que puede desarrollarse en un entendimiento conceptual que constituye el marco para una comprensión confiable del mundo. En su producción, el pragmatismo valora los efectos más que los objetos, la experiencia vivida a través de los significados en las formas. Con formas refiere a modos de hacer, al sentido y no sólo al aspecto de lo que concreta. De esa mirada se obtiene una mentalidad de realización de nuevas posibilidades mientras se constituye la experiencia.

Dewey considera que toda experiencia está constituida por la interacción entre sujeto y objeto entre un yo y su mundo, no es solamente física, no es solamente mental. La experiencia estética es particular y evoluciona en contexto, combina y unifica tanto el deseo como el pensamiento, lo pensante y lo práctico, lo sensible y el significado en ese sentido evoluciona en contexto. El receptor no es un contenedor vacío sino un agente activo. A partir de su mirada, se puede inferir que la estética del objeto es expresión de la creatividad humana vinculada a sus concepciones, a la experiencia cotidiana y a lo presente en la cultura. En tanto composición canónica contempla coherencia, armonía, equilibrio, pero es el sujeto quien la vivifica desde su interior.

¡Hagámoslo! Su convicción del aprendizaje a partir de la experiencia habilita el error como parte del proceso y como una oportunidad de refinamiento en el hecho consumado. Acciones materiales que se insertan en prácticas materiales. Un ejemplo concreto: el Cadillac. Esta marca que, desde su origen, se concibe como auto de lujo, es adquirida por la General Motors en 1909, afectada por la gran depresión, resurge en la Segunda Posguerra con nueva visión del pensamiento estético GM. La serie que se extiende hasta 1965, va a presentar variaciones que son punto focal tanto para la marca como para quienes aman poseer sus automóviles y encontrar rasgos de novedad cada año. Ideas estéticas, hibridación, ética estética para asumir continuidad y discontinuidades, recorte de realidad respecto de arquetipos ya internalizados en la sociedad son aplicados en su práctica.

Para 1947, los diseñadores GM empiezan a consideran que la apariencia del cuerpo del auto debe expresar más que el Streamline ya adoptado por la competencia y presente en sus modelos. Hasta la producción de 1946, la segmentación de zonas desde guardabarros a puerta y portamaletas y trasero son evidentes; a partir de la línea de horizonte (belt line) suele darse el acento de líneas curvas y contrastes entre convexos y superficies planas; todas las marcas juegan la misma fórmula. Sin embargo, para el pensamiento estético en formación, el foco empieza a ser la necesidad de imprimir un carácter único un mensaje distintivo para cada modelo en función de los diferentes perfiles de individuos y de propósitos de movilidad psíquica, física y de imagen personal en el contexto social y no sólo Geográfico. Una trama de precedentes con ideas disruptivas conectadas a los nuevos imaginarios y simbolismos de la ideología institucional.

En la versión 1951 este Cadillac de Ville con un cuerpo más alargado y de líneas sinuosas, bocel cromado que viaja por debajo de la línea de horizonte desde el guardabarros delan- 
tero a la puerta y banda blanca en las ruedas, se busca enfatizar la proximidad del cuerpo al suelo y con ello dos sensaciones: velocidad y estabilidad.

Para la versión de 1956 'más largo que ancho', unidad armónica y mayor continuidad en la línea, con juego en los detalles: contraste de color, el cromado cobra notoriedad con la proporción de ornamentos: boceles en cola, punteras delanteras y traseras que evocan aeronave y cohetes, se trata de un cuerpo más integrado. Según los diseñadores de GM, se trata de que el ojo recorra la línea sin interrupciones y que la atención sea captada por los detalles de mensaje metafórico en su aeroestética. Para Earl, se trata más que de composición figurativa, se trata de otorgar un alma a la forma, dotarla de una narrativa que sea contada a través de la apariencia atractiva del auto y de un aparecer que promueva la emoción.

Para la versión 1959 su valor simbólico es la fuerza expresiva de su imagen, y su punto focal está en la exageración de la cola en los detalles de las luces, la representación de cohetes y sinuosidades en su superficie con contraste en el manejo de angulaciones (cola, techo plegadizo, ventanas). Ahora la línea viaja desde las luces traseras hacia adelante, acentuando la línea oblonga y dinámica de su serie.

\subsection{Diseño el Gran Diferenciador}

Dentro de la época se reconoce la presencia de quienes representaban el funcionalismo como modelo de pensamiento formal, del surgimiento del racionalismo funcionalista en Europa con centro en la Hochshule fur Gelstaltum de la ciudad de Ulm y con quienes conviven en Estados Unidos como producto de la diáspora de la Bauhaus. Si bien se menciona que en el sector automotriz se adhiere al punto de vista ideológico, la Deitscher Werkbund apostó por la fusión entre el arte y la máquina promoviendo la industrialización con discusiones como la que versa entre belleza y función o las posibilidades de materialización sin detrimento de la naturaleza artística, esta visión fue más orientada al objeto de la vida cotidiana. Durante el periodo de estudio, la participación de artistas, modelistas, empíricos y diseñadores formados en escuelas como Pratt Institute va a enriquecer la construcción progresiva del artefacto industrial con un sello propio estadounidense que se distinga del europeo. Para los ejecutivos de la General Motors, seguir lo que denominan viejas líneas de pensamiento es jugar sobre seguro cuando observan que a ese punto modelos de marcas como Chrysler, Ford y de la General Motors tienen apariencias similares con dominancia de líneas orgánicas pero con ausencia de un carácter propio, distintivo que pueda conectar con los diferentes grupos de consumo que están promoviéndose. También guiados por el pragmatismo cuyo enfoque se orienta a la finalidad, a la inmersión del individuo en el contexto para que las ideas que surgen de su intercambio se concreten con la experiencia, pero es la narrativa de una realidad idealizada lo que va a pautar su apuesta de ficción, por lo que, la expresión simbólica va a hacer un recurso clave de este carácter estético.

Algunos antecedentes clave de los Concept cars. En julio de 1926, Walter Sloan presidente de la GM había planteado que los automóviles se parecen cada vez más y que el diseño es el factor diferenciador entre marcas. Promovió un proyecto experimental que fuese más allá del paradigma formal tipo caja comandado por la ingeniería y las líneas aerodinámicas 
de los 40's con una suerte de monotonía compositiva. Su postura fue la combinación de esfuerzos entre diseño, negocios y tecnología para la innovación; para mostrar el camino del futuro de los vehículos de una forma excitante, tal que las personas lo vean, lo sientan y quieran avanzar juntos. Para ello se requiere una manera diferente de abordar la estética del automóvil, porque la tecnología experimental no es el medio para producir emoción en los potenciales compradores; una que enlace el sueño americano: una nueva clase-móvil de sociedad estadounidense que aprecia nuevas formas de belleza funcional, una fuerza expresiva, evocadora a partes funcionales y al cuerpo del automóvil, esto implicaría poner mayor esfuerzo en el detalle y su vivacidad.

La GM emprende un proyecto ambicioso, expandir el departamento de Arte y Color (Art and Color), equivalente a la actual área de diseño acentúa en su nombre dos derroteros: concepto de la expresión y su manifestación en la superficie material del automóvil. El color va a ser un recurso de vivacidad y diferenciación. Ahora los diseñadores lideran una interacción multidisciplinar con la ingeniería, el marketing y la gerencia de negocios.

Su líder en jefe: Harley Earl, el talentoso diseñador del LaSalle (1927), elegido el auto oficial del circuito de Indianápolis de 1927, ha ido formando su pensamiento estético con influencia de Hollywood. Su padre posee un negocio de personalización de los automóviles de los artistas de esta industria de ficción y entretenimiento que impacta la psique de la gente y atrae multitudes. Estas estrellas buscan una notoriedad social con un sello de autenticidad como sujetos únicos y provocadores y el automóvil es su mejor medio de proyección, además de un poder de exclusividad al transformar los modelos comerciales. Así que la fantasía que excede lo normado, un carácter simbólico distintivo con fuerza expresiva en la que la extravagancia se justifica para la notoriedad, son algunas de las ideas que forman su pensamiento estético.

A partir de esa experiencia Earl siempre resaltó que las ideas de sorpresa y novedad en la estética vienen de las personas y es el diseñador quien les da carácter y manifestación material. A lo que añade: testear diferentes composiciones para captar la emoción de las personas, cuanto más intensa, y coincidente en el público, más confianza para hacerlas comerciales $^{22}$. Una fórmula que no funciona cuando la novedad es disruptiva: la respuesta ante la cola exagerada del Cadillac de Ville 1959 tomó alrededor de dos años, antes de volverse un éxito comercial.

En 1942, la industria automotriz estadounidense dejó de producir máquinas de sueño aerodinámicas y dedicó sus recursos a la producción en masa de máquinas de guerra que conservaron la línea conocida como Streamline. Para finales de 1945, cuando termina la Segunda Guerra Mundial, el sector del automóvil con la mayor ocupación laboral (más de 5 millones de trabajadores), enfrenta un nuevo desafío: la estimulación de las personas para el consumo y el afianzamiento de la ideología anticomunista.

Una nueva estética es necesaria, una que conecte con el imaginario social instituido de libertad y democracia, paz y progreso, a lo que suman los ideales de abundancia y poderío militar. Estos valores son abstractos para los individuos y la vía para ser percibidos como bienestar es incentivar el deseo por el estilo de vida americana que disfruta de la posesión material (Gartman, 1994).

El impulso de la masificación del automóvil, el objeto de mayor deseo aspiracional de la clase media estadounidense, se combina con el proyecto GM, total respaldo de la presi- 
dencia GM y un presupuesto millonario, se empodera a los estilistas para producir una propuesta estética sin precedentes: los Concept cars o Dream cars, la concreción de la anticipación del futuro de la movilidad física y psíquica en la que el automóvil adquiere un carácter de autenticidad, un alto valor expresivo en su forma y un mensaje de carga metafórica de valores de poder, libertad, sensualidad, distinción.

Earl asiste a Stanford University y tiene una fuerte inclinación por los negocios; el diseño estético es interpretado por Él y Sloan como una punta de lanza para la conexión con las personas. Earl afirma que "el progreso del arte del Diseño hasta hoy, es considerado como uno de los factores más importantes de comercialización del automóvil” (1942).

Earl quien entiende el diseño y los negocios como una instancia de creación de empatía viene a promover al diseño del automóvil como una profesión que combina arte, negocio y tecnología. Identificado con el pensamiento de diseño de Loewy: "Entre dos productos de precio, función y calidad equivalentes, el de más atractiva apariencia externa ganará" 23 . Harley Earl conoce la ley de innovación propuesta por Raymond Loewy en los años 30s acuñada como "lo más avanzado posible pero todavía aceptable"24, la cual sugiere un balance entre lo nuevo y lo familiar, dado que las personas, en particular los adultos, prefieren configuraciones de patrones conocidos y que les resultan fácil para interactuar. Por el contrario, rechazan lo que resulta desconocido. Con una mirada creativa más agresiva, procura conocer lo que espera la gente, aunque no lo expresen de manera consciente, por ello analiza lo que hay detrás de sus historias; sus deseos y preferencias; la experiencia con los clientes de Hollywood en el negocio de su padre le mostró que las personas siempre están aspirando a más, a una proyección ideal de sí mismos en la que puedan sentirse únicos y admirados. Estudia a la competencia para distanciarse de ella e indaga en lo que la tecnología posibilita, no para seguirla sino para forzarla a concretar lo que su estética propone. La consolidación del diseño como el líder de la nueva era de la serie GM de los 50s posiciona al diseñador (stylist) como un sujeto capaz de sintetizar e integrar información compleja y transformarla en una construcción con sentido, mientras interactúa con grupos multidisciplinares para encontrar y resolver problemas basados en datos de verificación. En su naturaleza de socialización de ideas, el proceso demanda del diseñador producir narrativas, metáforas, esquemas que emergen en la realidad presente y en otra imaginada (la de su propio bagaje). En otras de sus máximas Earl afirmó que 'imaginar lo que aún no existe y poder describirlo, es algo que puede llegar a ser concretado'.

\subsubsection{Primer Concept Car}

Acorde con el centro de patrimonio histórico de la General Motors conocido como Heritage Center GM, el Concept car, el auto concepto nace como una iniciativa propia para la exploración estética como medio de anticipación de diferentes apariencias con la visión futurista para el aumento de visibilidad de la marca y de las ventas. Como estrategia propuesta por Harley Earl, se trata del desarrollo experimental de propuestas con foco en la estética del automovil y para la innovación tecnológica en la que se explorarán conceptos futuristas acerca de la apariencia y modos de experimentar la movilidad en este vehículo. Liderado por el equipo de styling se tratará de una división independiente de la de diseño de línea comercial en la que se promoverán nuevos horizontes para el planteo de la 
concepción estética. A cargo del diseño de las propiedades formal - estéticas del cuerpo exterior e interior liderará el marco de la experimentación; lo hará en trabajo colaborativo con otras disciplinas. En su planteo, la creación se hace en correlación con el contexto: institucional y con las personas al presentar en avance modelos que aún no existen. Prototipos que cuentan una narrativa única, con visión futurista y propuesta disruptiva serán expuestas al público para estimular el deseo de compra, obtener retroalimentación para el refinamiento de la propuesta estética y la prevención de fracasos millonarios por el lanzamiento de modelos que no conecten con el mercado. Así la estética va a trazar la pauta para el desarrollo de ingeniería de manufactura como una táctica opuesta a la Ford, su principal rival, en su lógica de costo-eficacia productiva por encima de la concepción de las cualidades estéticas.

Por otro lado, los 1950s son reconocidos como la era dorada para el sector del automóvil en Estados Unidos, constituyéndose en el centro de innovación del diseño; 'autos voladores', motores con tecnología nuclear, dispositivos eléctricos para la automatización. Para los años 1960s el foco de los Concept cars como fase de diseño para la anticipación de cualidades del automóvil se desplaza a Europa. Su propuesta opone a las concepciones de escala, proporción y excesivo ornamento de los americanos; la tradición de líneas suaves, modelos compactos y otras interpretaciones de lujo son eventualmente trasladadas a versions comerciales (Rees, 1999).

Acorde al pensamiento benjaminiano de que hay objetos industriales que poseen un efecto artístico superior a muchas obras de arte, Morcillo (2013) plantea que el automóvil está en esa categoría por la intensidad poética de su imagen, su forma expresiva que entronca el arte, la sociedad, la cultura y la tecnología con impacto emocional y no sólo práctico. El automóvil es considerado el objeto más significativo de la modernidad, y el de mayor conexión emocional con las personas por su apariencia y utilidad (Gartman, 1994; Rae's, 2001; Jaarfarnia, 2013; Morcillo, 2013).

La GM concretó el primer Concept car (o auto de sueño) como expresión de simbiosis estética y tecnológica que intenta romper el paradigma formal instaurado por la Ford y que Earl señalaba como 'cajas sobre ruedas' (boxes on wheels). El Buick Y-Job desarrollado desde 1938 concreta el primer prototipo en 1941. Su fuerza semántica, en tanto producción de significado, inicia con su nombre: Modelo Y; hasta el momento la industria denominaba modelo $\mathrm{X}$ ( $X$-model) a los diferentes desarrollos experimentales, (su estatus de $\mathrm{X}$ es algo aún indeterminado pero exploratorio y secreto). Con Y, es un paso adelante, Job (trabajo) pretende lanzar el mensaje del siguiente paso del trabajador que puede acceder a una nueva generación de automóvil para lograr notoriedad y disfrutar de sus adelantos tecnológicos: cubierta descapotable, vidrios eléctricos, faros ocultos, cromados, ruedas con bandas blancas y en general una apariencia de estatus social, acorde a la ideología de progreso, abundancia y poder. Con este desarrollo del primer Concept car, Harley Earl obtiene en mayo 7 de 1935 la patente 95-496 por la introducción de las luces retráctiles y otros detalles de la apariencia externa alcanzada en ese momento de desarrollo del Y-Job, es decir antes de su concreción.

Al quedar Estados Unidos fortalecido económica y tecnológicamente después de la Segunda Guerra Mundial, impone un cambio de foco: aceleramiento de cambios de la realidad social, de planteo de nuevos planteos en la dimensión estética y tecnológica. Ahora, el pro- 
yecto "Laboratorio Experimental sobre Ruedas" (Experimental Laboratory on Wheels) lo hace posible.

\subsubsection{Ficción y Pensamiento Estético}

La ficción significa cosas que consisten en la representación de aquello que se conoce y de la capacidad de una expresión comprensible y provocadora de fantasía en otros. La apariencia de los objetos resulta de una representación mental cargada de subjetividades particulares que exceden la materialidad armónica configurada originalmente reconocibles como modelos que refieren a los grupos socio culturales que la generan y apropian. Como intención de experiencia estética conculca una manera inconsciente de relación entre imagen y sujeto observador. Con respecto al diseñador en su acto creativo, además de la intencional y consciente, una manifestación inconsciente e invisible del bagaje incorporado a partir de la interpretación de su entorno mental, físico y sensible.

El diseño conceptual como anticipación de ideas, imaginarios, cualidades de la forma es soportado en las narrativas; que incluso, aparecen en prensa: "Creando los autos del mañana...HOY”, esa fuente mayúscula liga a la convicción con que actúa el pragmatismo, a la mentalidad de lo que es posible ahora, a lo que se concreta mientras se va haciendo. La ilustración de 1955 producida por el Equipo de Sueños GM, creativos encargados del diseño conceptual, muestra la idea del aparecer y de la experiencia posible con el futuro vehículo. Esta imagen corresponde al desarrollo del Firebird II: el primer 'auto autónomo', nótese que el conductor, disfruta del entretenimiento que los pasajeros tienen mientras viajan y disfrutan de una vista panorámica del paisaje. Su sonrisa, refleja la tranquilidad que se tiene con un vehículo dotado con computadora interior para la navegación, cuerpo en titanio, motor alimentado por hidrógeno y otras innovaciones que le otorgan la patente industrial, a Earl, Norman James y otros miembros del equipo.

La ficción de GM con sello estadounidense es hacer hincapié en el sueño y la grandeza. La realidad de la vida cotidiana en su concepción estética es una hiperrealidad, es el adelanto de un imaginario, que idealiza y pone en movimiento su genio pragmático para liberar mentes y emociones a través de nuevas imágenes.

La expresión estética significa experiencia y permite la participación interna con relación a las condiciones y el contexto en que experimenta. El aparecer del automóvil como acontecimiento estético, es la manifestación de la presencia sensible, llamativa para los sentidos y la conciencia para experimentar el mundo que trascienden de un modo más subjetivo que cognoscente. Aplausos, sorpresa como manifestación emotiva se aprecian en archivo de las rutas de exhibición realizadas a nivel nacional.

En línea con Zátonyi (2002), la Estética es vista como la esencia humana expresada sensitivamente a la que acuden tres actores que se relacionan activamente: un sujeto materializador (equipo GM), lo estético creado Concept car (una creación simbólica intencionada de contenidos para el agrado y que estimulan al receptor para otorgar múltiples significados al objeto en tanto mediación), y un receptor, sujeto empírico, sensible y dotado de habilidades de comprensión quien pone en juego su propia experiencia y fantasía para otorgar sentido y apoderarse del objeto o apartarse de él, podemos afirmar que, la invención de la forma Concept car GM genera categorías de pensamiento, conceptos, rastros sociohistóri- 
cos y propone un modo de creación de conciencia y de interacción sensible entre sujeto y objeto, el cual, representa la conceptualización de experiencias subjetivas atravesadas por los deseos propios y de otros; por determinaciones sociales, históricas y materiales, con lo cual se trata de una creación estética, una que satisface diferentes clases de necesidades y una, en la que el creador expone su propia ideología o la fusiona con otra de poder.

\subsubsection{Carácter Estético de los Concept Cars}

Earl considera que a través de la estética del automóvil es posible modelar el gusto de las personas. Asociado a la personalidad (character) de los individuos el cual otorga un valor único y de singularidad con el que se distingue una persona de otra, Earl considera que la estética del automóvil es una forma de atribuir carácter. En trabajo colaborativo con otras áreas una de sus mayores contribuciones para el acto de diseño es la fase de conceptualización del carácter estético de la forma, por la cual se atribuye a la General Motors ser la primera compañía del mundo que la establece como una fase estratégica de composición semántica y de esquematización de la figuración para la anticipación del carácter a ser expresado en las cualidades de la superficie material del cuerpo del auto. Los Concept cars representan valores a los que el colectivo adhiere con agrado y otros de singularidad, el desafío como apariencia atractiva no se trata de la simplicidad / organicidad propuesta por Loewy, más bien de una fuerza expresiva, cargada de detalles con valor metafórico alusivos a la anticipación del futuro y el goce de la aeroestética.

Finalizando 1946, Harley Earl y Harlow Curtice se reúnen en la GM para discutir el proyecto Laboratorio sobre Ruedas, allí deciden que los conceptos a desarrollar van a ser más que un logro de ingeniería, una hazaña de estilo. Esto significaría que la índole estética del diseño formal jalonaría las posibilidades de ingeniería para su fabricación.

La apariencia exterior va a la percepción sensible, a la imaginación, más que al discernimiento de las cualidades funcionales del automóvil. En clave kantiana: "Aquello que es meramente subjetivo en la representación de un objeto, esto es, lo que constituye su relación con el sujeto, no con el objeto, es su índole estética (...) para la determinación del objeto (su conocimiento) es su validez lógica" (Kant, 2016a, p. 116). El juicio estético se hace sobre la representación subjetiva, la cual produce un placer y no el resultado del discernimiento sobre su concepto en el sentido de su finalidad utilitaria.

Luego su pregunta es ¿qué es lo que gusta a las personas? Y el Presidente de la GM, Sloan les responde: "Tiene que haber este pionero, el individuo que tiene el valor, la ambición de superar los obstáculos que siempre se desarrollan cuando uno trata de hacer algo que vale la pena, especialmente cuando es nuevo y diferente", "Un auto para cada bolsillo y para cada propósito", así que Earl añade: nuestra estética es un acto de comunicación de nuestras mentes y emoción con las mentes y emoción de las personas; nuestra idea de belleza no dista de la armonía y la buena proporción, lo demás debe ser secreto.

Y serán las personas las que nos indiquen los ajustes a la estética del futuro del automóvil, que aún no han visto. Nosotros nos encargamos del resto ${ }^{25}$. GM tiene el apoyo del estado y requiere adaptarse a la ideología de posguerra que procura la movilización de la economía bajo la promesa de libertad, progreso y democracia. Una estética que simboliza estos ideales en una apariencia atractiva es la vía. El aprendizaje tecnológico con la fabricación 
de armas para la Segunda Guerra con Europa y el Pacífico; descubrimiento y conformación de otros materiales: polímeros, vidrio templado y curvado, metales, vienen a hacer tangible la novedad.

Para los diseñadores GM de los Concept cars la belleza significa una expresión de algo que funciona y que representa una imagen idealizada, compartida y avalada socialmente tanto para el automóvil como para los individuos. Es decir que en su comprensión del contexto y del sujeto, encuentran que es bello algo que no sólo es captado en las cualidades visibles e invisibles de la forma, sino que, a través de su apariencia, le permite al sujeto proyectar una imagen de cómo quiere verse, y cómo quiere ser visto a través de ese objeto: automóvil. Pero en lo que concierne a la belleza atribuida al auto por su forma, puede aumentarse mediante el estímulo para interesar más el ánimo mediante la representación del objeto y servir así para la alabanza del gusto y de su cultura, aunque aún sea tosco o rudo, pero capaz de producir emoción. Esta emoción es una reacción momentánea a pulsos efectos de vivificación de atributos formales como la línea, el color y la textura. También el uso de adornos como elementos añadidos, no estructurales que captan la atención de la mirada sin que hagan parte constitutiva interna de la representación del objeto. Kant les categoriza como ornamento y señala que estos contribuyen a la satisfacción estética; cuentan como propiedad formal para enjuiciar la belleza atribuida, la que concierne a lo agradable y no a la belleza pura ni al juicio del gusto puro. Y argumenta: el juicio puro del gusto no tiene como fundamento de determinación ningún sentimiento: la emoción es reacción momentánea de sensación agradable y placentera, por su parte el afecto, un sentimiento permanente y deliberado que se alimenta de razón y memoria. En ese sentido, la estética del automóvil es una expresión performativa que invita al sujeto en su experiencia con él, para sumar memorias, imágenes y fantasías que construyen el afecto del sujeto.

La creación de belleza del objeto, precisa la producción de ideas estéticas, aquellas representaciones de la imaginación. La imaginación como capacidad productiva, faculta al diseñador para tomar distancia del concepto racional, utilitario para crear los atributos estéticos del objeto, los cuales pueden entenderse como los rasgos que definen su valor sensible. De manera complementaria, el discernimiento estético, en el juicio de lo bello, refiere la imaginación en su libre juego para coincidir con sus conceptos, ideas determinadas de lo que el "objeto debe ser", en otras palabras, hay una intervención de la razón para compatibilizarse subjetivamente con las ideas y disponer el ánimo positivo frente a la imagen de la forma. Lo objetivo y lo subjetivo, lo práctico y lo sensible, la razón y la sensibilidad se hacen manifiestas como tensiones estructurantes de la concepción del sentido estético.

\subsubsection{Aura}

Su búsqueda de una imagen del automóvil sin precedentes con sello de autenticidad es soportada en el imaginario futurístico de la aeronáutica, la ideología, la expansión vial, de las ciudades y el pensamiento GM. Con la introducción de novedad de los Concept cars se logró hacer sentir a las personas, miembros del acontecer social, empoderados en sus formas de relacionarse y proyectar una imagen individual, valores que prevalecen en la cultura estadounidense (Gartman, 1994).

Si se compara el fenómeno GM Concept cars con el planteo de Walter Benjamin (1973) en La obra de arte en la época de su reproducibilidad técnica afirma que la autenticidad de 
la obra artística, explicitada como "aura es la cifra de todo lo que desde el origen puede transmitirse en ella, desde su duración material hasta su testificación histórica” (En Morcillo, 2013, p. 44). Es equiparable a la fuerza expresiva de la apariencia que plantea, GM. También la asocia a la función ritual de la obra en el sentido -de Benjamin-que, a través de su contemplación y reconocimiento, obtiene una integración social. El Concept car en su versión comercial no sólo se integra a la vida cotidiana, sus rituales sociales, sino que hace parte de la cultura material, de la imagen que circula en el entorno.

Setenta años después, son exhibidos en museos de arte del mundo, son piezas valiosas de coleccionistas, tesoros de quienes los poseen. Benjamin reconoce en el ornato y el detalle, un detalle de autenticidad en la manifestación del objeto. Para Earl, la riqueza en el detalle, la fricción de elementos compositivos es un rasgo del carácter único y de distinción de los antecedentes, en su intención estética, se trata de encontrar más detalles en cuanto más se observe el cuerpo del automóvil. Así que, puede inferirse que hay una similitud del carácter estético con el aura propuesta por Benjamin.

\subsubsection{Autorreferencia}

El aura se interpretó como aquel carácter que otorga al objeto un poder de saturación en el mensaje; ornamento y detalle en su aspecto y una presencia social tal, que le hace permanecer en el tiempo. Con la autorreferencia aludimos a la manifestación de rasgos propios y novedosos que el diseñador en su autonomía aporta al carácter estético de la forma sin detrimento de representación de su conexión con el contexto. Los Concept cars de la GM además de autos de sueños, 'un auto para cada bolsillo y para cada propósito' se conciben como una manifestación única en su esencia formal para estimular la curiosidad, atención y experiencia estética del espectador. Esa manifestación de novedad es la que Mukařovský (1978c) promueve como el verdadero sentido de la creación estética porque de lo contrario se estanca en la presentación de lo determinado.

Un ejemplo de este carácter con aura y autorreferencia es la concepción metafórica del Cadillac El dorado Biarritz 1959: concebido como un símbolo de prestigio en la vida urbana, representa poder, abundancia-exuberancia y glamur-deseo, es el avión de guerra P-38 Lightning Fighter, un referente que simboliza ataque y confiabilidad, inspira el diseño GM el cual explicita como expresión de belleza sólida y duradera, un mensaje de determinación y confianza para el avance social y bienestar material.

En las siguientes imágenes se pueden apreciar perspectivas: el avión P-38 Lightning Fighter (Figura 1) y el Cadillac El dorado 1959 (Figura 2) la similitud del cuerpo del automóvil: 


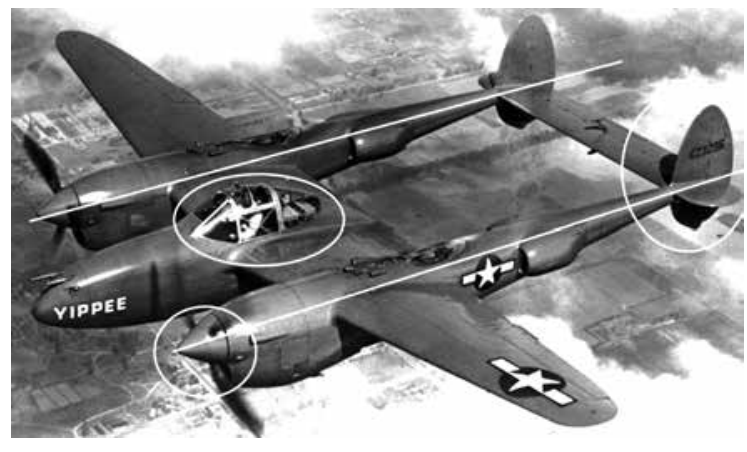

1

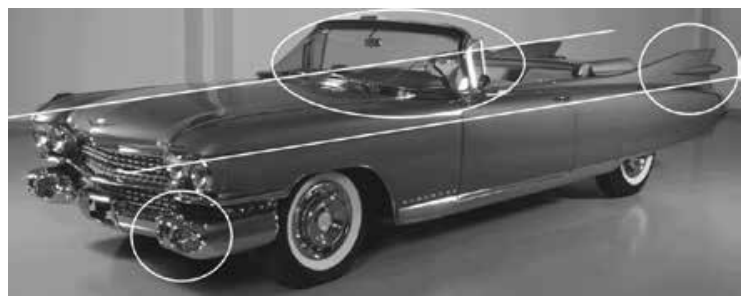

2
Figura 1. Foto de Avión P-38 Lightning Fighter (1944) Fuente: https://www. thoughtco.com/ world-war-ii-p-38lightning-2361085.

Figura 2. Foto de Cadillac El dorado Biarritz 1959. Fuente: GM Heritage Center.

Con respecto a longitud y distancia entre ejes: más largo que ancho, silueta más baja, paragolpes y rejillas masivos, panorámico en vidrio curvado con boceles metálicos (tipo cúpula avión); líneas sinuosas de carácter orgánico y aerodinámico. Altas traseras prominentes en forma de proyectil. Predomino de texturas lisas, brillantes y color vibrante marcan otros valores de representación en el valor aspiracional y de lujo para la marca Cadillac. En concordancia con su idea de 'un auto para cada bolsillo y para cada propósito' y un sello de autorreferencia, este Cadillac Eldorado Biarritz desarrolla una serie presentada en el portafolio original de la GM Cadillac 1959 'Sixty-Two Sedan' con seis ventanas (mayor visibilidad hacia exterior e interior), luego 'El Dorado Biarritz' es convertible y el Fleetwood-Sixty Special presentado como el modelo más lujoso tipo limosina, posee un techo rígido como rasgo para la privacidad.

\subsubsection{Aeroestética y Entretenimiento}

Para mediados de 1945, la GM concibe en su pensamiento estético que las cualidades del aspecto del automóvil deben presentarse como una expresión artística, un acto de entretenimiento en el que se aviva el ánimo de los espectadores mientras captan una forma metafórica que representa la anticipación del futuro del automóvil. Sus mejores referentes simbólicos fácilmente comprensibles fueron las aeronaves de guerra, así que una suerte de 
aeroestética emerge para desplazar líneas, escala y proporción, cúpulas, proyectiles, aletas, punteras, desfogues, materiales al aspecto del vehículo. Códigos reconocibles en una construcción semántica que conecta con la utopía que vienen concretando.

El gusto por lo hiper se desliza a este Concept car estadounidense, el imaginario social de superioridad, abundancia y grandeza que representa su identidad. Su preferencia por la estética exuberante de los automóviles, las casas, otros objetos cotidianos y sus comidas, es signo de ello (Gartman, 1994). Por su parte, George Walker ${ }^{26}$ (1962) afirmó que el público estadounidense es agresivo, se mueve hacia arriba todo el tiempo y eso significa negocios. Cuando el trabajador estadounidense tiene bajo ingreso, quiere una casa más grande y un auto más grande.

El consumo es un modo de adquisición de prestigio y su atractivo estético yace en la proyección de una imagen del individuo y no sólo del objeto que se posee. El automóvil comienza a ser una extensión de la imagen personal y de distinción social que se posiciona en la mente de los otros. El orgullo del Sueño de Vida Americana (American Dream Life) es la convicción íntima y delirante de haber materializado todos sus sueños. A lo que Baudrillard (1986) agrega que para la América de los 50’s y 60’s no se trata de libertad e igualdad sino libertad de hecho, el acento de la capacidad individual para mostrar supremacía en su logro mientras los franceses prevalecen en su preocupación por las apariencias, el reconocimiento intelectual y su distingo de clase.

Para GM la estética del automóvil tiene una naturaleza relacional entre el sujeto y el objeto, su interés comercial hace que tanto los contenidos de cualidad del aspecto del automóvil como de su aparecer tengan igual relevancia 'la ceremonia de consumo'. La feria itinerante Motorama 1949 a 1961 denominada 'Transporte sin límites' (Transportation Unlimited) abierta en el Hotel Waldorf Astoria de Nueva York, tuvo su primera versión en 1949. Acogió cerca de medio millón de personas interesadas en nuevas ideas; un espacio de ilusión y fantasía para mover el agrado e incidir en la compra de los modelos. Allí la aeroestética y el entretenimiento se juntan para el aparecer de las nuevas apariencias de los Concept cars. Con los diseñadores GM allí presentes, se captan reacciones, opiniones de las personas que permiten refinar tanto concepto como figuración de su propuesta estética.

Esta feria itinerante catalogada como un fenómeno cultural expresado en el show ${ }^{27}$ de autos glamorosos de la GM, presenta los prototipos de Concept cars como Motorama Cars (Temple, 2015). En imágenes de archivo puede apreciarse la contemplación que hacen las personas del automóvil y de todos los recursos de mensaje simbólico que allí se ponen en escena: la imagen atractiva y sofisticada de la modelo, la elevación del cuerpo del auto, su aparecer como sí se tratase de una pieza artística tienen como propósito exacerbar las emociones para captar la atención en el interés por lo desconocido y la ficción dada en la metáfora del auto como 'objeto de deseo'.

Gartman en su libro Auto Opium (1994) describe el fenómeno de la estética del automóvil estadounidense equivalente al opio de la religión en la tierra para la población de Estados Unidos; alcanza el nivel de objeto ritual para su sociedad. En su análisis de perspectiva histórico-sociológica afirma que la apariencia de este objeto representativo de la sociedad de consumo, de la reproducibilidad técnica, penetra el imaginario social, se convierte en el objeto que mueve de manera más potente las emociones de los individuos y el modo en que ellos se relacionan; atribuye también a la relación sujeto - automóvil un modo de 
proyección de estatus social, más significativo que el que alcanzan con sus casas, porque éstas no se mueven con ellos.

\subsubsection{Narrativa de los Concept Cars}

Earl plantea estimular la mente de los espectadores hasta los límites de la imaginación en que los sueños de hiperrealidad se realizan en una realidad material: el automóvil. Cada modelo tiene su propia narrativa ${ }^{28}$, una que no emerge sólo de las memorias e imaginación del diseñador, del esquematismo que hace de los símbolos e imaginarios del campo en el que opera y de las historias que obtiene de las personas en su interacción con ellas y en su proceso de co-creación a través de Motorama.

Cada narrativa evoca y procura conectar con la proyección de su futuro conductor y del entorno de experiencias que vivirá con su Concept car. En su habilidad de producción semántica reúne símbolos e imaginarios con mezcla de metáfora y ficción; es decir combina realidad presente y la imaginada como anticipación del futuro. Mostar algo que remite a otra cosa, mezcla de precedentes y expresión única o de autorreferencia.

Cabe resaltar que los diseñadores GM deben mantener su acto creativo en secreto, evitar fuga de información a la competencia, implica no sólo trabajar en su laboratorio de ventanas oscuras y a puerta cerrada, también la fragmentación de la información que compone cada modelo.

Earl afirma que desde 1933, su experiencia de escuchar historias de las personas con respecto a sus gustos, memorias e ideales sociales, alimentan las suyas y mejoran los conceptos. "Como objeto de deseo, el automóvil posee un carácter de singularidad que representa valores aspiracionales de las personas, aunque ellas no siempre sean conscientes de ello" (Earl, 1957). Y menciona que el diseño como acto de comunicación metafórica expresa aquello que las personas desean simbolizar en su entorno de sí mismas, aunque ellas mismas no sean conscientes de ello; por ejemplo: reposicionamiento social o una imagen más glamorosa que capte la atención de otros.

Argumenta que Motorama como un espacio del aparecer de los Concept cars hace de cada uno un laboratorio único para percibir directamente lo que agrada o no a las personas e incluso de expresar preferencias que ellos mismos no conocían. Una oportunidad de leer los símbolos que circulan a través de su lenguaje corporal y reacciones. En 1954, menciona que las mujeres pedían a sus esposos autos convertibles porque les gustaba como lucían, aunque detestaban despeinarse. También notó que las personas de clase trabajadora concentraban su atención en modelos proyectados a segmentos de capacidad económica superior a las suyas; 'el auto del jefe'. Earl promueve evolución, tanto en el concepto como en la apariencia. No pretende socializar el orden simbólico o de la ideología; el contexto sociológico es un campo experimental en el que apariencia, aparecer y modos de experimentación del automóvil fuerza los límites de lo normado; con el auto no sólo se refleja una posibilidad competitiva, se proyecta la imagen de los individuos y de la nación estadounidense.

Earl está convencido que el diseñador no sólo cuenta, sino que crea buenas historias e indica que el diseño implica persuasión ${ }^{29}$. Así que la narrativa en cada Concept car puede interpretarse como una historia que habla de una imagen autorreferente idealizada y sensible del sujeto proyectada en el contexto a través del objeto. 
Una posición compatible con el pensamiento de Mukařovský (1978), para quien la reinvención del arte produce un aumento de la comunicación, que es el significado de lo que es la estética; un mecanismo simbólico estético que genera evolución. Lo contrario, la bloquea inevitablemente con un orden normalizado. Y tanto sujeto como objeto tienen una participación; se trata de un intercambio de información entre los dos para hacer emerger una nueva.

$\mathrm{Al}$ interior de GM se discute la ruta de lo conocido a lo desconocido para los Concept cars. Producir manifestación única, sin precedentes; procesar la información que se posee, obtener sus representaciones, significantes y figuraciones para transformarlos en mundos imaginados con rasgos reconocibles. Inspirado en aviones a reacción, el Concept Buick Le Sabre 1951 posee un altímetro, sus líneas y detalles de sus secciones: delantera (parrilla, guardabarros) y trasera (luz central, accesorios como cohetes y figura del tanque de gasolina) derivan del avión caza F86 Sabre, el azul plata y cromados evocan su elevación al cielo. Una abstracción morfológica del cuerpo y otros detalles del avión pueden apreciarse en las diferentes imágenes del cuerpo del Buick Le Sabre. Su logo USA es un sello de marca nacional y un mensaje de lo que ya se anticipa. La inclusión de las banderas francesa y estadounidense en el lateral trasero, son un mensaje de amistad expuesto en La feria Internacional del Automóvil, Paris 1951. En las líneas de color (rojo y azul) de los rines, puede apreciarse el refuerzo de este valor simbólico.

\subsubsection{Principios de Experiencia Estética}

Hemos dicho que el equipo GM de diseño procura una experiencia placentera de las personas con la apariencia de sus Concept cars. Para comprender la experiencia estética, se puede mencionar a Hekkert 2006, quien desarrolla en el marco de la estética del diseño cuatro principios de placer en la experiencia del producto. Primero, distingue tres modos de experiencia que se hacen presentes en la interacción sujeto - apariencia del objeto:

1. Experiencia estética: estimulación sensorial y su gratificación.

2. Experiencia de significado: los significados atribuidos al mensaje de su apariencia.

3. Experiencia emocional: los sentimientos y emociones que se generan por la conexión entre el mensaje de la apariencia con memorias y valores de la persona. Estos procesos facultan el reconocimiento de las metáforas, asignar carácter y un valor personal al objeto. La asignación de significado no es una actividad exclusiva de la mente, sino que está asociada a procesos sensibles de tipo emocional que pueden leerse incluso, en la expresión facial y corporal. Los mensajes captados por las personas y su valoración dependen en alto grado de su interpretación y de la adecuación simbólica de lo expresado en la forma.

Luego, desarrolla cuatro principios de naturaleza evolutiva tanto para el medio como para el tiempo, sin que ello pretenda un acuerdo estético universal. A saber, son:

1. Máximo efecto con el mínimo de medio, alude a un alto poder expresivo sin que ello implique un esfuerzo cognitivo importante para el espectador. Con respecto a parámetros de composición refiere más a una adecuación con el entorno que a la reducción de líneas 
o detalles. Lo que se busca evitar es la ambigüedad o la distorsión porque en línea con la ley MAYA una desviación considerable pasa a ser rechazada. La metáfora es para este principio un recurso eficaz de expresión para conectar con las emociones y que además ofrece una cierta libertad 'guiada' de interpretación. Una representación simbólica de reconocimiento visual.

2. Unidad en la variedad, conecta con leyes perceptuales de estructura y se centra en la ordenación de elementos de cierre y contraste. Su foco es la percepción de la unidad armónica antes de la discriminación del detalle.

3. Apropiando la ley M.A.Y.A. de Loewy releva el balance de novedad - familiaridad y agrega desde el punto de vista psicológico que las personas se mueven entre la adaptación a lo que conocen y la curiosidad por lo nuevo; la novedad como algo extraño ofrece riesgo, por ello las personas prefieren asumirlo de manera progresiva. Este es un principio desafiante porque el bagaje de las personas con relación a su gusto varía; es decir que personas, con mayor exposición a diferentes propuestas estéticas y entornos, serán más abiertas a nuevas posibilidades. GM junta composición narrativa y figurativa mezclando simbolismo-imaginario y ficción.

4. Principio de coincidencia óptima, implica una congruencia tanto en la estructura compositiva como del mensaje que es captado por las personas para facilitar su conexión favorable. La dimensión semántica y la composición morfológica se corresponden como concepto, aspecto y sentido para las personas. La consistencia y coincidencia de los cuatro principios, según Hekkert favorece la valoración estética de la apariencia del objeto en su experiencia con el sujeto. Desde la praxis de los diseñadores de los Concept cars, se interpretan como tensiones entre: novedad - familiaridad, adecuación - originalidad, figurativo - simbólico, identidad - aspiracional, ficción y realidad.

\subsection{Pensar Estético del Diseño Concept Cars ¿Kitsch?}

Con respecto a las relaciones entre lo kitsch y el objeto, Abraham Moles y Eberhad Wahl (1991) inscriben el término kitsch de origen alemán verkitschen en hacer una cosa por otra, una negación de lo auténtico por una expresión de antítesis en la génesis estética; una forma de 'anti-arte' e indican que corresponde a una génesis estética que ubica al objeto en otras dimensiones con relación al ser; se desplaza su funcionalidad o apariencia tradicional, e incluso acude a referentes externos al de su categoría conceptual. Los autores indican que el kitsch es inherente a la producción de arte, pero migra a la de objetos y su visibilidad se manifiesta más o menos según condiciones de la sociedad y los patrones de gusto vigentes.

El kitsch entendido como lo que va en contra del buen gusto representa una expresión disruptiva y a la vez un sistema estético de comunicación de masas cuyo valor principal es su aptitud para producir placer, ese que no requiere de discernimientos lógicos y el cumplimiento de lo normado. Su detección se manifestó con intervenciones del diseño en función de lógicas diferentes a parámetros artísticos y más en dirección hacia la mercancía en la sociedad burguesa, pero sobre todo a un deseo de expresión autónoma, argumentaron. 
El objeto kitsch tiene como manifestación propiedades disruptivas que pueden notarse en su geometría, propiedades formales, modos de uso, traslado de conceptos de unas categorías externas a otras de objetos; un modo de resignificación que implica una reacomodación de patrones de apreciación para las personas. Sus valores de heterogeneidad y tensión estimulan la exploración de novedad en la expresión del diseño y mueven la fantasía para promover nuevos paradigmas de apreciación de belleza. La belleza en el kitsch se manifiesta desde su estructura interna y no por su adecuación por los preceptos compositivos porque ahí resulta un orden lejano.

Los objetos kitsch no pueden construirse en forma exclusivamente racional sino incorporando un alto grado de gratuidad: poseen una suerte de universalidad heterogénea. Desde el punto de vista de la teoría de la información, agregan a la semántica de la funcionalidad, un campo de libertad estético basado en una connotación particular de las relaciones entre el hombre y el medio (Moles y Wahl, 1991, p. 119).

Para ilustración de lo postulado por los autores, podemos citar la narrativa del Concept car Oldsmobile Golden Rocket de 1956 como un modo de resignificación que implica una reacomodación de patrones que vienen de lo aeroespacial y se deslizan al vehículo: ¡Cohete de Oro experimental de Oldsmobile! Cuerpo mucho más bajo, dramáticamente poderoso, con nuevas líneas impresionantes para quedarse sin aire. Aquí está la elegancia supersónica para excitar una gran imaginación. "Cohete de Oro” ¡el automóvil experimental que hace realidad los sueños de los diseñadores de una manera emocionante hoy! Una construcción semántica con alto valor metafórico, adjetivación, deslizamientos de impulso a la ficción en un campo de libertad estética.

La manifestación de lo kitsch es abordada como un modo de estilismo que se posiciona en el expresionismo, en el que: la fantasía es más característica que la racionalidad, hay variación de patrones canónicos; un modo de surrealismo explorado en la experiencia estadounidense, especialmente en los 50s en la que los binomios: "artista - aplicado" y una "actitud: consumidor - rey" es un arte de vivir y un modo de ser y expresar que, no emerge de una funcionalidad profunda sino de la búsqueda de otras maneras de vivir y de relación con el entorno, especialmente en la clase media o burgués. Una de las explicaciones de la acogida de lo kitsch en la clase media, es una coincidencia de fricción entre lo determinado y aceptable con la búsqueda de una voz propia; es divertido y ofrece autenticidad (Moles y Wahl, 1991, pp. 123-127). Otro valor destacable de lo kitsch es la profusión, para referir a la exuberancia en el mensaje, la libertad en la expresión del detalle, el contraste y la alegoría de abundancia (en el sentido de "cuanto más mejor") como momento de la sociedad en la que se desarrolla. Sí bien el cuerpo del Oldsmobile Golden Rocket 1956 no acude a la recarga de elementos, sí lo hace en la proporción de sus elementos de valor simbólico, por ejemplo: la sección lateral que remata en la puntera trasera tipo proyectil y en lo ficcional de su anuncio: 'un estilo de vida supersónico, elegante y sensual'.

La apreciación estética, se mueve en la dicotomía de lo aceptable - inaceptable. En entornos de creación de nuevos paradigmas es una tendencia que se alinea con el espíritu humano y su naturaleza cambiante; para los puristas, es un modo de desarticulación y 
ruptura de postulados de composición formal y de lógica funcional que implica un nuevo tipo de relación con las cosas, un anti - arte. Su propuesta, puede ser vista como kitsch dulce o como kitsch agrio (süsse und saüre Kitsch); el primero puede ser favorecido por su adecuación al gusto, mientras que el agrio como desviación y extrañeza es rechazado. Por ejemplo: este modelo representa una desviación de las composiciones arquetípicas del frente del auto: luces laterales, rejilla central, guardabarros, placa de identificación no se reflejan en este Concept car con respecto a los arquetipos. Bajo el supuesto de que el Oldsmobile Golden Rocket 1956 encarna el kitsch agrio, el reto del diseñador es hacer que la novedad disruptiva de la imagen externa del objeto sea en la narrativa una representación mental y material auténtica con rasgos de familiaridad (o viceversa) para el goce de su audiencia. Un irrealismo o hiperrealismo de dimensiones, amontonamiento de detalles que se traducen en la felicidad del objeto.

Lo kitsch representa un acto de deslizamiento desde la imitación a la imaginación. Se permite la mezcla de rasgos reconocibles con otros inusuales para el concepto funcional del objeto: en este modelo la morfología del cohete migra al lateral trasero del automóvil o la 'trompa' de aeronave reemplaza el estándar de rejilla central del frente.

Tipológicamente hablando, secciones definidas y no necesariamente cuerpo fragmentado; carga de detalles con mensaje simbólico y fuerza expresiva, contraste de colores y o paleta vibrante, mezcla de proporciones en una misma unidad, son algunos de sus rasgos. El valor estético pone la finalidad práctica como secundaria, con exageración intencional para marcar su punto focal. La belleza es más una manifestación de su narrativa que su adecuación a una composición canónica de la forma. Para Moles y Wahl rasgos de lo exótico y de la ficción que el objeto comporta y que puede ser intencionalmente compuesto por el diseño o inconscientemente obtenido desde el propósito de estimular una actividad emotiva en su contemplación o interacción con el objeto.

Un ejemplo de ficción y libertad en la expresión del mensaje es: El Buick Cyclone 1959 (figura 3) Harley Earl y su diseñador Carl Renner continúan la serie aeroespacial con acentos de armas de guerra. Este concept car es una mezcla de auto deportivo, dotado con dos sillas, cuerpo aplanado tipo lancha de donde provienen escala y proporción, y un carácter de auto tipo cohete, profusamente marcado en sus laterales.

Moles y Wahl acopian cuatro principios del kitsch para comprenderle como fenómeno de composición estética, el sentido de la relación dialógica que establece entre la apariencia interna y externa del objeto y con el sujeto y el entorno. En tanto propuesta que se inserta en un momento socio histórico tiene recepción sí hay una suerte de adecuación o apertura de su audiencia a su propuesta de frenesí. Su composición externa habla del Cyclone que en su andar deja un halo, mueve el aire y el polvo mientras corre. Más que una promesa de velocidad una ficción de conquista de su propia atmósfera. En la (figura 4) se aprecian cuerpo y puntos focales. 


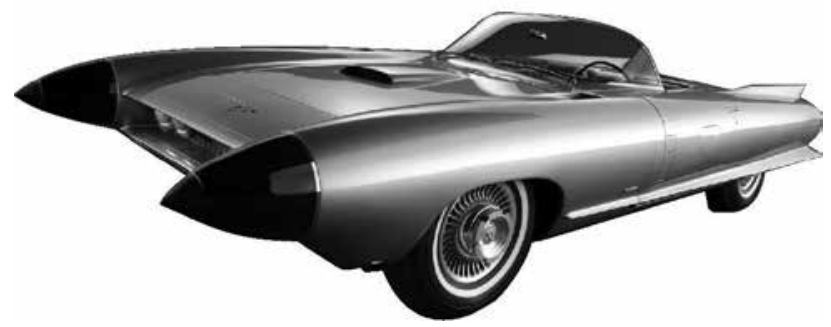

3

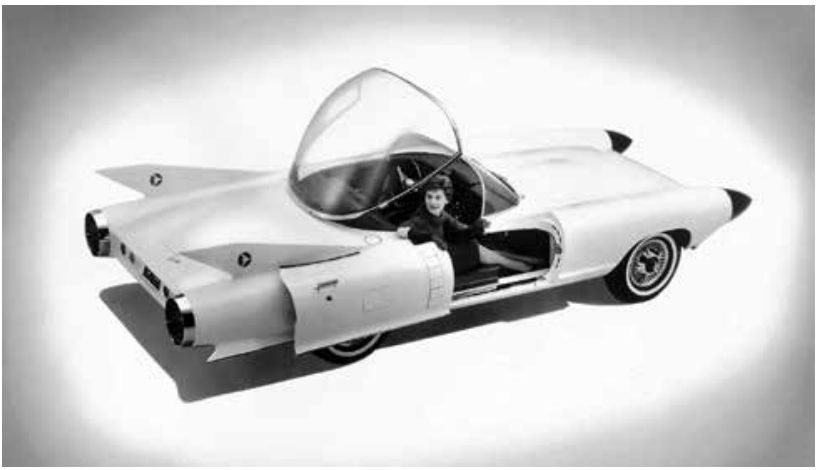

Figura 3. Foto

del Concept car

Buick Cyclone

1959. Perspectiva

Delantera. Fuente:

GM Heritage Center.

Figura 4. Foto del

Concept Car Buick

Cyclone 1959.

Detalles Cuerpo.

Fuente: GM Heritage

Center.

En tercer lugar, el principio de sinestesia se trata de la multiplicidad de elementos para la estimulación simultanea de lo sensorial, lo sensible y lo cognitivo; la presencia de adornos y elementos de contraste son un recurso de hiperestimulación. De atrás hacia adelante, prominentes escapes, aletas tipo aeronave en la zona superior y tipo proyectil en la zona baja. El techo se configura como la cabina de avión con la misma posibilidad de desplazamiento, logrando no sólo una vista panorámica sino el acento de su carácter estético. Otro detalle de sorpresa y disrupción es la puerta corrediza y el tratamiento de su superficie. El cuarto principio es llamado el de mediocridad; bajo su perspectiva, lo kitsch es un modo de perversidad estética, funcional que se inserta en las masas, sin que realmente constituya novedad (en el sentido de avance), sino más bien una imposición de engaño favorecida como fenómeno de moda. Se reconoce que rompe la regla, sin que se constituya como un nuevo precepto de belleza en el sentido canónico, sino en una apariencia agradable, heterogénea que mueve el placer y las emociones en las masas.

La denominación 'mediocridad' puede ser rebatible desde la posición de Gert Selle (1983) en la reflexión que presenta para el contexto alemán: ¡Esto no es Kitsch, es solo diseño! en la que propone revisar el criterio usual del diseño y hacer una apertura a todo tipo de diseño 
sin condena de su propuesta estética o funcional sin pretensiones de adoctrinamiento y mayor observación de su propuesta dialógica con las personas para la conexión con ellas. Selle hace un llamado a comprender la cultura real del producto, su presencia masiva en la vida cotidiana de las personas en donde lo vivido intensifica el mensaje estético del diseño; la cultura no es un continuo y el gusto de las personas ya no, es más, algo guiado exclusivamente por los diseñadores, cada individuo tiene su propia vía de experimentarlo. En la Modernidad el objeto industrial de uso cotidiano exageró su expresión plástica y las personas cambiaron y han madurado sus propios criterios para el goce estético; muestran fascinación por lo heterogéneo, lo diferente e inesperado y no desempeñan un rol pasivo en la fantasía estética, la proyectan en su persona, espacio vital y los objetos de mayor contacto en su entorno. Pretender el control sobre ello es ignorar de manera arrogante e irreflexiva que los criterios de preferencia no siempre están alineados con la idea de belleza trascendente. Los preceptos del buen diseño, institucionalizados en la educación del diseño cuyo interés es normativo, debieran reconsiderarse (Selle, 1983).

Salir de la acepción del kitsch como una evaluación peyorativa del diseño, de perversidad estética o mediocridad performativa para apreciar la libertad de la fantasía estética, aumentar la comprensión del gusto de las personas y lo vívido de su experiencia estética. La presencia masiva de los objetos cotidianos ofrece mayor entendimiento de la belleza como manifestación externa de su estructura interna y de las capas de significado que las personas le agregan. En los objetos de tipo masivo puede inferirse más la apreciación de belleza para las masas que en las expresiones de lujo de diseño al que accede sólo una minoría y que suelen tratarse como piezas de arte. Se precisa poner en crisis la ideología de eventos kitsch versus buen diseño que condenan propuestas de novedad y otras formas de expresión del diseño y que, en todo caso, también generan placer a las masas, señaló Selle. Con respecto a la experiencia estética, el juicio del gusto se aplica al objeto con respecto a la satisfacción y a la belleza libre de conceptos que se conocen mediante una sensación. Lo que marca es la armonía de las capacidades cognoscitivas y una relación objetiva - subjetiva entre sí; por un lado, unas leyes universales de percepción, por otra la valoración de una coherencia interna que conecta lo interno con lo externo. El problema para el diseñador es promover la vitalización de imaginación y entendimiento en una sensación con ocasión de la contemplación del objeto y lo que este es capaz de transmitir a través de sus cualidades en la actualidad del tiempo que opera.

En su conexión con el contexto, el diseño de los Concept cars tiene una correspondencia con otras manifestaciones que en su mensaje apelan a un deseo anhelado expresado como significante; por ej.: la publicidad Mc Donalds vanguardista de la franquicia de comida rápida o estación de comida, promete la satisfacción del deseo por medio de la adquisición de un producto con las cualidades deseadas; baja el tono de la racionalidad funcionalista del valor utilitario a beneficios de necesidades blandas o emocionales en el sentido de la Psicología. La concepción de aviso Mc Donalds responde a la 'percepción veloz', el 'placer de comer dentro del auto mientras socializas' alineado a una nueva velocidad social y cambio en la infraestructura y el transporte, se posa en el camino para ser interceptado por sus comensales. La expresión kitsch es performativa, con fuerza evocadora y de metáfora acompañada de una atractiva adjetivación, releva el valor del ornamento y la profusión. 
En línea con Zátonyi (2002) el kitsch más que un objeto, es una actitud; más que una estructura normada de composición es una expresión que desplaza lo que para otros es inaceptable o transgredidle en un concepto elaborado que mezcla lo que otros han sustraído, lo que está instituido con un relato propio que en todo caso tiene algo de fascinante.

Otra característica de la propuesta kitsch es que se trata de un concepto que tiene validez en su construcción interna como algo que se construye en adecuación de su tiempo y sus condiciones. "El kitsch siempre se arma de buenas excusas. Jamás carece de algo aceptable, reconocible, aunque eso sea cuestionable o debatible. Entre otras excusas se destaca la utilidad, lo pragmático" (p. 208).

El fenómeno kitsch puede tomar ideas, apariencias, significaciones de otros escenarios o aplicaciones prácticas y desplazarlas a otras diferentes. El punto de anclaje radica en que su mensaje posee señales con las que las personas pueden identificarse, apela a lo fantasioso, a lo subjetivo. Al operar con sus imágenes sugestivas moviliza reacciones emotivas; en sus rasgos de originalidad, de disrupción, encuentra una manera de conectar con quienes desean distinguirse o resistirse a lo normado. O simplemente resaltar su individualidad, aunque sea interpretado por algunos y en palabras de Zátonyi a 'hacer muebles nuevos con muebles viejos" (2002, p. 196).

Una vía de expresión con la que el diseño, puede encontrar puntos de intersección con las personas; forma y contenido en lo kitsch permiten diferentes modos de hibridación que adquieren consistencia cuando el mensaje interno y lo expresado por la imagen hablan de lo mismo.

\section{Conclusiones Parciales:}

1. El pensamiento estético de la GM es una construcción mental, intencional y performativa que surge de organizar ideas, representaciones de la realidad presente y otra imaginada para concebir el carácter de autorreferencia a las cualidades de la apariencia del automóvil. Como testimonio del tiempo y espacio en que es creada, posee códigos compartidos con los individuos para poder comunicarse y sostener el nuevo sentido propuesto.

2. Lo objetivo y lo subjetivo, lo utilitario y lo atractivo, la razón y la sensibilidad se hacen manifiestas como tensiones estructurantes de la concepción del sentido estético.

3. El pensamiento estético GM de los Concept cars posee rasgos de ficción, representación de valores de identidad, simbolismo de los imaginarios y figuraciones propias del concepto del automóvil como rasgos reconocibles, pero también deslizamientos de referentes propios de otras expresiones de diseño.

4. La estética del automóvil tiene una naturaleza relacional entre sujeto - apariencia del objeto para conectar más con su sensibilidad e imaginación que con su entendimiento. En ese sentido, la estética del automóvil es una expresión performativa que invita al sujeto en su experiencia con él, a sumar memorias, imágenes y fantasías que construyen el afecto del sujeto hacia el objeto.

5. La apariencia estética del automóvil posee un carácter distintivo como resultado de una producción de narrativa y de composición formal con fuerza evocadora en su mensaje metafórico, la riqueza de detalle y el contraste. Así que la narrativa de cada Concept car 
puede interpretarse como una historia en contexto que habla de una imagen autorreferente idealizada y sensible del sujeto proyectada en el objeto.

6. Para el pensamiento estético GM de los Concept cars, se trata de la apariencia y el aparecer del objeto como par inseparable en la experiencia estética. Un juego de intercambio que debe ser entretenido para estimular las emociones más que el discernimiento.

7. La creación de belleza del objeto, precisa la producción de ideas estéticas, aquellas representaciones de la imaginación. La imaginación como capacidad productiva, faculta al diseñador para tomar distancia del concepto racional, utilitario para crear los atributos estéticos del objeto, los cuales pueden entenderse como los rasgos que definen su valor sensible y coincidir con sus conceptos, ideas determinadas de lo que el "objeto debe ser".

8. Para los diseñadores GM de los Concept cars la belleza significa una expresión de algo que funciona y que representa una imagen idealizada, compartida y avalada socialmente tanto para el automóvil como para los individuos. Es decir que en su comprensión del contexto y del sujeto, encuentran que es bello algo que no sólo es captado en las cualidades visibles e invisibles de la forma, sino que, a través de su apariencia, le permite al sujeto proyectar una imagen de cómo quiere verse, y cómo quiere ser visto a través de ese objeto: automóvil.

\section{CAPÍTULO 3: ACTO DE DISEÑO DE LA ESTÉTICA DEL OBJETO}

\section{Acto de Diseño de la Estética del Objeto}

Bajo la pregunta ¿Qué caracteriza el acto de diseño de la estética de los Concept cars GM? este capítulo denominado Acto De Diseño de la Estética del Objeto parte de la hipótesis de que el acto de diseño se caracteriza por un conjunto de operaciones intencionales y condicionadas para la construcción progresiva de una estructura de contenidos que determina la esencia o carácter y anticipa las cualidades formales de la estética del objeto.

El diseñador, soportado en su pensamiento, intercambio con el contexto y su habilidad proyectual $^{30}$ aporta su voz en el mensaje que expresa a través de la forma para su resonancia emocional y de quienes la aprecian.

En el marco de pensamiento en acción del diseño para la estética del objeto se van a caracterizar las operaciones de esquematismo del contexto, de diseño conceptual para inferir el conocimiento tácito $^{31}$ de su práctica o know how y que pueda ser explícito a través de sus salidas de información expresadas en esquemas, narrativas, metáforas verbales y visuales, imágenes y otros datos de significancia que posibiliten dar cuenta del vínculo y coherencia entre su intencionalidad, interpretación, conceptualización y figuración de la estructura formal para el automóvil. 


\subsection{Diseño de la Estética del Objeto con Enfoque Pragmático}

Bajo el enfoque pragmático del estudio de caso, se trata de un pensamiento en acción que produce un conocimiento derivado de su propia experiencia y de su construcción autorreferente. En línea conceptual con Dewey: la experiencia (acto de diseño) está constituida por la interacción del diseñador con su medio para conocer nuevas direcciones y explorar nuevas posibilidades que pueden estar incluso, dentro de sí mismo. En su pragmatismo, el pensamiento es una construcción mental y sensible que guía la práctica y que a la vez se transforma con la acumulación de la práctica para tornarse conocimiento, un conocimiento que puede ser tácito porque se adquiere de forma inconsciente pero que otorga una habilidad proyectual de combinar mente y sensibilidad, intelectualidad y acción mientras se crean las condiciones para sus efectos inmateriales y materiales. Para el diseñador comporta poner en juego su imaginación mientras conserva una conciencia de su propia historicidad y realidad sociocultural en la que opera como también una disposición de interacción con otros para resolver problemas o anticipar situaciones deseables. En tanto construcción única su experiencia es autorreferente, posee rasgos específicos de estructura y funcionamiento con su complejidad.

Con su sentido de pensamiento funcional bajo la forma de que un problema se resuelve progresivamente en un momento histórico caracterizado por la aceleración de transformaciones económicas, tecnológicas y sociales, determinadas desde el Estado y las instituciones; el accionar se torna condicionado por la finalidad.

\subsection{Acto de Diseño: Relacional y Performativo}

Como rasgos de operación relacional identificamos:

1. El sentido de la estética del objeto es el diálogo con el sujeto desde su sensibilidad e imaginación más que con el entendimiento. Un juego donde la imagen del objeto (expresión performativa) activa el interés y la libertad del receptor para encontrar una forma de representación que armoniza consigo mismo.

2. El pensar - actuar del diseño para la estética del objeto comporta un intercambio entre el diseñador y el contexto en el que ejecuta un encuadre de la realidad, el cual alimentará su producción imaginativa y faculta una expresión performativa que posee valores compartidos con los individuos. Esto implica para el diseñador, articular lo sociológico-discursivo (identificación de sujeto con discurso ideológico y convenciones sociales), lo referencial-expresivo (referentes y representaciones que modelan fantasías y preferencias) y la experiencia estética (interacción placentera - subjetiva del sujeto con el objeto para otorgarle su propio sentido).

3. El diseño para la estética del objeto implica encadenamientos de significado de la información obtenida que le lleven del 'caos a la unidad' de sentido estético. Una confrontación de sistema de referencias y la construcción de nuevas o fusionadas. 
4. La forma como estructura sinérgica de contenidos es una trama de relación de interdependencia de elementos que poseen una esencia individual pero que conectan como unidad armónica.

Como operación performativa identificamos estas características:

1. Acto de expresión de lenguaje que en sus narrativas: verbal y visual, posibilita la comunicación con lo simbólico y lo metafórico. Ese sentido expresado como narrativa en cada Concept car puede interpretarse como una historia que habla de una imagen autorreferente idealizada y sensible del sujeto proyectada en el contexto a través del objeto.

2. Es autorreferente al tratarse de un acto único ejecutado en circunstancias particulares, que constituye su propio carácter y estructura de concepciones como una nueva realidad. Y es, a la vez, referente porque se corresponde a una estructura normada socialmente que le otorga sentido y le avala.

3. Transitando de las ideas a la acción de concretarlas produce efectos inmateriales y materiales. Para el caso del diseño, produce expresiones enunciativas y provocadoras para la experiencia subjetiva y sensible que se vehiculizan en la imagen del objeto.

4. Tratándose de un acto de creación que no es totalmente libre ejerce la autonomía para la construcción de su ficción y valor identitario.

\subsubsection{Operaciones relacionales}

Lo relacional está asociado al vínculo, a la búsqueda de correspondencias o modos de asociación que facultan conocer, comprender y dar sentido a algo. Estas operaciones habilitan al diseñador para alcanzar la sinergia interna de su estructura formal mientras conecta con el contexto y su propia intencionalidad de producir un mensaje con resonancia emocional para otros y para sí mismo, llamado estética del objeto.

En la práctica pragmática de los diseñadores Concept cars, una trama entre datos de la ideología, de sus imaginarios y simbolismos, de ideas precedentes, patrones, valoraciones de la realidad presente y otras de ficción van articulándose para constituir algo que no es del todo original pero que en línea con lo kitsch, es disruptivo, una nueva narrativa con deslizamiento de otros referentes pero con el potenciamiento de su mensaje en la profusión de su ornamento que no es sólo físico sino mental.

\subsubsection{Esquematismo}

Con la formación del pensamiento estético encontramos que el intercambio del diseñador con el campo le aporta información tanto conceptual como de cualidades sensibles que circulan en la estructura social que las adopta, avala y disfruta. Esa esencia relacional para la construcción mental, imaginativa del sentido estético para la forma de los Concept cars, demanda habilidades innatas del individuo que combinan sensibilidad, imaginación y entendimiento. Condiciones fundamentales para la experiencia de conocimiento humano y

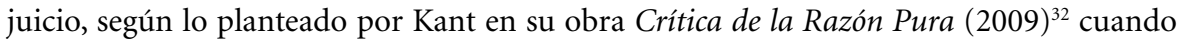
presenta el esquematismo como una experiencia de intersección de las cualidades sensibles y el concepto de los objetos de la realidad, es decir que las apariencias sensoriales, físicas y 
mentales que son captadas por la sensibilidad pueden llevarse a una matriz sintetizadora de datos organizados en categorías como unidades de sentido comprensibles o conceptos. "Que hay dos ramas del conocimiento humano, que quizá se originen en una raíz común, pero desconocida para nosotros, y son a saber, la sensibilidad y el entendimiento. Por medio de la primera, nos son dados los objetos; por medio de la segunda los objetos son pensados" (p. 2).

El par sensibilidad - entendimiento es fundamental e inseparable dado que a través de la primera captamos los objetos en sus representaciones e intuiciones ${ }^{33}$, pero es por el entendimiento que pueden ser pensados como conceptos. Captar la multiplicidad de representaciones de la realidad presente implica que esa diversidad sensible, (su esencia y no sólo la forma de ellas), se someta a un juicio de discriminación - asociación para que luego, se agrupe homogéneamente para producir un significado. En ese proceso entra en juego la subjetividad del diseñador quien además pone en tensión algunas relaciones del sujeto con las representaciones y conceptos que allí encuentra.

Siendo el esquematismo una operación cognitiva que faculta la intersección de las cualidades sensibles y los conceptos de los objetos de la realidad, produce una matriz de datos que facilita la comprensión del sentido estético del campo, aporta conocimiento para la posterior construcción imaginativa de nuevas configuraciones que, en todo caso, puedan conectar con el contexto espacio temporal de donde emergen. Kant afirma que el gusto opera como un mecanismo de vinculación de apariencias y conceptos entre lo que se presenta al sujeto y lo que éste ha incorporado intersubjetivamente. A la matriz de síntesis de categorías, conceptos y sus cualidades la llama esquema; en tanto esquema mental tiene una utilidad reflexiva más que de determinación de juicios; posibilita hacer conexiones de ideas, imágenes y combinaciones como preconceptos, que en palabras kantianas equivalen a ideas estéticas.

\subsection{Concepto}

Vinculado a la idea es una construcción mental formada por la noción de algo que posee características que pueden expresarse lingüísticamente. Un concepto es también la anticipación de unas cualidades que aún no existen y que pueden posibilitar una experiencia. Ubicado en el plano del entendimiento, el concepto es una unidad de compresión que faculta conexiones con las intuiciones captadas por la sensibilidad y que luego, alimentan el juicio.

\subsection{Cualidad sensible}

La cualidad sensible reúne varias acepciones:

1. Una propiedad del objeto empírico que estimula los sentidos para captar la atención del sujeto, por ej.: volumen, línea, color, textura o proporción.

2. Una característica cualitativa atribuida en la adjetivación y que puede tener valor simbólico para la estimulación de la imaginación, la memoria y conectar emocionalmente; por ejemplo: 'aquella nave dorada que vuela pegada al suelo y que con su cuerpo estilizado alcanza velocidad supersónica para tocar la luna'.

3. Un atributo de relevancia en el juicio estético, normado por patrones de preferencia. 
Es por el entusiasmo del diseñador que el ojo y la fantasía captan lo no dicho. La observación es una operación de ver para entender, actúa como base de la receptividad en el esquematismo. El equipo GM denomina granitos de oro a esas representaciones del medio que son captadas y que aportan al diseñador un entendimiento de lo que es el automóvil no como un mero utilitario, también como parte de un gran sistema de movilidad y de interacción social; un medio de expresión de libertad, de sensualidad, de proyección individual y colectiva. Es decir que no se trata de una mirada de catalogación literal de los modelos que circulan como representación pictórica sino que se trata de ver detrás de la forma, aquellos símbolos que sean significativos para la conexión con las personas y su entorno.

\subsection{Categoría}

Interpretada como la herramienta principal que utiliza el entendimiento para conectar información abstracta y concreta de la realidad sensible y de conceptos ligados a los objetos, es también un recurso de agrupación de características homogéneas de un fenómeno. Constituyen abstracciones de las representaciones particulares en la intuición y se relacionan con objetos a priori; es decir que no requieren un conocimiento pleno desde la lógica si no que, su aprehensión se posibilita desde un carácter universal y el conocimiento interno del individuo. Pero también, pueden aplicarse como un sentido lógico que guía la discriminación de rasgos típicos que identifican el fenómeno en observación para una agrupación homogénea. La categoría es formal y determina la estructura, mientras que la intuición da el contenido (material empírico) que debe ser organizado.

Con las categorías es posible organizar las percepciones estableciendo enlaces a través de conceptos a priori y del material empírico. El diseñador interpreta de esa pluralidad de representaciones externas y de las intuiciones sensibles, cualidades a través de los cuales organiza su experiencia, sin que ello suponga que alcance un conocimiento pleno de ellas. De ese grado de incertidumbre, surge la indeterminabilidad y la incidentalidad de su propuesta, de otra manera se caería en la mera reproducción de la realidad objetiva sin ningún grado de sorpresa y novedad. La arbitrariedad que pueda ser apreciada como inadecuación a lo hegemónico, otorga también un grado de libertad para la interpretación. Por otro lado el diseño industrial opera bajo la presión de estandarización y la homogenización del gusto en la expansión de oferta y de patrones de consumo y recurre a la imitación (del latín imitatio) como copia parcial de referentes previos, aunque no pertenezcan a la misma categoría funcional del objeto, como repetibilidad de patrones acertados para facilitar el reconocimiento de elementos familiares de figuración, de significados y de estilo 'un conjunto coherente de formas unidas por una conveniencia recíproca, pero cuya armonía se busca, se hace y se deshace con diversidad'. Asociada a un acto de duplicación, la imitación es considerada un objeto cultural, es decir, una unidad que porta valores que se reproducen por su significancia (Breyer, 2007).

En las relaciones: sujeto - campo, objeto - campo y sujeto - objeto, presentes en la realidad de la experiencia estética subyacen una serie de fricciones y antagonismos como nociones referenciales, motivaciones, significaciones, deseos dichos y no dichos que, al ser identificados por el diseñador, le orientan para la construcción de la dimensión semántica de la forma, una vez se reflexionen tres puntos: 
1. Una conciencia ética frente a lo abstraído, (aunque sea impregnada de una interpretación subjetiva), para la elaboración de un medio de expresión de valores que, al corresponderse, inciden en las relaciones sociales.

2. El compromiso de congruencia entre lo comprendido de la realidad y lo que se va a componer como respuesta deseable y de transformación con valores de sorpresa y novedad. 3. La validez de una adecuada interpretación se hará manifiesta en la adecuación que los argumentos construidos tengan para los diferentes actores en una realidad socio cultural y espacio temporal localizada (Krippendorff, 1987).

Con aplicación del esquematismo interpretado en la praxis de los diseñadores GM de los Concept cars, se obtienen tres categorías:

1. Sociológico - discursiva: que asimila la relación del sujeto con el pensamiento de la época (espacio-tiempo). Observa en la ideología, la trama de significados y valores que conforman: la imagen, el juicio del gusto y medios de relación de las personas en el contexto espacio temporal.

Y para el diseño (encarnando la problemática del objeto) su relación con los contextos formativos de sus paradigmas y de su intencionalidad estética, permite comprender cómo lo visual debe tener coincidencia con su construcción conceptual.

2. Referencial - expresiva: Observa referentes de la cultura material como codificación y expresión de representación - presentación. Se alude con representación a la designación de elementos de naturaleza metafórica que tienen intensidad evocadora desde su presentación y que se contienen desde su construcción conceptual (adjetivaciones, contenidos significantes y simbólicos). Mientras que la imagen de presentación, (el objeto visual figurativo), procura mantener presente la atención a la naturaleza del artefacto con sus cualidades (línea, contorno, textura, color, brillo) y promover las asociaciones de sentido y de sentimientos. Según Seel (2010), un objeto presente en el mundo siempre refiere a algo; su superficie es un medio de diálogo y una fuente de correspondencias a partir de sus atributos apreciables ya sea en proporción concisa, de saturación, de semejanza. La imagen como sistema y unidad de carácter sensible permite en su aparecer, apreciar su valor de fantasía.

3. Experiencial - estética, orientada a la interacción sujeto - forma del objeto, involucra leyes de experiencia estética para la estimulación visual, la interpretación de su mensaje y la respuesta emocional. Para el acto creativo se enfoca en: 1. Apariencia del objeto. 2. Aparecer del objeto. Esquematizar tanto los contenidos del mensaje: metáforas como significado simbólico y otras propiedades que captan la atención para la conexión sujeto con la superficie envolvente del automóvil. Para el aparecer, el conjunto de estímulos de la puesta de escena del objeto incluyendo el lenguaje verbal y corporal de quienes presentan y representan cada modelo, la marca e ideología.

De las tensiones presentes en las diferentes relaciones sujeto - objeto - contexto el diseñador obtiene pares polares y posibles significados operacionales ${ }^{34}$ : proyección, armonía, 
expresión, contraste, diferenciación, autonomía, sorpresa, fantasía, identificación y convergencia, los cuales pueden llevarse a la composición semántica como anticipación de las cualidades del carácter estético.

Los pares polares más significativos encontrados son: 1 . sujeto - objeto, el sujeto se proyecta a través del objeto, a su vez el objeto es una proyección de la imagen del sujeto. 2 . Entre entendimiento - sensibilidad se procura una armonía para la percepción e invención de la realidad. 3. Entre lo instituido - aspiracional se busca una expresión de adecuación y alcance de lo que no se tiene. 4. Las personas aprecian el contraste que emerge entre lo normado y la novedad. 5. Individual - colectivo genera un deseo de diferenciación, con ello se logra un valor de singularidad. 6. Entre lo objetivo y lo subjetivo se busca un grado de autonomía entre el juicio y la sensibilidad. 7. Entre lo real y lo ficticio, la expectativa es la sorpresa, aquello que responda a motivaciones tácitas. 8. De lo determinado e indeterminado, circula la fantasía y se fomenta el interés. 9. De presentación - representación, fácil asociación al concepto y estímulo de la imaginación para completar el mensaje. 10. Del caos - unidad entre lo inconexo, sin orden a una armonía atrayente.

\subsubsection{Esquema}

Al que identificaremos como matriz estructural que posee sus propias reglas sinérgicas y contiene una red de conceptos organizados como construcción de sentido interno a partir de la imaginación, pero significativos por medio de la experiencia y el conocimiento ya adquirido. Es un instrumento de socialización de ideas: mapa, boceto, red de relaciones o figuraciones es, además, una forma de hacer explícito el pensamiento estético del diseñador, veamos algunos postulados:

En el sentido kantiano el esquema es producto de la imaginación que alude a la determinación del sentido interno en general; una idea que en conformidad con el espacio y el tiempo que se produce, puede ser comprendida.

El término esquema ha sido vinculado al diseño de diferentes maneras; como dibujo para la expresión de una idea, como concepto, como ruta de acción; ligado a la percepción se entiende como instrumento de diálogo entre creativos y otros actores desde sus autoconceptos. En palabras de Jones: un metalenguaje para describir la "relación entre estrategia y situación de diseño" (Jones, 1980, p. 55). "Los diseñadores están destinados a tratar como real lo que existe sólo en un futuro imaginado y deben especificar formas en que se puede hacer que lo previsto exista" (Jones, 1980, p. 10). Un compromiso de predicción implícito supone un alto compromiso con un alto grado de riesgo o margen de error.

El esquema es algo análogo a la metáfora y otras figuras del lenguaje. Su uso intencional procura el agrado de correspondencia y afinidad de un individuo con la imagen representada. La imagen como recurso de comunicación del esquema se convierte en el punto de contacto entre las personas y los prejuicios de éstas.

Con el esquema, el conocimiento subjetivo que los diseñadores adquieren en su intercambio con el material empírico del campo se vuelve explícito y por lo tanto sujeto a la interpretación para su transferencia o evolución. En la tabla 3 presentamos la matriz de síntesis del esquematismo. Ahora en el (esquema 2), exponemos la deconstrucción de esta operación: 


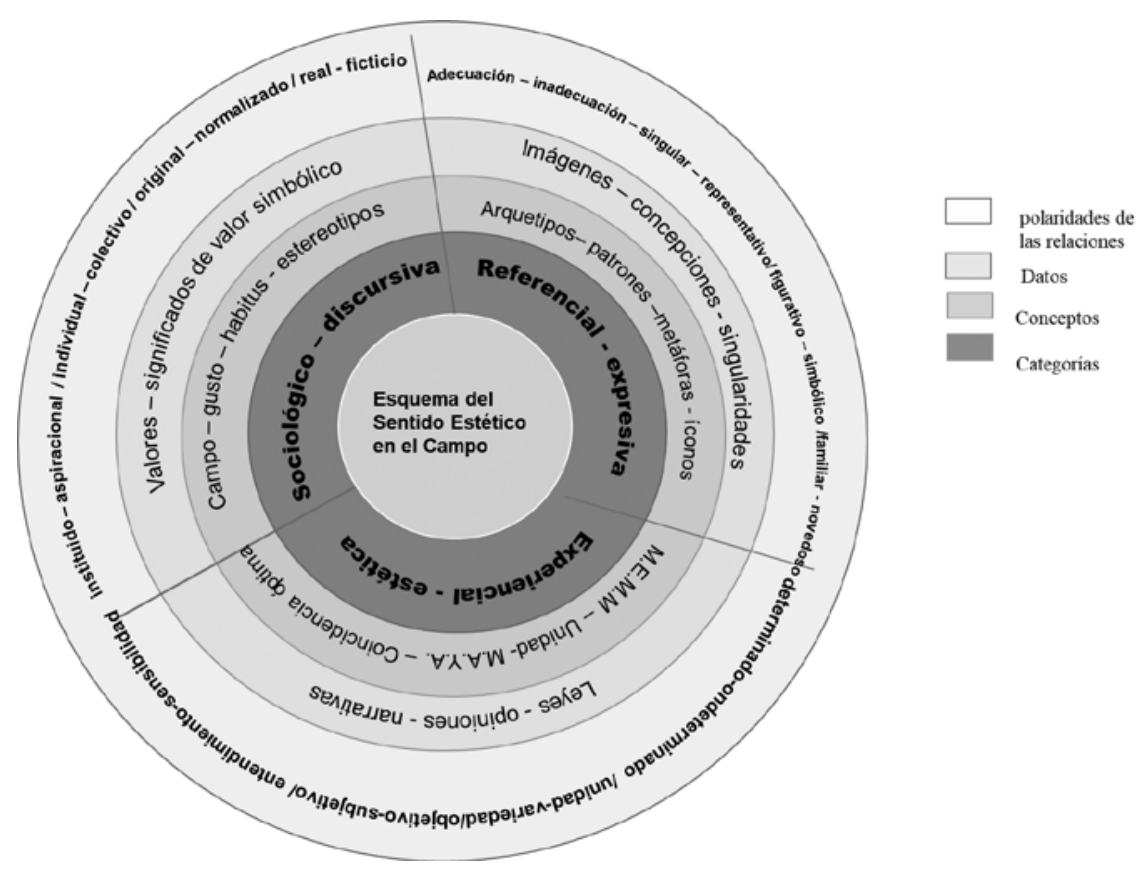

Esquema 2. Categorías y Conceptos del Sentido Estético del Campo. Fuente: elaboración propia.

Recorriendo de adentro hacia afuera se identifican las tres categorías que empaquetan los conceptos que proveen datos con cualidades particulares y significativas de los discursos sociales, los referentes materiales y principios de experiencia estética para llegar a unas polaridades estructurantes de las relaciones que se manifiestan entre el sujeto con el campo, el objeto con el campo y el sujeto con el objeto, los cuales se convierten en significados operacionales para la posterior conceptualización y figuración de la forma total con sentido estético. De ese esquema como matriz estructural que posee sus propias reglas sinérgicas y contiene una red de conceptos organizados como construcción de sentido interno, el diseñador obtiene una sistemática para la observación y registro de datos del campo, la ejecución de sus propias conexiones de las manifestaciones materiales y los conceptos encontrados que luego se unen a fundamentos de composición figurativa.

Avanzando en la sistemática, se expone en este (esquema 3) los grupos compositivos de la forma total identificados: 


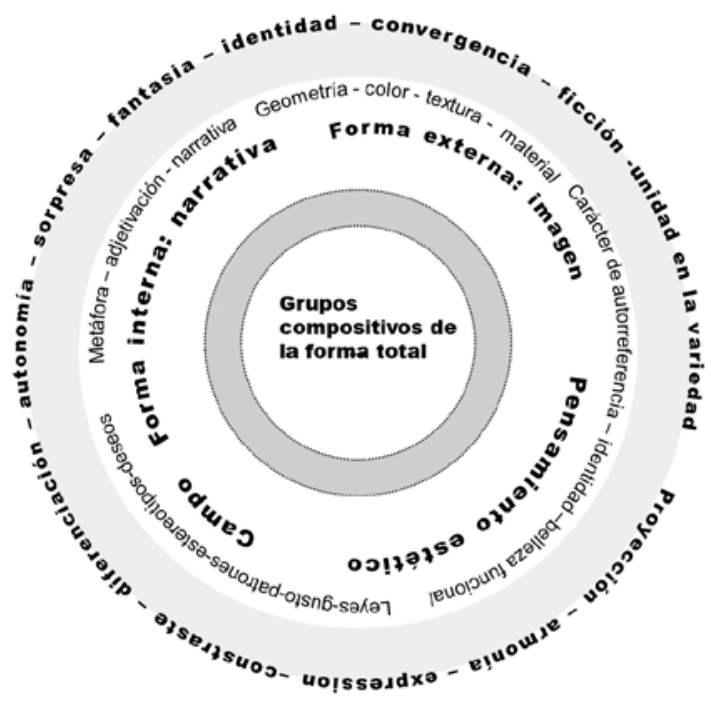

Esquema 3. Grupos Compositivos de la Forma Total. Fuente: elaboración propia.

Del centro hacia afuera: pensamiento estético (construcción mental para pensar el objeto estético), campo (contenidos de cualidad sensible y conceptual de la realidad como base para la adecuación y conexión), forma interna (composición performativa del mensaje de las cualidades de la imagen externa y condiciones dialógicas con el sujeto) y forma externa (conjunto de cualidades sensibles para la imagen de la superficie material del objeto). Juntos conforman una estructura sinérgica que se va construyendo relacional y performativamente, (esquema 4):

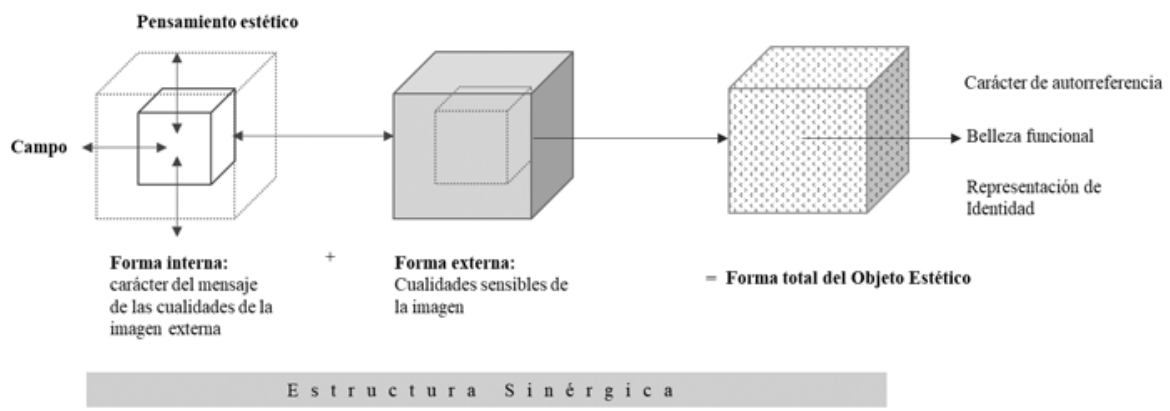

Esquema 4. Forma Total. Elaboración propia. 


\subsection{Diseñador}

El sentido estético de la forma comporta para el diseñador la reflexión de que es por un lado estructurado: amoldado por las circunstancias, el tiempo, sus campos de existencia y sus experiencias. Por otro, estructurante de nuevos conceptos, materializaciones y experiencias mientras viaja en una dinámica que mueve valores de apreciación de los fenómenos y el modo en que los individuos se ven a sí mismos. Se trata esencialmente de seres humanos que se enfrentan a la incertidumbre, descomponen el problema del diseño, generan las mejores alternativas posibles y encuentran un diseño satisfactorio, en tanto hay una especie de concordancia entre las propiedades internas y el entorno externo del artefacto artificial, ya que constituye un componente básico en la creación humana y la interferencia con el mundo (Herbert, 1996).

El diseñador como unidad intersubjetiva que intenta una producción objetiva; mira hacia afuera y dentro de sí, no escapa a la realidad social para representar valores de identidad y que se fusionen con su construcción creativa para ofrecer nuevas estructuras conceptuales y representaciones que conecten con las personas. Su acto creativo se nutre de la socialización de ideas, la producción narrativa que anticipa las cualidades de la forma y que recibe la devolución de otros para su refinamiento. Con foco en la creación estética su imaginación puede realizar la operación de vincular la materia sensual con el significado conceptual en una construcción abierta. Por lo tanto, la cognición puede implicar una búsqueda abierta de conceptos para adaptarse a una apariencia dada. Esto conlleva la generación de múltiples ideas y propuestas que requieren un enfoque y desenfoque para evaluar su coherencia interna y adecuación con la estructura dada en la conceptualización. Para Earl, el equipo de diseñadores debe tener un valor común: 'Tener combustible en sus venas' (they have gas in their blood) compartir la pasión por los automóviles y la potencia para ir hacia adelante, mientras se aporta una dosis personal.

Con diferentes perfiles de edades, géneros, formación empírica, formal, técnicos, artistas, se pueden sortear la complejidad y multidimensionalidad del diseño. Un ejemplo de ello es Carl Renner incorporado en 1945 después de trabajar por un año en Walt Disney Studios, desarrolla el Nomad car (1954), el Corvair y el Cadillac Cyclone (1955 a 1959), para el 1956 el XP-100 de 1956 Concept car que evoluciona al Corvette Impala.

En su naturaleza relacional y de socialización en el trabajo, los diseñadores establecen lo que llamarían los bocetos empáticos (empathic sketches), los cuales contienen descripciones de adjetivación y visualización de formas posibles, son utilizados para comunicar la esencia de la idea y de su definición como figura. La importancia dada a este medio de expresión en su acepción de empatía es justo captar la reacción de colegas frente al mensaje emocional producido. James señala que dándole una relación significativa al trazo y el efecto deseado encontraron un indicador de calidad a su capacidad de comunicar en unos y visualizar en otros las cualidades particulares y el carácter que intentaban otorgar a sus modelos. 


\subsubsection{Habilidades del Diseñador}

Hay cuatro habilidades proyectuales del diseñador para su pensar - hacer- sentir en el acto creativo: interpretación, reflexividad, agencia e imaginación.

\subsubsection{Interpretación}

Con esta habilidad cognitiva cada sujeto tiene la oportunidad de apropiar sentido y construir uno diferente dentro de los marcos de referencia universales e histórica y socialmente construidos, como también a aquellos que conciernen a una realidad interna del individuo. El principal desafío que el diseñador asume como intérprete es comprender aquellas narrativas, explícitas y otras tácitas presentes en la sociedad y la cultura, para luego reflexionarlas como significados, usos y conexiones afectivas con las personas en el marco de su experiencia estética sin menosprecio de la multiplicidad de factores (manufactura, usabilidad, desempeño técnico-funcional, ecológico, entre otros) que comporta la forma del objeto industrial y que no nos ocupan en este estudio.

Como experiencia de diálogo con sus contenidos, resulta conveniente distinguir sociedad y cultura. Entendemos sociedad como el grupo humano que habita un mismo territorio físico que comparte una misma identidad e ideología, prácticas sociales y materiales que producen cultura (Bourdieu, 2013). Definimos la cultura como un sistema de creencias, valores, costumbres, comportamientos y artefactos compartidos que los miembros de un grupo cultural utilizan para hacer frente a su mundo, a otros individuos y que se transmiten a través del aprendizaje (En Crouch y Pearce, 2013: Bates y Plog, 1976). En común, sociedad y cultura son fenómenos dinámicos en el tiempo que dejan rastros cuya comprensión total, no es posible siempre.

Acudiremos a algunos planteos de la Hermenéutica como la doctrina de la interpretación para describir a qué refiere esta habilidad y cómo es incorporada por el diseñador a su práctica. Hans Gadamer (1998a), sitúa la interpretación junto a la comprensión, el lenguaje, la tradición y el diálogo como expresiones de interacción humana y con el mundo. La historicidad representa una condición positiva de la verdad. La tradición como algo que se ha consagrado en el pasado posee una autoridad anónima que se incorpora no sólo en el razonamiento sino en la acción y el comportamiento y que en todo caso requiere un acontecimiento reflexivo. "la inevitable y necesaria distancia de los tiempos, las culturas, las clases sociales y las razas o las personas es un momento supra subjetivo que da tensión y vida a la comprensión" (1998a, p. 110). Comprender significa aquí reconocer y hacer valer. El sujeto intérprete pone en juego sus propios supuestos y hace un aporte productivo, sin desconocer, que el lenguaje como medio de interacción humana, posee códigos como significados que son reconocidos y validados colectivamente. Su punto es que el sentido, como comprensión de la intención de una expresión, difiere al significado como código. En su intercambio el diseñador conforma su propio esquema a través del cual construye su pensamiento y estructura su experiencia creativa.

En un ciclo que nunca acaba, ni en el que todo puede entenderse, a lo que puede aspirarse es a una serie de síntesis coherentes para el intérprete. La tensión se presenta cuando el diseñador construido socio históricamente y con una experiencia de aprendizaje singular, hace una lectura no neutra en la que intenta razonar objetivamente desde su subjetividad. $\mathrm{Al}$ respecto, Gadamer considera que "el intérprete y el texto tienen su propio horizonte" 
(1998a, p. 111) y que la comprensión supone una fusión entre esos dos horizontes; una lectura objetiva de los significados y una subjetiva que otorga sentido a lo observado y al prejuicio con que observa el individuo. El sentido no reside en la información sino en el sujeto quien la otorga con su comprensión; sin menosprecio del lenguaje que expresa la proyección de la multiplicidad de aspectos que constituyen su representación y que pretenden ser una unidad comprensible.

Entonces la comprensión, se trata de un acto recursivo de deconstrucción y construcción de la realidad, que requiere la identificación de unidades clave y un posterior ensamblaje coherente con atribución de una cierta autonomía del diseñador, aunque esté inmerso en interacciones colectivas y de la tradición. Con el esquematismo observamos cómo se manifiestan estos atributos de la interpretación, un esfuerzo de receptividad sensible y del entendimiento de representaciones y manifestaciones materiales, conceptos que se mueven al interior de las relaciones que el sujeto tiene con el contexto y con los objetos para que el diseñador llene los espacios de esa narrativa social y cultural que es multirreferencial. Con la interpretación vista como una habilidad cognitiva que comporta imaginación, la construcción de ficción es posible, así que el diseñador produce su propio esquema siempre y cuando prevalezcan valores posibles de asociación con la equivalencia de imágenes y conceptos a ser expresados. Como acción comunicativa y estética la interpretación es vista como un "proceso de traducción en que se transforma algo en otra cosa" (Iser, 2005, p. 29). Acorde con Iser, la estética es un movimiento de la polaridad sujeto - objeto, se posa en el medio para desatar un acto interpretativo; el sujeto llena los espacios que el mensaje genera con intención de una lectura para la construcción de sentido. Allí se da un proceso reflexivo que, además, acude a la memoria, para integrar el pasado o la experiencia previa al presente con las proyecciones de expectativas creador - receptor y proyectarlas a través de mensajes verbales visuales. La imaginación tiene el potencial de transformar el material que podría recibir de la experiencia, y a través de la "negación de la condición de estar en el mundo" ofrecer nuevas condiciones de significación, aquellas que de seguro pasaron por una lluvia de ideas y así de vagas líneas a la composición detallada. De ideas gruesas o difusas, farragosas a una esquematización estructurada (En Folkman, 2013, p. 71: Sartre 1940, p. 261).

"El relato rehace al mundo de la acción. No se trata pues de negar el carácter subjetivo de la comprensión en la cual se consuma la explicación” (Ricoeur, 1999, p. 87). En el mismo sentido de la narrativa, el relato constituye una comunidad y por la cual ésta se interpreta, las historias que circulan ofrecen un medio de interpretación y comprensión de los valores, como fue mencionado en el capítulo de formación del pensamiento estético. La comprensión que Earl y su equipo alcanzan de su entorno en los 50s y 60s con acontecimientos disruptivos como adelantos tecnológicos: la fiebre por la conquista del espacio planetario e interplanetario, el inicio de la televisión a color, el rock and roll como exploración de expresiones artísticas con sensualidad y persuasión e interacción colectiva, enriquecieron su narrativa metafórica, de ficción y de novedad. Los avances aeroespaciales de Estados Unidos de los 50's, la euforia por la conquista del espacio y la proyección de una hegemonía tecnológica, alimentan el orgullo y la confianza americanos, así como el pensamiento estético GM para los Concept cars. 


\subsubsection{Reflexividad}

Es la capacidad que tienen los individuos para intercambiar la información que compone la realidad de la sociedad y la cultura en orden de deconstruirla para construir su propia identidad, voz y valores (Bourdieu, 1984). Con ella acude a la razón, los sentidos y la sensibilidad; por tanto, es vista como un proceso que habilita al individuo para identificar su relación subjetiva con la realidad objetiva desde su experiencia personal. En el proceso reflexivo un individuo comprende quién es y cómo lo externo le constituye (Giddens, 1991). El diseñador como miembro de la sociedad y responsable del diseño estético, enfrenta la dicotomía: autonomía - subordinación. La ideología conforma la estructura hegemónica del pensamiento y los valores que constituyen al individuo sin mayor oportunidad de autonomía (Žižek, 2001); con una visión más liberadora, Giddens y Bourdieu, consideran que la reflexividad dota al individuo de una habilidad de negociación, para conciliar el hecho de que una construcción es relativa al marco sociohistórico que la produce condicionado al individuo y su historia personal le dota de una conciencia que guía su construcción e intervención sensible.

\subsubsection{Agencia}

El diseñador como actor clave del acto de creación asume una posición con base en su saber y experiencia proyectual y en lo que se denomina su campo intelectual ${ }^{35}$; un sistema de relaciones sociales y culturales que restringen y condicionan al sujeto encargado de la creación.

En el marco de la Psicología, la agencia de un individuo se entiende como la habilidad de concebir acciones consciente e intencionalmente, en la que la subjetividad del individuo que intenta actuar objetivamente otorga un modo particular de pensar y actuar. La reflexividad soporta la agencia, la cual se mueve entre un cierto grado de autonomía y otro de adecuación a modos de proceder instruidos en los que opera; un sujeto reflexivo intercambia con la estructura social, que es hegemónica sobre el individuo, pero logra una posición para decidir y actuar; un bajo grado de reflexividad le lleva a subsumirse en lo determinado para conectar con la estructura social (En Crouch y Pearce, 2013; Giddens y Bourdieu, p. 21). Con esta habilidad de agencia el diseñador asume un pensar en acción con autonomía cognitiva sobre los problemas a resolver, las soluciones posibles, su socialización de ideas y una sucesión progresiva de operaciones para procesar de manera estructurada factores de diversa naturaleza y traducirlos en expresión estética.

En su enfoque pragmático, la acción es la fuente de la reflexión, la incertidumbre e indeterminabilidad de lo que se inicia hace surgir lo diferente gracias al agenciamiento del diseñador en sus operaciones relacionales y performativas en las que se nutre en el juego de intercambio y su participación interna con relación a la realidad y de las condiciones de su experiencia.

\subsubsection{Imaginación}

Para el equipo de diseñadores, la imaginación es una actividad cognitiva que se produce en el intercambio de imágenes externas e internas para la producción de otras nuevas. Para que se dé esta actividad, los individuos requerimos de percepción de objetos físicos, representaciones y patrones, como también de la capacidad e intención de codificarlos. 
Los diseñadores son sujetos de mentes elásticas que toman la realidad para llevarlas a otros niveles de expresión ${ }^{36}$.

El diseño de la estética del Concept car desarrolla una figuración imaginativa de impacto masivo, social para su disfrute; una de las frases performativas de Earl en la praxis GM: 'la belleza ofrece más satisfacción y con ella más felicidad'. Lo nuevo versus lo viejo. Evitaremos a aquellos que nos digan que no es posible porque estaremos haciéndolo posible. Nuevas perspectivas alimentan la imaginación, la imaginación crea una nueva expresión de belleza para la vida cotidiana y su forma de experimentarla con el auto. El desarrollo de nuevos conceptos, sin embargo, requieren de la imaginación y el conocimiento teórico y de la sociedad ${ }^{37}$.

De esta visión conviene ahondar en la imaginación como herramienta proyectual, para lo cual coincido con Castoriadis (1999) cuando plantea:

1. El concepto de imaginación como origen de significado creativo a nivel social y colectivo; el diseño está allí inscrito como intervención social, influenciando la formación del gusto y mediando la experiencia estética. La imaginación hace una interpretación sensible de esas formas del material empírico que además constituyen unidades lógicas y de objetivos institucionales.

2. Lo imaginario puede ser radical en el sentido de que propone nuevos conceptos sin que ello suponga ausencia de otros precedentes; se desarrollan en un contexto y un modo de ser del momento sociohistórico. Por lo tanto, están sujetas a restricciones. Aunque el diseñador actúa como un promotor de formación del gusto depende del juicio de las personas en su apreciación.

3. Castoriadis ve el objeto como una entidad intermediaria en el cruce del mundo físico y el mundo interior de la mente imaginativa. Y ¿Qué es el objeto? el término objeto aparece como el fin del proceso proyectual, como el producto de unos conceptos estructurados con intencionalidad de organizar una materia dándole apariencia para su utilidad y disfrute estético.

4. Lo que comienza como una imaginación inmaterialmente operativa se materializa mientras permanece impregnada de significado imaginario. Los Concept cars son una expresión de belleza funcional que contiene valores de identidad, tecnológicos, de cociente estético.

5. La imaginación es un poder formativo para la creación de significado, la imaginación existe antes de nuestras categorías de significado y crea significado por nosotros y para nosotros: 'esta imaginación está ante la distinción entre lo real y lo ficticio' que opera en todas las personas, así que el diseñador se mueve en la dicotomía de originalidad - familiaridad, para lo cual debe enfrentar no sólo la distancia entre lo conocido que forma una preferencia y en aquello que de manera tácita se desea aunque no se tenga una imagen de lo que la cosa sea; el diseñador como encargado de anticipar esa creación de significado en una apariencia atractiva, se enfrenta al horizonte de expectativas del que habla Jauss y no sólo con respecto a su audiencia, sino a la coherencia y adecuación que alcance entre lo conceptualizado y lo figurado.

6. Existen cuatro tipos de limitaciones, que la psique humana se impone a sí misma cuando entra en un "tiempo y un mundo público" (p. 150): las limitaciones históricas de las 
instituciones y el significado en relación con el pasado y la tradición; y las restricciones intrínsecas de las significaciones imaginarias sociales de ser coherentes y completas. Como limitación intrínseca del proceso de diseño está la producción de una unidad de síntesis entre conceptos intelectuales y la multiplicidad sensible del entorno que incide en el entendimiento y la sensibilidad de las personas, cuando se reconoce la imposibilidad de conocer, por parte de los diseñadores, todas las representaciones que las conforman. La imaginación es la herramienta reflexiva que exploramos para considerar y descartar en múltiples ideas la posibilidad de una solución de diseño. Por la imaginación, podemos visualizar componentes del futuro y prever sus consecuencias particulares en nuestra existencia.

\subsection{Diseño Conceptual}

Con la presentación de Earl (1957) llamada Yo Sueño Automóviles (I dream Automobiles) Earl el líder del primer departamento de Arte y Color o de Diseño establecerá el diseño conceptual (Conceptual Design) como una fase estratégica.

Consiste en principio en una proyección imaginativa de producción retórica para la construcción del sentido estético del mensaje a ser expresadas en las cualidades de la superficie material o imagen externa del objeto, suma bagaje, intelecto, fantasía y emoción es un primer impulso de garabateo creativo, de lluvia de ideas que cubran un amplio espectro de posibilidades en el que intención - casualidad, precisión - caos están presentes.

La importancia de esto radica en que antes de obtener un concepto final, es preciso transitar por la integración - discriminación de ideas que van 'tomando forma' tanto como narrativa y como composición figurativa que física y emocionalmente corresponden a la búsqueda antes que la concentración en el detalle de la apariencia es provocar el acto de fantasía. Esta operación relacional - performativa supone por momentos, perder el rumbo, combinar conceptos que como trazos algunos son firmes, otros vagos, pero que en últimas ofrecen un marco de composición para ir en un movimiento que no es circular, porque el círculo solo tiene un centro, y una única mirada, foco o posibilidad puede comprometer su resultado. Ese movimiento es para los diseñadores GM, más bien elíptico en el sentido de que hay dos centros: por ejemplo: receptor y diseñador deben ser conmovidos, ingeniero y diseñador deben encontrar acuerdos y coincidencias para su concreción, correspondencia entre la narrativa y su esquematización figurativa; con dos centros o pares polares, el proceso de intercambio reduce la incertidumbre y nos acerca a la armonía. Un ciclo iterativo en el que se aceptan ideas, trazos consistentes, pero no definitivos para poder mejorarlos.

Con soñar, el líder de diseño alude a que encargarse de otorgar un carácter estético a cada Concept car, expresión de belleza funcional, identidad, autorreferencia, implica más que una labor cosmética como pudo ser percibida por sus compañeros de ingeniería que llaman a la división Salón de Belleza (Beauty Parlor); la forma del cuerpo del automóvil implica una estructura sinérgica interna y unas cualidades para la superficie material que deben conectar social y emocionalmente con las personas. Paradójicamente son muchas horas sin sueño que se requieren para avanzar en un espacio de trabajo colaborativo que jalona la construcción de nuevos conceptos, experiencias y desafíos que deben mantenerse 
en secreto incluso al interior de la General Motors, así que ventanas negras, puertas con acceso restringido componen el bunker del diseño.

\subsubsection{Construcción de Sentido Estético en el Diseño Conceptual}

Hablar de sentido, precisa la distinción de diferentes acepciones: lo experimentado a través de los sentidos, de la experiencia de sentimiento como conexión afectiva, de otorgar un valor particular a un fenómeno percibido; también puede verse como la razón de ser algo, la construcción de una narrativa para mover la sensibilidad y comprensión de otros y que se sostiene en imágenes mentales, arquetipos, metáforas y otros recursos de juego entre realidad y ficción.

Para Krippendorff (2006) el sentido puede verse como un modo de sincronización entre lo percibido del mundo exterior (representaciones u otros medios de estimulación de todos los sentidos) y la comprensión apoyada en conceptos o patrones que el individuo incorpora, resultando en una sensación de placer o displacer. Sí bien el sentido parte de un marco de significancia retórica en el lenguaje, envuelve una condición fenoménica de sensibilidad y no sólo de comprensión. "Sentido es el sentimiento de estar en contacto con el mundo sin reflexión, interpretación o explicación” (p. 50). El sentido implica otorgar una valoración personal que está condicionada por modelamientos particulares enraizados en el lenguaje, aprendizajes y memorias que habilitan formas de apreciación.

Buchanan y Margolin (1995) exponen que el diseño moderno con los diferentes paradigmas de la forma no constituye una ruptura radical con el pasado respecto del valor simbólico del objeto para la mediación de la experiencia estética. El foco ha incrementado en los factores sociales y culturales, los cuales otorgan sentido al objeto por su contenido de significado, símbolos y composición plástica, en retorno nutrirse de los valores del contexto para su composición estética.

Con Bourdieu (2013) el sentido se aproxima más a los principios a los que acudimos para guiar nuestras acciones, nuestros juicios del mundo y de los otros, los cuales dependen del capital simbólico, intelectual y material que poseen los actores. Con relación a la práctica estética de las personas ofrece un marco para conocer la experiencia y el conjunto de reglas que norman determinadas preferencias.

Para este trabajo, el sentido estético del diseño formal está asociado a la esencia de la creación del objeto estético, a una estructura de correlación entre lo que toma de sus raíces y las señales que emite en nuevas direcciones para una percepción cercana y fascinante. El sentido está conectado con la intersubjetividad del individuo y su voluntad para captar no sólo la forma visible y palpable, sino también su contenido latente e invisible, ello implica poner en juego los sentidos, la sensibilidad y el entendimiento. Con los dos primeros hay una estimulación que remite a las emociones, a lo afectivo, con el segundo, un reconocimiento de patrones, representaciones, arquetipos asimilados para su identificación y proyección, incluso de sí mismos. En esa línea, acuden procesos conscientes e inconscientes y pensamiento subjetivo y objetivo como recursos de la interacción sujeto - objeto creado.

En tanto razón de ser, el propósito del sentido estético es avivar la fuerza expresiva de la forma narrativa que ofrezca un sentido de interacción humana placentera con el objeto como su medio de expresión. El diseño reconoce al sujeto de interacción como un ser 
apto para comprender y dotado de una sensibilidad y voluntad para captar al objeto y a sí mismo. Las infinitas posibilidades de la imaginación, soportada en la razón y en la atenta observación producen ideas estéticas, una nueva construcción que fusiona imaginarios previos y produce un excedente de significado.

Desde lo performativo para los diseñadores GM, la belleza significa una expresión autorreferente, novedosa y sorprendente de algo que funciona y que representa una imagen idealizada, compartida y avalada socialmente tanto para el automóvil como para los individuos. Es decir que, en su comprensión del contexto, del sujeto y otros objetos, encuentran que es bello algo que no sólo es captado en las cualidades visibles e invisibles de la forma a través de su apariencia, también porque esta le permite al sujeto proyectar una imagen de cómo quiere verse y cómo quiere ser visto a través de ese objeto estético: automóvil. También contemplan un sentido objetivista de la belleza como composición que se rige por leyes de percepción humana, por lo tanto: unidad, armonía, balance, unidad en la diferencia, congruencia, avanzado pero aceptable, novedad y familiaridad son fundamento de la figuración.

Con una perspectiva compatible, Gillo Dorfles en su libro El diseño industrial y su estética (1968) expone que el "diseño industrial como una disciplina en desarrollo (...) íntimamente vinculada a la elevación física y mental del nivel de vida, el desarrollo y el acceso a una existencia más humanizada" (p. 5), genera una especie de forma artística, la cual contiene sorpresa y novedad (sin esta no captura atención y pierde valor estético) rasgos aspiracionales y adecuados al fenómeno del gusto, alcanzando una esteticidad, que comporta una dimensión de significado antropológico. En su pensamiento estético toma fundamentos de Kant para plantear que el objeto industrial es un binomio de belleza utilidad, la belleza adherente como representación agradable de lo bueno en consideración a la finalidad objetiva o concepto funcional del objeto, se distingue de una belleza pura de la naturaleza en la que nada falta ni nada es superfluo, a lo que se aspira es a un cociente estético; una cantidad de valores simbólico y expresivo porque además el objeto es un "mensaje" con coeficiente informativo (p.41).

La belleza del objeto reúne un conjunto de atributos de la forma externa, como representación de su utilidad o de la categoría sensorial a la que pertenece, y una belleza interna la cual puede interpretarse como su mensaje y las cualidades que potencia a través de la fuerza expresiva del material, de leyes compositivas para la percepción, de los símbolos que circulan en la sociedad, deseos y gusto como del mensaje propio del diseñador que procura el agrado o placer en la apariencia que este determina.

Como salida de la operación imaginativa, de producción de información se obtiene la síntesis de la totalidad de los grupos compositivos de la forma total como estructura de sinergia interna para la imagen externa atractiva coherente entre su pensar y actuar estético. Earl promueve la experimentación de conceptos y figuraciones nuevas para producir placer, e indica que esta es una forma de investigación pura durante el avance del diseño, siempre que se conserve el valor de identidad y se construya un carácter singular.

El poder del diseño como configurador de imaginarios, su naturaleza competitiva y de influencia social, entre otros roles, le permite hablar de un lenguaje estético propio. "En el nuevo arte ya no es la belleza la máxima regidora, sino la efectividad en la transmisión de un mensaje o de un sentimiento" (Morcillo, 2013, p. 24). Para Earl el Diseño y belleza no 
sólo comandan la atención, son la base fundante del vivir ${ }^{38}$ a lo que Nuccio Bertone agrega "Un automóvil es el producto de un sentimiento, o más bien, una serie de sentimientos". Así, el resultado, el objeto estético, es una mediación de experiencia sensual un significado que excede la razón y la expresión humana porque es la producción de un significado intersubjetivo en tanto su conexión sensorial y su capacidad emancipadora de imaginación y emoción. "El sentido se puede percibir, aunque no sea intencional" (Ricoeur, 1977, p. 234). Del sentido percibido y sus reacciones, Earl y su equipo obtienen la retroalimentación que completa los vacíos y no equivalencias que su conceptualización y figuración aún no alcanzan. Ahora, se precisa anticipar el medio de expresión (mensaje metafórico y un alto grado de fricción ${ }^{39}$ en los detalles), el mensaje y las condiciones dialógicas para su audiencia, con dosis de entretenimiento, el objetivo es mover las emociones de las personas.

Como aparecer del objeto estético, la feria itinerante Motorama, muestra la articulación de lo que para Gadamer (1998b) son tres necesidades humanas básicas:

1. Juego como componente lúdico, describe un movimiento entre el sujeto (sensible y apto para comprender) frente a la vitalidad del mensaje estético del automóvil que se torna una conexión intrasubjetiva y de autorrepresentación del individuo. El auto de sueño en su sentido estético más que un medio es una mediación, una interfaz estética además entretenida.

2. Símbolo, del latín simbŏlum como representación de una cosa se asocia con la necesidad humana de proyectar una imagen idealizada que aspira a completar el ser, correspondiéndose con su entorno mientras marca una singularidad; por ejemplo: El nombre del Pontiac Club De Mere proviene de uno de los clubes sociales de más alto nivel socioeconómico y con ello un mensaje de estatus social para quien lo posea.

Precisamos reflexionar acerca de que prácticamente es imposible para el diseñador conocer todos los símbolos que circulan socialmente, de lo que se trata es de enfocar adecuadamente el problema de la estética del objeto y volver a la realidad presente para captar de ella lo que es significativo a la intencionalidad del diseñador, una alta complejidad que se une a la de anticipar las reacciones emocionales sin que surjan respuestas no previstas o incidentales.

3. La fiesta como forma alegre de interacción humana, un encuentro alegre con el otro. Motorama es un espacio creado intencionalmente para el disfrute y la libre expresión de las personas, una condición activa, hiper estimulada por la circulación de información real y ficticia entre sujeto - objeto.

\subsubsection{Dimensión Semántica del Diseño Conceptual}

El diseño conceptual se asienta en operaciones retóricas que, como recursos performativos no sólo se aplican a los Concept cars sino a la internalización del pensamiento estético GM.

Algunos ejemplos de narrativa se enuncian a continuación:

Earl en 1958: Apariencia y función son de importancia equivalente. Ahora el diseño empodera el mundo de los negocios y las ventas. Esta frase marca un vínculo de importancia entre la estética del objeto y la dinámica del negocio en ventas. 
En la siguiente frase puede notarse el uso marcado de la adjetivación, la comparación, y la enunciación evocadora en su intención de distanciarse del paradigma caja sobre ruedas: Estos modelos, algunos eran realmente cercanos a la escala y proporción, no eran como los autos del momento, sino como podrían ser en el futuro. Fue realmente inquietante ver estos cuerpos redondeados en un período en el que los automóviles eran principalmente sólo cajas sobre ruedas.

O esta alusiva a las habilidades del diseñador:

Para poder contemplar la belleza se deben tener muy ejercitados: el ojo y la fantasía, lo que tiene carácter es atractivo.

Entendiendo la construcción semántica como la composición que otorga el sentido para la esencia o carácter de la estética del objeto, avanzaremos con las operaciones retóricas más recurrentes en la praxis de los diseñadores GM: narrativas, metáforas verbales y visuales y adjetivaciones.

Krippendorff y Butter (1984) en su trabajo Exploring the symbolic qualities of the form definen 'semántica de producto' como un campo de estudio de los contenidos simbólicos de significación cultural que aunados a la producción de significantes para las relaciones pragmáticas y la determinación de la apariencia visual otorgan al artefacto una doble naturaleza: subjetiva - objetiva destacando la naturaleza inmaterial del artefacto, aquella que es posible desde un proceso de conceptualización que mira a las estructuras sociales y culturales para comprender sus valores, demandas y no sólo sus significados. En el material, observa el conjunto de elementos compositivos en su aspecto configurativo y expresivo que pueden ser percibidos.

Establecidas las dimensiones inmaterial y material en la semántica del objeto, proponen tres modos de abordaje:

1. Lingüístico con foco en el significado de los conceptos, el lenguaje del objeto con relación al rol de aplicación del objeto en los contextos imaginables; el automóvil es medio de transporte, de carga o de refugio. El sentido entonces es la explicación de lo que algo hace en un contexto particular de la experiencia y la sensibilidad: cómo las personas apropian espontáneamente al objeto.

Se ha dicho que la estética otorga un valor relacional entre el sujeto y el objeto no sólo por sus propiedades perceptibles en la imagen externa, también por el mensaje que esta proyecta y no sólo acerca del automóvil, de la persona como actor social. Una mediación para que el individuo experimente su entorno y encuentre una identificación con la codificación estética que el diseñador ofrece como belleza funcional. El Concept car Corvette de 1961 constituye una expresión performativa que habla de la vida del sueño americano.

\subsubsection{Narrativas o historias}

¿Cómo utilizan las narrativas o las historias en el diseño conceptual? Se iniciará diciendo que las personas viven en una historia desde que nacen hasta que mueren. Las historias son metáforas de vida con inicio, desarrollo y final, al igual que los artefactos, permiten la adhesión de significados a través del tiempo y a partir de la experiencia. Las personas diseñan su mundo como historias y por ello su gran empatía por ellas (En Krippendorff, 2006: Larry R. Cochran, 1990). 
James Norman (2007) uno de los diseñadores del Firebird, recuerda que uno de sus maestros insistía en que las historias son una habilidad innata y común en todas las culturas, con lo cual, un recurso de conexión humana.

'Las historias son reflejo de cómo pensamos. Muestran cómo hacemos sentido a la vida. Llámelas esquemas, guiones, mapas cognitivos, modelos mentales, metáforas o narraciones. Las historias son cómo explicamos cómo funcionan las cosas, cómo tomamos decisiones, cómo persuadimos a los demás, cómo entendemos nuestro lugar en el mundo, creamos identidades y definimos y enseñamos valores sociales (Rutledge, 2011).

En el Laboratorio Experimental sobre Ruedas (Experimental Laboratory on Wheels) de la GM comparten la idea de que un diseñador industrial no diseña sólo en función de lo que las personas necesitan sino de lo que ellas desean, aunque no sean plenamente conscientes de ello o que lo expresen; en todo caso la expresión del diseñador es lo que otorga el carácter estético de la forma (James, 2007) ${ }^{40}$. Sloan en uno de los discursos de Motorama en Nueva York en 1954 menciono que para el equipo de diseño de los Concept cars, el estilo es entendido como una determinada forma de resolver los desafíos estéticos de la forma otorgando un carácter singular y que produzca una expresión distintiva.

Para la praxis en cuestión, las narrativas son descripciones orales o escritas de una anticipación de cualidades y modos de experiencia con los Concept cars. Lo más relevante no es su manejo como figura literaria, sino la expresión de sus representaciones o imágenes mentales que resulte emocionalmente eficiente. Así que uno de sus recursos más notables es la metáfora, así como el uso de adjetivos. También combinan significados referenciales y no referenciales. Con los primeros, se ofrece una cierta certeza y fácil comprensión del carácter otorgado a la forma, con los segundos, se prevé una cierta indeterminabilidad que estimula la curiosidad por sus rasgos internos y externos de la apariencia. No se trata de una expresión especulativa en el sentido desconocer su intención o fundamentos, tampoco de un libre ejercicio porque tiene un marco que procura la conjunción de descriptores para la expresión de una unidad armónica.

Una de las cualidades que procuran establecer es la identidad: entendida como un conjunto de atributos que distingue una entidad, está implicada en el contexto geográfico, sociológico, cultural, ideológico en el que se origina. Con la identidad se proyecta una imagen que puede ser física y mental con mensaje de significado simbólico y valor sensible. Diferentes niveles de identidad entran: identidad americana, identidad General Motors, Concept cars, modelo específico, conductor de perfil específico, clase social, género, son algunas de sus expresiones.

La identidad es otorgada en el diseño a través de proposiciones y descriptores que ubican jerárquicamente una serie de atributos los cuales, las personas asocian con su significación social y que para efectos prácticos ejerce un rol de diferenciación y no sólo de identificación (Krippendorff, 2006). Thorstein Veblen (1931) aporta la noción de conspicuos consumption (consumo conspicuo) para señalar que la decisión de adquisición de artefactos materiales de la gente excede sus consideraciones racionales en función de lo utilitario y se desplaza hacia un modo de prestigio social y de pertenencia a determinados grupos según 
sus prácticas de consumo, un modo de Dime que posees y te diré quién eres. Los diseñadores requieren conocer las diferentes expresiones de identidad implicadas en el diseño de un producto, la imagen idealizada que las personas tienen y también las instituciones.

La identidad tiene para el diseño formal otra implicación que la experiencia fue mostrando a los diseñadores: el lenguaje visual de marca, el cual es entendido como un conjunto de cualidades sensibles: líneas, figuras, volúmenes, escala, proporción, color, textura, que en tanto sistema visual otorga identidad a las diferentes series: Buick, Cadillac, Corvette son algunas de ellas. Sí bien excede el alcance del presente estudio, la identidad como lenguaje visual de la marca y como descripción verbal es un aspecto estratégico que trasciende a la identificación del sujeto con su propia identidad.

En síntesis, las narrativas como recurso de producción del mensaje no emergen de la nada o de una actuación caprichosa, como se ha venido caracterizando, se trata de una composición que se nutre del intercambio permanente y de la proyección imaginativa de los diseñadores. Pensamiento estético, Campo, Forma Interna y Forma Externa como fundamentaciones conceptuales con contenidos dinámicos se entrecruzan en la trama narrativa.

\subsubsection{Adjetivación}

El carácter resulta de todas las construcciones adjetivas que una comunidad de partes interesadas en el automóvil considere adecuadas, para el caso: belleza - funcional, la simbiosis tecnológica y estética que debe una coherencia con su finalidad funcional y se mensaje expresivo. Como recurso de comunicación directa, la adjetivación puede ser un poco ambigua sí se tiene presente que en tanto significado tiene una equivalencia en las personas conforme a codificación del lenguaje o del sentido que se otorgue en contexto, como fue explicado anteriormente. Así por ejemplo más largos que anchos pueden ser interpretados como de apariencia más atractiva, pero también más aparatosos para conducir. Como herramientas de interpretación de sentimientos, opiniones y deseos, dispuestos en pares opuestos, resultan una herramienta de testeo tanto cualitativa como cuantitativa muy potente porque las personas asumen la necesidad de elegir entre un polo u otro clarificando preferencias que pudieron haber sido tácitas para ellos. Para los diseñadores son pistas claves porque pueden comprender dónde poner el énfasis de sus composiciones.

El equipo de diseño hace una correlación de los adjetivos como asignación de carácter a cada modelo, equiparándolo con la identidad de un individuo. Algunas de las asociaciones radican en que la identidad como conjunto de rasgos singulares que distinguen a una persona de otra, son además susceptibles de valoraciones por parte del colectivo con toda una gama de deslizamientos, su desafío es determinar lo que haga que la ilusión Algunas de sus aplicaciones:

1. Pares de adjetivos de propiedades: veloz - lento; largo - corto; frágil - robusto; ruidoso - apacible; brillante - opaco.

2. Pares de adjetivos de evaluación estética: bello - feo; balanceado - no balanceado; armonioso - discordante; elegante - gracioso; ingenioso - trivial.

3. Pares de adjetivos de posición social: clase alta - clase baja; costoso - barato; a la moda - fuera de moda; distinguido - popular; universal - individual. 
4. Pares de adjetivos relativos a respuesta emocional: excitante - aburrido; atractivo - repulsivo; inspirador - no inspirador; frustrante - satisfactorio; perturbador - motivante.

\subsubsection{Metáforas: Verbal y Visual}

Lakoff y Johnson (1987) definen las metáforas como innovaciones semánticas que hacen que veamos una cosa en términos de otra, inciden en la percepción como esquemas de abstracción porque poseen dominios de experiencias análogos y de fantasía, una estructura propia dada por el patrón de construcción; toma significados de otra cosa y los resignifica imaginativamente conservando rasgos del referente inicial para facilitar su asociación. Ej.: "Ese útil se llama automóvil, artefacto humano de hierro que quiere poner el cielo a los pies de su creador gracias a la ilusión de volar a ras de suelo" (Morcillo, 2013, p. 30).

La metáfora visual como representación simbólica, facilita la asociación inconsciente, reduciendo procesos cognitivos y facilitando los emotivos. Su inserción en el conjunto requiere una adecuación a toda la narrativa que se busca expresar con el modelo. Relativas al ciclo hermenéutico, las metáforas, portadoras de significado, pero con deslizamiento hacia la representación de otras cosas, o sentimientos, facilitan testear las reacciones espontáneas de los receptores y del grado de adecuación entre la intención del mensaje y lo captado.

Para el diseñador es un recurso de conexiones de imágenes, conceptos, relatos asimilados cuyas semejanzas le facultan para proponer una nueva estructura con poder evocador de valor simbólico. Con la metáfora (verbal y la visual) el creativo puede expresar una idea como figuración mental de un mensaje y o de un conjunto de cualidades que aún son rugosas o aún abstractas pero que con la metáfora otros pueden comprender por semejanzas con conceptos concretos. Por su poder evocador a través de su valor simbólico, permiten figuraciones y prefiguraciones, es decir la anticipación de un porvenir deseable. En el sentido estético los valores sensitivos y emocionales priman sobre la orientación racional y analítica reuniendo tres metáforas como recurso de construcción simbólica en el que puede combinar metáforas: 1 . De orden histórico que recuerda objetos previos 2 . De línea técnica que expresa los contenidos de ciencia y tecnología 3. La de analogía con seres de la naturaleza para deslizar patrones de escala y proporción, carácter o significado para las personas. 4. La transposición de conceptos, imágenes de otros contextos del conocimiento y la experiencia.

Desde el enfoque psicológico, Donald Norman en su libro Emotional Design (2004) plantea que las personas tienden a asociar emoción con belleza; nos gustan los objetos atractivos por lo que ellos nos hacen sentir; el sentido estético es atribuido por la persona al objeto cuando éste es capaz de evocar una asociación significativa y de sensación placentera de su apariencia. La estética del diseño es un modo de intervención social con efectos emocionales que pueden incrementar de manera significativa la calidad de vida de las personas. Una resonancia emocional desde la mirada psicológica o de energía psíquica por el intercambio simbólico que acentúa la identidad de la persona respecto de su contexto.

Norman sugiere que los estudios sobre la complejidad de la estructura del cerebro y las emociones de las personas encuentran tres niveles de respuesta: 1 . Nivel visceral asociada a la respuesta automática a estímulos, cualidades sensibles como el color son un recurso. La metáfora por su naturaleza simbólica de espontánea asociación a símbolos, imágenes 
previamente incorporadas, tiene una fuerte correlación con este nivel, no implica una elaboración compleja del pensamiento para su reconocimiento. 2. Nivel conductual controla el comportamiento: maneras de expresión y acción que el diseñador capta en el esquematismo de la realidad y en su evento Motorama permite transformar la experiencia de entretenimiento en un espacio que impulsa el deseo por el automóvil. 3. Nivel reflexivo: implica la contemplación y la elaboración de ideas que conectan con el simbolismo de los imaginarios personales y colectivos.

El equipo GM de diseñadores sabe desde el inicio cómo utilizar la metáfora: Auto Soñados (Dream Cars), Imaginación en Movimiento (Imagination in Motion), Laboratorio Experimental sobre Ruedas (Experimental Laboratory on Wheels) para mencionar algunas del marco de los Concept Cars. Como se mencionó antes un recurso retórico de enorme capacidad de conexión con las mentes y las emociones, dispone a las personas para la anticipación del futuro y las narrativas que cada modelo va a contar. Las personas deciden su compra por la preferencia estética, su conexión emocional más que por lo que conocen sobre el desempeño técnico de los objetos (Gartman, 1994; Norman, 2004; Desmet y Hekkert, 2002; Hekkert 2006).

James Norman diseñador GM para la serie Firebird exalta la importancia del uso de la metáfora por su poder evocador (a algo que existe) y de deslizamiento de la fantasía del espectador (a algo desconocido) e indica que en su experiencia, la interpretación hecha por los receptores de una propuesta estética sorprendía al propio diseñador, pues su idea se tornaba en una nueva combinación o significación emergente de lo captado y lo imaginado por el receptor, mostrando que en ocasiones se mejoraba su versión. A esa condición de favorable distorsión, la llamaron incidentalidad del diseño, argumentando que no es posible tener pleno control ni justificación del mensaje estético de la forma que en todo caso tiene una esencia abstracta.

Desde la perspectiva de producción de significado, Per Brandt en su trabajo Meaning Production, Modelling Architecture and Blending (2014) afirma que las operaciones retóricas tienen como propósito la empatía, eso implica la construcción de significado el cual posee una estructura conceptual interna, un mínimo de imágenes y un estado fenomenológico como escenario al que se puede hacer referencia en la situación actual del sujeto. En el diseño favorece un efecto performativo entre lo determinado - indeterminado; las metáforas, captan la atención y hacen que la mente tenga un significado abstracto, el grado de empatía que alcance estará ligado a los conceptos evocados en función de la experiencia social, la experiencia física y mental de su destino, pues su papel de conexión se centra más en el sentir e imaginar, (relacionados al tener y querer) que en los procesos lógicos y de carácter universal. Entonces, como objeto mental, la metáfora es un recurso que permite combinar imágenes de naturaleza diferente para mejorar la expresividad y la notoriedad de la intención en el mensaje. Vistas como imágenes mentales, relacionan la percepción y la creatividad.

En complemento al contenido metafórico de la forma, el color refuerza el valor simbólico en beneficio de su atractivo estético, especialmente para las mujeres. Con ello, el color es estratégico en el pensar y actuar de los diseñadores GM Concept cars al punto que cuentan con expertos en teoría del color que procura la mejor experiencia de percepción con relación a los planos de luz y a las posibilidades de tratamiento superficial y de cualidades 
materiales. En su proyecto cuentan con desarrollos de lacas acrílicas que intensifican los brillos, efectos metalizados, superficies más lisas.

Para la serie de los 50s, el metal en los Concept cars es el material principal del cuerpo; la conformación de planchas metálicas de variedades que van del acero, a piezas en aluminio y manganeso, con alto brillo y grano fino o superficies lisas procuran proyectar sofisticación, nivel tecnológico y una evocación de deseo en la experiencia táctil de las personas con diferentes secciones y componentes del automóvil. Con el vidrio curvado, se logran no sólo la representación de cabinas, cúpulas de aeronaves con evocación de aerodinamismo sino también de novedad y anticipación del futuro en la estética de los autos, así como mejores modos de experiencia con el paisaje. El plástico enriquece los detalles: luces y accesorios. Con la fibra de vidrio nuevas posibilidades, más compactas en las versiones deportivas se concretan; metáfora, belleza funcional, facilidad productiva y concreto cooperan.

\subsubsection{Otros Medios de Expresión del Diseño Conceptual}

Es por la expresión y socialización que ideas, conceptos y conocimiento se hacen explícitos; esquemas, bocetos y operaciones retóricas han sido hasta acá exploradas. En este apartado se ilustrará el uso de diferentes tipos de modelos, relevando uno que fue implementado por la praxis de los diseñadores y que prevalece hasta hoy: el modelo en arcilla a escala real un recurso fundamental para transitar de ideas, volumetría, detalle a molduras de fabricación. También utilizaron extensivamente maquetas en madera de planos seriados para verificaciones estructurales, de dimensionamiento y proporción.

En una entrevista del año 1957, Earl dice que de un trozo de arcilla sacado del suelo se obtendría el auto deseado, para lograrlo se requeriría de una imaginación que adelantara el futuro con nuevas imágenes de los autos y añadió que, con los modelos, el trabajo cooperativo se enriqueció, y los malentendidos para explicar el porqué de no hacer más cajas con ruedas a los ingenieros se resolvieron de manera más divertida. A la pregunta: ¿por qué más largos y bajos? Responde: "debido a que mi sentido de la proporción me dice que los oblongos (más largo que ancho) son más atractivos que los cuadrados, una casa de rancho es más atractiva que una casa cuadrada, de tres pisos, o un galgo es más elegante que un buldog inglés". Afortunadamente, el auto comprado muestra que el público y yo estamos constantemente de acuerdo en esto (En The Saturday Evening Post, 1957, p. 2). Un buen número de practicantes y diseñadores formados en el Pratt Institute College of Design llegan a unirse al equipo GM, dentro de sus habilidades comunicativas están la creación de narrativas verbales y visuales, el estudio de dibujo 2D, 3D acompañado de leyes perceptuales, manejo de planos de luz, color, dibujo a mano alzada y también elaboración de maquetas.

\section{Conclusiones Parciales}

1. El acto de diseño para la estética del objeto se trata de un conjunto de operaciones relacionales y performativas que el diseñador desarrolla soportado en su pensamiento, 
intercambio con el contexto y sus habilidades proyectuales de observación, interpretación, imaginación, reflexividad y agencia.

2. Tratándose de una experiencia de corte pragmático, el diseño es un pensar en acción que produce conocimiento derivado de su experiencia en el intercambio con su entorno, así que evoluciona de la aprehensión de conocimientos previos, referentes para producir su propio sentido.

3. En su perspectiva estética se enfoca en lo relacional sujeto - objeto produciendo una serie de expresiones y medios performativos que dan lugar tanto al mensaje como a las condiciones dialógicas entre la información de la estructura interna e imagen externa del objeto y el bagaje de un receptor que es estimulado en su voluntad para apreciarla y expresar sus emociones.

4. Dos operaciones son fundamentales para el acto de diseño de la estética del objeto: el esquematismo y el diseño conceptual. Con el primero, el diseñador ve para conocer, asocia, discrimina, sintetiza y organiza una información que en principio es externa e inconexa pero que conecta con la que posee el diseñador, individuo socio históricamente construido e inmerso en el campo a esquematizar. Con el diseño conceptual, tanto carácter como anticipación de las cualidades de la superficie material o imagen externa del objeto pasan de esquematismos, ideas rugosas a una narrativa autorreferente, con fuerza evocadora posible de ser configurada en la forma.

5. El acto de diseño estético a partir de esas operaciones genera una estructura sinérgica de información que le da al diseñador argumentos del qué y cómo de su mensaje para la resonancia emocional con las personas. Pensamiento estético, campo, forma interna y forma externa en tanto grupos con su propia esencia y rol se interrelacionan para producir la forma total.

6. El diseñador en tanto sujeto intersubjetivo en procura de un resultado objetivo en el marco de un objeto industrial desarrolla habilidades proyectuales significativas que le dan un valor distintivo frente a otros colegas de diversas disciplinas. Con una profunda observación que pone en juego sensibilidad - entendimiento, datos externos - bagaje interno, discriminación - vínculo, homogenización - síntesis, aprehensión - proyección imaginativa, pensamiento abstracto - comunicación explícita avanza progresivamente.

7. El sentido estético del diseño formal está asociado a la esencia de la creación del objeto estético, a una estructura de correlación entre lo que toma de sus raíces y las señales que emite en nuevas direcciones para una percepción cercana y fascinante. El sentido está conectado con la intersubjetividad del individuo y su voluntad para captar no sólo la forma visible y palpable, sino también su contenido latente e invisible, ello implica poner en juego los sentidos, la sensibilidad y el entendimiento. Con los dos primeros hay una estimulación que remite a las emociones, a lo afectivo, con el segundo, un reconocimiento de patrones, representaciones, arquetipos asimilados para su identificación y proyección, incluso de sí mismos. En esa línea, acuden procesos conscientes e inconscientes y pensamiento subjetivo y objetivo como recursos de la interacción sujeto - objeto creado. 


\section{CAPÍTULO 4: CONCEPT CAR GM, OBJETO ESTÉTICO}

\section{Concept Car GM, Objeto Estético}

Preguntándose ¿Qué distingue al Concept car como objeto estético con relación a lo que expresa su imagen externa? Este capítulo denominado Concept car GM Objeto Estético tiene como hipótesis que lo que distingue al Concept car como objeto estético son sus cualidades de expresión autorreferente y referente en una apariencia que exhibe profusión en sus detalles, mensaje metafórico y de ficción en correspondencia con su concepción estética.

Y que la noción de belleza del Concept car puede describirse como una expresión armónica de cualidades propias de la categoría funcional del objeto y la representación de una imagen idealizada, compartida y avalada socialmente como apariencia atractiva.

El objeto estético es multidimensional:

1. Es el producto del pensar - actuar y la intencionalidad del diseño; la estructuración de una información diversa que se organiza como narrativa autorreferente con mensaje metafórico, valores de representación de identidad, mensaje de ficción y un conjunto de cualidades formales con sentido estético.

2. Como salida de las operaciones relacionales y performativas, se trata de una estructura sinérgica de contenidos de pensamiento estético, campo, forma interna (carácter del mensaje), forma externa bajo principios compositivos para la figuración de la materia con cualidades estéticas y un medio de expresión del diseñador para provocar una resonancia emocional en las personas. En el lenguaje GM: la yuxtaposición de los diferentes elementos compositivos, su disposición en una estructura que resulta en la apariencia final de belleza funcional ${ }^{41}$.

3. Como manifestación material una imagen autorreferente, valores de representación de identidad y de belleza funcional para la conexión con el sujeto.

\subsection{Objeto Estético: Concepción Multidimensional}

¿Cuál es la posición de los diseñadores GM de los Concept cars ante la creación, producción de un objeto complejo, multidimensional como el automóvil?

El diseñador GM Concept cars agencia múltiples factores asociados al sentido estético de la forma del objeto en un intercambio con su campo intelectual y de operación. Su implicación en la trama tecnológica, corporativa, social, cultural, histórica, personal implica para él (a) asumir una postura para alcanzar la autonomía del mensaje a expresar y lograr una percepción fascinante, atractiva y acorde a diferentes intereses y perspectivas.

Los requerimientos del estilo creativo automotriz son casi tan numerosos como exigentes. Un estilo automotriz verdaderamente exitoso, debe ser agradable para el creador, gratificante para el ingeniero e inspirador para su con- 
ductor, una belleza, practicidad y popularidad poco común y mágica ${ }^{42}$ (Harley Earl, 1954 Catálogo de Cadillac).

Con esta afirmación, Earl reconoce la complejidad del diseño estético en el ámbito del automóvil, los diferentes requisitos y niveles de apreciación para los diferentes roles de actores y la presencia de belleza, practicidad y popularidad en el sentido de la intención de masificación de este objeto en la sociedad.

1. Es el producto del pensar - actuar y la intencionalidad del diseño. En el recorrido de esta praxis de los diseñadores para la estética de los Concept cars GM en el período entre 1945 y 1965 hemos podido reconstruir un conocimiento tácito haciéndolo legible como características claves de su enfoque pragmático, una práctica intencional que avanza con la experiencia y el conocimiento adquirido por el intercambio de datos con la realidad presente, sus raíces, la proyección imaginativa y los resultados que producen. De su conocimiento tácito se infieren dos operaciones clave en el acto de diseño: esquematismo y diseño conceptual. Con el primero, la construcción mental, sensible relacional y performativa del pensamiento estético se va concretando en categorías para la producción de sentido, con conceptos traman una estructura sinérgica. Con el segundo, el diseño conceptual, la proyección imaginativa se asienta con operaciones retóricas que otorgan a la narrativa de cada Concept car un carácter único, de mensaje autónomo que mezcla ficción - realidad y que en todo caso atiende principios compositivos en función de la percepción sensorial -cognitiva y afectiva de las personas.

2. Como salida del acto de diseño, se obtuvo una estructura sinérgica de contenidos provistos que determinan las cualidades de la superficie material del objeto estético: Concept car. Para poder responder a la pregunta ¿cómo es la estructura sinérgica de la forma total con relación a la imagen del objeto estético Concept car? precisamos de la deconstrucción de sus contenidos y de la confrontación con la imagen externa del automóvil buscando la consistencia entre la intención - pensar-actuar - manifestación material, su adecuación y coherencia.

3. Como manifestación material, posee una imagen autorreferente, valores de representación de identidad y de belleza funcional para la conexión con el sujeto. ¿Qué expresa la imagen del cuerpo del Concept car que da cuenta de su carácter de autorreferencia, valor de representación y belleza funcional?

Para operacionalizar esta deconstrucción, acudimos a un análisis de comparaciones binarias $^{43}$ que permite cruzar en ambas vías cada uno de los grupos compositivos alternando su rol de entrada o condicionante y de receptor o condicionado. Por ejemplo: el campo en tanto entrada para la composición de la narrativa interna aporta representaciones de valores de la realidad presente y de raíces, preferencias de gusto al carácter del mensaje y su expresión. La narrativa interna como entrada al campo le impone una dosis de novedad y sorpresa que entra a jugar con lo normado por el campo. Es decir que en la estructuración 
hay una interacción en doble vía que enriquece tanto a la dimensión semántica como configurativa de la forma en función de la estética del objeto.

Tabla de cruce de grupos compositivos para la comparación binaria con relación a la imagen de diferentes Concept cars de la serie de estudio:

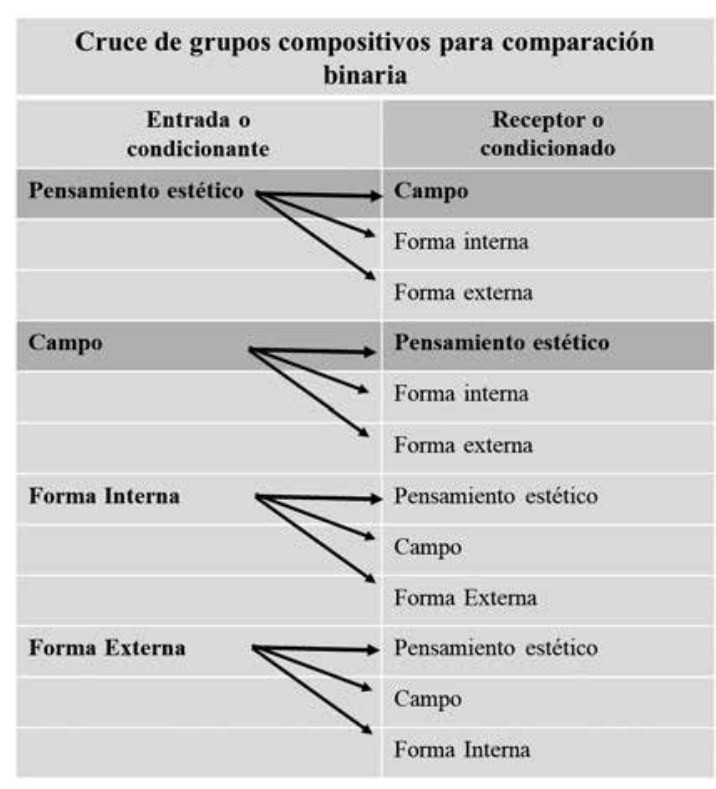

Tabla 1. Grupos Compositivos para Comparación Binaria. Fuente: elaboración propia.

\subsection{Forma: Estructura Sinérgica de Contenidos}

\subsubsection{Pensamiento Estético/Campo}

Los Concept cars o American Dream Cars son autos experimentales en la simbiosis estética y tecnológica. Con el pensamiento estético como entrada, éste propone al campo una representación futurista, de construcción única o autorreferente para la modificación de la escena social, la influencia en el gusto relevando el valor estético del utilitario automóvil, mientras se fusiona con los imaginarios de sueño americano, apetencia por lo material, lo agrandado, exuberante y de otros valores de avance social e individual. El pensamiento estético de GM expresa en 1950: "Para ser exitoso, el diseñador debe ir a la par con el progreso" ${ }^{44} \mathrm{y}$ en su praxis, un proyecto socialmente compartido y avalado. 
Una construcción mental que toma raíces socio históricas y produce señales que viajan en otras direcciones, las de una idealización que representa lo que esa sociedad quisiera ser, como quisiera verse, expresado en las cualidades de apariencia del automóvil, y las ideas e imaginarios que le soportan. Ejemplos de ello: Buick Le Sabre 1951, Centurión 1956 Cadillac El Dorado 1959, Corvette 1961. Buick Le Sabre que fue concebido en el marco del "laboratorio sobre ruedas" ${ }^{45}$ para testear ideas estéticas y mecánicas (tecnológicas), fue descrito por Earl (1950) "Este es el automóvil del futuro solo en el sentido de que algunos de sus diseños o características mecánicas pueden aparecer algún día en automóviles estándar" ${ }^{\prime 6}$. Su diseño es atribuido al equipo liderado por Harley Earl y Edward Glowacke bajo el proyecto Buick y el proyecto: Diseño de Automóviles Especiales (Special Automobile Design en inglés). El Segundo modelo de Concept car luego del Y-Job (1938): primer modelo de estilo estadounidense que se considera una expresión de sus ideas futuristas, de su aeroestética; belleza funcional apoyada en tecnología: vidrios eléctricos, techo corredizo, sillas con calefacción. Como muestra de interacción sujeto - objeto, el empoderamiento de la mujer para manejar un auto que aumenta sus proporciones: más largo que ancho, más bajo en procura de comunicar estabilidad, solidez y una reducción de peso con el uso del magnesio y el aluminio en su chasis.

Mensaje de distinción y lujo con los cromados, su apariencia tipo sport juega con contrastes de frente, lateral, trasero cuyas líneas y detalles tienen valor de representación de aeronave (Avión Sabre F-86). Una de las narrativas de este Concept car es: "Con la tecnología de propulsión a chorro cada vez más frecuente en la industria aeronáutica, Harley Earl se propuso crear un concepto que aplicó estos avances a un automóvil futurista”.

El pensamiento estético del diseño GM mueve los límites dados por los arquetipos del campo hacia expresiones de acento de identidad individual y colectiva con inclusión en la vida social. Con modelos 'pensados para las damas', se promueve el empoderamiento de la mujer en la conducción y tener interacción social con aires de seducción.

Dando un salto a 1963, el Concept car Corvair Super Spyder corresponde al proyecto liderado por Bill Mitchell en el marco del pensamiento estético Sports cars, que recoge el concepto Corvair (término que acuña Corvette y Bel Air) desarrollado en el Corvette entre 1952 y 1956. Con este relato: "Tú debes traer un auto en el que se pueda correr" ${ }^{47}$ se inició la serie. Su carácter es el de un auto deportivo compacto que muestra una nueva propuesta al campo: su escala y proporción se aleja del 'auto más largo que ancho' como el Buick Le Sabre o Cadillac Biarritz El Dorado, Cadillac De Ville, este mantiene lo glamoroso, aspiracional y orgánico en sus líneas. Con mensaje evocador del auto de carreras, su contexto de uso es la vida urbana; la metáfora de velocidad, estabilidad, competitividad es trasladada al imaginario de un conductor, quien suele ser un hombre protagonista y exitoso profesionalmente.

\subsubsection{Pensamiento Estético/Forma Externa}

El pensamiento GM adopta principios de leyes perceptuales para la composición geométrica de la forma, pero le otorga una fuerza expresiva de mensaje metafórico con conexión al campo y su narrativa de realidad - ficción, simbolismo y riqueza de detalles con contraste en partes, líneas, color y textura. 'El color debe hablar de una nueva era de vitalidad, 
progreso y sensualidad'. Sus concepciones se refinan con la experiencia y los resultados que concreta.

La abstracción de volumetría del referente, avión F 86 Sabre, es llevada al cuerpo del automóvil como se observa en el desfogue del avión que se lleva a la luz central hiperdimensionada del Concept car (figura 5 y figura 6):

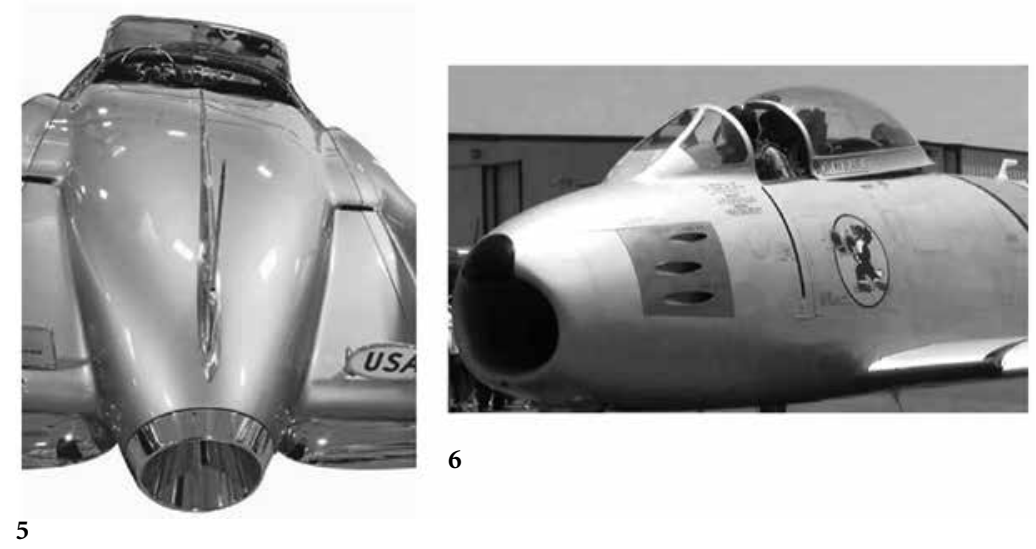

Figura 5. Foto del Concept Buick Le Sabre 1951 Sección Volumen Central Fuente: GM Heritage Center. Figura 6. Foto del F 86 Sabre Detalle Volumetría Cuerpo. Fuente: https://worldwarwings.com/original-f86-sabre-roars-loud-planes-fame/

Un detalle de belleza funcional como fusión de fuerza expresiva y utilidad, se presenta en la luz central delantera que cambia su apariencia cuando ésta se enciende y apaga. En su intencionalidad estética Earl relata "Buick Le Sabre un auto que en cuanto más se observa, más detalles se encuentran” (1951).

Para el Corvair Super Spyder, acorde a fuentes del Heritage Center de GM ${ }^{48}$, la alusión a spider (araña) y su inclusión de la y, como una forma de caracterización singular en el contexto de diseño, origina su concepto en la analogía que se hizo de la imagen de los carruajes como un cuerpo bastante símil al de la araña. Estos rasgos marcan para este auto su mensaje metafórico.

En la (figura 7-4) se aprecian los 'ojos de araña' en las luces delanteras del Corvair Super Spyder 1963 también detalles de los exostos y de la parrilla central con alusión al cuerpo de la araña y su red: 

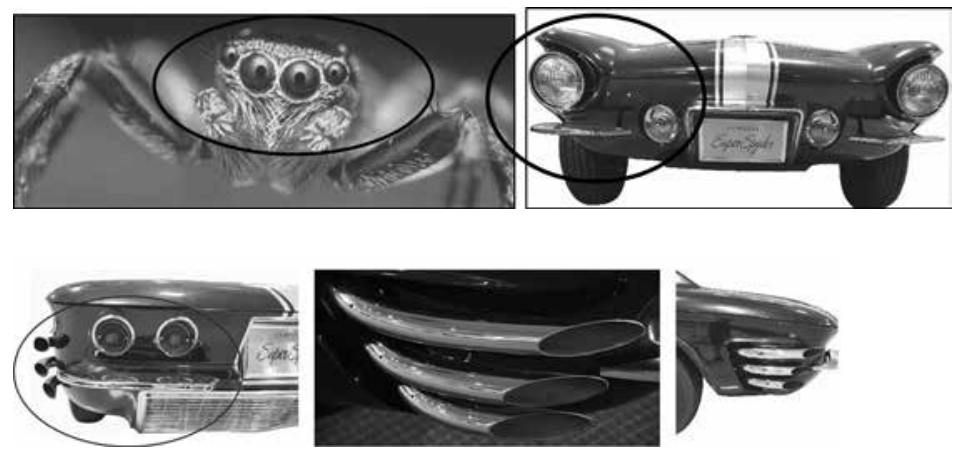

Figura 7. Foto Luces Delanteras y Detalles Exostos del Corvair Super Spyder 1963. Fuente: GM Heritage Center.

Para el modelo Super Spyder, la narrativa de la araña originada en la asociación del cuerpo de los carruajes se fusiona en el carácter deportivo del auto; la 'amenazante, enigmática apariencia de la araña' es acentuada en el uso del color negro del modelo; acorde a Joaquim Viñolas $^{49}$ (2005) el mensaje psicológico del color negro alude a efectos de misterio, sofisticación, e intimidación. Para el caso de este modelo, acordes a la intencionalidad del diseño estético de Mitchell como valor competitivo de los American Sports Cars.

\subsubsection{Pensamiento Estético/Forma interna}

El sentido estético del pensamiento GM es avivar la fuerza expresiva de la forma narrativa que ofrezca un sentido de interacción humana placentera y fascinante con el objeto como medio de expresión para lo cual, reconoce al sujeto de interacción como un ser apto para comprender, pleno de sensibilidad y con voluntad para percibir el mensaje expresado en la forma y su aparecer.

En la praxis analizada, se destaca el valor de la metáfora como recurso de producción de un marco que desplaza la representación de lo instituido en la realidad para la creación de una nueva, ya sea que exista en otros espacios de la experiencia humana o como anticipación de una que no existe. Como vehículo de fantasía es un recurso estratégico que hace del diseño estético una apuesta de innovación en las dimensiones inmaterial y material del objeto.

Otro elemento compositivo es la adjetivación que, está presente en las diferentes formas de comunicación. A nivel de socialización de ideas, presentación del concepto de modelo, comunicaciones escritas internas y con otros actores involucrados. Adjetivos como: único, futurista, bello, avanzado, estético, atractivo, empaquetan el conjunto de atributos que dan carácter y especificidad al modelo mencionado y a otros de la serie.

Le Sabre como metáfora del jet Sabre F-86, también alude a un nombre de origen francés, (asociado a un hombre distinguido, adinerado y rodeado de mujeres jóvenes y bellas), es 
un homenaje a la alianza con Francia durante la Segunda Guerra mundial. Adicionalmente como expresión gramatical alude al gusto francés por la sofisticación. Este auto invita a la libertad, a sentir el viento en la carretera, un aire deportivo, pero también de auto para ir de la oficina al club. Un modelo que antecede la producción de doce generaciones futuras como modelo comercial, para quienes buscan en el modelo anual, un nuevo detalle de belleza funcional. Su frente y cola procuran hablar del poder de una aeronave, es decir la posibilidad de "volar pegado al suelo" velocidad y poder, mientras se portan los cohetes, y una identidad nacional de orgullo estadounidense.

\subsubsection{Campo/Pensamiento Estético}

El campo como capital simbólico, de habitus, formación del gusto ofrece al diseñador la información que el lleva a un esquematismo de categorías y datos que al vincularse con el sentido estético de su pensar y actuar favorecen una conexión con las personas y los puntos de oportunidad para brindar novedad y sorpresa. Este intercambio de pensamiento y campo puede compararse con el horizonte de posibilidades de Jauss (1977) como una observación atenta a la interpretación y reacciones del lector frente al texto para que el escritor pueda lograr una creación para el deleite mutuo. Es decir que un diseñador inmerso en su realidad, viendo, comprendiendo la respuesta de su audiencia frente a referentes propios y ajenos, alimenta su proyección imaginativa y la probabilidad de una conexión positiva. El Buick Le Sabre es el auto personal del líder de diseño quien lo usa estratégicamente como interfaz para percibir directamente la reacción y retroalimentación del colectivo al que se proyectaron los diseños, a esta operación la llamó diseño empático, reconociendo el poder que representa la co-creación con las personas.

Con una profunda observación en otros campos de creación artística, el diseñador encontró valores de sentido estético, por ejemplo, en el del entretenimiento de Hollywood es uno de ellos. En tanto construcción fantasiosa alimenta el gusto por la ficción; las narrativas singulares en las que un cierto grado de indeterminabilidad, estimulan la imaginación para descubrir nuevas vías a las representaciones expresadas en la imagen y para su aparecer en el campo. Es e caso de una reconocida valla publicitaria en la que se enfatiza uno de los imaginarios instituidos (desde Estado y empresa): "El más alto estándar de vida del mundo" y "No hay otro camino que no sea el camino americano".

Artistas icónicos como Elvis Presley disfrutaban de la personalización de sus automóviles con la exageración de rasgos. Estos sujetos procuraron mostrar un carácter único, y con ello, fueron promotores de innovación estética en la apariencia exterior e interior de los autos y una inspiración para imitar para las personas del común. Otro modo de integración del automóvil al entretenimiento y las interacciones sociales es el cine al aire libre; familias, parejas y jóvenes asisten en 'su nave'.

El Cadillac Serie 75 Fleetwood de 1960 fue uno de los autos de Elvis al que solicitó un baño de oro para las tapas de rueda, los aros de las luces y la parrilla. Internamente se equipó con teléfono, frigo-bar, tocadiscos, televisor y cortinas con hilos de oro. La carrocería se pintó con 40 capas de pintura mezclada con perlas y polvo de diamante. Detalles de extravagancia como representación de la imagen de Elvis. 
El llamado "Rey del Rock and Roll", Elvis Presley fue amante no solo de la música y las mujeres, también de los automóviles especialmente los Cadillac, una de sus posesiones fue el modelo 1956 Elvis Rose, el cual ordenó personalizar: originalmente azul, pasó a rosa y blanco, su interior dotado con tapetes morados, tapicería bordada, con notas musicales, y guitarra a bordo, se exponen como una joya en el museo de Presley en Graceland, USA.

\subsubsection{Campo/Forma Externa}

Con el esquematismo del campo, el diseñador observa arquetipos, patrones, íconos, simbolismos que constituyen punto de referencia para su imitación, diferenciación o fusión con el carácter estético dado. Para la praxis en cuestión, lo hiperdimensionado, la saturación y extravagancia en ciertas expresiones y en la escena cotidiana muestran al diseñador señales de preferencia como pudiera observarse en los cafés-heladerías estadounidenses de los 50 s y 60 s como expresión de lo expuesto.

De tipologías naturales presentes en el campo, la silueta femenina y su naturaleza sensual son llevadas al Concept Buick del XP-300 1951 este diseño de Charles Chayne, su propuesta estética combina superficies curvas y lisas en el frente y lateral, en contraste con otras líneas rectas de alusión a solidez, fuerza y estabilidad de este modelo del grupo de los deportivos con sabor urbano. Un mensaje simbólico de tipo futurista en el trasero y otros del lenguaje deportivo en los laterales son rasgos distintivos de este modelo.

Como enlace a lo anterior, el edificio Chrysler construido en 1928-1930 por Walter Chrysler es una expresión del Art Déco en la arquitectura con importante presencia de metal y adornos. Una presencia imponente de expresión de determinación y de grito de independencia cuando este diseñador y hombre de negocios se retiró de GM para promover su propia marca Chrysler y dar origen a la serie Dodge. Un ejemplo de metáfora para este hombre tildado de ambicioso y arrogante que encargó hasta entonces, el edificio en ladrillos más alto del mundo, un monumento de sí mismo y un mensaje de un nuevo derrotero de altura en los negocios. En su estética, el edificio posee detalles que representan la edad de la máquina de la década de 1920 y con gárgolas y águilas que adornaron el edificio, metáforas de las tapas del radiador Chrysler 1929.

\subsubsection{Campo/Forma Interna}

Una nación victoriosa en período de segunda posguerra mundial, el sector del automóvil, el más fuerte medio de movilización de la economía. Ideología y valores alimentan la narrativa del diseño, y entre las dos, (realidad - ficción), un punto de intersección para la identificación, el contraste y el escape ${ }^{50}$ de la realidad en la que el colectivo de la clase trabajadora, especialmente, está inmerso. El automóvil mueve física y psíquicamente en correspondencia con los ideales y los aspiracionales de la sociedad, la nación y la marca. Campo y mensaje estético del objeto se mueven dentro de un sistema multidimensional: físico, mental y afectivo. El campo impone a la narrativa del automóvil un mensaje que represente sus valores y los exagere, de lo contrario se dificulta la asociación e identificación necesarias para una experiencia estética positiva. Jagtap y Jagtap (2015) hallaron que la forma de la superficie envolvente del automóvil tiene diferentes niveles de representación 
y una dualidad de ilusión - realidad, así cara, frente, lateral constituyen un mensaje y un estímulo visual.

En su praxis los diseñadores conservan los símbolos del campo y los desplazan con las metáforas verbales y las visuales presentes en la imagen para producir pulsos de ficción. En la misma línea Mohsen Jaafarnia (2019) en su investigación sobre la evolución del diseño del automóvil planteó que el diseño del automóvil ha sido impulsado por el intento de crear una expresión emocional de velocidad. Una clara muestra de ello, en el diseño estadounidense es la adopción de diseños de misiles de la década de 1950. Con el tiempo, los cambios en el estilo de vida y la cultura han alterado el significado semántico del marco de producción del mensaje. Como refuerzo a ello, la dimensión semántica del objeto se planta en la inclusión de valores relevantes de orden socio cultural (Krippendorff y Butter 1984 $)^{51}$. Que en la visión de Norman (2004) equivale a la correlación de campo y forma como una meta para lograr la emoción. El receptor en tanto sujeto socio históricamente construido percibe y aprehende el valor intrínseco del objeto, su sentido estético para atribuirle un valor emocional. La exhibición itinerante llamada Motorama trasciende el espacio de exhibición de los Concept cars y se convierte en un espacio de entretenimiento, interacción social y expresión de emociones desde los espectadores.

En la (figura 8) una pieza de Arthur Radebaugh ilustrador de Detroit orientado a la expresión del imaginario futurista del automóvil, autor de esta pieza publicada en mayo 4 de 1958 anuncia la proyección del vehículo de policía rodando en la ciudad de los supersónicos y al lado del Buick Centurión de 1956 manifiesta varios mensajes de valor simbólico: con la frase 'más cerca de lo que pensamos' un refuerzo al pragmatismo, a la creación de ficción que se incrusta en la mentalidad estadounidense donde 'las cosas son imposibles hasta que ya no lo son' y una afirmación del control y vigilancia desde lo institucional. Esta imagen representa otra evidencia de la conexión del campo y la proyección imaginativa de las narrativas de la forma interna:

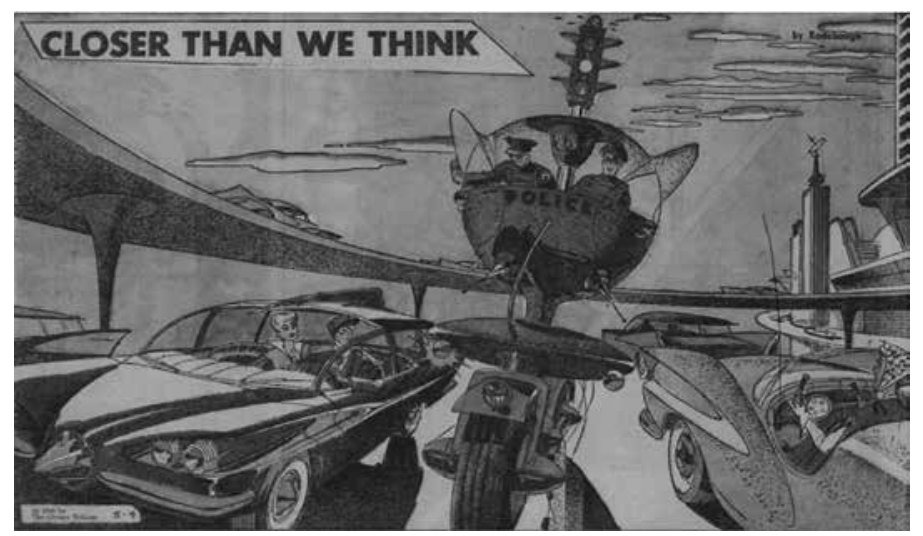

Figura 8. Foto de Ilustración de Arthur Radebaugh, mayo 4 de 1958. Fuente: https://paleofuture. gizmodo.com/ this-cop-car-ofthe-future-from1958-was-prettyintimid-1568730912 


\subsubsection{Forma Externa/Pensamiento Estético}

Este par remarca la importancia de los opuestos que se complementan cuando hay balance. Es la forma externa la manifestación visible y evocadora de la construcción de sentido estético dado en el pensamiento. Su composición está además condicionada al juicio del gusto como fenómeno social y a leyes perceptuales de orden universal, así que el pensamiento en tanto construcción única, autorreferente debe adecuarse a valores externos y dinámicos. Leyes como: unidad formal, familiaridad, novedad, diferenciación, detalle, continuidad de patrones típicos y cualidad superficial (textura) en armonía con la categoría de producto y también el reconocimiento de patrones y arquetipos fueron corroborados como bases de preferencia (Leder y otros, 2004; Hekkert, 2006; Jagtap y Jagtap 2015). 2. Empatía (identificación y conexión) por rasgos de identidad, representaciones de valor simbólico y rasgos que estimulen la fantasía (Krippendorf, 2006; Sudjic, 2009). Sí se tratará únicamente de una parametrización lógica de la geometría, el pensamiento en su valor subjetivo, social, sensible no tendría cabida para otorgar la fuerza expresiva de un mensaje a través de la forma externa.

El Concept Buick Le Sabre 1951 posee unidad formal, rasgos de familiaridad acorde con el arquetipo automóvil, novedad desde su expresión simbólica, diferenciación en escala y proporción 'más largo que ancho y más bajo', riqueza de detalle en frente, cola y superficie envolvente, cualidad superficial de alto lustre en armonía con la categoría de producto como aspiracional.

\subsubsection{Forma Externa/Campo}

A través de la forma externa o imagen, el diseño contribuye en la configuración de la escena visual del campo. Sus valores de representación mueven el entendimiento, la sensibilidad e imaginación de las personas, además de su conexión intrasubjetiva. A través de la escala, proporción, color, brillos, texturas los Concept cars capturan la atención de las personas no sólo hacia el auto sino de la proyección idealizada que ellas hacen de sí mismas a través de este objeto estético. El Concept Corvette, modelo de la división Chevrolet en su serie deportiva, inicia su desarrollo en 1952 con el concepto de auto deportivo de América, un automóvil aspiracional más esnobista que veloz según algunos críticos. 'Sí eres entusiasta de las carreras, un vecino urbano o un explorador de campo, o los tres, Corvette combina contigo ${ }^{52}$. Y remarca: la imagen típica del conductor Corvette es la de un hombre exitoso, de avance, con espíritu de riesgo y aventura, sofisticado y seductor, de ahí su icónico color rojo ${ }^{53}$.

Continuando con la belleza funcional GM; imagen idealizada de sujeto y de objeto, propone en esta forma externa más compacta, pero con exuberancia de detalles, un automóvil dotado con elegancia. El principio de imitación, el cual fue tratado como la inclusión de patrones previos de tipologías propias o externas, que acá se manifiestan con la línea orgánica, las secciones laterales, punteras y boceles en cromo, también la típica banda blanca en las ruedas. 


\subsubsection{Forma Externa/Forma Interna}

Bruno Munari en su libro de Diseño y comunicación visual (2016) hace énfasis en las interferencias que median entre el receptor y el mensaje visual del diseño. También llamadas "filtros" (p. 66) los clasifica en: sensoriales o fisiológicos, operativos fisio psicológicos y culturales. En su planteo, el diseñador debe trabajar en la correspondencia de la información que lleva el mensaje (la forma interna) y el soporte visual que corresponde a la forma externa a través de sus elementos compositivos como textura, forma, módulo, movimiento, forma parcial y color, que consolidan una unidad armónica y a la vez constituyen secciones, puntos focales para la experiencia perceptual. La forma externa posee sus propias reglas de composición como medio visual se adecúa al mensaje de la forma interna latente o invisible, pero es su aparecer el que determina o no el primer punto de conexión con las personas.

Ejemplos de punto focal en la forma externa como soporte visual del mensaje metafórico propuesto en su forma interna, pueden observarse en tres Concept de 1959: Cadillac Eldorado Biarritz Convertible, Cadillac Cyclone, Firebird III.

En la (figura 9) a la izquierda: aleta cola, a la derecha: las luces en la aleta y lámpara trasera del Cadillac Eldorado Biarritz Convertible 1959 evidencia de la representación de los proyectiles de aeronaves, pero con una narrativa con mensaje más empático: la belleza funcional en la aeroestética GM:

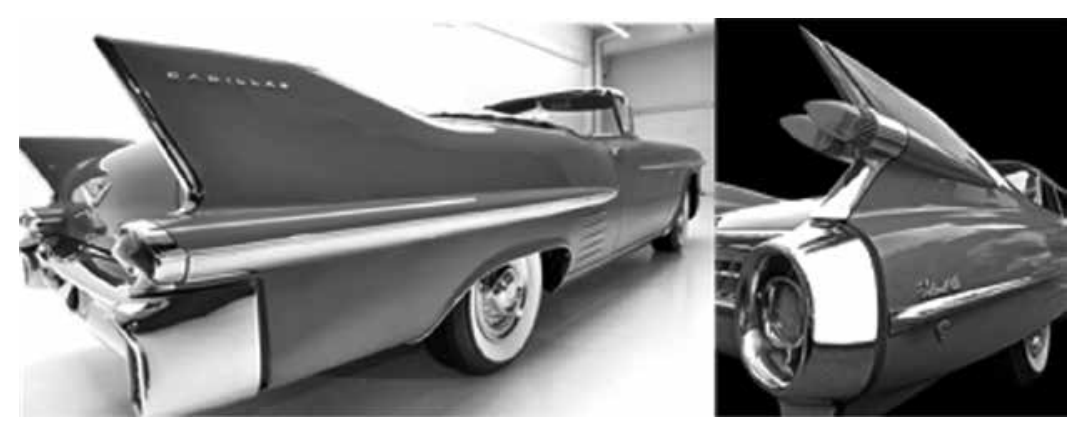

Figura 9. Foto Cadillac Eldorado Biarritz Convertible 1959 aleta y luz traseras. Y vista perspectiva del Cadillac Cyclone 1959 permiten apreciar la fuerza expresiva de su mensaje metafórico Fuente: GM Heritage Center.

\subsubsection{Forma Interna/Pensamiento Estético}

La forma interna como construcción narrativa, performativa ofrece un sentido para la interacción humana placentera con el objeto como medio de expresión del pensamiento estético. En tanto entrada o condicionante de éste, la forma interna de cada Concept car 
es una construcción única que busca alinearse con la intencionalidad de belleza funcional y subjetivizar la realidad objetiva que rige el campo tecnológico, normativo y de negocios. En esta praxis intencional, una fuerte dosis de ficción soportada en la creación simbólica ofrece al observador una cierta indeterminabilidad en su narrativa, para estimular el interés del observador. Los diseñadores GM construyen el mensaje, las personas al observar y poseer los autos proyectan una imagen de sí y toman conciencia de que la estética del objeto sí se ve y se siente (Gartman, 2004).

Veamos cómo se manifiesta en nuestro caso, con el Firebird, el cual alcanzó las versiones I (1952-54), II (1956-1958) y III (1958-1959) con foco en el III cuyo relato es 'luna, cohetes y hombres del espacio' Harley Earl y James Norman, como diseñador principal, lideran esta narrativa de anticipación del futuro del automóvil y la movilización tanto física como psíquica de los estadounidenses.

El Firebird III 1959 presenta su relato de ficción y metáfora: "El Auto nacido para la Era Espacial" "Nuestro intento era imaginar el automóvil que una persona podría conducir hasta el lugar de lanzamiento de un cohete a la luna"54:
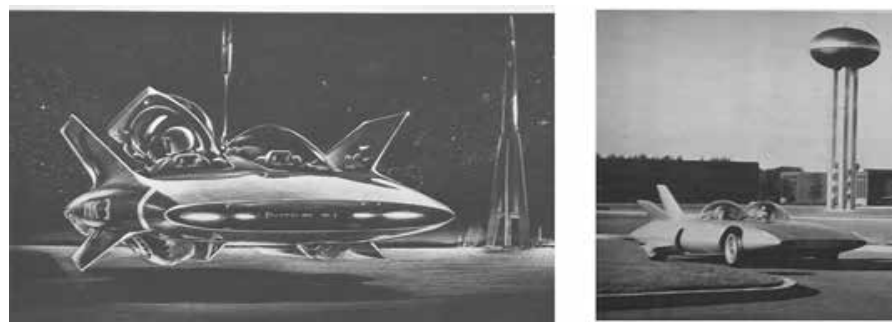

Figura 10. Foto Izquierda Magazine: Firebird in The Detroit News Pictorial Magazine, September 14 of 1958. Foto derecho: Firebird III en Campo. Fuente: GM Heritage Center.

\subsubsection{Forma Interna/Campo}

La forma interna como construcción autorreferente dijimos que es única, pero también referente porque sus raíces conectan con el campo de su génesis y apreciación. Como discurso performativo mueve la novedad y sorpresa frente a los contenidos normados que circulan social y culturalmente en representaciones mentales y manifestaciones materiales. Para los diseñadores GM, la forma latente de los Concept promueve una transformación en la apreciación de belleza y del modo de experimentar el objeto industrial, a objeto estético. La belleza como expresión de algo diferente que representa una imagen idealizada, compartida y avalada por los individuos impone sorprendentes relatos: 
Le Sabre es un modelo que se proyecta como: 'el automóvil que la sociedad desea pero que aún no conoce', la posibilidad de proyectar una imagen personal que va de lo formal del espacio de trabajo, al paseo con estilo en campo abierto, al evento en el club y la alternancia entre hombre y mujer en su conducción. Los Concept cars proponen un estilo de vida social y nuevas maneras de disfrutar el entorno. El diseño con sentido estético puede definirse como un medio para que los seres humanos puedan concebir y realizar nuevas posibilidades de crear significado y experiencia, dando forma y estructura al mundo a través de formas materiales con efectos inmateriales en experiencia de comunicación de los sujetos con los objetos en las diversas apariencias y sus propiedades de significado, plásticas y contextuales (Folkman, 2013).

\subsubsection{Forma Interna/Forma Externa}

La forma interna es a la externa como el pensar que guía el actuar del diseño. Es desde el carácter determinado en la forma interna o narrativa del mensaje estético que, los elementos compositivos de la forma externa se yuxtaponen en una estructura intencional para luego organizar la materia que la hace tangible y legible. En una perspectiva fenomenológica, las imágenes despliegan la relación entre lo que se ve en ellas y la multiplicidad de lo que muestran como atributos en su superficie refiriendo a sus relaciones internas. Los diseñadores GM de los Concept despliegan una exploración cuyo valor emerge cuando mueven los límites del orden simbólico socialmente normalizado y producen sus propias narrativas.

El Concept Corvette Mako Shark 1961 es una metáfora visual de correlación con el tiburón tanto en su morfología como en valores de su carácter de criatura bella, enigmática, poderosa y difícil de alcanzar (en su hidrodinámica). En tanto utilitario este Concept hace parte de los deportivos de lujo GM orientado a personas de espíritu determinante y aventurero, con un motor V8, la simbiosis de estética y tecnología adquieren un carácter único como el del tiburón. Con esfuerzos para alcanzar el color, las narrativas de diseño GM, cuentan que se ejecutaron más de 100 pruebas procurando imitar la tonalidad y gradación del color.

Si bien, con Lakoff y Johnson 1988 se mencionó que las metáforas de imagen o visuales se caracterizan por la proyección de estructuras de una imagen mental en otra, las metáforas de correlación proporcionan una serie de expresiones basadas en el dominio de origen o referente (tiburón) en este caso al dominio de destino (cuerpo del automóvil) que hacen legible su simbolización del cetáceo. En tanto propuesta de estética para el objeto, se potencia el agrado que las personas ya tienen por la morfología y o el carácter del tiburón, pero algunos de sus significados se deslizan para propósitos del diseño del Concept car en cuestión. Con la caracterización hecha a partir de las comparaciones binarias en diferentes modelos de los Concept cars, podemos afirmar que estos automóviles poseen las cualidades inmateriales y materiales del objeto estético. Como resultado del pensar - actuar, su estructura sinérgica muestra la correlación de los diferentes grupos compositivos y la coincidencia de sus contenidos perceptible en la imagen externa de su apariencia. Sí bien se reconoce como validez del caso, el contexto demarcado de investigación, esta praxis de diseño para la estética del objeto posibilita hacer legible su praxis, heredada de su enfoque pragmático. 
Otra característica del Concept car como objeto estético es constituir una manifestación material de una imagen autorreferente, con valores de representación de identidad y de belleza funcional para la conexión con el sujeto.

\subsection{Concept Car: Imagen De Objeto Estético}

Tomando algunos de los fundamentos del estudio de Catarano, Meirana y Papaleo (2000) acerca del mapeo del cuerpo del automóvil para analizar secciones, superficies, elementos compositivos claves para la apreciación del diseño estético y su impacto emocional en las personas procedemos en este apartado a observar la imagen externa del cuerpo del automóvil distinguiendo dos niveles: 1. Estructural superficie envolvente en tanto volumen general es considerada la unidad armónica con mayor impacto en la estimulación visual o primer punto de contacto con el observador. 2. Características de detalle que otorgan el carácter de autorreferencia, el conjunto de características (features) que pueden ser: secciones por cambio de plano, textura, color, brillo, rol funcional o accesorios. Sus roles: de contraste, novedad, diferenciación y punto focal o de atracción, (que corresponde al término kantiano de ornamento que estimula la experiencia estética).

La característica estructural representada en el cuerpo del automóvil se segmenta de la siguiente manera:

- Contorno: Es una línea o set de líneas que establece la silueta del cuerpo. Su eje es identificado como (beltline) o línea horizontal imaginaria (o ligeramente inclinada) debajo de las ventanas laterales que se extiende al capó y al maletero. Llamada también línea de horizonte, esta línea es crítica en el recorrido visual para la apreciación estética y de identidad del automóvil. Ligada a la apreciación estética es también asociada a la codificación de línea estilística de cada marca o serie de modelos como sí se tratara del código genético del mundo natural conocido como lenguaje visual de marca, antes mencionado.

- Carácter de las líneas como recurso geométrico, es la representación del mensaje del diseñador - marca inteligible en sus valores: semántico, simbólico y referencial de la apariencia. Las personas realizan asociaciones basados en el reconocimiento de patrones y significados.

Con las líneas llamadas de borde o límite se crean diferentes efectos de continuidad o cambio de plano de la superficie (edge - design); usadas intencionalmente para zonas de contraste, se acompañan con recursos como textura, brillo o color, además de la inserción de elementos que pueden ser de un material diferente. La importancia de este juego con líneas, planos y contrastes es el aumento de la atención y la riqueza de la apariencia según sea la intencionalidad.

Le Sabre 1951 y Firebird II 1958, con carácter autorreferente, comparten los mismos principios de composición; la superficie envolvente del cuerpo forma una unidad sin mayores interrupciones, pero juega con contrastes marcados para los puntos focales. Siendo sus formas internas completamente diferentes, el Firebird tiene más notoriedad en su mensaje simbólico de auto aeroespacial y supersónico. 


\section{Conclusiones Parciales}

1. La estética del Concept car es una fusión de composición narrativa, ficcional, metafórica expresada en un cuerpo que cobra fuerza expresiva con el detalle, la exageración de escala y proporción, pero también por la notoriedad de atributos formales como color, textura y sus brillos. Un dinamismo que capta la atención, curiosidad y fantasear de las personas por su juego de continuidad y contrastes, de novedad y sorpresa. En otras palabras, el Concept car como objeto estético posee diferentes dimensiones compositivas que se van estructurando sinérgicamente como una construcción de sentido para la anticipación de las cualidades perceptibles en su superficie material para la interacción humana placentera.

2. La noción de belleza del Concept car puede describirse como una expresión armónica de características propias de la categoría funcional del objeto y la representación de una imagen idealizada y de identidad compartida que es avalada socialmente como apariencia atractiva.

3. Es el producto del pensar - actuar y la intencionalidad del diseño; la estructuración de una información diversa que se organiza como narrativa autorreferente con mensaje metafórico, valores de representación de identidad, mensaje de ficción y un conjunto de cualidades formales con sentido estético.

4. Como salida de las operaciones relacionales y performativas, se trata de una estructura sinérgica de contenidos de pensamiento estético, campo, forma interna (carácter del mensaje), forma externa bajo principios compositivos para la figuración de la materia con cualidades estéticas y un medio de expresión del diseñador para provocar una resonancia emocional en las personas.

5. Como manifestación material una imagen autorreferente, valores de representación de identidad y de belleza funcional para la conexión con el sujeto. Ratificando la noción de autorreferencia como: la manifestación de rasgos propios y novedosos que el diseñador en su autonomía aporta al carácter estético de la forma sin detrimento de representación de su conexión con el contexto.

6. Los Concept cars de la GM además de autos de sueños son una manifestación única en su esencia formal. Su apariencia y aparecer son un par inseparable para el juego de intercambio que debe ser entretenido para estimular las emociones más que el discernimiento en la experiencia estética del espectador.

7. Su autenticidad puede transmitirse desde su duración material hasta su testificación histórica. A través de su contemplación e integración a la vida social y cultural de la sociedad estadounidense se integra a su vida cotidiana, sus rituales y al patrimonio de su cultura material. Los Concept cars GM en la actualidad se exhiben a nivel internacional no sólo en el ámbito del automóvil, también en museos como simbiosis estética y tecnológica en el objeto más significativo para la Modernidad. Con lo anterior podemos afirmar que este Concept car posee el carácter de aura en el sentido benjaminiano. 


\section{Conclusiones y Consideraciones Finales}

Esta tesis estudió la praxis de los diseñadores en sus operaciones y representaciones en correlación con su contexto socio histórico de génesis y apreciación haciendo legible el conocimiento oculto de su pensamiento estético, acto de diseño y forma del objeto. El resultado de esta investigación es un insumo para hacer legible el conocimiento de fundamentos para el diseño conceptual del carácter estético del objeto; la estructuración de una información que combina datos del contexto en sus diferentes categorías: sociológico-discursiva, referencial-expresiva y estética-experiencial con información producida por los diseñadores que corresponde a principios de composición formal y a una construcción progresiva de ideas que procuran una construcción singular o autorreferente.

Mediante la descripción conceptual de operaciones en cruce con la producción de un marco integrado de saberes, este trabajo ofrece una plataforma para el pensamiento proyectual en la concepción estética y para el análisis de la estructura formal. Se develó en la sinergia de contenidos de la estructura formal que hay un eje latente, narrativo (con dimensión semántica y retórico apoyado en las metáforas y la adjetivación) y otro visible o de forma externa que tratado como imagen da cuenta del mensaje interno.

Con base en lo expuesto, esta tesis está en condiciones de afirmar que la hipótesis central: La praxis del diseño de la estética de los Concept cars de los diseñadores General Motors en Estados Unidos entre 1945 y 1965 puede describirse como un pensar y hacer intencionales y condicionados por las circunstancias socio históricas y determinaciones institucionales que el diseñador agencia en su multidimensionalidad desde operaciones relacionales y performativas para concebir un carácter estético que es referente y autorreferente expresado como mensaje metafórico y de ficción en la apariencia del cuerpo del automóvil Concept car, ha sido constatada: el pensamiento estético como producto de una hibridación de valores de la ideología del campo, de la General Motors, de la proyección imaginativa de los diseñadores en su intercambio con las personas fue evidenciado en hallazgos como la adecuación y correspondencia de las metáforas verbales y visuales que proceden de referentes de contexto, de otras categorías funcionales, de la naturaleza, y que luego se concretan como imagen de la estética del auto: abundancia, libertad, expansión, progreso, anticipación del futuro, aeroestética con cohetes, aeronaves, alusiones hipersónicas, organicidad y de introducción de novedad, escala y proporción, materiales, contrastes, son algunos de los descritos a lo algo de este trabajo.

Mediante la descripción conceptual se constató como propuesta estética que hace fusión de la realidad y ficción en su mensaje simbólico, en la apariencia del automóvil y de su aparecer en la feria de Motorama donde la dimensión estética de expresión sensible, de interacción dialógica sujeto - objeto fueron manifiestas.

Representaciones verbales, gráficas y orales mostraron la producción de referentes y conceptos que existen en una expresión comprensible y provocadora de fantasía en otros; para el caso un enlace con la utopía estadounidense y el estilo de vida americano, como también un relato institucional como valor diferenciador de la General Motors en su propuesta disruptiva frente a los arquetipos precedentes fueron explorados, descritos conceptualmente y caracterizadas sus relaciones para dar lugar a la estructura formal. 
Con lo anterior se puede mencionar que, en tanto fenómeno esta praxis con sentido estético da cuenta de su construcción singular con relación a las condiciones históricas particulares a las que se sumaron otras de orden tecnológico, empresarial y cultural en las que los diseñadores GM fijaron una posición autónoma, disruptiva pero también de adecuación y correspondencia en su codificación para facilitar sus asociaciones.

Con relación a la concepción estética de los diseñadores de los Concept cars se partió de la hipótesis de que esta se caracteriza por ser una fusión que es referente del contexto y autorreferente como excedente de novedad dada a una expresión performativa con mensaje metafórico y de profusión en las cualidades formales de la estructura material de un objeto que se manifiesta como mediación para la experiencia estética.

La constatación de esta hipótesis se evidencia en que la concepción estética además de ser una fusión referente de valores de identidad, de patrones, de valores de la ideología, de la utopía estadounidense, el estilo 'hiper dimensionado' de la sociedad, su estética incorpora rasgos de líneas curvilíneas y orgánicas del Streamline, el gran formato del auto americano, la morfología de las aeronaves y dispositivos de guerra, y todos esos datos que el diseñador abstrae, organiza, sintetiza como información dan forma a su objeto.

$\mathrm{Al}$ verificar que es auto referente se halló que constituye un concepto que da cuenta de su carácter propio: Por ej.: Concept cars más largos que anchos, más ornamento, profusión en los detalles, fuerza expresiva en el tratamiento del color, la textura, brillos y contrastes corresponden a la producción de un mensaje propio que intenta conectar con las personas. La novedad es introducida en el mensaje simbólico, el uso de otros materiales, la aplicación de morfologías de otras categorías referentes, pero principalmente, la mirada del objeto como una mediación para la experiencia estética. Como construcción única, el diseño de los Concept cars se evidenció su autonomía y carácter singular, disruptivo, con una narrativa propia que se conecta con su realidad.

$\mathrm{Al}$ respecto, de la noción de mediación estética este trabajo fue limitado a su fundamentación teórica desde la Psicología perceptual y la Estética que facilitara el rastreo de la intención de la concepción de cualidades en función de la interacción dialógica sujeto - objeto (y no para verificación desde el receptor). De allí se obtuvo que en la praxis Concept cars con su feria Motorama, la apariencia y el aparecer del objeto se conciben como un par inseparable; así el objeto estético es una mediación para la conexión subjetiva, sensible de la persona con su apariencia como también un medio para la experimentación de lo que su entorno ofrece. Con el uso personal de modelos como el Y-Job, Le Sabre, Cadillac en sus diferentes modelos y Corvette por parte del diseñador, la dimensión relacional para la co-creación a partir del intercambio con las personas es develada.

Como naturaleza performativa identificamos sus características de enunciación provocadora y subjetiva para que el receptor le otorgue sentido. Está vinculada a su memoria y a su realidad presente. En su constitución progresiva y relacional se constató que no es un libre ejercicio, sino una práctica que requiere agencia y reflexividad para fusionar precedente y novedad. Con el propósito de que los diseños tenían que ser agradables con funcionalidad también se proyectaban imaginarios que circulaban en la sociedad y se representaron valores de identidad estadounidense del período 1945-1965.

En función de esto, esta investigación hace un aporte a las características distintivas del diseño de la estética del objeto y su correlación con el contexto para producir la informa- 
ción que estructura la forma narrativa - figurativa del objeto con contenidos de la realidad y de la ficción, así que se hace legible el componente subjetivo en la concepción formal. Con el caso analizado se realiza una deconstrucción de las operaciones del acto de diseño encontrando que el eje relacional está presente en el manejo de información, por ej.: con el esquematismo el cual fue abordado como recorte de la realidad para obtener representaciones que el diseñador capta, asocia, discrimina, sintetiza e incorpora a su acto creativo. Fueron mencionadas como categorías: la sociológica-discursiva mostró el enlace con el campo, habitus, gusto, ideología. En la categoría referencial-expresiva se evidenció el vínculo con las expresiones de arquetipos, íconos que orientaran patrones de preferencia, de la abstracción de ideas, de comparativas con el rival, con material empírico del entorno. En la categoría experiencial - estética, la relación de fundamentos de la experiencia sensible y de apreciación mostraron una adecuación y correspondencia con su concepción e intencionalidad estética.

Luego otro nivel relacional corresponde al trabajo colaborativo de los diseñadores entre sí, con colegas de otras disciplinas, personas en un intercambio de narrativas, ideas, imágenes que soportan a la concepción y composición formal para la estética del objeto.

En términos de la estructura formal, se trata de una red de relaciones de interdependencia de los elementos compositivos de la forma identificados: pensamiento estético, campo, forma interna y forma externa que deben conformar una coherencia y correspondencia como unidad armónica. Esta constatación es relevante para comprender la multidimensionalidad de la estructura formal y la carga de contenidos que se enlazan a datos externos de realidad presente y precedente.

Otra relación fundamental refiere a la del sentido estético: sujeto - objeto en el que el primero capta sensiblemente el mensaje y cualidades del objeto. Esa interacción implica para el diseñador una figuración atractiva que resulta del balance de la concepción del carácter del mensaje y su expresión en una figuración que sigue además sigue leyes compositivas. Sobre la última hipótesis: lo que distingue al Concept car como objeto estético son sus cualidades de expresión autorreferente y referente en una apariencia armónica que exhibe profusión en sus detalles y mensaje metafórico, de fusión y ficción en su conjunto. El análisis de comparaciones binarias de los cuatro grupos compositivos de la forma permitió constatar la consistencia, adecuación y coherencia con relación a la imagen externa de los modelos de la muestra.

Esta hipótesis anticipó unas cualidades de la expresión de la imagen del cuerpo del automovil con relación a las concepciones del pensamiento y acto de diseño, relevando que en tanto producto del pensar-actuar; la información referente y autorreferente es además una señal de intersección de información diversa que adquiere un sentido estético. Como manifestación material con cualidades visual, sensorial, cognitiva y sensiblemente apreciables se dio cuenta de la consistencia entre intención-composición y concreción.

Como reflexión complementaria, se puede mencionar que debiera profundizarse más en el seguimiento y estudio del diseñador como actor clave para comprender la relación de las habilidades acá rastreadas: agencia, reflexividad, interpretación con su proyección imaginativa. Dadas las limitaciones y enfoque de la investigación histórica, únicamente fue posible interpretar la carga subjetiva de sus narrativas y no ir a la indagación por su sensibilidad como balance a su entendimiento. 
Partiendo de la necesidad de hacer legible el diseño de la estética del objeto, se transitó simultáneamente por dos caminos: El primero referente al estudio de diferentes teorías para describir y conceptualizar el sentido estético del pensamiento, el actuar y el producto del diseño. Ello implicó poner en diálogo la Estética, las Humanidades y el Diseño procurando comprender el componente subjetivo o de sensibilidad que está presente en la concepción de la forma, y ofrecer un marco integrado de fundamentos que permitieran para el segundo camino: La deconstrucción de una serie de representaciones, operaciones y relaciones estructurales de la práctica para hacer legible el conocimiento oculto de un legado en la historia del Diseño Industrial.

A través de un desarrollo progresivo que inició con la indagación teórica con apertura a múltiples miradas, se realiza un marco integrado, el cual constituye la primera forma de comprobación de principios, nociones, factores clave por la coincidencia y repetición o por verificaciones realizadas especialmente de disciplinas de corte positivista o desde las ciencias sociales.

Con el esquematismo de la realidad, ejecutado mediante la reconstrucción histórica, la naturaleza fenoménica, con tensiones y paradigmas propios del contexto espacio temporal son ratificados en tanto entradas y fundamentos para la formación del pensar que guía el actuar del diseño.

Una vez deconstruidas las operaciones de diseño con foco en la conceptualización y composición formal, esta se confrontó con la imagen del objeto como punto de articulación y expresión de las dimensiones estéticas. Sí bien no se incluye en las hipótesis reconocemos la complejidad de constatación de la expresión 'belleza funcional' de esta praxis limitándonos a una búsqueda de consistencia entre su intención conceptual y en su manifestación en diferentes expresiones en el cuerpo del automóvil; tal fue el caso de: lámparas, punteras, cabinas o panorámicos del objeto. Su verificación implicaría testeos y validaciones que están fuera del alcance del presente trabajo.

A partir de una síntesis, con análisis crítico y correlacional se procedió a describir conceptualmente el fenómeno con foco en el conocimiento que logró hacerse legible. Y procuró explicar en sus hallazgos, el sentido estético del diseño formal del objeto, los valores de relación que implicaron una construcción que inicia con un recorte de la realidad, el reconocimiento de valores de alteridad, de la conjunción de sensibilidad y entendimiento para producir una fusión referente y autorreferente que suma objetividad y subjetividad. Un trabajo explicativo que, sin pretensiones de validez universal en las unidades significativas que expone desde saberes de la teoría, apunta a la plausibilidad del desocultamiento del conocimiento mediante una narrativa histórica que da cuenta sistemática de una construcción progresiva del pensamiento y actuar proyectual con representaciones como expresión explícita de su manifestación en el cuerpo del automóvil.

Con sus resultados, aporta una plataforma conceptual integrada en diálogo con el Diseño, relevando el complemento del sentido estético del diseño del objeto con disciplinas principalmente de las humanidades. Caracteriza las operaciones distintivas del acto de diseño, describe las concepciones que hacen al pensamiento estético, ofrece instrumentos para el análisis de la imagen del objeto para comprender e inferir sus cualidades estéticas y cómo está producida su estructura formal. Como diseño y desarrollo de investigación, este trabajo combinó diferentes perspectivas para la comprensión holística de un legado del Diseño. 
Con relación al estudio combinado de teorías y de la praxis Concept cars GM en procura de un marco integrado, se obtuvo:

La Estética signa como características distintivas:

1. Naturaleza relacional entre sujeto - apariencia y aparecer del objeto para conectar con la sensibilidad e imaginación más que con el entendimiento. En ese sentido la estética del objeto extiende su categoría utilitaria a una interfaz que invita al sujeto al disfrute de sus cualidades latentes y de las tangibles de la forma.

2. La concepción estética reconoce una correlación existencial entre el sujeto y el contexto para configurarse mutuamente.

3. Lo objetivo y lo subjetivo, lo utilitario y lo atractivo, la razón y la sensibilidad se hacen manifiestas como tensiones estructurantes de la concepción del sentido estético. La creación de belleza del objeto, precisa la producción de ideas estéticas para complementar los conceptos lógicos y de la categoría funcional, para crear los atributos de captación sensible, de la hibridación de ideas precedentes y originales, de la agencia de complejidad y de una ética estética.

4. El sentido estético del diseño formal está asociado a la esencia de la creación del objeto estético, a una estructura de correlación entre lo que toma de sus raíces y las señales que emite en nuevas direcciones para una percepción cercana y fascinante. El sentido está conectado con la intersubjetividad del individuo y su voluntad para captar no sólo la forma visible y palpable, sino también su contenido latente e invisible, ello implica poner en juego los sentidos, la sensibilidad y el entendimiento.

5. La noción de belleza del objeto puede describirse como una expresión armónica de características propias de su categoría funcional y la representación de una imagen idealizada y de identidad compartida que es avalada socialmente como apariencia atractiva.

6. La naturaleza fenoménica de la estética y su foco en la dicotomía sujeto - objeto se mueve entre pares polares estructurantes de su naturaleza, así cualidades estéticas versus condición de subjetividad, lo normado versus lo único, la continuidad y discontinuidad son una de la serie que el creativo debe balancear.

Desde lo sociológico - antropológico:

1. El pensamiento estético es una construcción mental, intencional y performativa que surge de organizar ideas, representaciones de la realidad presente y otra imaginada para concebir el carácter de autorreferencia a las cualidades de la apariencia del objeto. Como testimonio del tiempo y espacio en que es creada, posee códigos compartidos con los individuos para poder comunicarse y sostener el nuevo sentido propuesto.

2. El diseñador en su comprensión del contexto y del sujeto, ofrece como bello algo que no sólo es captado en las cualidades visibles e invisibles de la forma, sino que, a través de su apariencia, le permite al sujeto proyectar una imagen de cómo quiere verse y cómo quiere ser visto a través de ese objeto.

3. La concepción estética posee rasgos de ficción, representación de valores de identidad, simbolismo de los imaginarios y figuraciones propias del concepto del objeto y deslizamientos de referentes precedentes que circulan en la sociedad y que yacen en su cultura material desde otras expresiones de diseño. 
4. El diseño de la estética del objeto puede describirse como un fenómeno socio históricamente localizado es un proceso progresivo intencional de producción de información e imagen que expresa mensaje metafórico y composición plástica con carácter de autorreferencia como resultado del pensar y actuar del diseñador en su intercambio con la realidad del contexto para su conocimiento y la proyección de medios adecuados con apariencia atractiva para la conexión sensible de las personas con los objetos, según su adecuación y correspondencia a su juicio de gusto.

5. La estética del objeto está contenida en el valor intrínseco del objeto, en su mensaje de realidad y ficción y no sólo en las propiedades de tradición canónica.

Desde su dimensión comunicativa:

1. La apariencia estética es una expresión performativa; una enunciación evocadora de referentes y de cualidades de ficción provocadoras para que otros le otorguen sentido.

2. Como conjunto de cualidades, posee un carácter distintivo como resultado de una producción de narrativa con mensaje metafórico y profusión de detalles.

3. La belleza significa una expresión de algo que funciona y que representa una imagen idealizada, compartida y avalada socialmente.

Desde el Diseño:

1. El diseño es un pensar en acción que produce conocimiento derivado de su experiencia en el intercambio con su entorno así que evoluciona de la aprehensión de conocimientos previos, referentes para producir su propio sentido.

2. El acto de diseño para la estética del objeto se trata de un conjunto de operaciones relacionales y performativas que el diseñador desarrolla soportado en su pensamiento, intercambio con el contexto y sus habilidades proyectuales de observación, interpretación, imaginación, reflexividad y agencia.

3. Dos operaciones son fundamentales para el acto de diseño de la estética del objeto: el esquematismo y el diseño conceptual. Con el primero, el diseñador ve para conocer, asocia y pone en tensión, discrimina, sintetiza y organiza una información que en principio es externa e inconexa con otra interior. Con el diseño conceptual como descriptiva de una anticipación de cualidades y del modo de mediación de la estética del objeto, también se constituye una trama entre lo precedente, lo real y lo imaginado donde el diseñador pone su voz.

4. El diseñador en tanto sujeto intersubjetivo en procura de un resultado objetivo en el marco de un objeto industrial desarrolla habilidades proyectuales significativas que le dan un valor distintivo frente a otros colegas de diversas disciplinas: socialización a través de operaciones retóricas como la metáfora, las narrativas ricas en adjetivación y el liderazgo para la co-creación.

5. El objeto estético como salida de las operaciones relacionales y performativas se trata de una estructura sinérgica de contenidos de pensamiento estético, campo, forma narrativa, forma externa bajo principios compositivos para la figuración de la materia con cualidades estéticas y un medio de expresión del diseñador para provocar una resonancia emocional en las personas. 
Nuestra reflexión sobre la investigación:

$\mathrm{Al}$ seguir de manera diacrónica el fenómeno, pudo develarse la importancia de tomar del pasado para proyectar lo que aún no existe (el componente ficcional), en el presente. Este caso mostró una hibridación de lo precedente con referentes de otras categorías para producir conceptos de ficción que cobraran sentido en el presente. Con el estudio sincrónico pudieron explicarse las relaciones de diseño - contexto para configurarse mutuamente: pensamiento proyectual y lo que el diseño luego ofrece al contexto para facilitar su asociación. Con relación a la utilización del conocimiento, este trabajo aporta nociones y hallazgos que nutren el debate teórico y también sirve como una referencia del conocimiento que ha legado un equipo de diseñadores con desafíos equiparables a los de la realidad actual: la concepción formal en su dimensión estética, sus ejes inmaterial y material con relación a los modos de su experimentación en contexto.

Proyecto e investigación tienen mucho en común, este trabajo ofrece un referente de indagación, de interacción multidisciplinar que comporta un manejo de complejidad como fue expuesto: un recorte de la realidad conciencia de la imposibilidad de abarcar la totalidad pero sí de constituir un conjunto de fundamentos que guíen una construcción progresiva, consciente e intencional. Con el marco integrado de términos desde las teorías y su enlace al análisis crítico de la práctica y del artefacto obtenido, tanto estructura formal como objeto material, se cuenta con un insumo de reflexión.

Con relación a la replicabilidad de los fundamentos y el conocimiento que se hace legible como pensar - actuar y objeto con sentido estético, la presente tesis ofrece un desarrollo extensible a otras expresiones y prácticas del diseño; su desarrollo puede verse como un diseño centrado en la conexión sensible sujeto - objeto con relación al contexto y un complemento al componente lógico paramétrico de la morfología.

Finalmente, al tratar la forma como información para la relación dialógica, se ofrece un complemento a la mirada de composición formal resuelta a través de softwares.

Como mención de hallazgos no esperados podemos destacar el carácter performativo y relacional del diseño en su componente de estética del objeto:

1. El sentido de la estética del objeto es el diálogo con el sujeto desde su sensibilidad e imaginación más que con el entendimiento. Un juego donde la imagen del objeto (expresión performativa) activa el interés y la libertad del receptor para encontrar una forma de representación que armoniza consigo mismo.

2. El pensar - actuar del diseño para la estética del objeto comporta un intercambio entre el diseñador y el contexto en el que ejecuta un encuadre de la realidad, el cual alimentará su producción imaginativa y faculta una expresión performativa que posee valores compartidos con los individuos. Esto implica para el diseñador, articular lo sociológico-discursivo (identificación de sujeto con discurso ideológico y convenciones sociales), lo referencial-expresivo (referentes y representaciones que modelan fantasías y preferencias) y la experiencia estética (interacción placentera - subjetiva del sujeto con el objeto para otorgarle su propio sentido).

3. El diseño para la estética del objeto implica encadenamientos de significado de la información obtenida que le lleven del 'caos al orden' de sentido estético. Una confrontación de sistema de referencias y la construcción de nuevas o fusionadas. 
4. La forma como estructura sinérgica de contenidos es una trama de relación de interdependencia de elementos que poseen una esencia individual pero que conectan como unidad armónica.

Como operación performativa identificamos estas características:

1. Acto de expresión de lenguaje que en sus narrativas: verbal y visual, posibilita la comunicación con lo simbólico y lo metafórico. Ese sentido expresado como narrativa en cada Concept car puede interpretarse como una historia que habla de una imagen autorreferente idealizada y sensible del sujeto proyectada en el contexto a través del objeto

2. Es autorreferente al tratarse de un acto único ejecutado en circunstancias particulares, constituye su propio carácter y estructura de concepciones de una nueva realidad. Y es, a la vez, referente porque se corresponde a una estructura normada socialmente que le otorga sentido y le avala.

3. Transitando de las ideas a la acción de concretarlas produce efectos inmateriales y materiales. Para el caso del diseño, produce expresiones enunciativas y provocadoras para la experiencia subjetiva y sensible que se vehiculizan en la imagen del objeto.

4. Tratándose de un acto de creación que no es totalmente libre ejerce la autonomía para la construcción de su ficción y valor identitario.

Por último, se postulan las siguientes iniciativas de investigación:

1. Ética estética y componente sociológico del diseño formal.

2. Diseño de la estética del objeto y su mediación para el bienestar emocional de la sociedad.

3. Forma material e inmaterial desde la concepción estética del diseñador.

4. Diseño estético y respuesta afectiva, testeo de conceptos y composiciones rotadas en diferentes contextos socio culturales.

5. Materiales y sus cualidades para la experiencia estética del objeto.

6. Conceptualización de la Estética en el Diseño y su aplicación en la producción de espacio e imagen.

\section{GLOSARIO}

\begin{tabular}{|c|c|}
\hline Agencia & $\begin{array}{l}\text { Habilidad proyectual del diseñador de asumir una posición de ac- } \\
\text { ción consciente e intencional apoyado en la reflexividad, su bagaje } \\
\text { cognitivo y sensibilidad para alcanzar una meta. Con la agencia se } \\
\text { procura un balance entre autonomía y adecuación (Crouch y Pearce, } \\
\text { 2013; Giddens, 1991, p. 126). }\end{array}$ \\
\hline Aura & $\begin{array}{l}\text { Carácter que otorga al objeto un poder de saturación en el mensaje; } \\
\text { ornamento y detalle en su aspecto y una presencia social tal, que le } \\
\text { hace permanecer en el tiempo. 'Aura es la cifra de todo lo que puede } \\
\text { transmitir la imagen desde su testificación material hasta su testifi- } \\
\text { cación histórica' (En Morcillo, 2013, p. 95). }\end{array}$ \\
\hline
\end{tabular}




\begin{tabular}{ll}
\hline Belleza & Simbiosis estética y tecnológica. Expresión de cualidades plásticas, \\
Funcional & simbólicas y conceptuales en el objeto funcional y que representa \\
& una imagen idealizada, compartida y avalada socialmente ya sea de \\
& ese objeto o del mismo sujeto. "Harley Earl to Inter-organization le- \\
& tters only, Styling Division, Field where designers operate. Concept \\
& car Le Sabre Project. 16 January 1953, New York General Motors \\
& Corporation, New York City". \\
\hline Campo & Sistema de posiciones y sus relaciones objetivas con una existencia \\
& temporal. Posee una estructura con relación al momento histórico, \\
& en tanto capital: (simbólico, cultural, social) acumulado que orienta \\
& las estrategias de los actores (diseñadores en su campo de operación) \\
& en la sociedad. Es abordado como un estado de relaciones de fuer- \\
& za entre las instituciones y los diseñadores quienes establecen una \\
& dialéctica de adhesión, conservación o transformación (Bourdieu, \\
& 2010, p. 74; Althusser, p.75). \\
\hline Carácter de & El carácter de autorreferencia refiere al conjunto de propiedades que \\
autorreferencia & otorgan una singularidad y autonomía al mensaje estético del objeto \\
en el espacio social que lo aprecia, vivifica y perdura como goce esté- & tico (respuesta placentera frente a sus atributos). Entre sus atributos \\
& se resaltan: novedad, familiaridad, autenticidad.
\end{tabular}

\begin{tabular}{ll}
\hline $\begin{array}{l}\text { Dimensión } \\
\text { sociocultural }\end{array}$ & $\begin{array}{l}\text { Agrupación de valores y constructos que un colectivo humano com- } \\
\text { parte y percibe como legado de previas generaciones y expresiones } \\
\text { en el entorno: físico, mental y sensible (Hofstede, 2005, p. 23). }\end{array}$ \\
\hline
\end{tabular}

Esquematismo Operación cognitiva y sensible que se apoya en la observación, la interpretación y la proyección imaginativa para captar de la realidad presente información estructurante del diseño conceptual. El acto de producir una matriz sintetizadora de conceptos agrupados en categorías. Un modo de experiencia del individuo para conocer su entorno sensorial, mental y sensible.

\begin{tabular}{ll}
\hline Esquema & Matriz estructural que posee sus propias reglas sinérgicas y contiene \\
& una red de conceptos organizados como construcción de sentido in- \\
& terno a partir de la imaginación, pero significativos por medio de la \\
& experiencia y el conocimiento ya adquirido. \\
& Instrumento de socialización de ideas: mapa, boceto, red de relacio- \\
& nes o figuraciones (Piaget, p. 51). \\
\hline Estética & Doctrina de la experiencia sensible y de las manifestaciones inmate- \\
& riales y materiales con cualidades de conexión con las personas por \\
& sus cualidades latentes o invisibles y otras visibles y legibles cons- \\
& tituidas intencionalmente. Para el diseño, una plataforma concep- \\
& tual que guía el pensar y actuar para el diseño de la apariencia y el \\
& aparecer del objeto de manera consciente, intencional, relacional y \\
performativa.
\end{tabular}




\begin{tabular}{|c|c|}
\hline Estereotipo & $\begin{array}{l}\text { Concepción, imagen, patrón, significantes normalizados dentro de } \\
\text { la estructura social que, a la vez, le identifica (p. 56). }\end{array}$ \\
\hline $\begin{array}{l}\text { Experiencia } \\
\text { estética }\end{array}$ & $\begin{array}{l}\text { Experiencia que constituye una entrada a lo real, sino un paso más } \\
\text { allá de los confines es vinculada a representaciones sensibles que no } \\
\text { son perceptivas, y por ello son estéticas; no refieren a un presente } \\
\text { actual, sino a un presente ausente (p. } 70 \text { ). }\end{array}$ \\
\hline Gusto & $\begin{array}{l}\text { Preferencia por determinadas representaciones como preconcepción } \\
\text { de belleza por asimilación de leyes perceptuales, patrones, imágenes } \\
\text { y significados de valor simbólico a partir de la experiencia personal } \\
\text { y la socialmente construida desde las diferentes expresiones del en- } \\
\text { torno. Implica pensamiento y sentimiento. Un acuerdo colectivo de } \\
\text { signo social (Bourdieu, p. } 67 \text { ). }\end{array}$ \\
\hline Habitus & $\begin{array}{l}\text { Principio generador y organizador de prácticas y representaciones } \\
\text { adoptadas socialmente. Los habitus exteriorizan los gustos y las pre- } \\
\text { ferencias estéticas según las representaciones que tienen de ellas, y la } \\
\text { apertura que las personas tienen a la invención y necesidad. Se dis- } \\
\text { tingue del hábito en que éste corresponde a una rutina de conducta } \\
\text { que se repite consciente e inconscientemente (p. } 76,179,180) \text {. }\end{array}$ \\
\hline Idea Estética & $\begin{array}{l}\text { Representación de la imaginación para la producción de atributos es- } \\
\text { téticos, aquellos que son captados por el sujeto como de valor sensible. }\end{array}$ \\
\hline Identidad & $\begin{array}{l}\text { Set de valores, rasgos, ideas y concepciones de un individuo o colec- } \\
\text { tivo particular por el cual es distinguido por otros (Krippendorff, } \\
\text { 2006, p. 162). }\end{array}$ \\
\hline Ideología & $\begin{array}{l}\text { La creencia en la que el colectivo cree adhiere o se adapta para fluir } \\
\text { socialmente. Poder significante que pauta la relación imaginaria en- } \\
\text { tre los individuos y las condiciones reales de su existencia. Construc- } \\
\text { ción semántica que mezcla fantasía, identificación y goce; es insumo } \\
\text { de la conceptualización del carácter estético en el diseño formal del } \\
\text { objeto (p. 102). }\end{array}$ \\
\hline Imagen & $\begin{array}{l}\text { Del latín imago refiere a una representación de algo que puede ser } \\
\text { perceptible por su aparición sensible ya sea en la imaginación o en el } \\
\text { mundo físico. Por lo tanto, puede ser mental o real; en tanto realidad } \\
\text { material implica asumirla como objeto portador de una cierta in- } \\
\text { tensidad que presenta cualidades que mantienen su apariencia pre- } \\
\text { sente (volumen, color, textura, material) y en tanto representación } \\
\text { un mensaje que estimula la comprensión de sentido en el receptor } \\
\text { además de su apreciación (Seel, 2010). }\end{array}$ \\
\hline Imaginación & $\begin{array}{l}\text { Actividad cognitiva que se produce en el intercambio de imágenes } \\
\text { externas e internas para la producción de otras nuevas. Capacidad } \\
\text { de abstracción de datos de la realidad para llevarlos a nuevas expre- } \\
\text { siones mentales, físicas y sensibles. }\end{array}$ \\
\hline
\end{tabular}




\begin{tabular}{|c|c|}
\hline Legible & $\begin{array}{l}\text { Una entidad, estructura o concepto que faculta su comprensión por } \\
\text { la lectura de sus características, carácter, razón de ser o intenciona- } \\
\text { lidad. }\end{array}$ \\
\hline Metáfora & $\begin{array}{l}\text { Innovación semántica. Recurso de construcción mental para repre- } \\
\text { sentar una cosa por otra. Mecanismo de representación de valores } \\
\text { esenciales de una entidad como deslizamientos hacia nuevos con- } \\
\text { ceptos y o representaciones. }\end{array}$ \\
\hline Reflexividad & $\begin{array}{l}\text { La capacidad de intercambio de información en orden de decons- } \\
\text { truirla acorde a la realidad cognitiva, física y sensible del individuo } \\
\text { en función de identificar la relación subjetiva con a la realidad ob- } \\
\text { jetiva que hace al individuo y a las circunstancias. Para el diseñador, } \\
\text { una habilidad proyectual para comprender cómo lo externo cons- } \\
\text { tituye las manifestaciones del diseño y lo que él puede hacer para } \\
\text { producir su voz (p. 169). }\end{array}$ \\
\hline
\end{tabular}

Representación Es la referencia a algo que se corresponde por semejanza, coincidencia, evocación del conjunto de sus atributos con un concepto, imagen o entidad previamente reconocidos. Es una imagen que evoca o sustituye una realidad y así faculta la relación entre lo que se ve y lo que no se ve pero que es susceptible de ser asociado por los rasgos presentes en una apariencia legible. A partir de ello, la representación es también un símbolo.

\begin{tabular}{ll}
\hline $\begin{array}{l}\text { Semántica del } \\
\text { producto }\end{array}$ & $\begin{array}{l}\text { Campo de estudio de la estructuración de contenidos de significado } \\
\text { simbólico, de identidad social y cultural que otorgan cualidades ob- } \\
\text { jetivas o de codificación y tras subjetivas o de sentido interpretativo } \\
\text { a la composición del objeto de diseño (Krippendorff, 2006, p. 1). }\end{array}$ \\
\hline Sentido & $\begin{array}{l}\text { Es la suma de atribuciones significativas, imaginativas y de valor que } \\
\text { las personas atribuyen a un fenómeno comprensible de su realidad } \\
\text { mental, física y sensible (Krippendorff, 2006, p. 50). }\end{array}$ \\
\hline Símbolo & $\begin{array}{l}\text { Representación de valores que transmiten significados específicos } \\
\text { para colectivos específicos en un contexto espacio temporal localiza- } \\
\text { do. Un medio de expresión de los diferentes contextos imaginativos }\end{array}$ \\
& que las personas comparten (p. 103). \\
\hline Significado & $\begin{array}{l}\text { Unidad comprensible relativa a circunstancias de interpretación re- } \\
\text { gladas por un sistema codificado. }\end{array}$ \\
\hline Sociedad & $\begin{array}{l}\text { Colectivo humano ubicado espacio temporalmente que comparte un } \\
\text { territorio físico, de ideologías, imaginarios, habitus, capital simbóli- } \\
\text { co, intelectual, cultural y de otras naturalezas (Bourdieu, 2013, p. 72). }\end{array}$ \\
&
\end{tabular}




\section{Notas}

1. Pierre Bourdieu (1984) alude a la percepción del valor estético en el objeto como un fenómeno sociológico, donde factores como estatus social; presión de proyectar una imagen y posición de conformidad a un grupo social son relevantes en el juicio del gusto. El gusto es abordado como un fenómeno social de acuerdo temporal de patrones de preferencia y como signo de distinción.

2. Goldstein, E. B. (2002). Sensation and perception, Sixth Edition Pacific Grove, CA: Wadswoth. Ofrece un marco de comprensión de las funciones sensoriales, definiendo que un propósito central de la percepción es informar sobre las propiedades del entorno para la supervivencia (p. 2).

3. David Gartman (1994) (pp. 27-70) Streamlining es conocido como un movimiento estilístico que se caracteriza por sus formas orgánicas, curvilíneas. Fue reinterpretado en los automóviles como recurso de figuración y materialización que alude al desempeño aerodinámico y la ruptura del paradigma ortogonal que había instaurado la línea Ford desde los 1920's. El streamline es desarrollado como factor de novedad, contraste y valor de atracción para las personas. El uso de líneas orgánicas que promovieron como aerodinámicas reforzarían la concepción de velocidad y liberad del pensamiento estético en la industria del automóvil. Su implementación implicó altos desafíos en la manufactura en tanto conformación de materiales como de ensamble y una alta producción narrativa.

4. Desde el sentido aristotélico, un sentido de reciprocidad entre la forma de pensar la acción y una forma de actuar sobre el pensamiento que implica un sentido de obligación social y ética para los individuos libres de agenciar sus acciones. Con la theoria se hipotetiza el mundo en una vía de entendimiento para pensar cómo pueden ser las cosas, con la práctica, se piensa cómo las cosas pueden ser y son hechas. Una oposición entre la teoría y práctica se manifiesta como dicotomía, es decir tensiones o pares polares que en cuanto opuestos también se complementan entre sí. Juntas hacen a la praxis y ésta permite pensar acerca de la agencia de un individuo, la situación histórica que forma la determinación del ser de una cosa en tanto construcción humana intencionada y las consecuencias de su acción como producto en su validación histórica.

5. En Gjoko Muratovski en su libro Research for Designers (2016) p. 93. Hines (2009), afirma que, en la investigación histórica del Diseño, la consulta de investigaciones históricas desarrolladas generalmente de disciplinas del corte de las humanidades ofrece datos que pueden interpretarse como evidencia histórica en el sentido que ya ha sido constatado su validez en el marco de la investigación.

6. Ver Gjoko Muratovski en su libro Research for Designers (2016). Visual Analysis.

7. (con relación al diseño es la representación sensible de la experiencia humana, el componente de subjetividad en la interacción sujeto - apariencia del objeto, la intersección de apariencias sensuales y conceptos impregnados de pasado y presente, de realidad y ficción). 8. (aporta nociones que permiten interpretar, sistematizar y explicar diversos sub-fenómenos sociales, sus relaciones estructurales, ligados a la producción, circulación de simbolismos e imaginarios que inciden en la apreciación y consumo del valor estético y simbólico de los Concept car). 
9. (el diseño de la estética se asienta en operaciones retóricas como recursos performativos con mensaje metafórico, desde la semántica de producto se ligan contenidos simbólicos y de significación cultural a otros que corresponden a la categoría funcional del objeto y con ello un balance entre la narrativa de valoración objetiva y subjetiva de la forma).

10. (en relación con el diseño ofrece los principios de la experiencia estética para comprender el vínculo entre determinadas composiciones y preferencias con respuesta emocional, permite el contraste de aspectos objetivos y subjetivos para la valoración de la apariencia y el aparecer del objeto).

11. (como fenómeno espacio temporalmente localizado, contexto y diseño tienen una correlación existencial que les configura mutuamente; el pensamiento y acto del Diseño con sentido estético se forma y es vertido en un ciclo iterativo de intercambio mental, físico y sensible con las personas, la materialidad e ideologías que suceden en un momento histórico, los diseñadores inmersos en su campo de operación abstraen e internalizan práctica y teoría en su historia personal para ofrecer codificaciones que conecten con ese contexto de praxis)

12. (permite ahondar en el valor de la performatividad del diseño, en la fuerza expresiva de la metáfora, la adjetivación, las narrativas como soporte a la creación de un concepto que es el que otorga carácter de referencia y de una construcción única y singular o autorreferente).

13. En Psicología, el término afecto refiere al proceso activo de experimentar una emoción intensa frente a un estímulo psico-físico. Como reacción instintiva tiene diferentes manifestaciones que van del llanto a la euforia. En tanto afecto, es una forma de filiación con personas, memorias, lugares, espacios o cosas que tienen resonancia emocional. El afecto sucede de manera involuntaria y se vincula a la memoria filogenética y ontogenética de los individuos. Hurley (2010).

14. Gui Bonsiepe, (1993). Del objeto a la interfase. Buenos Aires: Infinito.

15. Dan Berlyne (1971) acuña el término de revitalización de la estética psicológica como una proposición de una serie de variables estéticas entre las cuales la novedad y el contraste operan por comparación con otras propiedades para activar la atención.

16. Adela Cortina en su obra ¿Para qué sirve la Ética? (2013) trata la ética como una construcción humana a lo largo de su historia como un conjunto de valores que forjan un carácter de intersubjetividad y de manejo de la emocionalidad que está atravesada por el reconocimiento del otro, del entendimiento del porqué de una norma o valor que habilita al individuo para compartir los espacios vitales desde el respeto mutuo y de una manera colaborativa y no de segregación.

17. La dicotomía derivada del griego dichotomía refiere a la división de algo en partes iguales. Se compone del prefijo "dis" que indica dos, el verbo "temnein" que indica cortar y el sufijo "ía” que impone cualidad. Interpretada como la división de un concepto en dos partes complementarias separadas como opuestos. Ferdinand Saussure elabora la teoría de la dicotomía en el marco de la lingüística en donde estipula el lenguaje como un sistema en el que cada una de sus partes tiene valor al ser parte de una oposición de las otras partes otorgando así sentido, al menos en una mínima diferencia.

18. James Truslow Adams 1931 American Dream: "life [made] better and richer and fuller for everyone, with opportunity for each according to ability or achievement, regardless 
of social class or circumstances of birth." Pennsylvania Historic Vehicle Association of America, (2013).

19. Cultura es la trama de objetos e ideas que comunican significados a un determinado grupo de personas.

20. "Esencia intencional del objeto" expresión acuñada por Husserl en La intencionalidad: entre Husserl y la filosofía de la mente contemporánea. Jorba, M. (2011). Investigaciones Fenomenológicas, n. 8, 2011.pp. 77-78.

21. God Bless America frase acuñada en la canción compuesta por Irving Berlin durante la Primera Guerra Mundial en 1918, y revisada por el mismo en 1938 en tiempos de la Segunda Guerra Mundial toma fuerza en la ideología estadounidense en la Segunda Posguerra Mundial a partir de los 50s y se instala como creencia de la sociedad.

22. En la publicación General Motors Engineering Journal de 1957, reportan que el 70\% de las ventas de autos son influenciadas por las mujeres, sus reacciones impulsan el color, riqueza del detalle, calidad de las superficies y las líneas oblongas y aerodinámicas.

23. En Mayer, P. (1980). Diseño Industrial Raymond Loewy. P. 32. Barcelona: Blume.

24. MAYA (Most Advanced Yet Acceptable) Loewy, R. En Silvestre, 2016. Loewy Raymond. Never leave well enough alone. Simon \& Schuster: New York, 1951, pp. 220 -221.

25. The New York Times 1956 "Dreamers in Chief".

26. George Walker (1962). Popular Mechanics. The Automobile and Culture, p.47. En Gartman (1994) p. 153.

27. Show tomado directamente de la denominación en inglés que va más allá de exhibición a una presentación de expresiones artísticas tanto en los automóviles como en las del evento: musicales, circenses, danza y comparsas (Temple, 2015).

28. Relato o narrativa del Concept car es denominada Design theme - aesthetic character of the Concept car. Fuente: GM Design Files (1952).

29. Persuasión: en el pensamiento aristoteliano, se trata inicialmente de la articulación de objetivos del orador con el tiempo, el lugar y las circunstancias de la audiencia, luego, su combinación armoniosa con la expresión y el tema, la forma y el contenido con la voluntad de agradar, seducir y o convencer.

30. Con habilidad proyectual referimos a un conjunto de cualidades que dotan al diseñador para desarrollar su pensamiento y acto proyectual, a saber: reflexividad, imaginación y agencia. Como proyecto entenderemos el repertorio de operaciones y de información producida en adecuación a la intención del diseño, para el caso, la estética del objeto.

31. Conocimiento tácito es un conocimiento subjetivo, basado en la experiencia posee paradigmas, esquemas mentales, habilidades. Es tácito en la medida que se adquiere intuitiva e inconscientemente, no siempre puede ser explícito por quien lo posee y lo introyecta de manera subjetiva (Polanyi, 1967).

32. La cita corresponde a la traducción de Manuel García Morente en Patricio Lepe Carrión (2009, pp. 2-7).

33. Intuición de la palabra alemana Anschauung, significa visión, hace referencia a la impresión captada por los sentidos. Adán Sus, (2016) Categorías, intuiciones y espacio-tiempo kantiano. Revista de Humanidades de Valparaíso Año 4, 2016, 2do semestre, $\mathrm{N}^{\circ} 8$ "Kant, al principio de la Estética Trascendental, la intuición es el modo por el cual el conocimiento se refiere a objetos inmediatamente. La intuición caracteriza la presencia de la 
representación y tiene los rasgos de lo singular, lo dado aquí y ahora. Frente a esto, el concepto es la parte mediata de la referencia a objetos, la representación universal” (p. 226). 34. Significados operacionales: variables de cualificación para la composición semántica. En Krippendorf (1987a) Helga Lannoch y Hans-Jürgen Lannoch, "Vom geometrischen zum semantischen Raum" Form, pp.12-17.

35. Campo intelectual de Bourdieu en el ensayo "Campo intelectual y proyecto creador" (1967) en Amann (2015).

36. En Styling the Motor Car 1949. Heritage Center files. M.youtube.com/watch?v=rfBd6 GJ62ak.

37. En Styling the Motor Car 1949. Heritage Center files. M.youtube.com/watch?v=rfB d6GJ62ak.

38. Harley Earl y Nuccio Bertone (1957) evento Futuramic Styling, Futuramic Driving, Imagination in motion.

39. Friction (Fricción en inglés) es una metáfora utilizada por los diseñadores de la GM para indicar el juego de contrastes entre línea, color, textura y elementos compositivos como luces, rejillas, guardabarros y parachoques como recurso para llamar la atención (vivificar el ánimo del espectador en el sentido Kantiano).

40. Norman James en su libro Of Firebirds and Moonmen p. 52. Fuente de análisis de la historia de Concept cars.

41. McLean, R. y Habsburg (1959). General Motors Styling Staff, Firebird III General Arrangement and body design (pp. 1-2).

42. "The requirements of creative automotive styling are almost as numerous as they are demanding. Truly successful automotive styling, then must be pleasing to the creator, gratifying to the engineer, and inspiring to the motorist, a rare and magic meeting beauty, practicality, and popularity" Harley Earl, 1954 Cadillac sales brochure.

43. En el planteo de Beatriz Amann en su libro La crítica poética como instrumento de proyecto arquitectónico (2015) la interacción poética, reemplaza la noción de comparaciones binarias de los elementos de arquitectura como una metodología de análisis a la obra propuesta para encontrar en la interacción de los elementos compositivos, fricciones que se opongan a la necesidad de coherencia y correspondencias que requiere el carácter poético de la obra; es decir su esencia, especificidad, sentido y consistencia como proyecto. Sobre las comparaciones la autora aclara que “(...) se hacen en una doble dirección $-\mathrm{o}$, mejor dicho, sentido-A-B/B-A" (p. 119).

44. "To be successful, a stylist must always keep pace with the progress" Earl, 1950 en GM Media Archive.

45. "Laboratory on wheels" denominación propia de General Motors Corporation Internal.

46. "This is the car of the future only in the sense that some of its design or mechanical features may appear someday in standard motorcars" General Motors Corporation Internal communication December 29, 1950. Detroit.

47. "You should have brought a car you could race" expresión conceptual del Corvair, 1963. GM Media Archive.

48. Super Spyder 1963. Design Files Heritage Center y Artículo de Bryan Silvestro (2018) Here's Why Convertibles are called Spiders. 
49. Psicología del color. Joaquim Viñolas en su libro Diseño Ecológico 2005, desarrolla el apartado de diseño y color.

50. Escape, expresión mencionada en el Capítulo del Pensamiento Estético. Gartman (2004) analiza la estética del automóvil como un fenómeno que facultó el escape de los poseedores del automóvil de las condiciones de trabajo, relaciones sociales y otras tensiones propias de la posguerra; así que tiene un sentido físico de salida del medio y uno psicológico que ubica a la persona en otra condición.

51. En Krippendorff, K. (2006b). The Semantic Turn. Boca Ratón: Taylor \& Francis Group.

52. Pieza de la Chevrolet Corvette división. General Motors Corporation (1960).

53. Color rojo, asociado al amor divino, buena suerte, fiesta, felicidad, éxito; denota además la pasión humana. En Psicología vitalidad, poder, sexualidad, agresividad, peligro y plenitud (Viñolas, 2005, p. 229).

54. "A car Born for the Space Age" "Our attempt was to envision the car a person might drive to the launching site of a rocket to the moon" The Detroit News Pictorial Magazine, September 14 of 1958 .

\section{Referencias}

Adorno, T. (1980). Teoría Estética. Madrid: Taurus.

Althusser, L. (1971). Lenin and Philosophy, and Other Essays. London: New Left Books. Recuperado de https://www.alianz.com/.(2010).

Amann, B. (2015) La Crítica Poética como Instrumento del Proyecto Arquitectónico. 1a. Edición. Buenos Aires: Diseño, 2015.

Barthes, R. (1994 b). La Muerte del Autor. Barcelona: Paidós.

Baudrillard, J. (1987). América. Barcelona: Editorial Anagrama.

Benjamin, W. (1973) "La obra del arte en la época de la reproductibilidad técnica", en Benjamin, W. Discursos interrumpidos I. Madrid, Taurus, 1987.

Blijlevens, J., Hekkert, P., Helmut, L., Thurgood, Chen, L., C., Whitfield, T. (2017). The Aesthetic Pleasure in Design Scale: The Development of a Scale to Measure Aesthetic Pleasure for Designed Artifacts. American Psychological Association, 11(1), 86-98.

Bonsiepe, G. (1993). Del objeto a la interfase. Buenos Aires: Infinito.

Borja de Mozota, B. (2003). Design Management. New York: Allworth Press.

Bourdieu, P. (1979). La Distinción: Criterio y Bases Sociales del Gusto. (Ed. Carmen Ruiz de Elvira, 2002). (pp. 97-113, 225-229) México: Taurus.

Bourdieu, P. (1984). Distinction: A Social critique of the Jugdement of taste. Cambridge, MA: Harvard University Press.

Bourdieu, P. (2010). El Sentido Social del Gusto. Elementos para una Sociología de la Cultura. Buenos Aires: Siglo XXI editores, Argentina.

Bourdieu, P. (2013). Las Estrategias de la Reproducción Social. Buenos Aires: Siglo XXI editores, Argentina. 
Brandt, P. (2014). Meaning Production, Modelling Architecture and Blending en Niño, D. (et al). (2014) Ensayos semióticos II. Pp. 17-39. (1 a ed.). (Bogotá: Universidad de Bogotá Jorge Tadeo Lozano.

Bruner, J. (1988). Realidad Mental y Mundos Posibles. Los actos de la imaginación que dan sentido a la experiencia. Barcelona: Gedisa.

Breyer, G. (2007). Heurística del Diseño. Buenos Aires: Ediciones Fadu-Nobuko.

Bubner, R. (1989). "Uber einige Bedingungen gegenwártiger Aesthetik" en Oliveras, E. (2005). Estética. La Cuestión del Arte. P.189. Argentina: Ariel Filosofía.

Buchanan, R. (1995). Wicked Problems in Design Thinking. Cambridge: MIT Press.

Buchanan, R. and Doordan, D.; Margolin, V. (2010). The Designed World. Newyork: Berg Editorial.

Bürdek, B. (1994). Historia, teoría y práctica del diseño industrial. Las Funciones Estético-formales. En Y. Zimmermann (Ed.) (pp. 180-186). Barcelona: Editorial Gustavo Gili, S.A.

Castoriadis, C. (1994). Radical Imagination and the Social Instituting Imaginary. In Rethink Imagination: Culture and Creativity, edited by G. Robinson and J. Rundell, pp. 136 -154, London: Routledge

Castoriadis, C. (1999). La institución imaginaria de la sociedad. Buenos aires: Tusquets.

Casullo, N. (2015). Itinerarios de Modernidad. Corrientes del Pensamiento y Tradiciones Intelectuales desde la Ilustración Hasta la Posmodernidad. (p.9-21, 95-100, 105-108, 125-167). ( $1^{\text {a }}$ ed.). $5^{\text {a }}$ reimp. Buenos Aires: Eudeba.

Coates, D. (2003). Watches Tell More than Time. New York, Mc Graw Hill.

Cortina, A. (2013) ¿Para qué sirve la Ética? España: Paidós.

Crilly N., Moultrie J., Clarkson J. (2004) Seeing Things: Consumer response to The Visual in Product Design. Design Centre, Department of Engineering, University of Cambridge, UK. (pp.547 - 577).

Crouch, C. y Pearce, J. (2013). Doing Research in Design. Cap. I, II, III. Great Britain: Bloomsbry Academic.

Desmet, P., Hekkert, P. (2002). The basis of Product Emotions. Pleasure with Products Beyond Usability, (pp. 60-68). London: Taylor \& Francis.

Derrida, J. (1989) Firma, acontecimiento, contexto en Márgenes de la filosofía, Cátedra, Madrid.

Dewey, J. (2005). Art as an Experience. New York: Penguin. En Folkman, (2013) The Aesthetics of Imagination in Design. Cap. III y IV. Cambridge: MIT Press.

Dorfles, G. (1968). El Diseño Industrial y su Estética. Barcelona: Labor 1968.

Döring, S. (2010). Estética y Respuesta Emocional. pp. 53 -73. En Folkman, (2013) The Aesthetics of Imagination in Design. Cap. III y IV. Cambridge: MIT Press.

Drügh, Metz y Weyarnd. (2011). En The Aesthetics of Imagination Design. (p.27). Cambridge: IT Press books.

Eisenman, M. (2013). Understanding Aesthetic Innovation in the Context of Technological Evolution. Academy of Management, 38 (3), 332-351.

Frank, R. The lines of my Hand Photography of American Life (1989)

Friberg, C., (2013). Design and the Question of Aesthetics. Department of Communication, Aalborg University, Denmark. 
Folkmann, M. (2013). Aesthetics. En The MIT Press (Ed.). The Aesthetics of Imagination Design. (pp. 26-66). Cambridge: IT Press books.

Folkmann, M. (2015) The Role of Aesthetics for Design Phenomenology: The Sensual, Conceptual, and Contextual Framing of Experience BY Design. $11^{\text {Th }}$ European Academy of Design Conference.

Forsey, J. (2013). Aesthetics of Design. Oxford: Oxford University Press.

Flusser, V. Filosofía del Diseño. Madrid: Síntesis, 2002.

Fraenza, F. (2015). El Diseño del Sentido a la Acción. (1 a ed.). Córdoba: Brujas.

Gadamer, H. (1998a). Verdad y Método I: Retórica, Hermenéutica y Crítica de la Ideología. Comentarios Metacríticos a Verdad y Método I (1967). (pp. 225-265). www.esnips.com/ web/Linotipo.

Gadamer, H. (1998b). Verdad y Método II: Hermenéutica Clásica y Hermenéutica Filosófica (1977). (pp. 95-117). Ediciones Sígueme - Salamanca.

Gartman, D. (1994) Auto Opium: A Social History of American Automobile Design. New York: Routledge.

Genette, G. (1999). The Aesthetic Relation. New York: Cornell University Press

Giddens, A. (1991). Modernity and Self-identity: Self and Society in the Late Modern Age. Stanford, CA: Stanford University Press.

Giucci, G. (2007). La vida cultural del automóvil: rutas de la modernidad. (pp.15-33, 79,83,

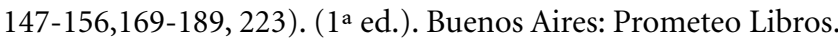

Habermas, J. (1981). The theory of communicative action. London: Beacon Press.

Haug, W. (1989). Publicidad y Consumismo. Crítica a la Estética Mercantil (pp. 93-127). México: Fondo de cultura económica.

Hekkert, P. (2006). Design aesthetics: principles of pleasure in design. Psychology Science, 48 (2), 157-172.

Hekkert, P. y Leder, H. (2007). Product Aesthetics en Psychology Science, Volume 48, pp.157 -172.

Herbert, S. (1996). The Sciences of the Artificial. Cambridge, MA: MIT Press.

Hurley, Erin. (2010). Theatre and Feeling. Houndmills: Palgrave.

Husserl, E. (1983). Ideas pertenecientes a una fenomenología pura y a una filosofía fenomenológica. Primer libro: Introducción general a una fenomenología pura. (Trans: Kersten, F.). La Haya, Boston, Lancaster:Martinus Nijhoff Editores

Husserl, E. (2007). Pensamiento y Fenomenología en Heurística del Diseño. Breyer, G.pp. 84-85. Argentina: Ediciones FADU y Nobuko, 2007.

Husserl (2016) en Zwier, J., Blok, V., Lemmens P., (2016) Phenomenology and the Empirical Turn: A Phenomenological Analysis of Postphenomenology. Philos. Technol. (2016) (29 (pp.313-333).

Ihde, D. (1990). Technology and the lifeworld: from garden to earth. Bloomington: Indiana University Press.

Ihde, D. (2012). Experimental phenomenology: Multistabilities (2nd ed.). Albany: SUNY Press.

Ihde, D. (2016) en Zwier, J., Blok, V., Lemmens P., (2016) Phenomenology and the Empirical Turn: A Phenomenological Analysis of Postphenomenology. Philos. Technol. (2016) (29 (pp.313-333). 
Iser, W. (2005). Rutas de la Interpretación. Fondo de Cultura Económica. Cap. III.

Jaafarnia, M. (2019). Evolution of Automobile Design. A brief introduction. Ghochan, Iran:Yadegar Omr Publication. (pp. 86-100).

Jagtap, S., Jagtap, S. (2015). Aesthetic Design process: Descriptive design research ways forward. In a Chakrabarti (Ed.), (Host publication title missing). Springer.

James, N. (2007). Of Firebirds \& Moonmen. A designer's story from the Golden Age. United States: Xlibris Corporation.

Jauss, H. (1967). "La historia literaria como desafío a la ciencia literaria”. En: Gumbrecht, H. U. (comp.) (1977), La actual ciencia literaria alemana. Salamanca, Anaya.

Jauss, H. (1977). Experiencia Estética y Hermenéutica Literaria. Traducción Jaime Siles y Ela M. Fernández-Palacios, Madrid: Taurus, 1986.

Jodard, P. (1992). Raymond Loewy. Most Advanced Yet Acceptable. London: Trefoil.

Jones, C. (1980). Métodos de Diseño. España: Gustavo Gili.

Kant, I. (2016 a). Kritik der Urteilskraft. Crítica del Discernimiento. Traducción de Roberto Aramayo y Salvador Mas. España: Machado libros.

Kant, I. (2006b) Crítica de la Razón Pura; Traducción Manuel G. Morente. Edición digital basada en la edición Madrid: Librería General de Victoriano Suárez, 1928. (www.cervantesvirtual.com).

Kant, I. (2008) Teoría y Praxis. Traducción de Carlos Correas. Buenos Aires: Leviatán, 2008.

Kester, G. (2004). Conversation Pieces. Community + Communication in Modern Art. Berkeley: University of California Press.

Knoedelseder, W. (2018). Fins. Harley Earl, the Rise of General Motors, and the Glory Days of Detroit. United States: Harper Business.

Krause, K. (1883). Compendio de Estética. (1a ed.). (pp.15- 103) de Pedro de Aullon de Haro, (1995) Madrid: Editorial Verbum.

Krippendorff, K. (1987). On the Essential Contexts of Artifacts or on The Proposition that "Design Is Making Sense (of Things)". En The Meaning of Products. Section II. (pp. 157-184). Pennsylvania: University of Pennsylvania.

Krippendorff, K. (2006). The Semantic Turn. Boca Ratón: Taylor \& Francis Group.

Krippendorff, K., Butter, R. (1984). Exploring the symbolic qualities of form, Innovation, 3(2), 4-9.

Lakoff, G. y Johnson, M. (1980). Metaphors We Live By. Chicago, IL: University of Chicago Press.

Langer, S. (1966). La influencia social del diseño en ¿Quién diseña a Estados Unidos? (pp. 197-214). Buenos Aires: Ediciones Infinito.

Latham, R. (1964). El artefacto como cifra cultural ¿Quién diseña a Estados Unidos? (pp. 29-39). Buenos Aires: Ediciones Infinito.

Leder y otros (2004). A Model of Aesthetic Appreciation and Aesthetic Judgments. London: The British Psychological Society.

Lemcke, C. (1945). Estética. Concepto y Esencia de la Estética. (pp. 13-184). Argentina: Biblioteca Nueva.

Loewy, R. Diseño Industrial Raymond Loewy. P.32. de Mayer, P. Barcelona: Blume.

Margolin y Buchanan. (1995). The Idea of Design. (pp.3-28, 70-74, 89-112). Cambridge: Massachussetts Institute of Technology. 
Merleau - Ponty, (1945). Fenomenología de la Percepción en Folkman (2015) The Role of Aesthetics for Design Phenomenology: The Sensual, Conceptual, and Contextual Framing of Experience by Design. 11Th European Academy of Design Conference. (EAD 11) (pp. 1-7).

Morcillo, L. (2013). La Estética del Bólido. (1 a ed.). Madrid: Afanias Industrias Gráficas. http://www.miguelmoro.net/wp-content/uploads/2012/09/publicidad-y-consumo.pdf Munari, B. (2016) Diseño y Comunicación visual. Última edición. Barcelona: Gustavo Gili. Mukařovský, J. (2014). Between Intentionality and Affect: on Jan Mukařovský's Theory of Reception. En Meerzon, Y. (2014) Otawa: Theatralia (2) $24-40$.

Mukařovský, J. (1970). Aesthetic Function, Norm and Value. Trans. Mark E Suino. Ann Arbor: Michigan Slavic Contributions.

Mukařovský, J. (1978) Intentionality and Unintentionality in Art. In Meerzon, Y Between Intentionality and Affect: on Jan Mukařovský Theory of Reception (2014).

Muratovski, G. (2016). Research for Designers. A Guide to Methods and Practice. London: Sage.

Nietzsche, F. (2010) El Origen de la Tragedia. Traducción. Madrid: Espasa, Calpe (2000). en Seel (2010) Estética del Aparecer. Buenos Aires: Katz editores.

Niño, D. (et al). (2008) Ensayos semióticos I. (1a ed.). (Bogotá: Universidad de Bogotá Jorge Tadeo Lozano.

Niño, D. (et al). (2014) Ensayos semióticos II. (1ª ed.). (Bogotá: Universidad de Bogotá Jorge Tadeo Lozano.

Norman, D. (2004). Emotional Design. The Design of Everyday Things. New York: Books.

Norman, D. (2010). Why Education Must Change. Core 77. researchgate.net.

Norman, J. (2007). Of Firebirds \& Moonmen. A Designer's Story from The Golden Age. Estados Unidos: Xlibris.

Oliveras, E. (2005). Estética. La Cuestión del Arte. Argentina: Ariel Filosofía.

Patrick, V. M., \& Hagtvedt, H. (2011). Aesthetic Incongruity Resolution. Journal of Marketing Research (JMR), 48(2), 393-402.

Pokropek, J. (2015). La Espacialidad Arquitectónica. Introducción a sus lógicas proyectuales para una morfología de las promenades. Buenos Aires: Bibliográfica de Voros S.A.

Rae, J. (1965) The American Automobile. A Brief History. (pp. 1-17, 18-51,87-105, 161164,247-253). (1 1 $^{\mathrm{e}}$ ed.). Buenos Aires: Prometeo libros.

Rees, C. (1999). Concept Cars. An A - Z guide to the world's most fabulous futuristic cars. London: Barnes and Nobles.

Ricoeur, P. (1977). Hermenéutica y Acción. De la Hermenéutica del Texto a la Hermenéutica de la Acción. (pp. 80-99). ( $1^{\text {a }}$ ed.). Buenos Aires: Prometeo libros.

Ricoeur, P. (1999). Ideología y Utopía. Barcelona: Gedisa.

Robert Frank (1989). The lines of my Hand Photography of American Life. USA: Robert Frank Ed.

Rosset, C. (2015). Lo Real y su Doble. Ensayo Sobre la Ilusión. (1 $1^{\text {a }}$ ed.). Buenos Aires: Libros del Zorzal.

Rutledge, P. (2011). Stories and Storytellers. Recuperado de: https://www.psychologytoday. com/us/blog/positively-media/201012/15-techno-cultural-trends-2011. 
Saussure, S. (1857 - 1913). Forma y substancia de la Expresión en el Conjunto de una Teoría del Lenguaje pp.7 -23. En Malmberg. B. (1989) - Revista española de lingüística, España: dialnet.unirioja.es.

Samaja, J. (2004). Epistemología y Metodología: elementos para una teoría de la investigación científica. Parte III. $3^{\circ}$ edic. $4^{\circ}$ reimp. Buenos Aires: Editorial Universitaria de Buenos Aires. Recuperado de: https://metodologiadelainvestigacionuader.files.wordpress. com/2016/06/epistemologia-y-metodologia-iii-samaja.pdf.

Samaja, J. (2008) en Ynoub, R. (2015) Cuestión de Método. Aportes a una metodología crítica. Cap. VIII.México: Cengage Learning.

Saussure, F. (2011). As dicotomias saussureanas e suas implicações sobre Os estudos linguísticosThe saussurean dichotomies and their implications For language studies. Revista de Educação, Linguagem e Literatura da UEG-Inhumas V. 3 No.2-outubro de 2011 -(pp. 38-55) Recuperado de: www.ueg.inhumas.com/revelli.

Scott, G.F. (2016) Why Design Matters. (cover story). Canadian Business, 89(4), 39-40.

Seel, M. (2010). Estética del aparecer. (1 a ed.). (Cap. 2 , 3 y 4). Madrid: Katz editores.

Selle, G. (1973). Ideología y Utopía del Diseño. Madrid: Gustavo Gili.

Silvestre, F. (2016). Pioneros del diseño: transformación y adaptabilidad de los diseñadores estadounidenses ( $1^{\text {a }}$ ed.). Buenos Aires: Bibliográfika de Voros S.A.

Schön, D.A. (1989). The reflective practitioner. how professionals think in action. Aldrshot: Ashgate Publishing Limited.

Simon, H. The Sciences of the Artificial (1981), (p.29). Cambridge: MA: MIT Press.

Simondon, G. (2016) Sobre la Filosofía (1950 -1988). Buenos Aires: Editorial Cactus. (pp. 27-68). (1 $1^{\text {a }}$ ed.).

Sparke, P. (2015). Diseño y cultura una introducción. De la traducción de María Jesús Rivas. ( $1^{\text {a }}$ ed.). ( $3^{\text {a }}$ tirada). Barcelona: Editorial Gustavo Gili.

Sudjic, D. (2009). El Lenguaje de Las Cosas. (pp. 9-49). Madrid: Turner España.

Temple, D. (2015). Motorama. GM's Legendary Show and Concept cars. New York: Car Tech, Inc.

Thompson, D. (2017). What makes things cool. Atlantic, 319 (1), 68-72.

Truslow, J. (1931) American Dream Life. Pennsylvania: Historic Vehicle Association (2013). Veblen, T. (1931). En Krippendorff, K. (2006 b). The Semantic Turn. Boca Ratón: Taylor $\&$ Francis Group.

Verbeek, P. (2005). Fenomenología de la Percepción en Folkman (2015b) The Role of Aesthetics for Design Phenomenology: The Sensual, Conceptual, and Contextual Framing of Experience by Design. 11Th European Academy of Design Conference. (EAD 11) (pp. 1-7).

Viñolas, J. (2005). Diseño Ecológico. Barcelona: Blume, 319 (1), 206-234.

Woodward, I. (2007) Understanding Material Culture. London: SAGE.

Wu Tyan - Yu, Tsao Chueh y Sie Cian - Yu (2017). Unity enhances product aesthetics and emotion. Recuperado de: https://www.researchgate.net/publication/315932705_Unity_enhances_product_aesthetics_and_emotion.

Zátonyi, M. (2011). Arte y creación: los caminos de la estética (2a ed.). Buenos Aires: Capital Intelectual S.A.

Zátonyi, M. (2002). Una Estética del arte y el diseño de imagen y sonido (5 ed.). Buenos Aires: Técnica CP-67. 
Zátonyi, M. (2016). Aportes a la Estética (2a ed.). Buenos Aires: La marca editora.

Žižek, S. El sublime objeto de la ideología, Siglo XXI, 2a ed., México, 2001 (1ª ed., 1992).

Zwier, J., Blok, V., Lemmens P., (2016) Phenomenology and the Empirical Turn: A Phenomenological Analysis of Postphenomenology. Philos. Technol. (2016) (29) (pp.313-333).

\section{Bibliografía}

\section{Fuentes Primarias}

American Battle for Abundance GM Vision disponible en https://www.gmheritagecenter. com/gm-heritage-archive/Consumer_Information/American_Battle_For_Abundance. html Accesado 12,13,18 de Noviembre 2018. 24,25,27 de Agosto 2019.

Automobile and American Culture - 1950s / 1960s disponible desde Culture in America disponible desde https://thestudioscoop.com/2012/06/18/the-car-peoples-fascinationwith-the-machine-car-culture-in-america-in-1950s-part-6/ Accesado en 3,4,5, de Octubre de 2019 y 22, 24, 26 de Mayo de 2020

Curtice, Harlow, to GM Motorama Press Conference, at the GM Challenge Ahead Luncheon, 19 January 1954, New York City, New York.

Donner, Frederic, to GM Motorama Press Conference, at the Dealer Annual Meeting, 15 October 1958, New York City, New York.

Donner, Frederic, to Metro Mobility Press Conference, at Metro Mobility - Dreams Come True, October 1963, Detroit, Michigan, USA.

Earl, Harley, to Inter-organization letters only, Styling Division, Field where designers operate. Concept car Le Sabre Project. 16 January 1953, New York General Motors Corporation, New York City.

Earl, Harley, to Inter-organization letters only, Styling Division, Styling and Features Concept car Cadillac Project. 12 March 1958, New York General Motors Corporation, New York City.

Garrett, Paul, to GM Motorama Press Conference, at the Press Conference Luncheon, 18 January 1955, New York City, New York.

Garrett, Paul, to GM Motorama Press Conference, at the Press Conference Luncheon, 14 January 1955, New York City, New York.

Garrett, Paul, to GM Motorama Press Conference, at the Press Conference Luncheon, 14 January 1957, New York City, New York.

General Motors Styling to Afternoon Newspapers, 29 December 1950, New York General Motors Corporation, New York City.

General Motors Styling to styling staff, 12 January 1955, New York General Motors Corporation, New York City.

General Motors, An "Experimental Laboratory on Wheels". Cadillac Series, 1959, Styling Division, Detroit, Michigan, USA.

General Motors, An “Experimental Laboratory on Wheels”. Le Sabre, 1952, Styling Division, Detroit, Michigan, USA. 
General Motors, An Innovation Plan. Cars and Kitchens of Tomorrow. Color and surfaces challenges, 1955, Styling Division, Detroit, Michigan, USA.

General Motors, Imagination in Motion. Firebird III, 1962, Seattle World's Fair

General Motors, Imagination in Motion. Firebird III, 1962, Seattle World's Fair

General Motors, Let's go to the Fair and Futurama at New York's Fair. Firebird III, 1962, Seattle World's Fair.

GM Motorama Press Conference, at the New York World's Fair, 9 January 1960, New York City, New York.

GM Motorama Press Conference, at the New York World's Fair, 8 January 1963, New York City, New York.

GM The First 75 years of Transportation Products. Styling Sets. Concept cars. 4 July 1983, Detroit, Michigan, USA.

Historical Archive General Motors Heritage Center disponible desde https://www.gmherita gecenter.com/ Accesado entre 14 de Junio 2019 y 13 de Julio 2019.

How Automobile shaped America - 1950s / 1960s https://www.historicvehicle.org/ how-the-automobile-shaped-america-the-burbs/ Accesado 11, 12, 13 de Noviembre de 2019. 22, 23, 24 de Abril de 2020.

"I dream Automobiles by Harley Earl” The Saturday Evening Post-Int September 1954.

Mitchell, W. L., to Inter-organization letters only, 2 December 1957, New York General Motors Corporation, New York City.

Small Size - A Must, “The European Cars” September 8 of 1954, Technical editor / The Motor for the European Pocket Book.

\section{Fuentes Secundarias}

Abidin, S.; Warrell, A., A y Liem (2011). The Significance of Form Elements: A Study Of Representational Content Of Design Sketches. Desirer 11 Netherlands. (1) 21-28.

Adorno, T. (1980) [1970]. Teoría Estética. Madrid: Taurus

Al - Zaher, A., El Maraghy W., Pasek Z.J. (2011) Enabling Car Body Customization through Automotive Framing Systems Design. University of Windsor. Ontario N9B 3P4. CA. Recuperado de: https://www.academia.edu/20570662/Design_of_reconfigurable_auto motive_framing_system.

Althusser, L. (1971). Lenin and Philosophy, and Other Essays. London: New Left Books. Recuperado de https://www.alianz.com/.(2010).

Amann, B. (2015) La Crítica Poética como Instrumento del Proyecto Arquitectónico. 1a Edición. Buenos Aires: Diseño, 2015.

Anderson, I.F. (marzo, 2011). Semiomática. Fundamentos para el Desarrollo de Indicadores Estético-Semiológicos Aplicables a la Medición de "Lo-Bello" y "Lo Útil” Sustentado en la Base de un Modelo Matemático (Comunicación). Actas de Diseño, Año V, Vol.10, En proceso de evaluación, (ISSN: 1850-2032), Universidad de Palermo, Buenos Aires, Argentina.

Aparicio, J. (2008). Construir con la Razón y los Sentidos. Reflexiones docentes y de investigación. Buenos Aires: Nobuko. 
Arregui, J. (1992). Francis Hutcheson. Una Investigación Sobre el Origen de Nuestra Idea de Belleza. Madrid: Editorial Tecnos.

Austin, J. (1998). Cómo hacer cosas con las palabras, Paidós, Barcelona

Barthes, R. (1970). Mitologías. (2a ed.). 1ª reimpresión. Buenos Aires: Siglo Veintiuno: 2010.

Barthes, R. (1994 b). La Muerte del Autor. Barcelona: Paidós.

Bates, D y Plog, F. (1976). Cultural Anthropology (3rd ed.). New York: MC Graw-Hill.

Baudrillard, J. (1987). América. Barcelona: Editorial Anagrama.

Baumgarten, A. (1750 -1758). Aesthetica. En Oliveras, E. (2004). Estética. Baumgarten pp. 23-24, 26-28,30,40,47, 170,371. Argentina: Producciones Gráficas Spurr 653, Avellaneda.

Beadle, T. (2000) Automóviles Americanos. 1919 - 1974. Madrid: Susaeta en Morcillo, L. (2013) La Estética del Bólido. España: Afanías Industrias gráficas.

Benedikt, S., Stokburger-Sauer, N. (2016). The Effect of Stylistic Product Information on Consumers' Aesthetic Responses. Psychology \& Marketing, 33(3), 165-176.

Benjamin, W. (1973) "La obra del arte en la época de la reproductibilidad técnica", en Benjamin, W. Discursos interrumpidos I. Madrid, Taurus, 1987.

Berger, J. (2000). Modos de Ver. Barcelona: Gustavo Gili.

Blijlevens, J., Hekkert, P., Helmut, L., Thurgood, Chen, L., C., Whitfield, T. (2017). The Aesthetic Pleasure in Design Scale: The Development of a Scale to Measure Aesthetic Pleasure for Designed Artifacts. American Psychological Association, 11(1), 86-98.

Bonsiepe, G. (1993). Del objeto a la interfase. Buenos Aires: Infinito.

Borja de Mozota, B. (2003). Design Management. New York: Allworth Press.

Bourdieu, P. (1979). La Distinción: Criterio y Bases Sociales del Gusto. (Ed. Carmen Ruiz de Elvira, 2002). (pp. 97-113, 225-229) México: Taurus.

Bourdieu, P. (1984). Distinction: A Social critique of the Jugdement of taste. Cambridge, MA: Harvard University Press.

Bourdieu, P. (1990). The Logic of Practice. Palo Alto, Ca: Stanford University Press.

Bourdieu, P. (2010). El Sentido Social del Gusto. Elementos para una Sociología de la Cultura. Buenos Aires: Siglo XXI editores, Argentina.

Bourdieu, P. (2013). Las Estrategias de la Reproducción Social. Buenos Aires: Siglo XXI editores, Argentina.

Brandt, P. (2014). Meaning Production, Modelling Architecture and Blending en Niño, D. (et al). (2014) Ensayos semióticos II. Pp. 17-39. (1 1 ed.). (Bogotá: Universidad de Bogotá Jorge Tadeo Lozano.

Bruner, J. (1988). Realidad Mental y Mundos Posibles. Los actos de la imaginación que dan sentido a la experiencia. Barcelona: Gedisa.

Breyer, G. (2007). Heurística del Diseño. Buenos Aires: Ediciones Fadu-Nobuko.

Bubner, R. (1989). "Uber einige Bedingungen gegenwártiger Aesthetik" en Oliveras, E. (2005). Estética. La Cuestión del Arte. P.189. Argentina: Ariel Filosofía.

Buchanan, R. (1995). Wicked Problems in Design Thinking. Cambridge: MIT Press.

Buchanan, R. and Doordan, D.; Margolin, V. (2010). The Designed World. Newyork: Berg Editorial.

Bürdek, B. (1994). Historia, teoría y práctica del diseño industrial. Las Funciones Estético-formales. En Y. Zimmermann (Ed.) (pp. 180-186). Barcelona: Editorial Gustavo Gili, S.A. 
Butler, J. (2002). Cuerpos que importan / Sobre los límites materiales y discursivos del "sexo". Buenos Aires: Paidós.

Catalano, Ch., Meirana M., Papaleo L., (2000) Structured Modeling for Aesthetic Design. Istituto per la Matematica Applicata - Consiglio Nazionale delle Ricerche.

Castoriadis, C. (1994). Radical Imagination and the Social Instituting Imaginary. In Rethink Imagination: Culture and Creativity, edited by G. Robinson and J. Rundell, pp. 136 -154, London: Routledge

Castoriadis, C. (1999). La institución imaginaria de la sociedad. Buenos aires: Tusquets.

Catoggio, L. (2011). La Estructura Hermenéutica de los Sistemas Vivos y los Artefactos Técnicos. Revista Iberoamericana de Ciencia, Tecnología y Sociedad, 19(7), 123-129.

Casullo, N. (2015). Itinerarios de Modernidad. Corrientes del Pensamiento y Tradiciones Intelectuales desde la Ilustración Hasta la Posmodernidad. (p.9-21, 95-100, 105-108, 125-167). ( $1^{\text {a }}$ ed.). $5^{\text {a }}$ reimp. Buenos Aires: Eudeba.

Coates, D. (2003). Watches Tell More than Time. New York, Mc Graw Hill.

Cortina, A. (2013) ¿Para qué sirve la Ética? España: Paidós.

Crilly N., Moultrie J., Clarkson J. (2004) Seeing Things: Consumer response to The Visual in Product Design. Design Centre, Department of Engineering, University of Cambridge, UK. (pp.547 - 577).

Crouch, C. y Pearce, J. (2013). Doing Research in Design. Cap. I, II, III. Great Britain: Bloomsbry Academic.

Demir, E. (2008). The Field of Design and Emotion: Concepts, Arguments, Tools, and Current Issues. METU JFA, 25(1) 135-152.

Desmet, P., Hekkert, P. (2002). The basis of Product Emotions. Pleasure with Products Beyond Usability, (pp. 60-68). London: Taylor \& Francis.

Derrida, J. (1989) Firma, acontecimiento, contexto en Márgenes de la filosofía, Cátedra, Madrid.

Dewey, J. (2005). Art as an Experience. New York: Penguin. En Folkman, (2013) The Aesthetics of Imagination in Design. Cap. III y IV. Cambridge: MIT Press.

Dorfles, G. (1968). El Diseño Industrial y su Estética. Barcelona: Labor 1968.

Döring, S. (2010). Estética y Respuesta Emocional. pp. 53 -73. En Folkman, (2013) The Aesthetics of Imagination in Design. Cap. III y IV. Cambridge: MIT Press.

Dubberly, H. (2009). How Do You design? A Compendium of Models. (p.24). San Francisco: Dubberly Design Office.

Drügh, Metz y Weyarnd. (2011). En The Aesthetics of Imagination Design. (p.27). Cambridge: IT Press books.

Eisenman, M. (2013). Understanding Aesthetic Innovation in the Context of Technological Evolution. Academy of Management, 38 (3), 332-351.

Frank, R. The lines of my Hand Photography of American Life (1989)

Friberg, C., (2013). Design and the Question of Aesthetics. Department of Communication, Aalborg University, Denmark.

Folkmann, M. (2013). Aesthetics. En The MIT Press (Ed.). The Aesthetics of Imagination Design. (pp. 26-66). Cambridge: IT Press books. 
Folkmann, M. (2015) The Role of Aesthetics for Design Phenomenology: The Sensual, Conceptual, and Contextual Framing of Experience BY Design. $11^{\mathrm{Th}}$ European Academy of Design Conference.

Forsey, J. (2013). Aesthetics of Design. Oxford: Oxford University Press.

Flusser, V. Filosofía del Diseño. Madrid: Síntesis, 2002.

Fraenza, F. (2015). El Diseño del Sentido a la Acción. (1a ed.). Córdoba: Brujas.

Gadamer, H. (1998a). Verdad y Método I: Retórica, Hermenéutica y Crítica de la Ideología. Comentarios Metacríticos a Verdad y Método I (1967). (pp. 225-265). www.esnips.com/ web/Linotipo.

Gadamer, H. (1998b). Verdad y Método II: Hermenéutica Clásica y Hermenéutica Filosófica (1977). (pp. 95-117). Ediciones Sígueme - Salamanca.

García, N. (2004) Diferentes, desiguales y desconectados. La cultura extraviada en sus definiciones. Barcelona: Gedisa.

Gartman, D. (1994) Auto Opium: A Social History of American Automobile Design. New York: Routledge.

Gay, A. (2004) El Diseño Industrial en la Historia. (2a ed.). (pp.9-43,129-162). Córdoba: Ediciones Tec.

García, R. (2013). Sistemas Complejos. Conceptos, método y fundamentación epistemológica de la investigación interdisciplinaria. Barcelona: Gedisa.

Genette, G. (1999). The Aesthetic Relation. New York: Cornell University Press

Geertz, C. (1973). The Interpretation of Cultures. Harper Torchbooks (5043).

Greish, J. (2010). La Invención de la Diferencia Ontológica. Heidegger Después de Ser y Tiempo. Buenos Aires: Las Cuarenta Cap. II (126-148).

Giddens, A. (1991). Modernity and Self-identity: Self and Society in the Late Modern Age. Stanford, CA: Stanford University Press.

González, C. (2014). El Paradigma Moderno del Diseño Industrial y la Creación Artística. Grafía 11(2), 109-133.

Gorman, C. (2003). The Industrial Design Reader. (pp.144-186). New York: Allworth Press.

Grimson, A. (2011). Los límites de la Cultura Cap.5. Crítica de las teorías de la identidad. Buenos Aires: Siglo XXI editores.

Giucci, G. (2007). La vida cultural del automóvil: rutas de la modernidad. (pp.15-33, 79,83, 147-156,169-189, 223). (1 $1^{\text {a }}$ ed.). Buenos Aires: Prometeo Libros.

Goldstein, E. (2002). Sensation and perception, Sixth Edition Pacific Grove, CA: Wadswoth.

Guy, J. (2016). La Cultura del Diseño. De la traducción de Marcos Muslera. (1 $1^{\mathrm{a}}$ ed.). (4a tirada). Barcelona: Editorial Gustavo Gili.

Habermas, J. (1981). The theory of communicative action. London: Beacon Press.

Haug, W. (1989). Publicidad y Consumismo. Crítica a la Estética Mercantil (pp. 93-127). México: Fondo de cultura económica.

Heidegger, M. “El Origen de la Obra de Arte”, en Seel (2010) Estética del Aparecer. Buenos Aires: Katz editores.

Hekkert, P. (2006). Design aesthetics: principles of pleasure in design. Psychology Science, 48 (2), 157-172.

Hekkert, P. y Leder, H. (2007). Product Aesthetics en Psychology Science, Volume 48, pp.157 -172. 
Herbert, S. (1996). The Sciences of the Artificial. Cambridge, MA: MIT Press.

Hurley, Erin. (2010). Theatre and Feeling. Houndmills: Palgrave.

Husserl, E. (1983). Ideas pertenecientes a una fenomenología pura y a una filosofía fenomenológica. Primer libro: Introducción general a una fenomenología pura. (Trans: Kersten, F.). La Haya, Boston, Lancaster:Martinus Nijhoff Editores

Husserl, E. (2007). Pensamiento y Fenomenología en Heurística del Diseño. Breyer, G.pp. 84-85. Argentina: Ediciones FADU y Nobuko, 2007.

Husserl (2016) en Zwier, J., Blok, V., Lemmens P., (2016) Phenomenology and the Empirical Turn: A Phenomenological Analysis of Postphenomenology. Philos. Technol. (2016) (29 (pp.313-333).

Hustwit, G. (2010) Objectified. 'Poetic of Design'. Recuperado de https://kssarchitects.com/ intersections/blog/2010/12/inspiration-objectified-documentary-film-gary-hustwit.

Hutcheson, F. (1992). Una investigación sobre el origen de nuestra idea de belleza Editorial Tecnos.

Iazzetta, E. (2010). Placer, razón, imaginación o estética indeterminada en la comprensión de la experiencia socio estética. Argos 27(52), 126-149.

Ihde, D. (1990). Technology and the lifeworld: from garden to earth. Bloomington: Indiana University Press.

Ihde, D. (2012). Experimental phenomenology: Multistabilities (2nd ed.). Albany: SUNY Press. Ihde, D. (2016) en Zwier, J., Blok, V., Lemmens P., (2016) Phenomenology and the Empirical Turn: A Phenomenological Analysis of Postphenomenology. Philos. Technol. (2016) (29 (pp.313-333).

Iser, W. (2005). Rutas de la Interpretación. Fondo de Cultura Económica. Cap. III.

Jaafarnia, M. (2019). Evolution of Automobile Design. A brief introduction. Ghochan, Iran:Yadegar Omr Publication. (pp. 86-100).

Jagtap, S., Jagtap, S. (2015). Aesthetic Design process: Descriptive design research ways forward. In a Chakrabarti (Ed.), (Host publication title missing). Springer.

James, N. (2007). Of Firebirds \& Moonmen. A designer's story from the Golden Age. United States: Xlibris Corporation.

Jauss, H. (1967). "La historia literaria como desafío a la ciencia literaria”. En: Gumbrecht, H. U. (comp.) (1977), La actual ciencia literaria alemana. Salamanca, Anaya.

Jauss, H. (1977). Experiencia Estética y Hermenéutica Literaria. Traducción Jaime Siles y Ela M. Fernández-Palacios, Madrid: Taurus, 1986.

Jodard, P. (1992). Raymond Loewy. Most Advanced Yet Acceptable. London: Trefoil.

Jones, C. (1980). Métodos de Diseño. España: Gustavo Gili.

Julier, G. (2013). Cultura del Diseño. España: Gustavo Gili.

Kant, I. (2016 a). Kritik der Urteilskraft. Crítica del Discernimiento. Traducción de Roberto Aramayo y Salvador Mas. España: Machado libros.

Kant, I. (2006b) Crítica de la Razón Pura; Traducción Manuel G. Morente. Edición digital basada en la edición Madrid: Librería General de Victoriano Suárez, 1928. (www.cervantesvirtual.com).

Kant, I. (2008) Teoría y Praxis. Traducción de Carlos Correas. Buenos Aires: Leviatán, 2008.

Kemp, M. (2006). Leonardo. México: Fondo de Cultura Económica. (1ª ed.). (pp.159172-173). 
Kester, G. (2004). Conversation Pieces. Community + Communication in Modern Art. Berkeley: University of California Press.

Knoedelseder, W. (2018). Fins. Harley Earl, the Rise of General Motors, and the Glory Days of Detroit. United States: Harper Business.

Krause, K. (1883). Compendio de Estética. (1ª ed.). (pp.15-103) de Pedro de Aullon de Haro, (1995) Madrid: Editorial Verbum.

Krippendorff, K. (1987). On the Essential Contexts of Artifacts or on The Proposition that "Design Is Making Sense (of Things)". En The Meaning of Products. Section II. (pp. 157-184). Pennsylvania: University of Pennsylvania.

Krippendorff, K. (2006). The Semantic Turn. Boca Ratón: Taylor \& Francis Group.

Krippendorff, K., Butter, R. (1984). Exploring the symbolic qualities of form, Innovation, 3(2), 4-9.

Lakoff, G. y Johnson, M. (1980). Metaphors We Live By. Chicago, IL: University of Chicago Press.

Langer, S. (1966). La influencia social del diseño en ¿Quién diseña a Estados Unidos? (pp. 197-214). Buenos Aires: Ediciones Infinito.

Latham, R. (1964). El artefacto como cifra cultural ¿Quién diseña a Estados Unidos? (pp. 29-39). Buenos Aires: Ediciones Infinito.

Leder y otros (2004). A Model of Aesthetic Appreciation and Aesthetic Judgments. London: The British Psychological Society.

Lemcke, C. (1945). Estética. Concepto y Esencia de la Estética. (pp. 13-184). Argentina: Biblioteca Nueva.

Linton, R. (1945) Cultura y Personalidad. (3a ed.). (pp. 12-40) México: Fondo de cultura económica.

Lipovetsky, G. (2015) La era del vacío (13a ed.). (pp.105-119) Barcelona: Editorial Anagrama. Loewy, R. Diseño Industrial Raymond Loewy. P.32. de Mayer, P. Barcelona: Blume.

Maldonado, T. (1963). El Diseño Industrial Reconsiderado. Barcelona: Gustavo Gili.

Manzini, E. (2015). Design, When Everybody Designs. Cap. II, III. Cambridge: MIT Press.

Margolin y Buchanan. (1995). The Idea of Design. (pp.3-28, 70-74, 89-112). Cambridge: Massachussetts Institute of Technology.

Mayer y Landwehr (2017). Medidas Objetivas de Tipicidad del Diseño. Design Studies. 54. (pp. $146-161)$.

Meikle, J. (2005). Design in the USA, (pp.131-210), Oxford: Oxford University Press Oliveras, E. (2005). Estética La cuestión del Arte. ( $1^{\text {a }}$ ed.). Buenos Aires: Ariel.

Merleau - Ponty, (1945). Fenomenología de la Percepción en Folkman (2015) The Role of Aesthetics for Design Phenomenology: The Sensual, Conceptual, and Contextual Framing of Experience by Design. 11Th European Academy of Design Conference. (EAD 11) (pp. 1-7).

Mills, C. W. (2008). [1958] The man in the middle. The Designer. In J. H. Summers (1 ${ }^{\mathrm{a}}$ ed.). (pp. 173-183). The politics of truth: Selected writings of C. Wright Mills. New York: Oxford University Press.

Morcillo, L. (2013). La Estética del Bólido. (1 $1^{\text {a }}$ ed.). Madrid: Afanias Industrias Gráficas. http://www.miguelmoro.net/wp-content/uploads/2012/09/publicidad-y-consumo.pdf Munari, B. (2016) Diseño y Comunicación visual. Última edición. Barcelona: Gustavo Gili. 
Mukařovský, J. (2014). Between Intentionality and Affect: on Jan Mukařovský's Theory of Reception. En Meerzon, Y. (2014) Otawa: Theatralia (2) $24-40$.

Mukařovský, J. (1970). Aesthetic Function, Norm and Value. Trans. Mark E Suino. Ann Arbor: Michigan Slavic Contributions.

Mukařovský, J. (1978) Intentionality and Unintentionality in Art. In Meerzon, Y Between Intentionality and Affect: on Jan Mukařovský Theory of Reception (2014).

Muratovski, G. (2016). Research for Designers. A Guide to Methods and Practice. London: Sage.

Nietzsche, F. (2010) El Origen de la Tragedia. Traducción. Madrid: Espasa, Calpe (2000). en Seel (2010) Estética del Aparecer. Buenos Aires: Katz editores.

Niño, D. (et al). (2008) Ensayos semióticos I. (1ª ed.). (Bogotá: Universidad de Bogotá Jorge Tadeo Lozano.

Niño, D. (et al). (2014) Ensayos semióticos II. (1ª ed.). (Bogotá: Universidad de Bogotá Jorge Tadeo Lozano.

Norman, D. (2004). Emotional Design. The Design of Everyday Things. New York: Books.

Norman, D. (2010). Why Education Must Change. Core 77. researchgate.net.

Norman, J. (2007). Of Firebirds \& Moonmen. A Designer's Story from The Golden Age. Estados Unidos: Xlibris.

O’Leary. Z. (2004). The Essential Guide to Doing Research. (1 ${ }^{\text {a }}$ ed.). London: SAGE Publications Ltd.

Oliveras, E. (2005). Estética. La Cuestión del Arte. Argentina: Ariel Filosofía.

Patrick, V. M., \& Hagtvedt, H. (2011). Aesthetic Incongruity Resolution. Journal of Marketing Research (JMR), 48(2), 393-402.

Pokropek, J. (2015). La Espacialidad Arquitectónica. Introducción a sus lógicas proyectuales para una morfología de las promenades. Buenos Aires: Bibliográfica de Voros S.A.

Polanyi, M. (1967). The Tacit Dimension. USA: Anchor Books.

Pye, D. (1978). The Nature and Aesthetics of Design. (2a ed.). New York: Van Nostrand.

Rae, J. (1965) The American Automobile. A Brief History. (pp. 1-17, 18-51,87-105, 161164,247-253). (1 ${ }^{a}$ ed.). Buenos Aires: Prometeo libros.

Reber, S., Schwarz, N., Winkielman, P. (2004). Processing fluency and aesthetic pleasure: Is beauty in the perceiver's processing experience? Personality and Social Psychology Review, 4 Redesign, development and organizational learning. (1997). IN J.J. Boonstra, and K.M. Bennebroek Gravenhorst (Eds.), Barriers to organizational change and innovation. (EAWOP, 7-30. ed.), Leuven.

Rees, C. (1999). Concept Cars. An A - Z guide to the world's most fabulous futuristic cars. London: Barnes and Nobles.

Reinante, C. (2014) Morfología y espacio. Materiales para una comprensión epistemológica. Santa Fe: Ediciones UNL.

Riccini, R. (1996). History from Things: Notes on The History of Industrial Design. pp. 211 -227. En Buchanan, R. and Doordan, D.; Margolin, V. (2010). The Designed World. Newyork: Berg Editorial.

Ricoeur, P. (1977). Hermenéutica y Acción. De la Hermenéutica del Texto a la Hermenéutica de la Acción. (pp. 80-99). (1 $1^{\text {a }}$ ed.). Buenos Aires: Prometeo libros.

Ricoeur, P. (1999). Ideología y Utopía. Barcelona: Gedisa. 
Robert Frank (1989). The lines of my Hand Photography of American Life. USA: Robert Frank Ed.

Robert, V. (1995). The Place of Product Design and Aesthetics in Consumer Research. Advances in Consumer Research (22), 641-645.

Rosset, C. (2015). Lo Real y su Doble. Ensayo Sobre la Ilusión. ( $1^{\text {a ed. }}$.). Buenos Aires: Libros del Zorzal.

Roth, S. (1999). The State of Design Research. Design Issues:15 (2), 18-26 MIT.

Rothacker, E. (1957). Problemas de Antropología Cultural. México: Fondo de Cultura Económica I, III, VI, VIII.

Rutledge, P. (2011). Stories and Storytellers. Recuperado de: https://www.psychologytoday. com/us/blog/positively-media/201012/15-techno-cultural-trends-2011.

Sartre, J. (1940). Límaginaire. Paris: Gallimard en Folkman, M. (2013) The Aesthetics of Imagination in Design. Cambridge: MIT Press.

Saussure, S. (1857 - 1913). Forma y substancia de la Expresión en el Conjunto de una Teoría del Lenguaje pp.7 -23. En Malmberg. B. (1989) - Revista española de lingüística, España: dialnet.unirioja.es.

Samaja, J. (2004). Epistemología y Metodología: elementos para una teoría de la investigación científica. Parte III. $3^{\circ}$ edic. $4^{\circ}$ reimp. Buenos Aires: Editorial Universitaria de Buenos Aires. Recuperado de: https://metodologiadelainvestigacionuader.files.wordpress. com/2016/06/epistemologia-y-metodologia-iii-samaja.pdf.

Samaja, J. (2008) en Ynoub, R. (2015) Cuestión de Método. Aportes a una metodología crítica. Cap. VIII.México: Cengage Learning.

Saussure, F. (2011). As dicotomias saussureanas e suas implicações sobre Os estudos linguísticosThe saussurean dichotomies and their implications For language studies. Revista de Educação, Linguagem e Literatura da UEG-Inhumas V. 3 No.2-outubro de 2011 -(pp. 38-55) Recuperado de: www.ueg.inhumas.com/revelli.

Sautu, R. (2010) Manual de Metodología. Construcción del Marco Teórico, Formulación de los Objetivos y Elección de la Metodología. Buenos Aires: Prometeo.

Schlimgen, A. (2010). Categories and Schemata. Kant and the Critique of Pure Reason, translation on Cambridge University Press, 2008. Res Cogitans (1) 79-88.

Scott, G.F. (2016) Why Design Matters. (cover story). Canadian Business, 89(4), 39-40.

Seel, M. (2010). Estética del aparecer. (1ª ed.). (Cap. 2 , 3 y 4). Madrid: Katz editores.

Selle, G. (1973). Ideología y Utopía del Diseño. Madrid: Gustavo Gili.

Silvestre, F. (2016). Pioneros del diseño: transformación y adaptabilidad de los diseñadores estadounidenses ( $1^{\text {a }}$ ed.). Buenos Aires: Bibliográfika de Voros S.A.

Schön, D.A. (1989). The reflective practitioner. how professionals think in action. Aldrshot: Ashgate Publishing Limited.

Shopenhauer, A. (1983) El Mundo como Voluntad y Representación. Madrid: Edaf.

Skaggs, S. (2017). Fire Signs: A Semiotic Theory for Graphic Design. (pp. 1-25, 107-127, 203). (1 ${ }^{\text {a }}$ ed.). Cambridge: Massachusetts Institute of Technology.

Simon, H. The Sciences of the Artificial (1981), (p.29). Cambridge: MA: MIT Press.

Simondon, G. (2013) Imaginación e invención (1965-1966) (1 $1^{\mathrm{a}}$ ed.). Buenos Aires: Editorial Cactus. 
Simondon, G. (2016) Sobre la Filosofía (1950 -1988). Buenos Aires: Editorial Cactus. (pp. 27-68). (1 $1^{\text {a }}$ ed.).

Sparke, P. (2015). Diseño y cultura una introducción. De la traducción de María Jesús Rivas. ( $1^{\text {a }}$ ed.). ( $3^{\text {a }}$ tirada). Barcelona: Editorial Gustavo Gili.

Spillers, F. (2004). Emotion as a Cognitive Artifact and The Design Implications for Products That are Perceived as Pleasurable. Experience Dynamics, USA.

Strauss, L., Barthes, Moles y otros. (1991) El Análisis Estructural. Kitsch y Objeto (pp.117150). Buenos Aires: Centro Editor de América Latina S.A.

Sudjic, D. (2009). El Lenguaje de Las Cosas. (pp. 9-49). Madrid: Turner España.

Temple, D. (2015). Motorama. GM's Legendary Show and Concept cars. New York: Car Tech, Inc.

Thompson, D. (2017). What makes things cool. Atlantic, 319 (1), 68-72.

Truslow, J. (1931) American Dream Life. Pennsylvania: Historic Vehicle Association (2013). Veblen, T. (1931). En Krippendorff, K. (2006 b). The Semantic Turn. Boca Ratón: Taylor \& Francis Group.

Verbeek, P. (2005). Fenomenología de la Percepción en Folkman (2015b) The Role of Aesthetics for Design Phenomenology: The Sensual, Conceptual, and Contextual Framing of Experience by Design. 11Th European Academy of Design Conference. (EAD 11) (pp. 1-7).

Viñolas, J. (2005). Diseño Ecológico. Barcelona: Blume, 319 (1), 206-234.

Woodward, I. (2007) Understanding Material Culture. London: SAGE.

Wu Tyan - Yu, Tsao Chueh y Sie Cian - Yu (2017). Unity enhances product aesthetics and emotion. Recuperado de: https://www.researchgate.net/publication/315932705_Unity_enhances_product_aesthetics_and_emotion.

Zátonyi, M. (2011). Arte y creación: los caminos de la estética (2a ed.). Buenos Aires: Capital Intelectual S.A.

Zátonyi, M. (2002). Una Estética del arte y el diseño de imagen y sonido (5a ed.). Buenos Aires: Técnica CP-67.

Zátonyi, M. (2016). Aportes a la Estética (2a ed.). Buenos Aires: La marca editora.

Žižek, S. El sublime objeto de la ideología, Siglo XXI, 2a ed., México, 2001 (1ª ed., 1992).

Zwier, J., Blok, V., Lemmens P., (2016) Phenomenology and the Empirical Turn: A Phenomenological Analysis of Postphenomenology. Philos. Technol. (2016) (29) (pp.313-333).

Abstract: From the Occult to the Legible in the Design of the Aesthetics of GM Concept Cars in the United States between 1945 and 1965 is qualitative approach research that studies the praxis of designers from the characterization of their doing, thinking and product to make legible how the design of the aesthetics of the object is produced and reflect on the agency of the designers in relation to its context of operation. Framed in the thematic line of Form and Materiality, this thesis combines empirical material and phenomena such as operations, ideas, people, contexts, ideologies that describe different entry points to the conception of the aesthetics of the object to reveal its multidimensionality. 
The anchor of this research is the praxis for the design of the aesthetics of the object in a case study whose space-time cutoff offers the possibility of deconstruction not only of factors for operations - products, but also the relational and performative nature of this intentional act. design from the institutional perspective. The Concept cars in their material manifestation in the model series between 1945 and 1965 offer heterogeneities and continuities that serve to contrast the adequacy between the conception of their narratives and the message of the automobile image in its fictional expression and identity value. We consider that the findings of this research are relevant to reflect on the skills of the designer to merge in an expression called to shape a series of contents that constitute messages that connect with the sensitivity of people and with this the social responsibility of the act of design is noticed of the aesthetics of the object.

Keywords: design - aesthetics - relational - performative - praxis - designer.

Resumo: Do oculto ao legível não-design da estética da GM Concept Cars nos Estados Unidos entre 1945 e 1965 é uma pesquisa de abordagem qualitativa que estuda a práxis dos designers desde a caracterização de sua fabricação, pensamento e produto até que seja legível, como o design da estética do objeto foi produzido e refletido na agência dos designers em relação ao seu contexto de atuação. Enquadrada na linha temática Forma e Materialidade, esta tese combina material empírico e fenômenos como operações, ideias, pessoas, contextos, ideologias que revelam diferentes pontos de entrada para a concepção estética do objeto para revelar sua diversidade. Uma âncora desta investigação é uma prática para o desenho da estética do objeto em um estudo de caso cujo recorte espaço-temporal oferece a possibilidade de desconstruir não só os fatores de operações - produtos, mas também o caráter relacional e performativo dessa intencionalidade. Os Concept Cars em seu material de manifestação em uma série de modelos entre 1945 e 1965 oferecem heterogeneidades e continuidades que servem para contrastar a adequação entre a concepção de suas narrativas e a mensagem da imagem do automóvel em sua expressão fictícia e valor de identidade. Considerar que os achados desta pesquisa são relevantes para refletir sobre as habilidades do designer para fusão em uma expressão denominada como moldar uma série de conteúdos que constituem mensagens que se conectam com a sensibilidade das pessoas e com a responsabilidade social do design o objeto.

Palavras chave: design - estética - relacional - performativa - práxis - designer.

[Las traducciones de los abstracts fueron supervisadas por el autor de cada artículo] 